Does intercropping have a future in China? Insights from a case study in Gansu Province

Yu Hong 


\section{Thesis committee}

\section{Promotor}

Prof. Dr E.H. Bulte

Professor of Development Economics

Wageningen University \& Research

\section{Co-promotors}

Dr N.B.M. Heerink

Associate professor, Development Economics Group

Wageningen University \& Research

Dr W. van der Werf

Associate professor, Centre for Crop Systems Analysis

Wageningen University \& Research

\section{Other members}

Prof. Dr M.K. van Ittersum, Wageningen University \& Research

Prof. Dr S. Feng, Nanjing Agricultural University, P.R. China

Dr X. Zhu, Wageningen University \& Research

Dr T. Feike, Julius Kühn-Institut, Kleinmachnow, Germany

This research was conducted under the auspices of the Wageningen School of Social Sciences (WASS) 
Does intercropping have a future in China? Insights from a case study in

\title{
Gansu Province
}

\author{
Yu Hong
}

\author{
Thesis \\ submitted in fulfilment of the requirement for the degree of doctor \\ at Wageningen University \\ by the authority of the Rector Magnificus, \\ Prof. Dr A.P.J Mol, \\ in the presence of the \\ Thesis Committee appointed by the Academic Board \\ to be defended in public \\ on Monday 2 July 2018 \\ at 1.30 p.m. in the Aula.
}


Yu Hong

Does intercropping have a future in China? Insights from a case study in Gansu Province, 189 pages.

$\mathrm{PhD}$ thesis, Wageningen University, Wageningen, the Netherlands (2018)

With references, with summary in English

ISBN: 978-94-6343-779-0

DOI: https://doi.org/10.18174/450672 


\section{Table of Contents}

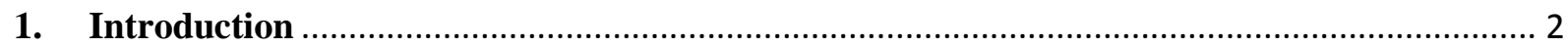

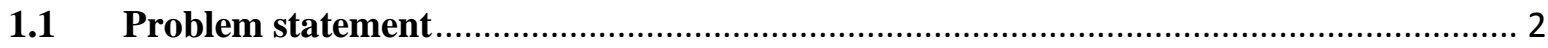

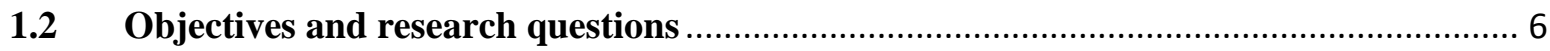

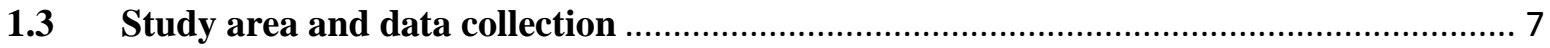

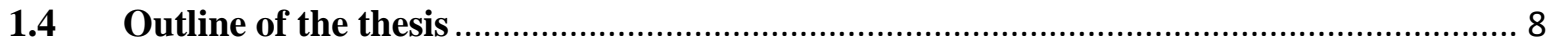

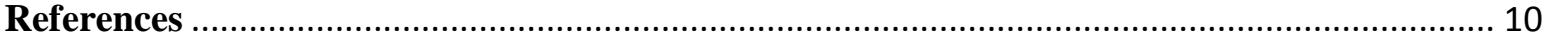

2. Intercropping and agroforestry in China-Current state and trends ........................................... 15

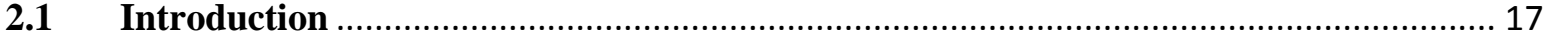

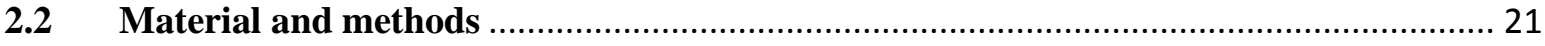

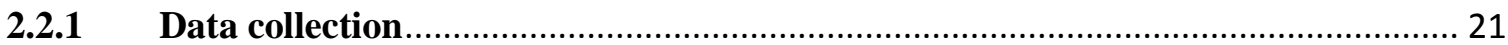

2.2.2 Intercropping and agroforestry land classification .......................................... 24

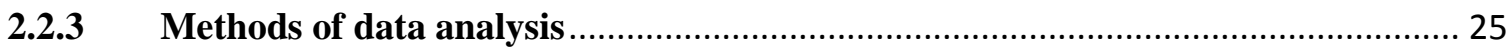

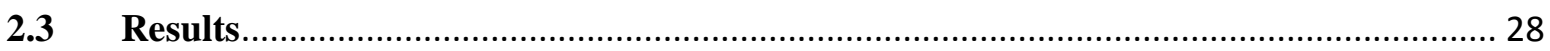

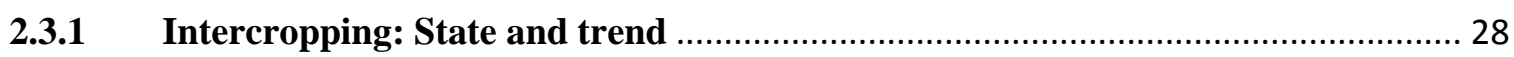

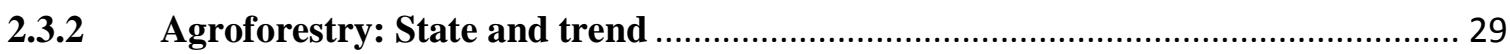

2.3.3 Mixed cultivation systems: State, trend and crop combinations............................ 31

2.3.4 Explorative analysis of occurrence of intercropping ............................................. 36

2.3.5 Explorative analysis of occurrence of mixed cultivation........................................ 38

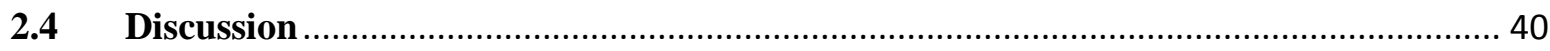

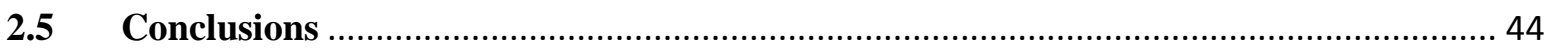

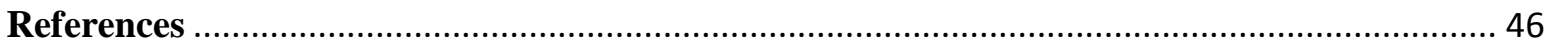

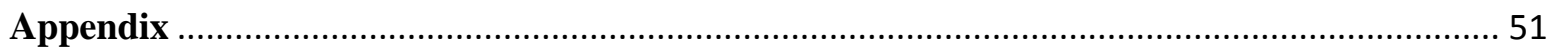

3. The contribution of intercropping to the technical efficiency of smallholder farming: a case

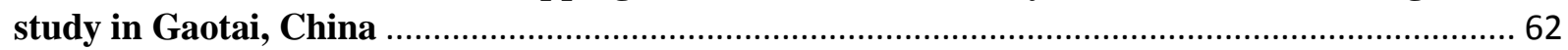

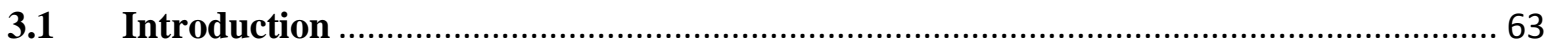

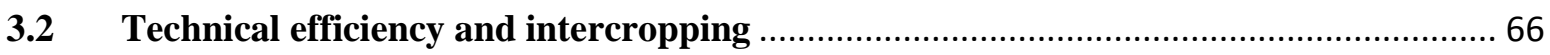

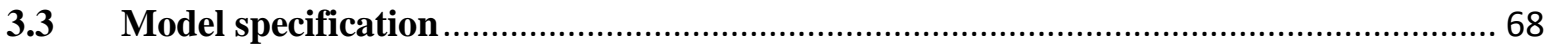

3.3.1 Technical efficiency and frontier production function............................................ 68

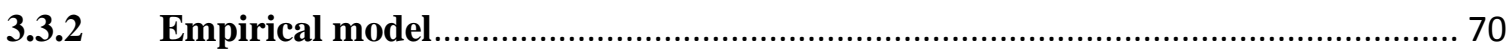

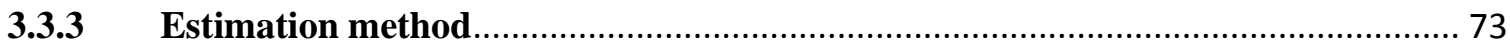

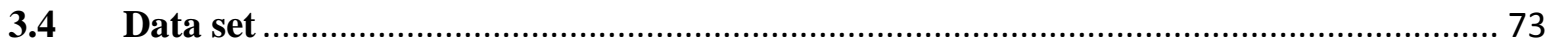

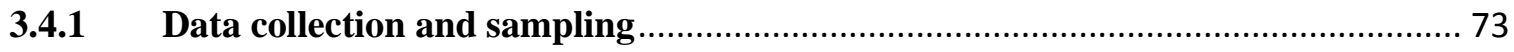

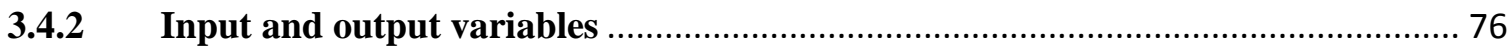

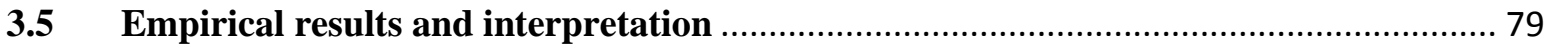




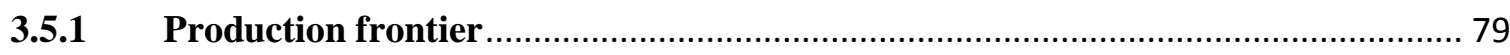

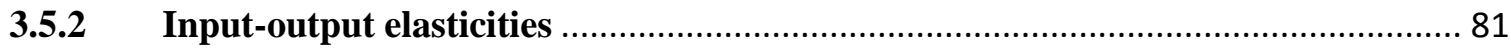

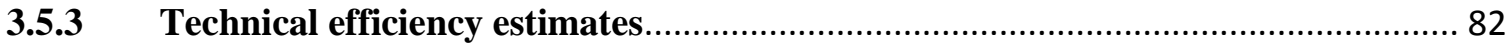

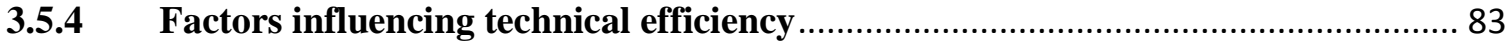

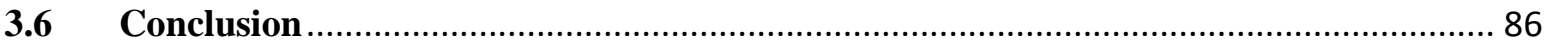

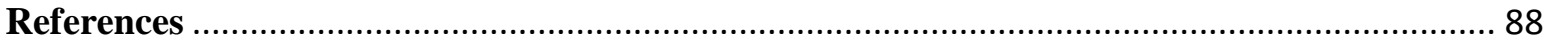

4. Socio-economic factors influencing the adoption of intercropping - Evidence from northwest China

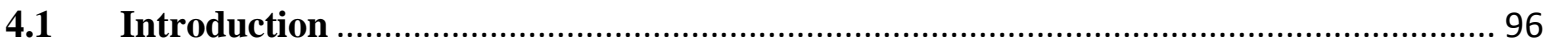

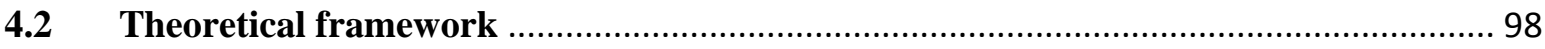

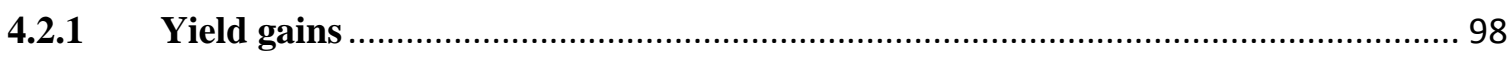

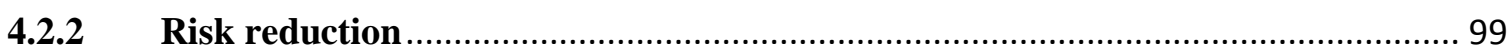

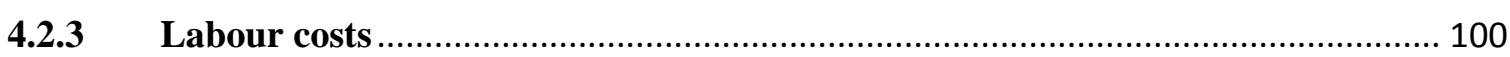

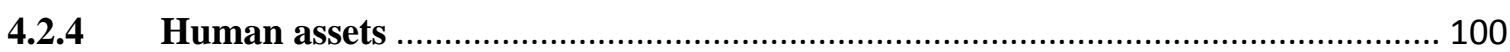

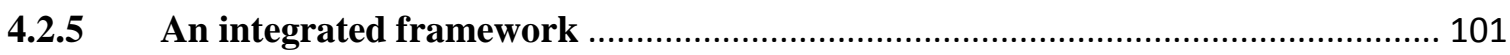

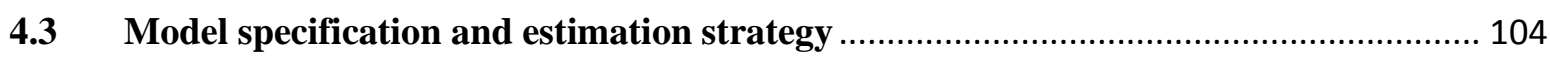

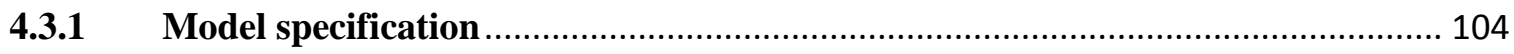

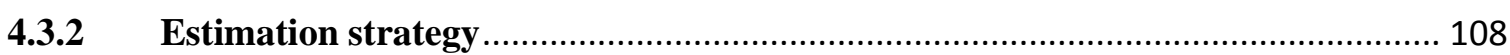

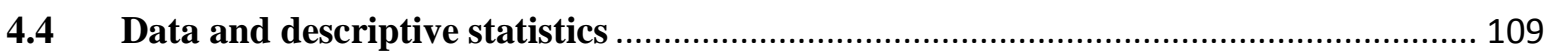

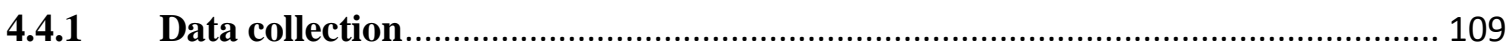

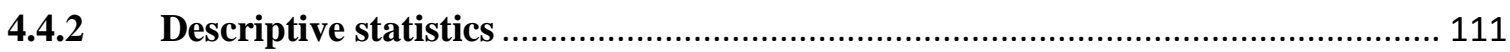

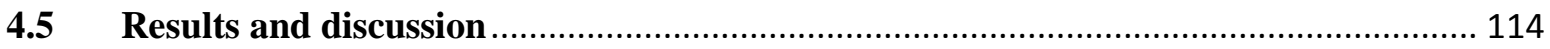

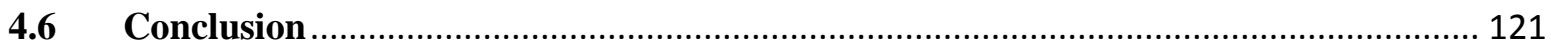

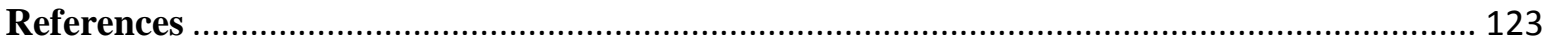

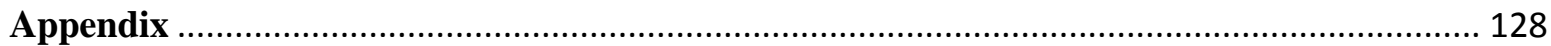

5. The future of intercropping under growing resource scarcity and declining grain prices in

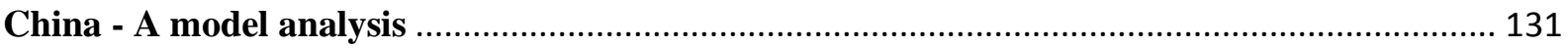

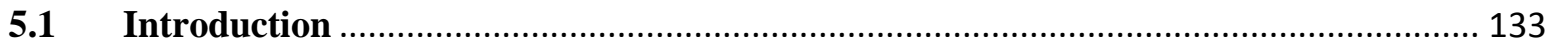

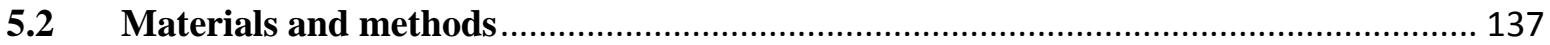

5.2.1 Study area and data collection ........................................................................ 137

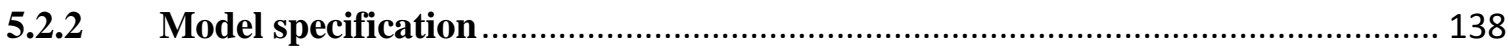

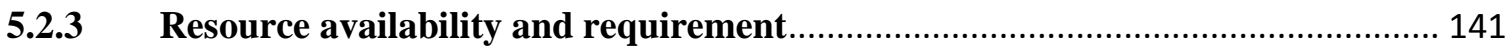

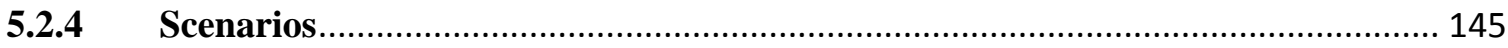

5.2.5 Uncertainty analysis on the value of LER ...................................................... 146

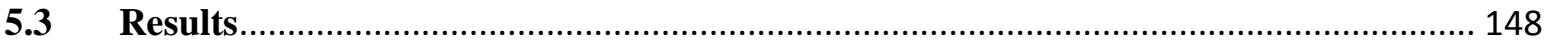

5.3.1 Scenario analysis and sensitivity analysis............................................................. 148 


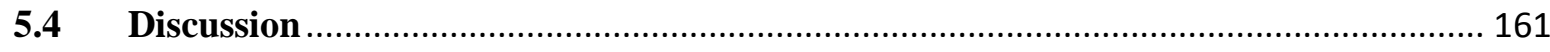

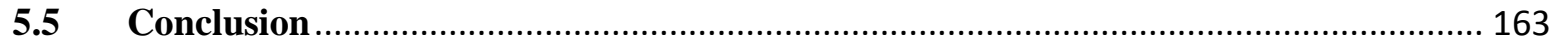

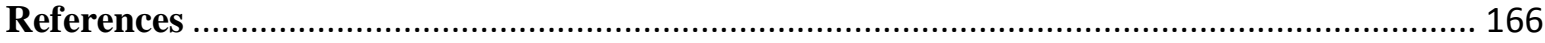

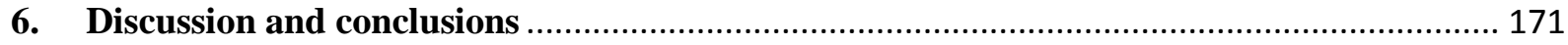

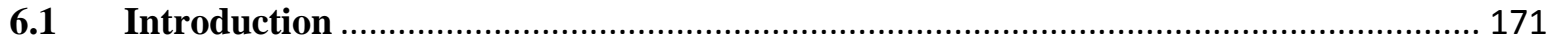

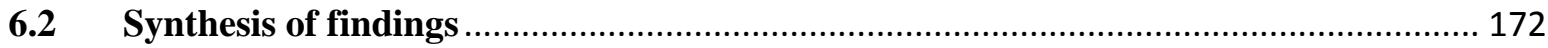

6.2.1 Intercropping is practiced on a small proportion of the land but has not declined

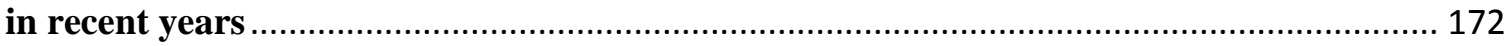

6.2.2 Intercropping improves the technical efficiency of small-scale farming ............. 173

6.2.3 Socio-economic factors related to the use of intercropping …............................. 173

6.2.4 Water and labor scarcity and maize price stress intercropping and its future ... 174

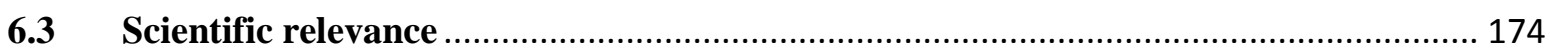

6.3.1 Does agricultural mechanization reduce the use of intercropping?...................... 174

6.3.2 Is intercropping feasible when farm size increases? ............................................ 176

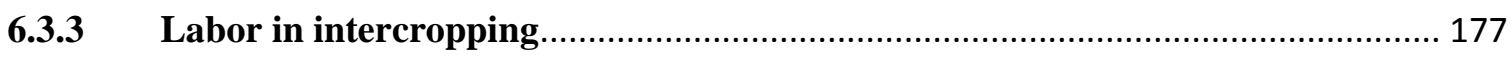

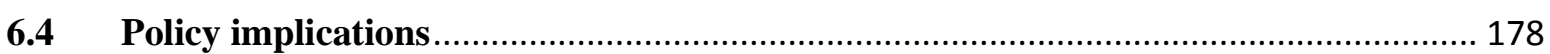

6.5 Limitations and recommendations for future study .................................................. 179

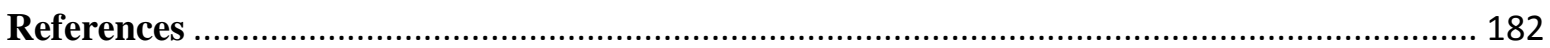

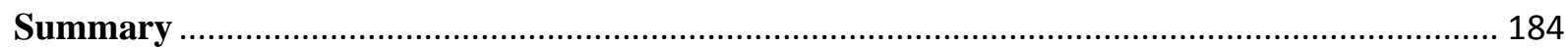

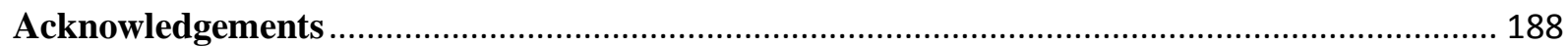




\section{Chapter 1}

\section{General introduction}




\section{Introduction}

\subsection{Problem statement}

It is projected that by 2050, the global human population will exceed 9 billion (Gerland et al., 2014; FAO, 2017) and more than 2 billion people will be suffering from food insecurity (World Bank, 2007). Meanwhile, agricultural land continues to decrease in area due to urban land expansion (d'Amour et al., 2017) and desertification or encroachment by human settlements (Weinzettel et al., 2013). To satisfy the food demand for a growing population continues to be an important concern and challenge for the world (United Nations, 2012; Von Grebmer et al., 2016). China is not an exception. Although the annual population growth rate in China has slowed to $0.49 \%$ in 2013 , the population is still expected to grow by an additional 60 million in the next 15 years (Lu et al., 2015). Urbanization and increasing wealth, together with the large population and changing dietary preferences are expected to be drivers for a higher food demand in the coming two decades (Kearney, 2010). Growing demand for food will place increased pressure on agricultural production in China.

Given its very limited land resources ( $8 \%$ of the world total, 1/3 of the global average per capita) and water resources (1/4 of the global average, per capita), further growth of China's food production may require agricultural intensification through introduction of new technologies (e.g. genetic improvement) and intensified land management. However, the current system of agricultural production, in particular sole-cropping systems, rely too much on intensive and unsustainable use of mineral fertilizers, pesticides and irrigation water (Norse and Ju, 2015; Wang et al., 2015). This results in severe environment consequences as manifested through deterioration in the quality of land (e.g. land degradation) and water (Lu et al., 2015). Thus, sustainable intensification of agriculture is required to produce more yield 
per unit cultivated land whilst limiting environmental repercussions (Bommarco et al., 2013; Geertsema et al., 2016).

Intercropping is the cultivation of two or more crop species simultaneously in the same field (Vandermeer, 1989). Intercropping could play an essential role in the sustainable intensification (Knörzer et al., 2009; Martin-Guay et al., 2018). As an ancient and traditional cropping system, intercropping is still applied in large parts of Africa and in Middle and South America (Francis, 1986; Vandermeer, 1989; Li et al., 2013). In China, intercropping has been practiced for over 1000 years and is still widespread (Knörzer et al., 2009).

Intercropping generally produces more yield per unit of land than sole cropping (Zhang and Li, 2003; Yu et al., 2015) and reduces the risk of crop failure (Horwith, 1985; Lithourgidis et al., 2011). These advantages mainly arise from complementary patterns of resource uptake (light, water and nutrients) between crop species, better nutrient cycling, and through suppression of pests, weeds and diseases (Vandermeer, 1989). Intercropping also has the potential to counteract resource degradation (Lichtfouse, 2009; Feike et al., 2012). It can contribute to increases in soil carbon due to increased root biomass input, and it can increase organic soil nitrogen as a result of better nitrogen cycling (Cong et al., 2015).

Intercrops, however, are more complicated to manage than single crops and mechanization is often not available for intercrops. Therefore, intercropping is usually labor intensive (Lithourgidis et al., 2011; Feike et al., 2012). There is substantial and on-going labor migration to the cities in China, making labor scarce in the rural areas (Wang et al., 2016). The opportunity cost of labor is increasing. This development likely affects the feasibility and profitability of intercropping to households and a shift from intercropping to mono-cropping has been reported in the North China Plain (Feike et al., 2012). Conventional wheat/maize intercropping decreased in the Heihe River Basin in Gansu province (Northwest China) 
during the past decade in response to growing water scarcity (Shi et al., 2014). In other parts of China, however, opposite trends are also observed. In Hebei province (North China), farmers in some villages have recently integrated watermelon as an intercropped species into the traditional wheat/maize double cropping system (Huang et al., 2015). In Wuwei city in Gansu Province, maize-pea intercropping has recently replaced the traditional wheat-maize intercropping system (Mao et al., 2012).

While intercropping continues to be practiced in China, official statistics on sown areas in China do not distinguish single crops from intercrops. There is therefore no official record of intercropping. The available scientific literature presents only scattered information on the prevalence of intercropping in China. Moreover, some reports in the literature are outdated and several of them are based on expert judgement without further underpinning from land use records or surveys. So what is the prevalence of intercropping in current China? What are major trends of intercropping in China? And what are main factors related to the popularity of intercropping? These questions are far from answered.

Efficiency increase is a key driver of productivity growth in agriculture, as it raises productivity without increasing the resource base or developing new technologies. Intercropping is generally considered to have a high efficiency of resource use (Lithourgidis et al., 2011). In particular, high levels of land use efficiency have been found for intercropping systems (Yu et al., 2015; Himmelstein et al., 2017; Martin-Guay et al., 2018). However, high land use efficiency may be obtained at the expense of the efficiency with which other inputs, such as nutrients and water, are used (Huang et al., 2015). Besides, studies on resources use efficiency of intercropping from eco-physiological perspective often concentrate on singleinput, e.g. water, light and nutrients, and mostly based on experiments. There is little knowledge on the overall resource use efficiency of intercropping and its role in farm efficiency. 
Differences in agro-ecological conditions may explain regional variation in intercropping practices across China, but it is not known how socio-economic factors may influence the use or non-use of intercropping. In particular, it is important to know which factors farmers, as the primary decision makers, take into account when making decisions on crop choice.

Arable land is scarce in China and its area is declining due to industrialization, urbanization and agricultural restructuring. Agricultural land loss was especially rapid from 1999 to 2007, due to the government-stimulated conversion of marginal croplands into forest and grassland (Qu et al., 2011). In 2016, around 43\% of population lived in rural areas, while arable land per capita of the rural population was less than 1 ha. ${ }^{1}$ The use of water for industrial purposes and domestic consumption is increasingly reducing the amount of water available for agriculture in China (Qu et al., 2011; Dalin et al., 2015). Thus, while China has almost attained grain selfsufficiency (rice, wheat and maize) (NBSC, 2016; Huang and Yang, 2017), food production still faces the challenges of scarcity of land and water resources. Furthermore, recent increases in rural labor wages have significantly increased the cost of food production (Huang and Yang, 2017). Given the high land use efficiency and agro-ecological advantages, intercropping may make a positive contribution to Chinese food self-sufficiency, food security and sustainability in the future. However it is unknown how farmers would utilize this practice to fulfill their objectives, e.g. food self-sufficiency at the household level and enhancing incomes, and more importantly, would they continue using intercropping and/or innovate the system when socio-economic and agro-climatic conditions change.

While much research is being conducted on the eco-physiology of intercropping, a socioeconomic analysis is critically needed to determine why farmers adopt intercropping or not and why they shift from one production system to another.

\footnotetext{
${ }^{1}$ http://www.stats.gov.cn/tjsj/zxfb/201702/t20170228_1467424.html (in Chinese, accessed 11.03.2018)
} 


\subsection{Objectives and research questions}

The general objective of this study is to obtain a better understanding of farmers' decisions on intercropping in China.

\section{Research questions}

To reach this objective, this study will address the following four main research questions, each of which will cover one research chapter in the thesis.

1. What is the current state of intercropping in China, and what are the major trends? (Chapter 2)

2. What is the contribution of intercropping to the technical efficiency of small-scale farming in northwest China? (Chapter 3)

3. What factors and constraints affect farmers' adoption of intercropping in northwest China? (Chapter 4)

4. What is the future of intercropping under growing resource scarcity and changing grain prices in northwest China? (Chapter 5) 


\subsection{Study area and data collection}

The data that we used to deal with the first research question is part of a national database from the 'Rural Fixed Observation Points Survey’ (RFOPS) which is carried out by the Research Centre for Rural Economy (RCRE) of the Ministry of Agriculture. ${ }^{2}$ In the May June 2014 RFOPS, questions related to intercropping were added to the village leader questionnaire in six of the 30 provinces in China. In consultation with the RCRE, we selected six provinces that represent different agro-ecological and socio-economic conditions prevailing throughout China and where the quality of the RFOPS data is known to be relatively good. These provinces are: Liaoning province in the northeast, Hebei province in the north, Shaanxi province in the northwest, Anhui province in the east, Fujian province in the southeast, and Yunnan province in the southwest. The number of village leaders interviewed in these six provinces was 68 . These villages account for $19 \%$ of the 360 villages that are surveyed through the RFOPS.

The information used to address other three research questions were generated in a farm household survey that was carried out in the Heihe River Basin. During the period August November 2014, well-trained survey teams from Northwest Agricultural and Forestry University (NWAFU) in Yangling, Shaanxi Province, and the University of the Chinese Academy of Sciences (UCAS) in Beijing conducted a survey in the Heihe River Basin in Gansu province and Inner-Mongolia. Data were collected on use of inputs and outputs in agricultural production, consumption and expenditure, and farmers' attitude towards water policy.

The data that we use to deal with research questions 2-4 is obtained from a sub-sample of the Heihe river survey in Gaotai County, Zhangye City, Gansu Province. Zhangye City is an oasis

\footnotetext{
${ }^{2}$ Detailed information of this survey is offered in data collection section (Section 2.2) of chapter 2.
} 
located midstream of the Heihe River. The annual precipitation is $89-283 \mathrm{~mm}$, with 70 to $90 \%$ concentrated in the period July to September, while evaporation is about $1700 \mathrm{~mm}$ per year (Zhang, 2007), resulting in a desert climate type. Due to the availability of irrigation water from the Heihe River, the flat land and abundant sunshine, the area has become a major grain (seed) and vegetable (seed) base in Gansu Province (Luo et al., 2005; Zhang et al., 2013). The Gaotai County region, between $98^{\circ} 57^{\prime}-100^{\circ} 06^{\prime} \mathrm{E}, 39^{\circ} 03^{\prime}-39^{\circ} 59^{\prime} \mathrm{N}$, is one of the six administrative counties in Zhangye City. Wheat and maize are the main staple food crops, while soybean, cotton, rapeseed and seed crops (e.g. seed maize and seed melon) are grown as cash crops. Wheat intercropped with maize and cash crops (e.g. cumin and watermelon) intercropped with maize are important intercropping systems in the region.

\subsection{Outline of the thesis}

The thesis contains six chapters: a general introduction (Chapter 1), four research chapters (Chapter 2 to 5), and a general discussion (Chapter 6). Research chapters are divided into two main parts. The first part presents an overview of state and trends of intercropping in China (chapter 2). The second part focuses on the intercropping in small-scale farming, using a case study on household decision-making in Gaotai County, Gansu Province.

Chapter 2 documents the prevalence of intercropping systems in China, and explores factors related to share of land under intercropping at village level. We collected land use data in 68 villages in 6 different provinces through a survey that was added in 2014 to the annual Rural Fixed Observation Points Survey (RFOPS). We asked village leaders not only about the cropping practices and land use in their villages in 2014, but also about changes compared to 2009. Answers to these questions enabled us to document land use regarding intercropping and make comparisons between 2009 and 2014.We also perform an exploratory regression 
analysis of major factors (rural labor, agricultural machinery and farm size) related to the share of land under intercropping.

Chapter 3 examines whether the use of intercropping has positive or negative effect on the overall technical efficiency of the surveyed farms. We apply stochastic frontier analysis (Kumbhakar and Lovell, 2003) to detailed survey data collected among 360 farms in Gaotai County, Gansu Province in 2014. A one-step procedure is used to estimate technical efficiency scores from a translog production frontier. The resulting farm-specific technical efficiency scores are regressed on a series of factors that may potentially affect technical efficiency, including the proportion of land under intercropping.

Chapter 4 studies socio-economic determinants of adoption of intercropping systems at farm/household level. We apply multiple regression analysis to examine explanatory factors related to traditional and new types of intercropping systems. Dependent variables are area and/or share of land under intercrop(s), independent variables are a series of household assets, household characteristics, and market conditions (credit, machinery services and off-farm opportunities, etc.), based on developed theoretical framework. The same data set of 360 farm households in Gaotai County is used in this chapter.

Chapter 5 explores the future of intercropping under growing resource scarcity and declining grain prices using Gaotai county, Gansu Province as a case study. We developed a mathematical programming model at village level to identify which crop practices will be included in the optimal land use and assess the consequences of resource constraints and labor and output prices for the gross margin of an average village. We analyze the optimal land use under different constraints in relation to the actual land use to answer the question whether intercropping has a future in this region or not. 
Chapter 6 synthesizes the results of the above chapters. It discusses the policy implications and presents recommendations for future research.

\section{References}

Bommarco, R., Kleijn, D., \& Potts, S.G. (2013). Ecological Intensification: Harnessing Ecosystem Services for Food Security. Trends in Ecology \& Evolution, 28(4), 230-238. doi: 10.1016/j.tree.2012.10.012

Cong, W., Hoffland, E., Li, L., Six, J., Sun, J., Bao, X., et al. (2015). Intercropping Enhances Soil Carbon and Nitrogen. Global Change Biology, 21(4), 1715-1726.

d'Amour, C.B., Reitsma, F., Baiocchi, G., Barthel, S., Güneralp, B., Erb, K.-H., et al. (2017). Future Urban Land Expansion and Implications for Global Croplands. Proceedings of the National Academy of Sciences, 114(34), 8939-8944.

Dalin, C., Qiu, H., Hanasaki, N., Mauzerall, D.L., \& Rodriguez-Iturbe, I. (2015). Balancing Water Resource Conservation and Food Security in China. Proceedings of the National Academy of Sciences, 112(15), 4588-4593.

FAO. (2017). The Future of Food and Agriculture: Trends and Challenges. Rome: Food and Agriculture Organization of the United Nations.

Feike, T., Doluschitz, R., Chen, Q., Graeff-Hönninger, S., \& Claupein, W. (2012). How to Overcome the Slow Death of Intercropping in the North China Plain. Sustainability, 4(10), 2550-2565.

Francis, C.A. (1986). Multiple Cropping Systems. New York: Macmillan Publishing Company. Geertsema, W., Rossing, W.A., Landis, D.A., Bianchi, F.J., Rijn, P.C., Schaminée, J.H., et al. (2016). Actionable Knowledge for Ecological Intensification of Agriculture. Frontiers in Ecology and the Environment, 14(4), 209-216.

Gerland, P., Raftery, A.E., Ševčíková, H., Li, N., Gu, D., Spoorenberg, T., et al. (2014). World Population Stabilization Unlikely This Century. Science, 346(6206), 234-237.

Himmelstein, J., Ares, A., Gallagher, D., \& Myers, J. (2017). A Meta-Analysis of Intercropping in Africa: Impacts on Crop Yield, Farmer Income, and Integrated Pest Management Effects. International Journal of Agricultural Sustainability, 15(1), 1-10. 
Horwith, B. (1985). A Role for Intercropping in Modern Agriculture. Bioscience, 35(5), 286291.

Huang, C., Liu, Q., Heerink, N., Stomph, T., Li, B., Liu, R., et al. (2015). Economic Performance and Sustainability of a Novel Intercropping System on the North China Plain. PloS One, 10(8), e0135518.

Huang, J., \& Yang, G. (2017). Understanding Recent Challenges and New Food Policy in China. Global Food Security, 12(Supplement C), 119-126. doi: https://doi.org/10.1016/i.gfs.2016.10.002

Kearney, J. (2010). Food Consumption Trends and Drivers. Philosophical transactions of the royal society B: biological sciences, 365(1554), 2793-2807.

Knörzer, H., Graeff-Hönninger, S., Guo, B., Wang, P., \& Claupein, W. (2009). The Rediscovery of Intercropping in China: A Traditional Cropping System for Future Chinese Agriculture - a Review. In E. Lichtfouse (Ed.), Climate Change, Intercropping, Pest Control and Beneficial, Microorganisms (pp. 13-44). Dordrecht: Springer Netherlands.

Kumbhakar, S.C., \& Lovell, C.K. (2003). Stochastic Frontier Analysis. Cambridge: Cambridge University Press.

Li, L., Zhang, L., \& Zhang, F. (2013). Crop Mixtures and the Mechanisms of Overyielding. In S. Levin (Ed.), Encyclopedia of Biodiversity (pp. 382-395). Waltham: Academic Press. Lichtfouse, E. (2009). Sustainable Agriculture Reviews: Climate Change, Intercropping, Pest Control and Beneficial Microorganisms (Vol. 2). Dordrecht Springer Netherlands. Lithourgidis, A., Dordas, C., Damalas, C., \& Vlachostergios, D. (2011). Annual Intercrops: An Alternative Pathway for Sustainable Agriculture. Australian journal of crop science, 5(4), 396-410.

Lithourgidis, A., Dordas, C., Damalas, C., \& Vlachostergios, D. (2011). Annual Intercrops: An Alternative Pathway for Sustainable Agriculture. Australian journal of crop science, 5(4), 396.

Lu, Y., Jenkins, A., Ferrier, R.C., Bailey, M., Gordon, I.J., Song, S., et al. (2015). Addressing China's Grand Challenge of Achieving Food Security While Ensuring Environmental Sustainability. Science Advances, 1(1), e1400039. 
Luo, F., Qi, S., \& Xiao, H. (2005). Landscape Change and Sandy Desertification in Arid Areas: A Case Study in the Zhangye Region of Gansu Province, China. Environmental Geology, 49(1), 90-97.

Mao, L., Zhang, L., Li, W., van der Werf, W., Sun, J., Spiertz, H., et al. (2012). Yield Advantage and Water Saving in Maize/Pea Intercrop. Field Crops Research, 138, 11-20.

Martin-Guay, M.-O., Paquette, A., Dupras, J., \& Rivest, D. (2018). The New Green Revolution: Sustainable Intensification of Agriculture by Intercropping. Science of the Total Environment, 615, 767-772.

NBSC. (2016). 11.03.2018, from http://www.stats.gov.cn/tjsj/sjid/201603/t20160304 1326842.html (in Chinese)

Norse, D., \& Ju, X. (2015). Environmental Costs of China's Food Security. Agriculture, Ecosystems \& Environment, 209, 5-14.

Qu, F., Kuyvenhoven, A., Shi, X., \& Heerink, N. (2011). Sustainable Natural Resource Use in Rural China: Recent Trends and Policies. China Economic Review, 22(4), 444-460.

Shi, M., Wang, X., Yang, H., \& Wang, T. (2014). Pricing or Quota? A Solution to Water Scarcity in Oasis Regions in China: A Case Study in the Heihe River Basin. Sustainability, 6(11), 7601-7620.

United Nations. (2012). The Zero Hunger Challenge: Transforming Our Food Systems to Transform Our World Retrieved from http://www.un.org/en/zerohunger/challenge.shtml

Vandermeer, J.H. (1989). The Ecology of Intercropping. Cambridge: Cambridge University Press.

Von Grebmer, K., Bernstein, J., Nabarro, D., Prasai, N., Amin, S., Yohannes, Y., et al. (2016). 2016 Global Hunger Index: Getting to Zero Hunger. Washington, D,C: Intl Food Policy Res Inst.

Wang, X., Yamauchi, F., Otsuka, K., \& Huang, J. (2016). Wage Growth, Landholding, and Mechanization in Chinese Agriculture. World Development, 86, 30-45. doi: 10.1016/j.worlddev.2016.05.002

Wang, Z., Zhao, X., Wu, P., He, J., Chen, X., Gao, Y., et al. (2015). Radiation Interception and Utilization by Wheat/Maize Strip Intercropping Systems. Agricultural and Forest Meteorology, 204, 58-66. doi: 10.1016/j.agrformet.2015.02.004 
Weinzettel, J., Hertwich, E.G., Peters, G.P., Steen-Olsen, K., \& Galli, A. (2013). Affluence Drives the Global Displacement of Land Use. Global Environmental Change, 23(2), 433-438. doi: https://doi.org/10.1016/i.gloenvcha.2012.12.010

World Bank. (2007). World Development Report 2008 : Agriculture for Development. Washington, D,C: World Bank Group.

Yu, Y., Stomph, T.-J., Makowski, D., \& van der Werf, W. (2015). Temporal Niche Differentiation Increases the Land Equivalent Ratio of Annual Intercrops: A MetaAnalysis. Field Crops Research, 184, 133-144.

Zhang, F., \& Li, L. (2003). Using Competitive and Facilitative Interactions in Intercropping Systems Enhances Crop Productivity and Nutrient-Use Efficiency. Plant and Soil, 248(1-2), 305-312.

Zhang, J. (2007). Barriers to Water Markets in the Heihe River Basin in Northwest China. Agricultural Water Management, 87(1), 32-40.

Zhang, L., Heerink, N., Dries, L., \& Shi, X. (2013). Water Users Associations and Irrigation Water Productivity in Northern China. Ecological Economics, 95, 128-136. 


\section{Chapter 2}

Intercropping and agroforestry in China

- Current state and trends 


\section{Intercropping and agroforestry in China - Current state and trends ${ }^{3}$}

\section{Abstract}

Intercropping and agroforestry are mixed plant species cultivation systems that can potentially reduce pressure on land and water resources by generating higher crop yields and by increasing resource use efficiencies through exploitation of complementarities between species. While it is frequently claimed that mixed cultivation systems remain popular in Chinese agriculture, there are also reports that it is in decline. Little quantitative evidence is available on the prevalence of intercropping and agroforestry. Therefore, we conducted a village-level survey in 68 villages across six provinces in China in 2014 to document the prevalence of these mixed species cultivation systems in 2009 and 2014. We found that intercropping was practiced on approximately three percent of the arable land in the surveyed villages, while agroforestry was practiced on approximately one percent of the arable land and one percent of the area of plantation plus forest land. The use of both systems did not significantly change between 2009 and 2014. An explorative village-level analysis of factors associated with mixed species cultivation practices reveals a significant positive association with labour availability, and a smaller, but mostly significant, negative association with agricultural machinery power. These survey results provide the first systematically collected quantitative evidence on the current use and trend of mixed cultivation systems in China. The collected evidence indicates that these systems are currently used on a small proportion of the land, but have not declined in recent

\footnotetext{
${ }^{3}$ This chapter has been published as: Hong, Y., Heerink, N., Jin, S., Berentsen, P., Zhang, L., \& van der Werf, W. 2017. Intercropping and agroforestry in China - Current state and trends. Agriculture Ecosystems \& Environment, 244, 52-61.
} 
years. Intercropping continues to provide pathways for ecological intensification of agricultural food production.

Keywords: Intercropping; Agroforestry; Mixed cultivation systems; Arable land; Labour availability 


\subsection{Introduction}

Worldwide, agriculture is nowadays dominated by sole crops, i.e. one crop species in one field. However, mixed cultivation systems consisting of two or more annual crop species (intercrops) or a mixture of crops and trees (agroforestry) in a single field are also in use (Li et al., 2013). ${ }^{4}$ Intercropping has been practiced for thousands of years in China (Lichtfouse, 2009) and other parts of the world (Francis, 1986; Lithourgidis et al., 2011). It is practiced in particular by smallscale traditional farmers aiming to sustain food production and diversify income (Li et al., 2013; Huang et al., 2015). In recent decades, researchers in several disciplines have shown an increasing interest in these traditional cropping systems, because of their potential to generate higher yields and counteract resource degradation (Vandermeer, 1989; Feike et al., 2012; Gou et al., 2017).

Intercropping is the simultaneous cultivation of two or more crop species in the same field (Vandermeer, 1989; Lithourgidis et al., 2011). As plant species differ in temporal and spatial patterns of resource acquisition, an intercrop can often capture the available growth resources such as light, water and nutrients more completely than a single species (Yu et al., 2015). In addition, intercropping reduces the severity of pests and diseases (Andow, 1991; Trenbath, 1993; Zhu et al., 2000). Furthermore, productivity tends to be more stable in intercrops than in sole crop yields due to differences in species responses to adverse weather conditions or to pest and disease outbreaks, in combination with compensatory growth responses of companion species if one species in an intercrop is affected by averse abiotic or biotic factors (Horwith, 1985).

However, intercrops are more complicated to manage than single crops and mechanisation is often not available for intercrops. Therefore, intercropping is usually labour intensive (Shaxson

\footnotetext{
${ }^{4}$ See detailed definition of cropping system in Table A2.1.
} 
and Tauer, 1992; Knörzer et al., 2009; Lithourgidis et al., 2011; Feike et al., 2012). This may reduce the use of intercropping when opportunity costs of agricultural labour increase due to rising off-farm wages, as has been observed in the North China Plain (Feike et al., 2012). Conventional wheat/maize intercropping decreased in the Heihe River Basin in Gansu province (Northwest China) during the past decade in response to growing water scarcity (Shi et al., 2014). In other parts of China, however, different trends are observed. In the North China Plain, farmers in some villages have recently integrated watermelon as an intercropped species into the traditional wheat/maize double cropping system (Huang et al., 2015). In Wuwei city in Gansu Province, maize-pea intercropping has recently replaced the traditional wheat-maize intercropping system (Mao et al., 2012).

While intercropping continues to be practiced in China, official statistics on sown areas in China do not distinguish single crops from intercrops. There is therefore no official record of intercropping. The available scientific literature presents only scattered information on the prevalence of intercropping in China (see Table A2.2 for a detailed overview). Moreover, some reports in the literature are outdated and several of them are based on expert judgement without further underpinning from land use records or surveys. Tong (1994) claims that one third of the total arable land is under multiple cropping (mostly in the form of intercropping) in China. Li (2001, p. 51) claims that 34 million ha of the arable land in China (i.e. ca. 27 percent) is intercropped, and Zou and $\mathrm{Li}$ (2002) state that 33 million ha of arable land in China (i.e. ca. 25 percent) was intercropped in the 1990s. Zhang and Li (2003) cite the figure from Tong while Li et al. (2007) state that over 28 million ha of China's annually sown area (i.e. ca. 18 percent) is intercropped. These reports on the state of intercropping range from $18 \%$ to around $33 \%$, but Feike et al. (2012), based on field visits and expert judgement, estimated that intercropping is practiced on only 5 percent of the arable land of the North China Plain, the "breadbasket" of China. 
There is even less information regarding the prevalence of agroforestry systems in China. Agroforestry is a land use system in which woody perennials are grown in association with agricultural crops or pastures, and in which there are both ecological and economic interactions between trees and the other components (Nair, 1985). Many different agroforestry systems are practised in China (Zhu et al., 1991). In the North China Plain paulownia trees (Paulownia elongata) are intercropped with wheat or bean to enhance the suitability of the micro climate for wheat and bean, while poplar (Populus tomentosa) is intercropped with cereals or cotton (Zou and Sanford Jr, 1990). In Xingjiang province, cotton (Gossypium hirsutum) is recently grown in tree stands of newly planted stands of jujube (Zizyphus jujube) (Wang et al., 2016). This system should be regarded as transitional, as it may no longer be feasible to intercrop cotton in the tree stands as the tree grow larger. Such agroforestry is a form of opportunity cropping underneath trees as long as the trees are young and their resource capture is still small (Wang et al., 2016). The understory crop will be omitted as the trees grow taller and competition from the trees becomes too strong. Combining trees and crops in the same field protects arable land against wind and water erosion and it can improve the soil nutrient balance (Zou and Sanford Jr, 1990; Wang and Shogren, 1992; Yin and Hyde, 2000). Understories of annual crops in apricot (Prunus armeniaca) stands in Liaoning province produce additional crop output and revenue from the apricot stand without a significant decrease in apricot yield (Bai et al., 2016). Compared to sole annual crops, systems with trees better conserve the soil. In the Loess Plateau region, immature fruit trees and annual crops are a widely applied agroforestry system that aims at reducing soil erosion and water loss, and increases economic benefits as a result of fruit production (Gao et al., 2013).

Given the rapid increase of labor wages and use of machinery in Chinese agriculture (Ji et al., 2012; Wang et al., 2016), and the lack of reliable data on the prevalence of intercropping and agroforestry practices, the objectives of this study are 1) to present evidence-based estimates of 
the current state of mixed cultivation systems, i.e. intercropping and agroforestry, in China and their trends in recent years, and 2) to explore factors at the village level that influence the areas under mixed cultivation systems. We collected land use data in 68 villages in 6 different provinces through a survey that was added in 2014 to the annual Rural Fixed Observation Points Survey (RFOPS) carried out by the Research Centre for Rural Economy (RCRE) of the Ministry of Agriculture. We asked village leaders not only about the current cropping practices and land use in their villages in 2014, but also about changes compared to 2009. We also perform an exploratory regression analysis of major factors related to the area under mixed cultivation, combining our village-level data with household-level data for the same villages derived from the RFOPS.

The remainder of the paper is structured as follows. Section 2.2 describes the materials and methods. The results are presented in Section 2.3. Section 2.4 discusses the results, and Section 2.5 elaborates the major conclusions. 


\subsection{Material and methods}

\subsubsection{Data collection}

The 'Rural Fixed Observation Points Survey' (RFOPS) is a longitudinal survey that aims to collect rural socio-economic information on the same households and villages through time. It started in 1986 and covers around 23,000 households in 360 villages located in 30 provinces in mainland China, excluding Tibet (Gustafsson et al., 2014). A stratified random sampling approach is used (Yao, 2011). ${ }^{5}$

The RFOPS carries out annual surveys among households and village leaders to collect basic information such as land utilization, labor inputs, agricultural production, income, and expenditures (Xu et al., 2012; Gustafsson et al., 2014). Enumerators assist households to complete questionnaires, and the interviewed households are revisited annually. Village leaders are interviewed annually, too. As a part of their jobs, they use accounting books to record agricultural production activities, land use and labor inputs in their villages. In particular, they keep records of the main cultivated crops and their cultivated areas. The area belonging to intercropping and agroforestry ${ }^{6}$ practices is included in the recordings, but there is no standard procedure to assign this area to specific crops. Available documentation ${ }^{7}$ states that the area of a crop in an intercropping system should be recorded as its relative area, but does not give an explicit explanation about how relative areas should be calculated.

\footnotetext{
${ }^{5}$ Provinces were divided into plain, hilly and mountainous regions, and within these regions low-, middle- and high-income counties were distinguished. Within each region, representative counties, having average characteristics of their income group, were selected and within each county one representative village was chosen for the survey. Within each village, between $10 \%$ and $20 \%$ of the households were then randomly selected (Gustafsson et al., 2014). If a household cannot be traced due to immigration, death or family division, a similar household in the village is generally selected to fill the vacancy (Yi et al., 2015). Likewise, when a village drops out, because it has been annexed by a nearby city or for other reasons, it is replaced by another village with similar characteristics (Benjamin et al., 2005; Yao, 2011).

${ }^{6}$ In the RFOPS questionnaire, intercropping is defined as more than one species of crop growing at the same or partially overlapping time on a specific plot; agroforestry is defined as combination of trees and arable (annual) crops on the same plot.
}

${ }^{7}$ http://www.docin.com/p-152484799.html (in Chinese, accessed 16.09.15) 
In the May - June 2014 RFOPS, questions related to intercropping and agroforestry were added to the village leader questionnaire in six of the 30 provinces. ${ }^{8}$ In consultation with the RCRE, we selected six provinces that represent different agro-ecological and socio-economic conditions prevailing throughout China and where the quality of the RFOPS data is known to be relatively good. These provinces are: Liaoning province in the northeast, Hebei province in the north, Shaanxi province in the northwest, Anhui province in the east, Fujian province in the southeast, and Yunnan province in the southwest (Figure 2.1). The number of village leaders interviewed in these six provinces was 68 . These villages account for $19 \%$ of the 360 villages that are surveyed through the RFOPS.

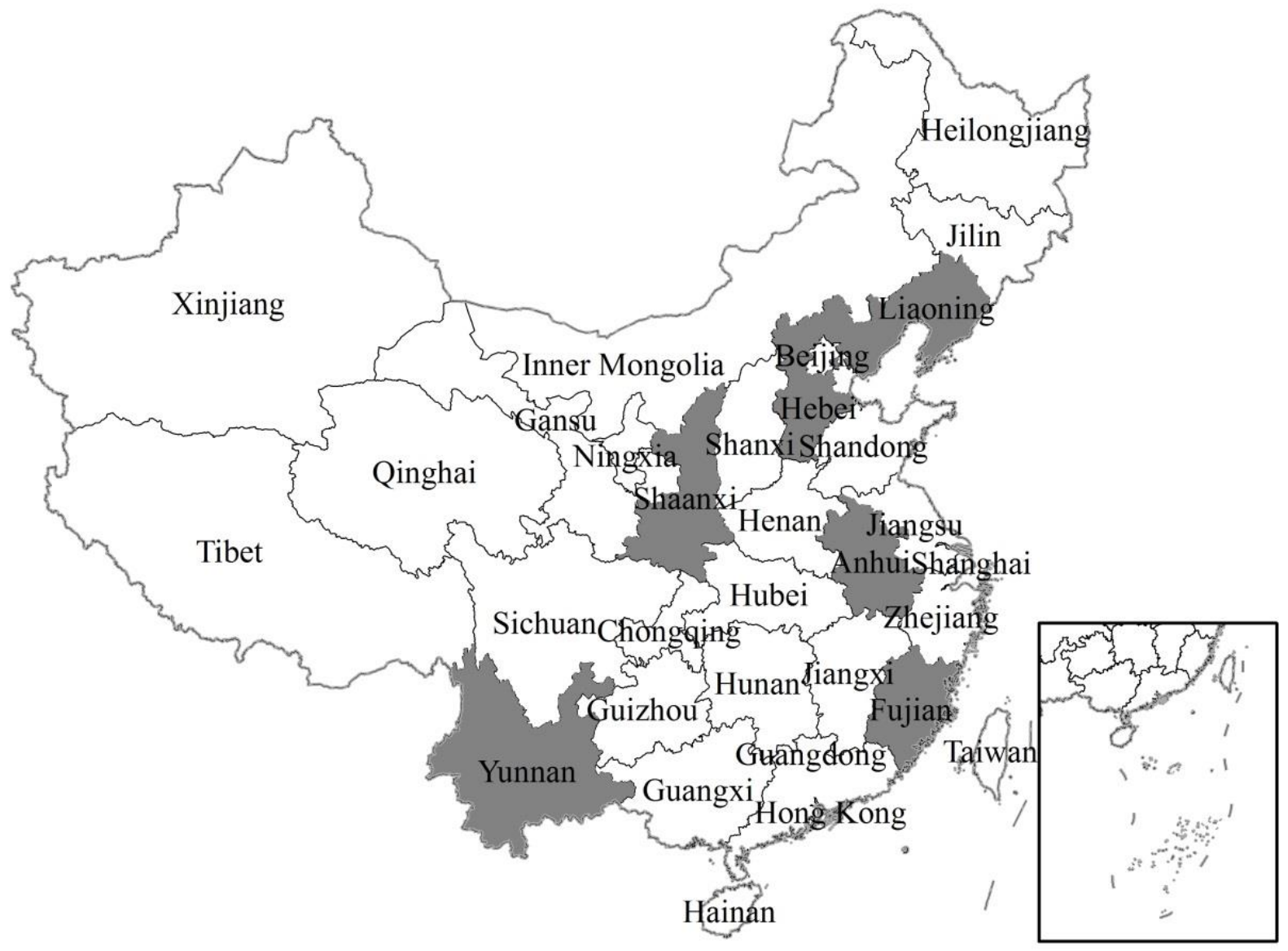

Figure 2.1 Map of China with the surveyed provinces shown in grey

\footnotetext{
${ }^{8}$ Due to financial and other limitations, it was not possible to do the additional village leaders survey in all 30 provinces where the RCRE survey is held.
} 
The questions for the village leaders that were asked in this six-province additional village-level survey are:

Do farmers in your village practice intercropping or agroforestry in 2014 ?

If yes:

2) How large is the land area under intercropping in 2014? And how large is the land area under agroforestry?

3) What is the change in the area of land under intercropping (if any) as compared to 2009 ? And what is change in the land area under agroforestry (if any) since 2009?

4) What are the most important crop combinations that are grown under mixed cultivation (i.e. intercropping or agroforestry) in 2014 ?

5) What are the changes in the most important mixed cultivation crop combinations (if any) between 2009 and 2014?

We choose a five-year recall period, because the quality of answers decreases with longer recall periods. Given the rapid development of the land rental market in rural China, major changes in cropping patterns (including intercropping) may have occurred during the 5-year period. According to official statistics, $11.3 \%$ of the arable land in China was transferred through the land market in 2009, while $30.4 \%$ of the arable land was transferred in 2014 (NBS, various years). ${ }^{9}$

The answers to survey questions enabled us to estimate the states of intercropping and agroforestry in China in 2014 and their trends during the preceding five years. Moreover, to explore factors related to the use of intercropping in these villages in 2009 and 2014, we combined the data on intercropping and agroforestry with data from a supplementary village leaders survey held later in 2014, which provided household-level information on labor force, machinery and arable land and farmland in the same villages for the same years.

\footnotetext{
${ }^{9}$ Unfortunately, no province-specific data on land renting is available in these statistics.
} 


\subsubsection{Intercropping and agroforestry land classification}

In China, agricultural land is classified into five land use types: arable land, plantation land (also called garden land), forest land, grassland and other land uses (e.g. for aquaculture) (NBS, 2002). ${ }^{10}$ Land under intercropping is classified as arable land, because intercropping takes place only on arable land. Land under agroforestry, however, may be classified under different land use types. Agroforestry practices can take place on arable land, like immature fruit trees combined with maize or soybean on the Loess Plateau. Once the trees start producing fruits, they usually become monoculture fruit tree systems and the land is subsequently classified as plantation land. Other examples of agroforestry systems with land classified as arable land are paulownia (Paulownia elongata) combined with wheat or bean, and poplar (Populus tomentosa) combined with cereal or cotton on the North China Plain. Other agroforestry systems take place on plantation land, like tea (Camellia sinensis) with soybean or sesame in Anhui province. Still others are classified as forest land, like chestnut (Castanea mollissima) with soybean, or rubber (Hevea brasiliensis) with tea in Yunnan province.

${ }^{10}$ See detailed classification of agricultural land use in Table A2.3. 


\subsubsection{Methods of data analysis}

To estimate the current state of intercropping in China, we calculate the share of the arable land under intercropping in the villages that were included in the supplementary survey held in 2014 . We dropped five of the 68 observations because the village leaders reported the area of arable land to be zero or negligible in their villages. Next, we calculated the share of the arable land under intercropping in 2009 for the same 63 villages, and applied t-tests to examine whether the share of land under intercropping had significantly changed between 2009 and 2014. The ttest is a paired two tailed test, with shares of intercropping for 2009 and 2014 in the same village making up the pairs. We applied a similar approach for estimating the current state and recent trend in agroforestry. Because agroforestry can take place on arable land, plantation land and forest land, we took two steps. First, we expressed agroforestry systems on arable land as a share of the total arable land area. Second, we expressed agroforestry systems on plantation and forest land as a share of plantation and forest land. Lastly, we expressed land under mixed cultivation systems (i.e. intercropping and agroforestry) as a share of the farmland area (i.e. arable land, plantation land and forest land). We further used the answer to the fifth question in the supplementary 2014 survey to examine whether the most important crop combinations in intercropping and/or agroforestry remained the same or changed between 2009 and 2014.

Given that the use of agricultural machinery rapidly increased during the period 2009-2014 (NBS, various years), we expected that the shares of land under intercropping and agroforestry would have declined. Moreover, the share arable land transferred through the land market in China increased from $11.3 \%$ in 2009 to $30.4 \%$ in 2014. An increasing share was rented out to private firms and professional cooperatives; in 2014 they contracted 32 percent of the rented arable land (MoA, various years). Most professional cooperatives and enterprises are interested in large-scale farm management based on single crops and use of machinery, and are therefore expected to abandon intercropping and agroforestry practices. 
To explore factors related to the presence of intercropping and mixed cultivation systems ${ }^{11}$ in the sampled villages, we estimated a regression model:

$$
Y_{i}=\beta_{0}+\beta_{1} L_{i}+\beta_{2} M_{i}+\beta_{3} F_{i}+\epsilon_{i}
$$

where:

$Y_{i}=$ Value of the dependent variable (share of arable land under intercropping; share of farmland under mixed cultivation systems) in village $i$.

$L_{i}=$ Average number of laborers per interviewed household in village $i$, Labourers are defined as persons whose age is over 16 years and who are not disabled for manual work.

$M_{i}=\quad$ Average agricultural machinery power (measured in $\mathrm{kW}$ ) per interviewed household in village $i$. Agricultural machinery refers to large, medium and small sized tractors and towing farm machineries, combine harvester and other motor-driven agricultural machines. ${ }^{12}$

$F_{i}=$ Average arable land size (for intercropping) or farmland size (for mixed cultivation systems) in village $\mathrm{i}$.

$\beta_{0}, \beta_{1}, \beta_{2}, \beta_{3}=$ Regression coefficients.

$\varepsilon_{\mathrm{i}}=$ Random disturbance term assumed to be normally distributed with zero mean and constant variance.

The RFOPS database contains information on three main endowments - labor, machinery and land - that are potentially related to the occurrence of intercropping and agroforestry in villages. Intercropping systems are usually labour-intensive and mechanization is often not available for such systems. We therefore expect a positive relation between the presence of mixed cultivation systems with the amount of labour per household and a negative relation with the availability

\footnotetext{
${ }^{11}$ As will be discussed in Section 2.3.2, agroforestry is practiced only on a very small share of the arable land area in our surveyed provinces and is mainly concentrated in one province. We therefore did not do a similar analysis for the presence of agroforestry.

${ }^{12}$ For specific explanation, please see http://www.stats.gov.cn/english/NewsEvents/200802/t20080227_25994.html (accessed at 16.09.2015)
} 
of agricultural machinery. Moreover, mixed cultivation systems are more likely to occur in villages where the pressure on the land is high.

It needs to be stressed that the regression analysis is of an exploratory nature. Given the small sample size, we only examine the degree of association between the share of land under intercropping or mixed cultivation and the right-hand side variables without addressing endogeneity issues such as potential reverse causality.

The dependent variable can take on values ranging between 0 and 1 . There are relatively many zero value observations, but no observations with a value of one in the datasets for the two models. A left-censored Tobit model (Greene, 2003) is therefore applied for estimating the two models. 


\subsection{Results}

\subsubsection{Intercropping: State and trend}

A substantial portion of the villages (11 out of 63 villages in 2009 and 13 in 2014) applied intercropping (Table A2.4). The popularity of intercropping varied considerably between the different provinces (Figure 2.2). The area under intercropping was largest (between $4.7 \%$ and $7.6 \%$ in 2014) in the surveyed villages in Fujian, Yunnan and Shaanxi, and increased in these three provinces between 2009 and 2014. It slightly declined (from an already low level of 0.3\%) in the surveyed villages in Anhui and was absent in the surveyed villages in Hebei and Liaoning in both 2009 and 2014. Overall, the share of arable land under intercropping increased slightly during the five-years period, from $2.3 \%$ of the area in 2009 to $2.7 \%$ in 2014, but the null hypothesis that the mean values are equal was not rejected $(\mathrm{t}(62)=-0.83, \mathrm{p}=0.41)$.

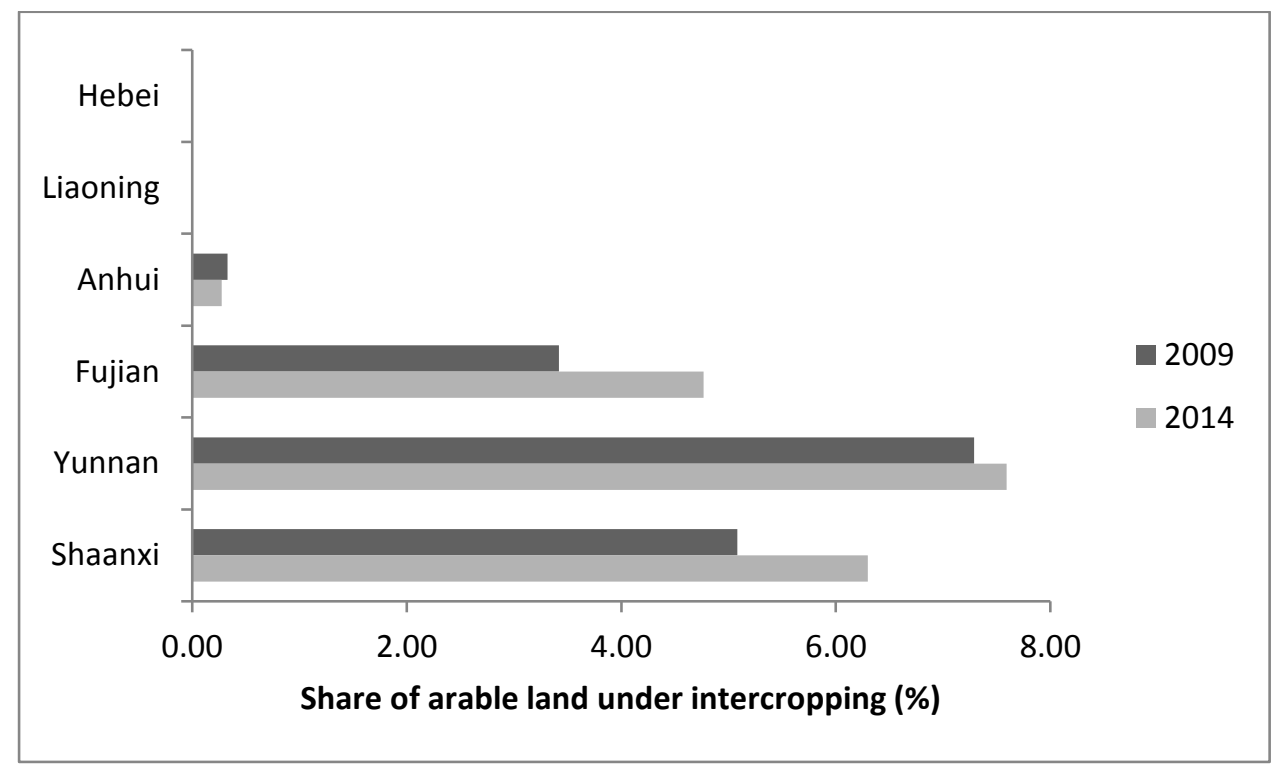

Figure 2.2 Prevalence of intercropping in arable land in surveyed villages, 2009 and 2014 


\subsubsection{Agroforestry: State and trend}

As mentioned above, crop/tree mixtures are planted in land that is classified as arable land, plantation land, or forest land. In four of the six provinces none of the villages reported any arable land under agroforestry (Table A2.5), while in Anhui province only a very small share of the arable land was reported to be used for agroforestry. In Shaanxi province, however, the share of arable land under agroforestry amounted to 6.5 percent in 2009 and 8.3 percent in 2014 (Figure 2.3). In both years, it was larger than the share of arable land under intercropping in Shaanxi. Overall, the share of arable land under agroforestry slightly increased during the fiveyear period from 1.0 percent in 2009 to 1.2 percent in 2014 . This increase is statistically significant at the $5 \%$ level $(\mathrm{t}(62)=-2.26, \mathrm{P}=0.03)$.

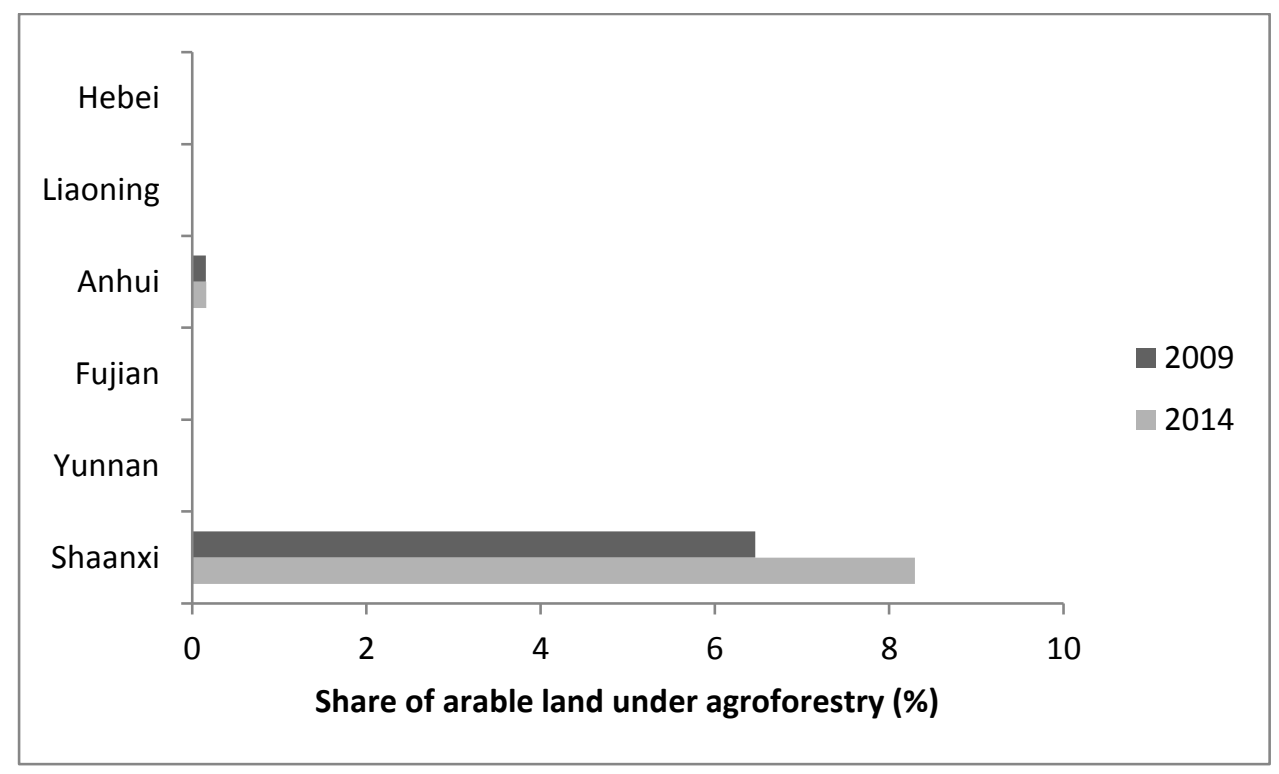

Figure 2.3 Prevalence of agroforestry in arable land in surveyed villages, 2009 and 2014

In two of the six provinces none of the villages reported any plantation or forest land under agroforestry (Table A2.6). In Liaoning province, a very small share of the plantation and forest land was reported to be agroforestry land, while the largest share of land under plantation and forest land was reported from Yunnan province: 2.9 percent in 2009 and 2.6 percent in 2014 (Figure 2.4). Overall, the share of plantation and forest land under forest agroforestry slightly 
increased during the five-year period from 1.1 percent in 2009 to 1.4 percent in 2014. This increase is not statistically significant at the $5 \%$ level $(\mathrm{t}(62)=-0.21, \mathrm{p}=0.83)$.

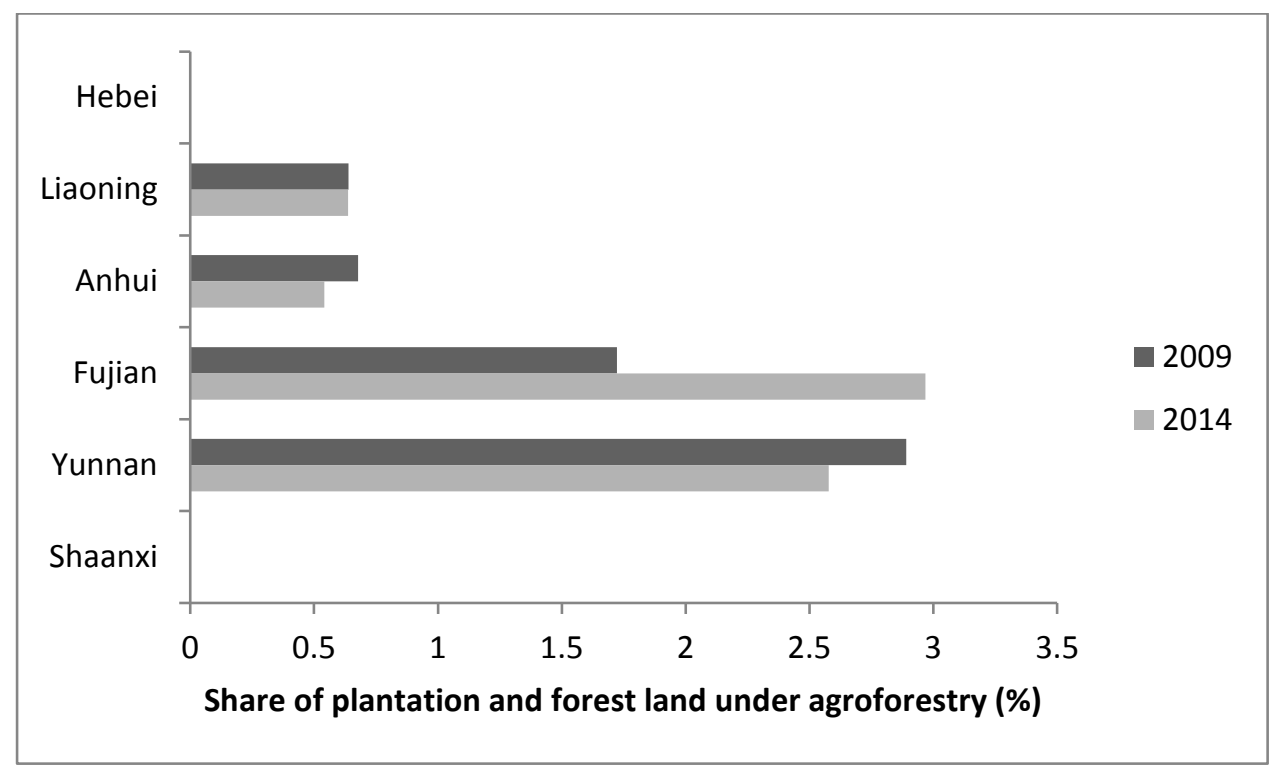

Figure 2.4 Prevalence of agroforestry in plantation and forest land in surveyed villages, 2009 and 2014 


\subsubsection{Mixed cultivation systems: State, trend and crop combinations}

Overall, land under mixed cultivation systems accounted for a small proportion of the farmland (1.8\% in 2009 and $2.1 \%$ in 2014) (Table A2.7). Its prevalence was largest in Yunnan and Shaanxi, and somewhat lower but still notable in Fujian province. It was less than one percent in Liaoning and Anhui and completely absent from the surveyed villages in Hebei province (Figure 2.5). In total, the proportion of farmland under mixed cultivation slightly increased (0.3\%) between 2009 and 2014, but the increase was not statistically significant $(\mathrm{t}(62)=-0.91$, $\mathrm{P}=0.37)$.

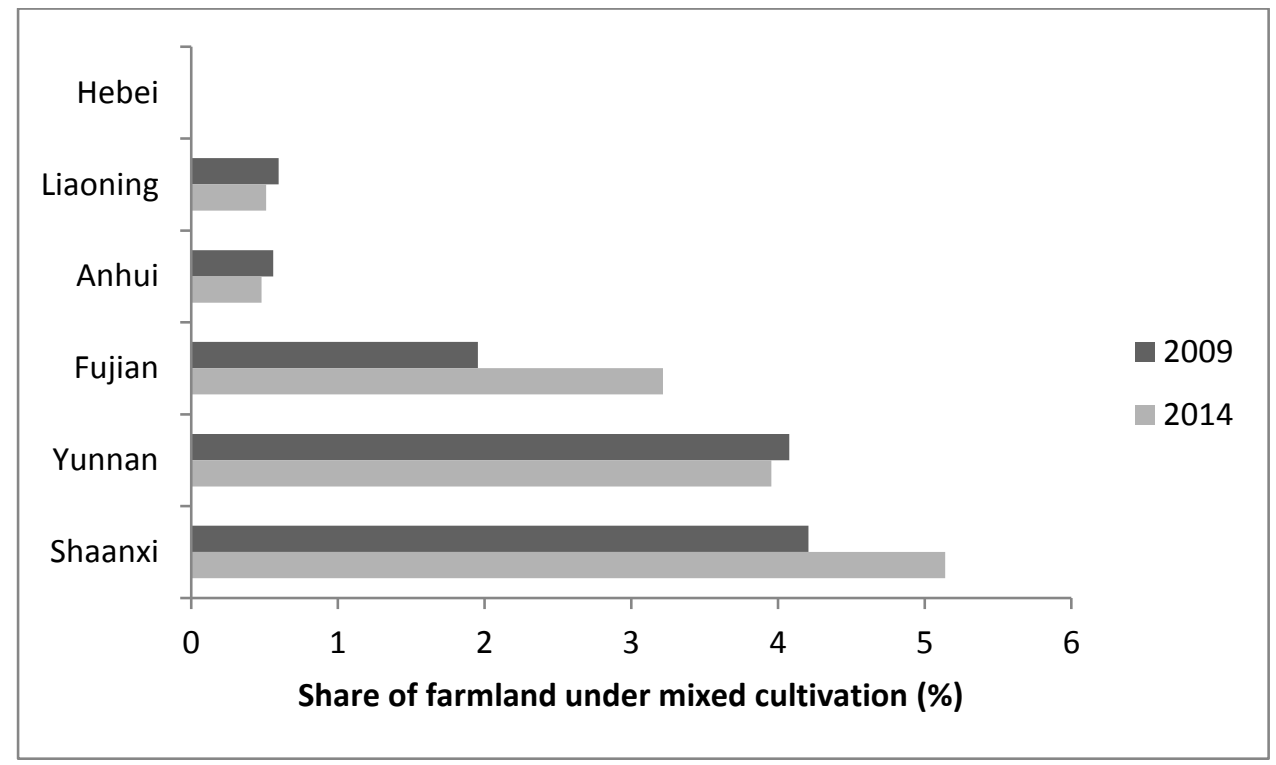

Figure 2.5 Prevalence of mixed cultivation systems in farmland in surveyed villages, 2009 and 2014 


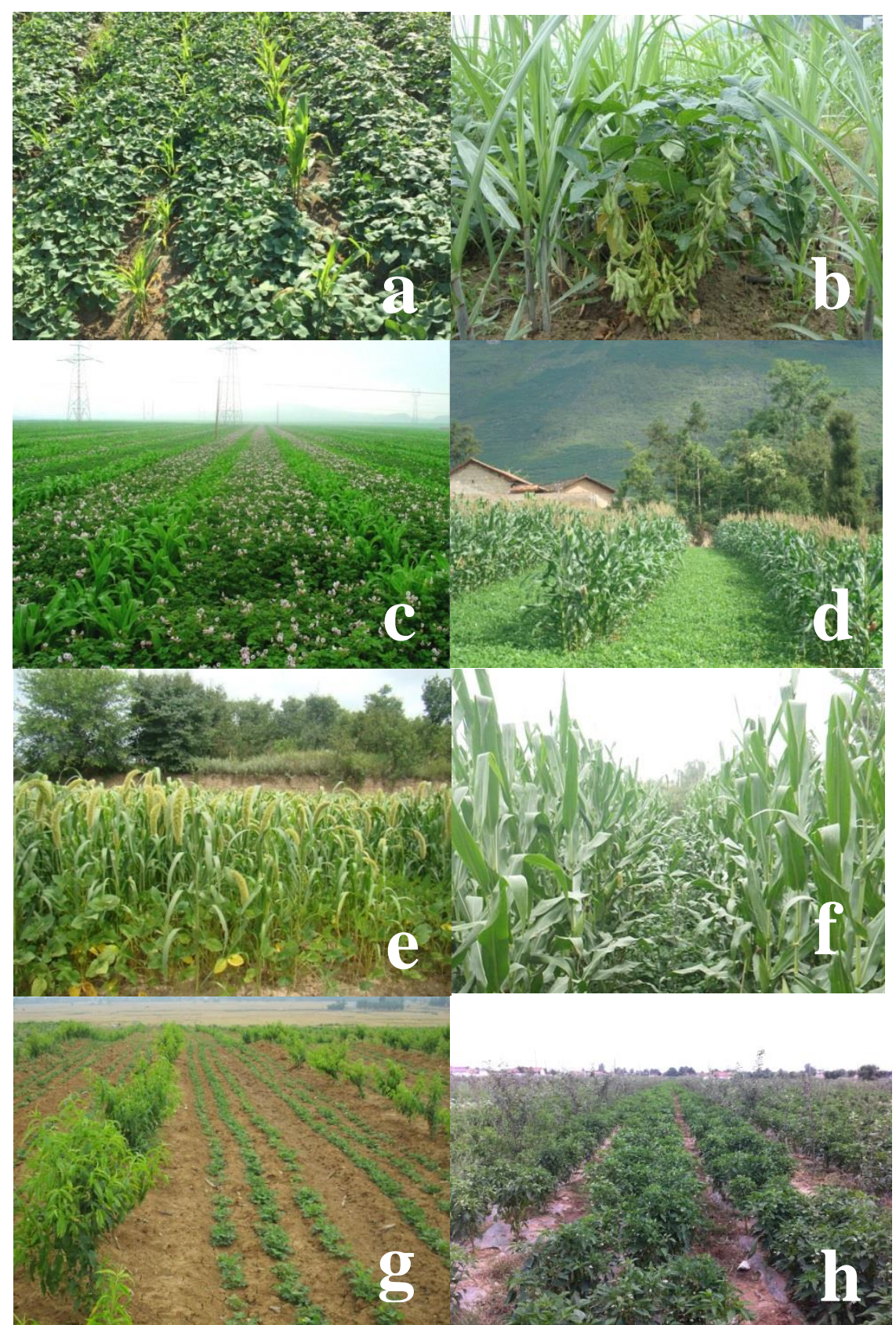

Figure 2.6 (a) maize and sweet potato in Fujian; (b) sugarcane and soybean in Guangxi; (c) (d) maize and potato, maize and peanut in Yunnan; (e) (f) soybean and millet, maize and soybean in Shaanxi; (g) peach and peanut in Anhui; (h) peach and pepper in Shaanxi. Photo credits, (a) (e) (h) Yu Hong; (b) http://www.gxny.gov.cn/guigang/nydt/ggdt/201305/t20130506_327878.html ; (c) Yunnan Agricultural University, Science and Technology Department; (d) http://www.mlpny.gov.cn/ws/mlp/news4827/20110623/999836.shtml; (f) Wopke van der Werf; (g) http://blog.sina.com.cn/s/blog_4dd934560102vxts.html. 
There was a large diversity of species combinations, both in intercropping and agroforestry, in the surveyed villages (Tables 2.1 and 2.2). For intercropping, cereals combined with legumes and legumes combined with potatoes were the most important combinations (Figure 2.6). For agroforestry, fruit trees combined with cereals or legumes were the most important combinations (Figure 2.6). In seven out of the eleven villages with intercropping in 2009 , the most important combinations remained the same between 2009 and 2014 (Table 2.1). Most of the newly observed crop combinations did not include cereals. Agroforestry combinations were quite stable; the main combinations changed in only 2 out of the 13 villages that reported agroforestry practices in 2009 and 2014 (Table 2.2). ${ }^{13}$

${ }^{13}$ For two villages, no information on main agroforestry combinations is available. 
Table 2.1 Main intercropping systems in surveyed villages, 2009 and 2014

\begin{tabular}{|c|c|c|c|}
\hline \multirow[t]{2}{*}{ Province } & \multirow[t]{2}{*}{ Village } & \multicolumn{2}{|c|}{ Most important combinations } \\
\hline & & 2009 & 2014 \\
\hline Anhui & Jinqiao & Sesame/soybean & Sesame/soybean \\
\hline \multirow[t]{2}{*}{ Fujian } & Tangbei & $\begin{array}{l}\text { Peanut/maize, sweet } \\
\text { potato/maize }\end{array}$ & $\begin{array}{l}\text { Peanut/maize, sweet } \\
\text { potato/maize }\end{array}$ \\
\hline & Guihou* & Soybean/sugarcane & $\begin{array}{l}\text { Peanut/sugarcane, } \\
\text { soybean/sugarcane }\end{array}$ \\
\hline \multirow[t]{4}{*}{ Yunnan } & Yunshan & Soybean/potato, peanut/potato & Soybean/potato, peanut/potato \\
\hline & Yaoying* & $\begin{array}{l}\text { Maize/legume, maize } \\
\text { /vegetables, vegetable /legume }\end{array}$ & $\begin{array}{l}\text { Maize/ legume, potato/legume, } \\
\text { maize/potato }\end{array}$ \\
\hline & Jiangxi & Maize /legume & Maize/ legume \\
\hline & Namu* & None & Potato/N.A. \\
\hline \multirow[t]{6}{*}{ Shaanxi } & Fanjia* & None & $\begin{array}{l}\text { Chinese cabbage/N.A., } \\
\text { chili/N.A. }\end{array}$ \\
\hline & Yulinzi & Maize/soybean & Maize/soybean \\
\hline & Qingqiu & N.A. & N.A. \\
\hline & Zhujiaba & $\begin{array}{l}\text { Maize/potato, } \\
\text { Maize/soybean, } \\
\text { Maize/buckwheat, } \\
\text { Maize/vegetable }\end{array}$ & $\begin{array}{l}\text { Maize/potato, } \\
\text { Maize/soybean, } \\
\text { Maize/buckwheat, } \\
\text { Maize/vegetable }\end{array}$ \\
\hline & Fendong & $\begin{array}{l}\text { Potato/soybean, potato/adzuki } \\
\text { bean }\end{array}$ & $\begin{array}{l}\text { Potato/soybean, potato/adzuki } \\
\text { bean }\end{array}$ \\
\hline & Yangshulin & $\begin{array}{l}\text { Wheat/maize, } \\
\text { soybean/maize }\end{array}$ & $\begin{array}{l}\text { Wheat/maize, } \\
\text { soybean/maize }\end{array}$ \\
\hline
\end{tabular}

Source: RFOPS village leader survey, 2014.

*: villages where the most important change of combinations took place.

N.A.: not available. 
Table 2.2 Main agroforestry systems in surveyed villages, 2009 and 2014

\begin{tabular}{|c|c|c|c|}
\hline \multirow[t]{2}{*}{ Province } & \multirow[t]{2}{*}{ Village } & \multicolumn{2}{|c|}{ Most important combinations } \\
\hline & & 2009 & 2014 \\
\hline Liaoning & Huafeng & $\begin{array}{l}\text { Pear/soybean, pear/peanut, } \\
\text { apple/sweet potato }\end{array}$ & $\begin{array}{l}\text { Pear/soybean, pear/peanut, } \\
\text { apple/sweet potato }\end{array}$ \\
\hline \multirow[t]{2}{*}{ Anhui } & Xuying & Peach /peanut & Peach /peanut \\
\hline & Jinqiao & $\begin{array}{l}\text { Soybean/tea, sesame/tea, } \\
\text { peanut/tea }\end{array}$ & $\begin{array}{l}\text { Soybean/tea, sesame/tea, } \\
\text { peanut/tea }\end{array}$ \\
\hline Fujian & Guihou & $\begin{array}{l}\text { Dimocarpus longan/soybean, } \\
\text { litchi/soybean }\end{array}$ & $\begin{array}{l}\text { Dimocarpus longan/soybean, } \\
\text { litchi/soybean }\end{array}$ \\
\hline \multirow[t]{4}{*}{ Yunnan } & Yunshan & Tea/N.A. & Tea/N.A. \\
\hline & Yaoying & $\begin{array}{l}\text { Chestnut/soybean, } \\
\text { peach/soybean }\end{array}$ & $\begin{array}{l}\text { Chestnut/soybean, } \\
\text { peach/soybean }\end{array}$ \\
\hline & Jiangxi & N.A. & N.A. \\
\hline & Namu* & None & $\begin{array}{l}\text { Tea/Macadamia, coffee/ } \\
\text { Macadamia, rubber/tea }\end{array}$ \\
\hline \multirow[t]{8}{*}{ Shaanxi } & Leiyuan & Maize/walnut & Maize/walnut \\
\hline & Baochengzhuang & Soybean/fruit tree & Soybean/fruit tree \\
\hline & Xihu & N.A. & N.A. \\
\hline & Xifurao & Maize/kiwi fruit & Maize/kiwi fruit \\
\hline & Fanjia & $\begin{array}{l}\text { Fruit tree/cereal, fruit } \\
\text { tree/vegetable }\end{array}$ & $\begin{array}{l}\text { Fruit tree/cereal, fruit } \\
\text { tree/vegetable }\end{array}$ \\
\hline & Peizhai & $\begin{array}{l}\text { Apple/wheat, apple/rape } \\
\text { flower }\end{array}$ & $\begin{array}{l}\text { Apple/wheat, apple/rape } \\
\text { flower }\end{array}$ \\
\hline & Shuangmiaoyuan* & $\begin{array}{l}\text { Mulberry/maize, } \\
\text { mulberry/wheat }\end{array}$ & $\begin{array}{l}\text { Mulberry/chilli, } \\
\text { mulberry/soybean, } \\
\text { mulberry/potato }\end{array}$ \\
\hline & Zhujiaba & None & Maize/gingko \\
\hline
\end{tabular}

Source: RFOPS village leader survey, 2014.

*: villages where the most important change of combinations took place.

N.A.: not available. 


\subsubsection{Explorative analysis of occurrence of intercropping}

The average share of arable land under intercropping in the surveyed villages equalled $4.9 \%$ in 2009 and 5.1\% in 2014 (Table A2.8). These percentages are higher than the percentages presented in Tables A2.4. In Table A2.4, the average proportion of land used for intercropping and agroforestry was calculated by cumulating all intercropping area over the sampled villages, and dividing by the total land area as a denominator. As a result, villages with a larger land area contribute more to the calculated mean share than villages with a smaller land area. In the regression analysis, however, the share of intercropping is calculated for each village and then averaged over provinces or the whole sample. Consequently, all villages have an equal weight in the calculated mean, irrespective of the land area of the village. The share of arable land under intercropping ranged among villages from zero to $99.3 \%$. The average number of labourers per household equalled 2.72 in 2009 and 2.63 in 2014. Average agricultural machinery power per household increased from $2.02 \mathrm{KW}$ in 2009 to $2.78 \mathrm{KW}$ in 2014, while the average arable land size, declined from $5.72 \mathrm{mu}^{14}$ in 2009 to $5.50 \mathrm{mu}$ in 2014. Much variation existed in average arable land size across the surveyed villages; it ranged from less than one mu to around $40 \mathrm{mu}$ (Table A2.8).

As expected, the average number of laborers in a household was positively and significantly $(\mathrm{P}<0.05)$ related to the share of land under intercropping in 2009 and in 2014 (Table A2.9). Agricultural machinery power, on the other hand, had a significant negative association $(\mathrm{P}<$ 0.10) with the intercropping land share in 2009, but the estimated coefficient did not differ significantly from zero in 2014. The estimated coefficient for average arable land size did not differ significantly from zero in both years. Dropping this variable did not affect the conclusions drawn for the other two explanatory variables. We ran an additional regression

\footnotetext{
${ }^{14}$ One mu equals $1 / 15$ hectare.
} 
with provincial dummies added to equation (1), but results of the Wald test show that the estimated coefficients of these dummies are not jointly different from zero at $5 \%$ testing level in $2009\left(\mathrm{~F}_{3,57}=1.25, \mathrm{p}=0.301\right)$ and in $2014\left(\mathrm{~F}_{3,57}=1.8, \mathrm{p}=0.156\right)$.

Table 2.3 Estimated marginal effects, share of arable land under intercropping 2009 2014

\begin{tabular}{lrr}
\hline $\begin{array}{l}\text { Independent } \\
\text { variable }\end{array}$ & & \\
\hline $\begin{array}{l}\text { Number of } \\
\text { laborers }\end{array}$ & $(2.08)$ & $0.127 * * *$ \\
& & $(3.22)$ \\
Agricultural & $-0.034 * * *$ & -0.006 \\
machinery & $(-3.60)$ & $(-1.14)$ \\
power & & -0.003 \\
Arable land & -0.003 & $(-0.57)$ \\
\end{tabular}

Marginal effects are calculated as the product of the estimated coefficient and the probability that the conditioning event (= share of arable land under intercropping) is larger than zero (Greene, 1999). Figures in parentheses are asymptotic 't' ratios; *,**,*** represent significance at the $10 \%, 5 \%$ and $1 \%$ level.

The estimated marginal effects (Table 2.3) indicate that the relationship of intercropping with the number of laborers in a household is much stronger than its relationship with agricultural machinery power, especially in year 2014. On average, an increase in the average number of laborers in a household by one is expected to be associated with an increase in the share of arable land under intercropping by $8-13$ percentage points. 


\subsubsection{Explorative analysis of occurrence of mixed cultivation}

The average share of farmland under mixed cultivation in the 63 surveyed villages equaled $3.0 \%$ (Table A2.8). It ranged from 0 to $25 \%$ in 2009 and from 0 to $37 \%$ in 2014 . Average farmland size, i.e. the area of arable, plantation, and forest land, equaled around $26 \mathrm{mu}$ in the surveyed villages. It ranged from almost $0.5 \mathrm{mu}$ in one village to as much as $293 \mathrm{mu}$ in another village in 2014 .

As expected, the average number of laborers in a household was positively related to the share of land under mixed cultivation while average agricultural machinery power was negatively related (Table A2.10). The estimated coefficients differed significantly from zero $(\mathrm{P}<0.10)$ for both variables in 2009 as well as 2014. Average farmland size, however, had no significant association with share of arable land under mixed cultivation. Dropping this variable from the regression equation had little effect on the results for the other variables. We also ran additional regression with provincial dummies added to equation (1). Results of the Wald test show that the estimated coefficients of these dummies are not jointly different from zero at $5 \%$ testing level in $2009\left(\mathrm{~F}_{4,56}=1.39, \mathrm{p}=0.248\right)$ and in $2014\left(\mathrm{~F}_{4,56}=1.45, \mathrm{p}=0.229\right)$. 
Table 2.4 Estimated marginal effects, share of farmland under mixed cultivation

Independent

variable

\begin{tabular}{lrr}
\hline $\begin{array}{l}\text { Number of } \\
\text { laborers }\end{array}$ & $0.030^{* *}$ & $0.041^{* * *}$ \\
& $(2.55)$ & $(3.14)$ \\
& & \\
$\begin{array}{l}\text { Agricultural } \\
\text { machinery } \\
\text { power }\end{array}$ & $-0.006^{* *}$ & $-0.004^{* *}$ \\
& $(-2.39)$ & $(-2.16)$ \\
Farmland & & \\
& -0.000 & -0.000 \\
& $(-1.39)$ & $(-1.03)$
\end{tabular}

Marginal effects are calculated as the product of the estimated coefficient and the probability that the conditioning event (= share of farmland under mixed cultivation) is larger than zero (Greene, 1999). Figures in parentheses are asymptotic ' $\mathrm{t}$ ' ratios; $*, * *, * * *$ represent significance at $10 \%, 5 \%$ and $1 \%$ of testing level.

The estimated marginal effects (Table 2.4) were again larger (in absolute size) for the labor variable than for the machinery variable, particularly in 2014, as was the case for the intercropping model. They indicate that an increase in the average number of laborers in a household by one is associated with an increase of 3.0-4.1 percentage points in the share of farmland under mixed cultivation. An increase in the average availability of agricultural machinery power per household, on the other hand, is associated with a 0.4 - 0.6 percentage points decline in the share of farmland under mixed cultivation. 


\subsection{Discussion}

This paper estimated the state of intercropping and agroforestry in 2014 and their trends during the period 2009-2014 in six provinces in China on the basis of village leader survey data collected in 2014 and five year recall data collected during the same survey, and explored the factors related to the presence of intercropping and mixed cultivation at the village level.

Our results show that intercropping was practiced on $2.3 \%$ and $2.7 \%$ of the arable land in the six surveyed provinces in 2009 and 2014, respectively. Agroforestry on arable land (crop/tree combinations) covered a small portion of the total arable land, $1.0 \%$ in 2009 and $1.2 \%$ in 2014 . Taking into account that agroforestry is also practiced on plantation land and forest land $(1.1 \%$ and $1.4 \%$ ), we find that mixed cultivation systems (i.e. intercropping plus agroforestry) is practiced on $1.8 \%$ and $2.1 \%$ of the total farmland. Our estimated shares of arable land under intercropping are in line with those of Feike et al. (2012), who found that intercropping land accounts for a small proportion of the arable land in the North China Plain. They are, however, much lower than most 'guesstimates' presented in available studies since the 1990s (see Table A2.2).

Secondly, we find that the shares of arable land under intercropping did not change significantly between 2009 and 2014 while Feike et al. (2012) found that intercropping showed a declining trend in the last decades in the North China plain. The difference may be due to a difference in the sampled areas. We furthermore found no changes from 2009 to 2014 in the share of plantation land and forest land under agroforestry, or the share of total farmland under mixed cultivation. These findings contradict our a priori expectation that the share of land under mixed cropping systems would have declined during the period 2009-2014 (see Section 2.2.3). Evidently this finding depends on the quality of the five-year recall data. But we have no reason to assume that village leaders would give up- or downward biased answers about the state of 
mixed cropping systems five years ago. Another possible explanation may be that, although mixed cropping systems were abandoned in some parts of China, new mixed cropping systems with revenues exceeding those of off-farm employment have been developed in other parts. An example of the latter is the integration of watermelon as an intercropped species into the traditional wheat/maize double cropping system in some villages in the North China Plain (Huang et al., 2015).

Thirdly, we find evidence of limited changes between 2009 and 2014 in the most important intercropping and agroforestry combinations in the surveyed villages. In 4 out the 11 villages with intercropping in 2009 and in 2 out of the 13 villages with agroforestry in that same year, the most important combinations had changed in 2014.

It should be noted that some provinces where specific intercropping practices are reported to be popular were not included in this research. This holds in particular for wheat/maize/sweet potato intercropping in Sichuan and Guizhou in southwest China (Meng, 2006; Yan et al., 2010) and wheat/maize intercropping in Gansu in northwest China (Li et al., 1999; Wang et al., 2015; Gou et al., 2016). Six provinces were selected to represent a broad region in different agro-ecological and socio-economic conditions. The specific six provinces were recommended by the RCRE because of the comparatively high quality of the data collection process in these provinces. Data collection on intercropping and agroforestry systems should preferably be integrated into existing data collection systems for rural China, such as the Rural Fixed Observation Point Survey (RFOPS), to obtain a broader regional coverage and thereby further improve the quality of the estimates.

We further find that the average number of laborers in a household is positively related with the presence of intercropping and mixed cultivation systems in 2009 and 2014, and that agricultural machinery power is negatively related with these two systems, albeit not statistically significant 
for intercropping in the year 2014. These findings are consistent with previous research (Knörzer et al., 2009; Feike et al., 2012) showing that intercropping tends to be relatively labour-intensive, while specific machinery for pruning, weeding and harvesting intercropping is usually not available in China. We further find that the marginal effect of labor on the presence of intercropping and mixed cultivation systems has increased between 2009 and 2014 , while the (absolute value of) the marginal effect of machinery power has declined. More research is needed to examine the cause(s) of these striking trends.

The regression analyses of factors related to intercropping and mixed cultivation systems in our study are of an explorative nature. We focus on three potentially important economic factors, while data limitations prohibit the inclusion of agro-ecological conditions, cultural or other factors that may play an important role in household decisions on the adoption of monoculture vs. mixed cultivation systems. For similar reasons, we merely examine associations between dependent and independent variables without addressing potential endogeneity of the dependent variables (prevalence of intercropping and mixed cultivation systems). More systematic data collection on the use of intercropping and agroforestry systems by farm households in China, preferably integrated into existing data collection systems, may also facilitate addressing these limitations of the present study. Our findings indicate that access to farm machinery is driving producers away from intercropping, while availability of farm labor is encouraging this practice. It seems there are some underlying socio-economic factors (as well as agro-ecological factors) influencing the adoption of such practices that could potentially be explored further. Systematic data collection of mixed cropping systems would allow a more rigorous examination of the (socio-economic, agro-ecological and other) factors underlying the use of mixed cropping systems by, for example, clustering the results based on these different classes or regions. In addition, future research in this field would greatly benefit from household surveys that include questions to respondents about their reasons for (non-)adoption of mixed cropping systems. 
Intercropping may be related to ecological or socio-economic conditions that have a geographic gradient across China. Some of the surveyed sites have sufficient natural resources for double cropping, i.e. successively growing two crops within one year. Anhui, Fujian and Hebei have little intercropping because there is sufficient heat resource for double cropping. Intercropping on the other hand may be more popular in parts of Gansu, northwest of Liaoning, where the heat resource is too low for double cropping but more than enough for growing a single crop, such that high yielding relay intercropping systems could be used (Zhang et al., 2007; Yu et al., 2015). Sichuan and Guangxi in southwest China have sufficient heat resource for growing three subsequent crops or two (relay) intercrops in one year. Further work is needed to ascertain the spatial distribution of intercropping in relation to climatic zones and extend the findings reported here. There is also a considerable spread in socio-economic conditions between the surveyed regions, ranging from relatively high income areas in Fujian and Liaoning to poorer regions in Yunnan and Shaanxi (NBS, various years).

Intercropping systems have declined dramatically in developed regions such as the United States and Europe since the 1940s (Horwith, 1985; Machado, 2009). In Europe, agroforestry ${ }^{15}$ has become virtually extinct, existing merely in small regions (Eichhorn et al., 2006; Mosquera-Losada et al., 2012). In less developed regions of Africa, Asia and Latin America, intercropping and agroforestry practices are still reported to be applied widely, playing an important role in agricultural production (Windle, 1988; Vandermeer, 1989; Li et al., 2013). There is however little hard evidence on the current state and trend in recent decades of these mixed cultivation systems in these regions. Our study shows a small but apparently stable role of intercropping and agroforestry over the period 2009-2014 in six provinces in China. More systematic data collection, preferable integrated into existing agricultural data collection

\footnotetext{
${ }^{15}$ Agroforestry practices in these studies are much broader than we defined in our study. Here agroforestry practices include silvoarable, silvopasture, windbreaks etc.
} 
systems, is needed to obtain well-documented insights into the state and trend of intercropping and agroforestry in different parts of the developing world.

\subsection{Conclusions}

Intercropping and agroforestry may contribute to higher yields and higher resource use efficiency, while counteracting resource degradation. The present study shows that intercropping and agroforestry area currently accounts for a small portion of arable land area in the surveyed six provinces in China. Although the evidence is based on only 68 villages located in six provinces, our survey data is the first systematic database for analyzing and estimating the state and trends of intercropping and agroforestry in China. While these systems are currently used on only a small proportion of the land, the collected evidence indicates that their use has not declined in recent years. Intercropping continues to provide pathways for ecological intensification of agricultural food production.

\section{Acknowledgments}

The authors gratefully acknowledge the time and efforts spent by the survey team of the Research Centre for Rural Economy (RCRE) of the Ministry of Agriculture, Beijing, P.R. China in collecting the data that we used for this study. This research was funded by the China Scholarship Council (CSC, grant number: 201206300117) and the Key Sino-Dutch Joint Research Project of NSFC (Grant number: 31210103906). 


\section{Author Contributions}

Yu Hong, Wopke van der Werf and Nico Heerink jointly developed the research methodology, based on an idea by Nico Heerink. Shuqin Jin facilitated data collection and data entry. Yu Hong carried out data analyses. All authors contributed to interpretation of results and writing of the paper.

\section{Conflicts of Interest}

The authors declare that there is no financial/personal interest or belief that could affect their objectivity. 


\section{References}

Andow, D.A. (1991). Vegetational Diversity and Arthropod Population Response. Annual Review of Entomology, 36(1), 561-586.

Andrews, D.J., \& Kassam, A.H. (1975). Importance of Multiple Cropping in Increasing World Food Supplies. Hyderabad, India: International Crops Research Institute for the Semi-arid Tropics.

Bai, W., Sun, Z., Zheng, J., Du, G., Feng, L., Cai, Q., et al. (2016). Mixing Trees and Crops Increases Land and Water Use Efficiencies in a Semi-Arid Area. Agricultural Water Management, 178, 281-290.

Benjamin, D., Brandt, L., \& Giles, J. (2005). The Evolution of Income Inequality in Rural China. Economic Development and Cultural Change, 53(4), 769-824.

Eichhorn, M., Paris, P., Herzog, F., Incoll, L., Liagre, F., Mantzanas, K., et al. (2006). Silvoarable Systems in Europe-Past, Present and Future Prospects. Agroforestry Systems, 67(1), 29-50.

Feike, T., Doluschitz, R., Chen, Q., Graeff-Hönninger, S., \& Claupein, W. (2012). How to Overcome the Slow Death of Intercropping in the North China Plain. Sustainability, $4(10), 2550-2565$.

Francis, C.A. (1986). Multiple Cropping Systems. New York: Macmillan Publishing Company.

Gao, L., Xu, H., Bi, H., Xi, W., Bao, B., Wang, X., et al. (2013). Intercropping Competition between Apple Trees and Crops in Agroforestry Systems on the Loess Plateau of China. PloS One, 8(7), e70739.

Gou, F., van Ittersum, M.K., Wang, G., van der Putten, P.E., \& van der Werf, W. (2016). Yield and Yield Components of Wheat and Maize in Wheat-Maize Intercropping in the Netherlands. European Journal of Agronomy, 76, 17-27.

Gou, F., Yin, W., Hong, Y., van der Werf, W., Chai, Q., Heerink, N., et al. (2017). On Yield Gaps and Yield Gains in Intercropping: Opportunities for Increasing Grain Production in Northwest China. Agricultural Systems, 151, 96-105.

Greene, W. (1999). Marginal Effects in the Censored Regression Model. Economics Letters, 64(1), 43-49.

Greene, W.H. (2003). Econometric Analysis (fifth ed.). New Jersey: Prentice Hall. 
Gustafsson, B., Shi, L., \& Sato, H. (2014). Data for Studying Earnings, the Distribution of Household Income and Poverty in China. China Economic Review, 30, 419-431.

Horwith, B. (1985). A Role for Intercropping in Modern Agriculture. Bioscience, 35(5), 286291.

Huang, C., Liu, Q., Heerink, N., Stomph, T., Li, B., Liu, R., et al. (2015). Economic Performance and Sustainability of a Novel Intercropping System on the North China Plain. PloS One, 10(8), e0135518.

Ji, Y., Yu, X., \& Zhong, F. (2012). Machinery Investment Decision and Off-Farm Employment in Rural China. China Economic Review, 23(1), 71-80.

Knörzer, H., Graeff-Hönninger, S., Guo, B., Wang, P., \& Claupein, W. (2009). The Rediscovery of Intercropping in China: A Traditional Cropping System for Future Chinese Agriculture-a Review Climate Change, Intercropping, Pest Control and Beneficial Microorganisms (pp. 13-44). Dordrecht: Springer.

Li, L., Li, S.-M., Sun, J.-H., Zhou, L.-L., Bao, X.-G., Zhang, H.-G., et al. (2007). Diversity Enhances Agricultural Productivity Via Rhizosphere Phosphorus Facilitation on PhosphorusDeficient Soils. Proceedings of the National Academy of Sciences, 104(27), 1119211196.

Li, L., Yang, S., Li, X., Zhang, F., \& Christie, P. (1999). Interspecific Complementary and Competitive Interactions between Intercropped Maize and Faba Bean. Plant and Soil, 212(2), 105-114.

Li, L., Zhang, L., \& Zhang, F. (2013). Crop Mixtures and the Mechanisms of Overyielding. In S. Levin (Ed.), Encyclopedia of Biodiversity (pp. 382-395). Waltham: Academic Press.

Li, W. (2001). Agro-Ecological Farming Systems in China (Vol. 26). Paris: Taylor \& Francis. Lichtfouse, E. (2009). Sustainable Agriculture Reviews: Climate Change, Intercropping, Pest Control and Beneficial Microorganisms (Vol. 2). Dordrecht Springer Netherlands. Lithourgidis, A., Dordas, C., Damalas, C., \& Vlachostergios, D. (2011). Annual Intercrops: An Alternative Pathway for Sustainable Agriculture. Australian journal of crop science, 5(4), 396.

Machado, S. (2009). Does Intercropping Have a Role in Modern Agriculture? Journal of Soil and Water Conservation, 64(2), 55A-57A.

Mao, L., Zhang, L., Li, W., van der Werf, W., Sun, J., Spiertz, H., et al. (2012). Yield Advantage and Water Saving in Maize/Pea Intercrop. Field Crops Research, 138, 11-20. 
Meng, E.C. (2006). Maize in China: Production Systems, Constraints, and Research Priorities. Mexico: CIMMYT.

MoA. (various years). China Agriculture Yearbook. Beijing. (in Chinese): China Agriculture Press.

Mosquera-Losada, M., Moreno, G., Pardini, A., McAdam, J., Papanastasis, V., Burgess, P., et al. (2012). Past, Present and Future of Agroforestry Systems in Europe. In P. K. R. Nair \& D. Garrity (Eds.), Agroforestry-the Future of Global Land Use (pp. 285-312). Dordrecht: Springer Netherlands.

Nair, P.R. (1985). Classification of Agroforestry Systems. Agroforestry Systems, 3(2), 97-128. NBS. (2002). China Statistical Yearbook. Beijing (in Chinese): National Bureau of Statistics NBS. (2002). Divisions of Administrative Areas and Natural Resources. from

http://www.stats.gov.cn/english/ClassificationsMethods/Definitions/200204/t2002

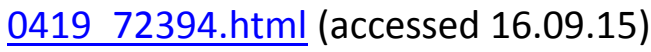

NBS. (2003). China Statistical Yearbook. Beijing (in Chinese): National Bureau of Statistics NBS. (various years). China Statistical Yearbook. Beijing: National Bureau of Statistics. Shaxson, L., \& Tauer, L.W. (1992). Intercropping and Diversity: An Economic Analysis of Cropping Patterns on Smallholder Farms in Malawi. Experimental Agriculture, 28(02), 211-228.

Shi, M., Wang, X., Yang, H., \& Wang, T. (2014). Pricing or Quota? A Solution to Water Scarcity in Oasis Regions in China: A Case Study in the Heihe River Basin. Sustainability, 6(11), 7601-7620.

Tong, P. (1994). Achievements and Perspectives of Tillage and Cropping Systems in China. Cropping System and Cultivation Technology, 4, 1-5. (in Chinese).

Trenbath, B.R. (1993). Intercropping for the Management of Pests and Diseases. Field Crops Research, 34(3-4), 381-405. doi: http://dx.doi.org/10.1016/0378-4290(93)90123-5 Vandermeer, J.H. (1989). The Ecology of Intercropping. Cambridge: Cambridge University Press.

Wang, Q., Han, S., Zhang, L., Zhang, D., van der Werf, W., Evers, J.B., et al. (2016). Density Responses and Spatial Distribution of Cotton Yield and Yield Components in Jujube (Zizyphus Jujube)/Cotton (Gossypium Hirsutum) Agroforestry. European Journal of Agronomy, 79, 58-65. 
Wang, Q., \& Shogren, J.F. (1992). Characteristics of the Crop-Paulownia System in China. Agriculture, Ecosystems \& Environment, 39(3), 145-152.

Wang, X., Yamauchi, F., Otsuka, K., \& Huang, J. (2016). Wage Growth, Landholding, and Mechanization in Chinese Agriculture. World Development, 86, 30-45. doi: 10.1016/j.worlddev.2016.05.002

Wang, Z., Zhao, X., Wu, P., He, J., Chen, X., Gao, Y., et al. (2015). Radiation Interception and Utilization by Wheat/Maize Strip Intercropping Systems. Agricultural and Forest Meteorology, 204, 58-66. doi: 10.1016/j.agrformet.2015.02.004

Windle, P.N. (1988). Enhancing Agriculture in Africa: A Role for Us Development Assistance. Washington, DC: U.S. Congress, Office of Technology Assessment.

Xu, C., Wang, H., \& Shi, Q. (2012). Farmers' Income and Production Responses to Rural Taxation Reform in Three Regions in China. Journal of Agricultural Economics, 63(2), 291-309.

Yan, Y., Gong, W., Yang, W., Wan, Y., Chen, X., Chen, Z., et al. (2010). Seed Treatment with Uniconazole Powder Improves Soybean Seedling Growth under Shading by Corn in Relay Strip Intercropping System. Plant Production Science, 13(4), 367-374.

Yao, Y. (2011). Description of the Nfs. from http://aida.wss.yale.edu/ nq3/NANCYS Yale Website/resources/Data/Descriptionof-the-NFS.pdf (accessed 16.09.15)

Yi, F., Sun, D., \& Zhou, Y. (2015). Grain Subsidy, Liquidity Constraints and Food SecurityImpact of the Grain Subsidy Program on the Grain-Sown Areas in China. Food Policy, $50,114-124$.

Yin, R., \& Hyde, W. (2000). Trees as an Agriculture Sustaining Activity: The Case of Northern China. Agroforestry Systems, 50(2), 179-194.

Yu, Y., Stomph, T.-J., Makowski, D., \& van der Werf, W. (2015). Temporal Niche Differentiation Increases the Land Equivalent Ratio of Annual Intercrops: A MetaAnalysis. Field Crops Research, 184, 133-144.

Zhang, F., \& Li, L. (2003). Using Competitive and Facilitative Interactions in Intercropping Systems Enhances Crop Productivity and Nutrient-Use Efficiency. Plant and Soil, 248(1-2), 305-312. 
Zhang, L., Van der Werf, W., Zhang, S., Li, B., \& Spiertz, J. (2007). Growth, Yield and Quality of Wheat and Cotton in Relay Strip Intercropping Systems. Field Crops Research, 103(3), 178-188.

Zhu, Y., Chen, H., Fan, J., Wang, Y., Li, Y., Chen, J., et al. (2000). Genetic Diversity and Disease Control in Rice. Nature, 406(6797), 718-722.

Zhu, Z., Cai, M., Wang, S., \& Jiang, Y. (1991). Agroforestry Systems in China (Z. Zhaohua, C. Mantang, W. Shiji, \& J. Youxu Eds.). Beijing: Chinese Academy of Forestry and International Development Research Centre.

Zou, C., \& Li, Z. (2002). Intercropping and Relay Intercropping In Y. Shi (Ed.), Chinese Academic Canon in the 20th Century: Agriculture. Fuzhou. (in Chinese): Fujian Education Press.

Zou, X., \& Sanford Jr, R.L. (1990). Agroforestry Systems in China: A Survey and Classification. Agroforestry Systems, 11(1), 85-94. 


\section{Appendix}

Table A2.1 Glossary of cropping terms

\section{Definition}

\author{
Sole cropping \\ (single \\ cropping/stands) \\ Monoculture \\ (mono-cropping) \\ Multiple cropping
}

Agroforestry

Mixed cultivation (crop mixture)
The growing of one crop variety alone in pure stands at normal density (Andrews and Kassam, 1975).

The repetitive growing of the same crop on the same land in successive years (Andrews and Kassam, 1975).

Growing two or more crops on the same field in a year. Multiple cropping includes intercropping and sequential cropping (Andrews and Kassam, 1975).

Intercropping Cultivating two or more crop species (partly) simultaneously in the same field (Vandermeer, 1989; Lithourgidis et al., 2011), e.g. row intercropping, strip intercropping, relay intercropping and mixed intercropping.

Sequential Growing two or more crops successively on the same field in a cropping year, e.g. double cropping and triple cropping (Andrews and Kassam, 1975).

A land use system in which woody perennials are grown in association with agricultural crops or pastures, and in which there are both ecological and economic interactions between trees and the other components (Nair, 1985).

Cropping systems in which different crop (or tree) species or different varieties of the same crop species are grown simultaneously, or partly so, in the same field. Crop mixtures usually include agroforestry and intercropping (Li et al., 2013). 
Table A2.2 Available research on intercropping state and trend in China

\begin{tabular}{|c|c|c|}
\hline Publication & Estimates for China & Estimates for specific regions \\
\hline Tong, 1994 & $\begin{array}{l}\text { One third of the total arable land was under } \\
\text { multiple cropping in China }\end{array}$ & \\
\hline Li, 2001 & $\begin{array}{l}26.6 \% \text { of China's total arable land }{ }^{16} \text { in } \\
1995\end{array}$ & $\begin{array}{l}\text { Huang-Huai-Hai Plain: Area of } \\
\text { cotton/wheat relay } \\
\text { intercropping accounts for } \\
50.6 \% \text { of the total area. }\end{array}$ \\
\hline Zou and $\mathrm{Li}, 2002$ & $25.4 \%$ of China's arable land ${ }^{17}$ in $1990 \mathrm{~s}$ & \\
\hline Zhang and Li, 2003 & $\begin{array}{l}\text { One third of China's total arable land is } \\
\text { produced with multiple cropping }\end{array}$ & $\begin{array}{l}\text { Ningxia: land under } \\
\text { wheat/maize intercropping was } \\
75,100 \text { ha, accounting for } 5.6 \% \\
\text { of its provincial arable land } \\
\text { area in } 1995 \text {. } \\
\text { Gansu: land under wheat } / \text { maize } \\
\text { intercropping is } 200,000 \text { ha, } \\
\text { accounting for } 5.7 \% \text { of its } \\
\text { provincial arable land area. }\end{array}$ \\
\hline Li et al., 2007 & $17.8 \%$ of China's total sown area & \\
\hline Lichtfouse, 2009 & $20-25 \%$ of arable land under intercropping & \\
\hline Feike et al., 2012 & & $\begin{array}{l}\text { North China Plain: Around 5\% } \\
\text { of arable land under } \\
\text { intercropping in } 2012 \text {. }\end{array}$ \\
\hline
\end{tabular}

${ }^{16} \mathrm{Li}$ (2001) states that “...there are about $4.7 \times 10^{7}$ ha of farmland with multiple cropping, of which $3.4 \times 10^{7}$ ha are farmland with relay-intercropping and intercropping". We calculate the share of arable land under intercropping from this information by dividing the area of (relay-)intercropping by the arable land area of China (obtained from (NBS, 2002).

${ }^{17}$ Zou and $\mathrm{Li}$ (2002) state that "the area of intercropping reached 33 million ha...". We calculate the share of arable land under intercropping by dividing this figure by the arable land area of China (obtained from (NBS, 2003). 
Table A2.3 Agricultural land use classification

\begin{tabular}{|c|c|c|}
\hline $1^{\text {st }}$ class level & $2^{\text {nd }}$ class level & Definition \\
\hline \multirow[t]{4}{*}{ Arable land } & & $\begin{array}{l}\text { Land is plowed constantly for growing crops, including cultivated } \\
\text { land, newly cultivated land, farmland left without cultivation for less } \\
\text { than three years and fallow land in the current year, rotation land, } \\
\text { farmland with some fruit trees, mulberry trees and other trees and } \\
\text { cultivated seashore land, and lake shore land. The land of mulberry } \\
\text { fields, tea plantations, orchards, nurseries of young plants, forest land, } \\
\text { reed land, natural and man-made grassland and other land are not } \\
\text { included in cultivated land. Ditches, roads and ridges between } \\
\text { cultivated fields that are less than } 1 \text { meter in width in the southern } \\
\text { China or less than } 2 \text { meters in width in the northern China are included } \\
\text { in the cultivated land. }\end{array}$ \\
\hline & Paddy land & $\begin{array}{l}\text { Land used for planting paddy rice, lotus etc., including rotation land } \\
\text { for paddy rice and dry farming crops. }\end{array}$ \\
\hline & Irrigated land & $\begin{array}{l}\text { Land has enough water supply and irrigation facilities for planting dry } \\
\text { farming crops, including land used for cultivating greenhouse } \\
\text { vegetables. }\end{array}$ \\
\hline & Dry land & Land used for rain fed crops cultivation. \\
\hline \multirow[t]{4}{*}{ Plantation land } & & $\begin{array}{l}\text { Land where intensive operation of years on woody and herbal } \\
\text { perennial, for the harvest of fruits, leaves, roots, stems, juice, etc., the } \\
\text { groundcover above } 50 \% \text { or plant density per mu is } 70 \% \text { higher than } \\
\text { rational value, including the land for cultivating sapling. }\end{array}$ \\
\hline & Orchard land & Land used for cultivating fruits. \\
\hline & Tea land & Land used for cultivating tea. \\
\hline & $\begin{array}{l}\text { Other } \\
\text { plantation land }\end{array}$ & $\begin{array}{l}\text { Land used for cultivating mulberry, cocoa, oil palm, pepper, medicine } \\
\text { and other perennials. }\end{array}$ \\
\hline Forest land & & $\begin{array}{l}\text { Land where trees and bamboo grow with canopy density above } 0.2 \text {, } \\
\text { including land of natural woods and planted woods, but excluding } \\
\text { bush land and thin forest land. }\end{array}$ \\
\hline Grass land & & $\begin{array}{l}\text { Land with a vegetation-covering rate of over } 5 \% \text { that are used for } \\
\text { animal husbandry or harvesting of grass. }\end{array}$ \\
\hline Other & & Other agricultural purposes. \\
\hline
\end{tabular}


Table A2.4 Prevalence of intercropping in surveyed villages, 2009 and 2014

\begin{tabular}{|c|c|c|c|c|c|c|c|c|c|}
\hline \multirow[t]{2}{*}{ Province } & \multirow[t]{2}{*}{$\begin{array}{c}\text { No. of } \\
\text { surveyed } \\
\text { villages }\end{array}$} & \multicolumn{2}{|c|}{$\begin{array}{l}\text { No. of villages } \\
\text { with } \\
\text { intercropping }\end{array}$} & \multicolumn{2}{|c|}{$\begin{array}{l}\text { Total area of arable } \\
\text { land }\left(\mathrm{mu}^{18}\right)\end{array}$} & \multicolumn{2}{|c|}{$\begin{array}{c}\text { Total area under } \\
\text { intercropping } \\
(\mathrm{mu})\end{array}$} & \multicolumn{2}{|c|}{$\begin{array}{c}\text { Share of arable } \\
\text { land under } \\
\text { intercropping } \\
(\%)\end{array}$} \\
\hline & & 2009 & 2014 & 2009 & 2014 & 2009 & 2014 & 2009 & 2014 \\
\hline Hebei & 7 & 0 & 0 & 17,010 & 16,878 & 0 & 0 & 0.00 & 0.00 \\
\hline Liaoning & 11 & 0 & 0 & 47,558 & 47,065 & 0 & 0 & 0.00 & 0.00 \\
\hline Anhui & 11 & 1 & 1 & 41,664 & 40,218 & 138 & 110 & 0.33 & 0.27 \\
\hline Fujian & 8 & 2 & 2 & 19,408 & 19,503 & 663 & 930 & 3.42 & 4.69 \\
\hline Yunnan & 7 & 3 & 4 & 26,572 & 27,954 & 1,937 & 2,122 & 7.29 & 7.59 \\
\hline Shaanxi & 19 & 5 & 6 & 28,203 & 25,951 & 1,434 & 1,635 & 5.08 & 6.30 \\
\hline Total & 63 & 11 & 13 & 180,415 & 177,569 & 4,171 & 4,797 & 2.31 & 2.70 \\
\hline
\end{tabular}

Source: RFOPS village leader survey, 2014.

${ }^{18} 1 \mathrm{mu}=1 / 15$ hectare. 
Table A2.5 Prevalence of agroforestry on arable land in surveyed villages, 2009 and 2014

\begin{tabular}{|c|c|c|c|c|c|c|c|c|c|}
\hline \multirow[t]{2}{*}{ Province } & \multirow[t]{2}{*}{$\begin{array}{c}\text { No. of } \\
\text { surveyed } \\
\text { villages }\end{array}$} & \multicolumn{2}{|c|}{$\begin{array}{l}\text { No. of villages with } \\
\text { agroforestry }\end{array}$} & \multicolumn{2}{|c|}{$\begin{array}{l}\text { Total area of arable } \\
\text { land }(\mathrm{mu})\end{array}$} & \multicolumn{2}{|c|}{$\begin{array}{l}\text { Total area } \\
\text { under } \\
\text { agroforestry } \\
\text { (mu) }\end{array}$} & \multicolumn{2}{|c|}{$\begin{array}{l}\text { Share of arable } \\
\text { land under } \\
\text { agroforestry }(\%)\end{array}$} \\
\hline & & 2009 & 2014 & 2009 & 2014 & 2009 & 2014 & 2009 & 2014 \\
\hline Hebei & 7 & 0 & 0 & 17,010 & 16,878 & 0 & 0 & 0 & 0 \\
\hline Liaoning & 11 & 0 & 0 & 47,558 & 47,065 & 0 & 0 & 0 & 0 \\
\hline Anhui & 11 & 1 & 1 & 41,664 & 40,218 & 65 & 65 & 0.16 & 0.16 \\
\hline Fujian & 8 & 0 & 0 & 19,408 & 19,503 & 0 & 0 & 0 & 0 \\
\hline Yunnan & 7 & 0 & 0 & 26,572 & 27,954 & 0 & 0 & 0 & 0 \\
\hline Shaanxi & 19 & 7 & 8 & 28,203 & 25,951 & 1,822 & $\begin{array}{r}2,15 \\
3\end{array}$ & 6.46 & 8.30 \\
\hline Total & 63 & 8 & 9 & 180,41 & 177,569 & 1,887 & 2,21 & 1.05 & 1.25 \\
\hline
\end{tabular}

Source: RFOPS village leader survey, 2014. 
Table A2.6 Prevalence of agroforestry in plantation and forest land in surveyed villages, 2009 and 2014

\begin{tabular}{|c|c|c|c|c|c|c|c|c|c|}
\hline \multirow[t]{2}{*}{ Province } & \multirow[t]{2}{*}{$\begin{array}{l}\text { No. of } \\
\text { surveyed } \\
\text { villages }\end{array}$} & \multicolumn{2}{|c|}{$\begin{array}{c}\text { No. of villages } \\
\text { with } \\
\text { agroforestry }\end{array}$} & \multicolumn{2}{|c|}{$\begin{array}{l}\text { Total area of } \\
\text { plantation and forest } \\
\text { land }(\mathrm{mu})\end{array}$} & \multicolumn{2}{|c|}{$\begin{array}{l}\text { Total area under } \\
\text { agroforestry } \\
\text { (mu) }\end{array}$} & \multicolumn{2}{|c|}{$\begin{array}{c}\text { Share of } \\
\text { plantation and } \\
\text { forest land under } \\
\text { agroforestry }(\%)\end{array}$} \\
\hline & & 2009 & 2014 & 2009 & 2014 & 2009 & 2014 & 2009 & 2014 \\
\hline Hebei & 7 & 0 & 0 & 33,996 & 34,857 & 0 & 0 & 0 & 0 \\
\hline Liaoning & 11 & 1 & 1 & 187,630 & 188,216 & 1,200 & 1,200 & 0.64 & 0.64 \\
\hline Anhui & 11 & 1 & 1 & 25,990 & 27,684 & 176 & 150 & 0.68 & 0.54 \\
\hline Fujian & 8 & 2 & 2 & 123,592 & 122,939 & 2,130 & 3,650 & 1.72 & 2.97 \\
\hline Yunnan & 7 & 3 & 3 & 74,252 & 73,809 & 2,146 & 1,903 & 2.89 & 2.58 \\
\hline Shaanxi & 19 & 0 & 0 & 49,157 & 47,736 & 0 & 0 & 0 & 0 \\
\hline Total & 63 & 7 & 7 & 494,617 & 495,241 & 5,652 & 6,903 & 1.14 & 1.39 \\
\hline
\end{tabular}

Source: RFOPS village leader survey, 2014. 
Table A2.7 Prevalence of mixed cultivation systems in surveyed villages, 2009 and 2014

\begin{tabular}{|c|c|c|c|c|c|c|c|c|c|}
\hline \multirow[t]{2}{*}{ Province } & \multirow[t]{2}{*}{$\begin{array}{l}\text { No. of } \\
\text { surveyed } \\
\text { villages }\end{array}$} & \multicolumn{2}{|c|}{$\begin{array}{l}\text { No. of villages } \\
\text { with mixed } \\
\text { cultivation systems }\end{array}$} & \multicolumn{2}{|c|}{$\begin{array}{l}\text { Total area of farm } \\
\text { land }(\mathrm{mu})\end{array}$} & \multicolumn{2}{|c|}{$\begin{array}{l}\text { Land under } \\
\text { mixed cultivation } \\
\text { systems (mu) }\end{array}$} & \multicolumn{2}{|c|}{$\begin{array}{l}\text { Share of land } \\
\text { under mixed } \\
\text { cropping (\%) }\end{array}$} \\
\hline & & 2009 & 2014 & 2009 & 2014 & 2009 & 2014 & 2009 & 2014 \\
\hline Hebei & 7 & 0 & 0 & 51,006 & 51,735 & 0 & 0 & 0 & 0 \\
\hline Liaoning & 11 & 1 & 1 & 235,188 & 235,281 & 1,400 & 1,200 & 0.60 & 0.51 \\
\hline Anhui & 11 & 3 & 3 & 67,654 & 67,902 & 379 & 325 & 0.56 & 0.49 \\
\hline Fujian & 8 & 3 & 3 & 143,000 & 142,442 & 2,793 & 4,580 & 1.95 & 3.22 \\
\hline Yunnan & 7 & 4 & 6 & 100,824 & 101,763 & 4,111 & 4,025 & 4.08 & 3.96 \\
\hline Shaanxi & 19 & 12 & 14 & 77,360 & 73,687 & 3,256 & 3,788 & 4.21 & 5.14 \\
\hline Total & 63 & 23 & 27 & 675,032 & 672,810 & 11,911 & 13,918 & 1.76 & 2.07 \\
\hline
\end{tabular}

Source: RFOPS village leader survey, 2014. 
Table A2.8 Descriptive statistics of variables used in the regression analyses

\begin{tabular}{|c|c|c|c|c|c|c|c|c|c|}
\hline & \multicolumn{4}{|c|}{2009} & \multicolumn{4}{|c|}{2014} & \multirow{3}{*}{ Source } \\
\hline & \multicolumn{4}{|c|}{$\mathrm{N}=63$} & \multicolumn{4}{|c|}{$\mathrm{N}=63$} & \\
\hline & Mean & S.D. & Min & Max & Mean & S.D. & Min & Max & \\
\hline \multicolumn{10}{|l|}{$\begin{array}{l}\text { Dependent } \\
\text { Variables }\end{array}$} \\
\hline $\begin{array}{l}\text { Share of } \\
\text { arable land } \\
\text { under } \\
\text { intercropping }\end{array}$ & 0.049 & 0.171 & 0 & 0.993 & 0.051 & 0.174 & 0 & 0.993 & $\begin{array}{r}\text { Village } \\
\text { leader survey }\end{array}$ \\
\hline $\begin{array}{l}\text { Share of } \\
\text { farmland } \\
\text { under mixed } \\
\text { cultivation }\end{array}$ & 0.027 & 0.057 & 0 & 0.250 & 0.030 & 0.072 & 0 & 0.370 & $\begin{array}{r}\text { Village } \\
\text { leader survey }\end{array}$ \\
\hline \multicolumn{10}{|l|}{$\begin{array}{l}\text { Independent } \\
\text { variables }\end{array}$} \\
\hline $\begin{array}{l}\text { Number of } \\
\text { laborers } \\
\text { (head) }\end{array}$ & 2.71 & 0.462 & 1.60 & 3.60 & 2.63 & 0.486 & 1.33 & 3.73 & $\begin{array}{r}\text { Farm } \\
\text { household } \\
\text { survey }\end{array}$ \\
\hline $\begin{array}{l}\text { Agricultural } \\
\text { machinery } \\
\text { power }(\mathrm{KW})\end{array}$ & 2.02 & 4.38 & 0 & 22.5 & 2.78 & 6.76 & 0 & 46.1 & $\begin{array}{r}\text { Farm } \\
\text { household } \\
\text { survey }\end{array}$ \\
\hline $\begin{array}{l}\text { Arable land } \\
(\mathrm{mu})\end{array}$ & 5.72 & 5.50 & 0.504 & 39.6 & 5.49 & 5.58 & 0.133 & 40.4 & $\begin{array}{r}\text { Village } \\
\text { leader survey }\end{array}$ \\
\hline $\begin{array}{l}\text { Farmland } \\
(\mathrm{mu})\end{array}$ & 25.5 & 42.9 & 0.56 & 264.2 & 25.4 & 45.6 & 0.49 & 293.0 & $\begin{array}{r}\text { Village } \\
\text { leader survey }\end{array}$ \\
\hline
\end{tabular}

Source: RFOPS village leader and farm household survey, $2014 .{ }^{\text {a }}$ Farmland is the total area of arable, plantation, and forest land. 
Table A2.9 Maximum likelihood estimates of tobit model for share of arable land under intercropping 20092014

\begin{tabular}{|c|c|c|c|c|}
\hline $\begin{array}{l}\text { Independent } \\
\text { Variable }\end{array}$ & With arable land & $\begin{array}{r}\text { Without arable } \\
\text { land }\end{array}$ & With arable land & $\begin{array}{r}\text { Without arable } \\
\text { land } \\
\end{array}$ \\
\hline $\begin{array}{l}\text { Number of } \\
\text { laborers }\end{array}$ & $\begin{array}{r}0.853 * * \\
(2.54)\end{array}$ & $\begin{array}{r}0.939 * * * \\
(2.64)\end{array}$ & $\begin{array}{r}0.710 * * * \\
(2.70)\end{array}$ & $\begin{array}{r}0.738 * * * \\
(2.79)\end{array}$ \\
\hline $\begin{array}{l}\text { Agricultural } \\
\text { machinery power }\end{array}$ & $\begin{array}{r}-0.364^{*} \\
(-1.75)\end{array}$ & $\begin{array}{r}-0.347 * \\
(-1.73)\end{array}$ & $\begin{array}{l}-0.031 \\
(-1.08)\end{array}$ & $\begin{array}{l}-0.034 \\
(-1.19)\end{array}$ \\
\hline Arable land & $\begin{array}{l}-0.031 \\
(-1.01)\end{array}$ & - & $\begin{array}{l}-0.015 \\
(-0.57)\end{array}$ & - \\
\hline Constant & $\begin{array}{r}-2.451 * * \\
(-2.43)\end{array}$ & $\begin{array}{r}-2.860 * * * \\
(-2.72)\end{array}$ & $\begin{array}{r}-2.216 * * * \\
(-2.74)\end{array}$ & $\begin{array}{r}-2.368 * * * \\
(-2.97)\end{array}$ \\
\hline Loglikelihood & -17.66 & -18.38 & -21.21 & -21.40 \\
\hline $\begin{array}{l}\text { Likelihood Ratio } \\
\text { (LR) test }\end{array}$ & $18.33 * * *$ & $16.89 * * *$ & $13.99 * * *$ & $13.61 * * *$ \\
\hline Pseudo $\mathrm{R}^{2}$ & 0.342 & 0.315 & 0.248 & 0.241 \\
\hline Sigma & 0.436 & 0.450 & 0.439 & 0.446 \\
\hline $\begin{array}{l}\text { No. of } \\
\text { observations }\end{array}$ & 63 & 63 & 63 & 63 \\
\hline
\end{tabular}


Table A2.10 Maximum likelihood estimates of tobit model for share of farmland under mixed cultivation

20092014

\begin{tabular}{|c|c|c|c|c|}
\hline $\begin{array}{l}\text { Independent } \\
\text { variable }\end{array}$ & With farmland & Without farmland & With farmland & Without farmland \\
\hline $\begin{array}{l}\text { Number of } \\
\text { laborers }\end{array}$ & $\begin{array}{r}0.125^{* *} \\
(2.39)\end{array}$ & $\begin{array}{r}0.122 * * \\
(2.24)\end{array}$ & $\begin{array}{r}0.175^{* * *} \\
(2.81)\end{array}$ & $\begin{array}{r}0.177 * * * \\
(2.83)\end{array}$ \\
\hline $\begin{array}{l}\text { Agricultural } \\
\text { machinery power }\end{array}$ & $\begin{array}{r}-0.026^{* *} \\
(-2.05)\end{array}$ & $\begin{array}{r}-0.023^{*} \\
(-1.86)\end{array}$ & $\begin{array}{r}-0.018^{*} \\
(-1.94)\end{array}$ & $\begin{array}{r}-0.018^{*} \\
(-1.85)\end{array}$ \\
\hline Farmland & $\begin{array}{l}-0.001 \\
(-1.34)\end{array}$ & - & $\begin{array}{l}-0.001 \\
(-1.00)\end{array}$ & - \\
\hline Constant & $\begin{array}{r}-0.344 * * \\
(-2.32)\end{array}$ & $\begin{array}{r}-0.364 * * \\
(-2.33)\end{array}$ & $\begin{array}{r}-0.488 * * * \\
(-2.76)\end{array}$ & $\begin{array}{r}-0.517 * * * \\
(-2.89)\end{array}$ \\
\hline Loglikelihood & -3.046 & -4.331 & -4.789 & -5.509 \\
\hline $\begin{array}{l}\text { Likelihood Ratio } \\
\text { (LR) test }\end{array}$ & $12.97 * * *$ & $10.39 * * *$ & $15.19 * * *$ & $13.75^{* * *}$ \\
\hline Pseudo $\mathrm{R}^{2}$ & 0.680 & 0.546 & 0.613 & 0.555 \\
\hline Sigma & 0.116 & 0.121 & 0.141 & 0.144 \\
\hline $\begin{array}{l}\text { No. of } \\
\text { observations }\end{array}$ & 63 & 63 & 63 & 63 \\
\hline
\end{tabular}




\section{Chapter 3}

The contribution of intercropping to the technical efficiency of smallholder farming: a case study in Gaotai, China 


\title{
3. The contribution of intercropping to the technical efficiency of smallholder farming: a case study in Gaotai, China ${ }^{19}$
}

\begin{abstract}
Intercropping entails the production of two or more crop species at the same time in the same field. This traditional farming method has generally a high efficiency of land use, but it is still an open question whether it contributes to a higher effectiveness with which a given set of inputs is used to produce agricultural output. Technical efficiency analysis can be used to provide an answer to this question. Here, we examine whether intercropping under current conditions in northwest China makes a positive or negative contribution to the technical efficiency of farming. Data on inputs and outputs of farms for the 2013 agricultural season were collected by a farm survey in Gaotai County, Gansu Province. Using stochastic frontier analysis we found that the average technical efficiency of the surveyed farmers was 0.85 . Controlling for other factors that may play a role, we found that technical efficiency scores are positively affected by the share of land assigned to intercropping. This finding indicates that potential negative effects of intercropping on the productivity of labor, fertilizer, irrigation water or other resources are more than offset by its higher land productivity as compared to mono-cropping.
\end{abstract}

Key words: Technical efficiency, intercropping, stochastic production frontier, resource use efficiency

\footnotetext{
${ }^{19}$ This chapter is about to be submitted to a peer-reviewed journal, as Hong, Y., Heerink, N., Zhao, M., and van der Werf, W. 'The contribution of intercropping to the technical efficiency of smallholder farming: a case study in Gaotai, China'.
} 


\subsection{Introduction}

It is expected that the world demand for food will increase for at least another two decades due to the continuing population and consumption growth, which will intensify the competition for scarce resources like land and water (Godfray et al., 2010). In China, population growth and a national policy aiming at self-sufficiency in grain production put a high pressure on land and water resources (Skinner et al., 2001). Major increases in the efficiency of land and water use in agriculture are needed to meet the challenge of land and water scarcity while demand for these resources from non-agricultural sectors is rising (Yao and Liu, 1998; Qu et al., 2011).

Intercropping can achieve high yields and high resource use efficiency, while counteracting resource degradation (Lithourgidis et al., 2011; Yu et al., 2015). Intercropping is defined as the cultivation of two or more crop species simultaneously in the same field for the whole or a part of their growing period (Vandermeer, 1989). As an ancient and traditional cropping system, intercropping is still applied worldwide (Francis, 1986; Lithourgidis et al., 2011), and can be found in several regions in China (Knörzer et al., 2009; Feike et al., 2012; Hong et al., 2017). Estimates of its importance in modern Chinese agriculture differ widely. Tong (1994) estimated that one third of the arable land was used for intercropping. However, recent estimates indicate that intercropping may covers approximately $2-5$ percent of the total arable land area (Feike et al., 2012; Hong et al., 2017).

Intercropping is generally considered to have a high efficiency of resource use (Lithourgidis et al., 2011). In particular, high levels of land use efficiency have been found for various intercropping systems (Vandermeer, 1989; Zhang and Li, 2003; Yu et al., 2015). This high land use efficiency may, however, be obtained at the expense of the efficiency with which other inputs like nutrients and water are used (Huang et al., 2015). Technical efficiency 
analysis may be used to assess the overall resource efficiency of intercropping as compared to the use of sole crops.

Only little research has been done on the overall efficiency of intercropping as a farming practice. Alene et al. (2006) estimated the technical efficiency of intercropping systems of annual and perennial crop species in southern Ethiopia. They found high levels of technical efficiency in intercropping, particularly among farmers that combined crops which make productive use of surplus family labour in slack periods. Dlamini et al. (2012) found that integrating maize with other species was positively associated with the technical efficiency of farmers in southeast Tanzania. Tchale and Sauer (2007), on the other hand, found a significant negative impact of intercropping on the technical efficiency of maize-based smallholder farmers in Malawi. Both Dlamini et al. (2012) and Tchale and Sauer (2007) did not motivate why intercropping was included as an explanatory indicator variable in the technical efficiency equation, nor did they discuss the estimation result of this dummy variable.

Intercropping techniques have long been practiced in northwestern China, especially in irrigated areas where the thermal time is not sufficient to grow two sequential crops in one growing season, but the temperature sum is sufficient to grow two species with partially overlapping growing periods ( $\mathrm{Li}$ et al., 2001; Li et al., 2006; Wang et al., 2015). Relay intercropping, in which crop species partially overlap in growing period, has become popular in this region (Li et al., 1999). It usually takes the form of strip intercropping, in which two or more crops are grown in strips wide enough to permit separate crop production but close enough for crops to interact.

Wheat/maize relay intercropping was developed as a highly productive system in the 1960s in Wuwei Prefecture and several other parts of Gansu province, and proved to be an efficient 
way to deal with the growing land scarcity (Li et al., 2005). After water use regulations made wheat/maize intercropping no longer feasible in Wuwei Prefecture, many farmers replaced it by pea/maize intercropping (Mao et al., 2012).

Available studies on the efficiency of wheat/maize intercropping systems in northwestern China focus on the land use efficiency and efficiency of other single resources, such as nutrients, water and radiation (Zhang and Li, 2003; Fan et al., 2013; Wang et al., 2015). These studies are mostly based on field experiments. Little is known about the technical efficiency of these intercropping systems at the farm level.

The aim of this study is to examine the contribution of intercropping to the technical efficiency of smallholder farming under current conditions in northwest China. To achieve this objective, we applied stochastic frontier analysis (Kumbhakar and Lovell, 2003) to detailed survey data collected among 360 farmers in Gaotai County, Gansu Province in 2014. A one-step procedure was used to estimate technical efficiency scores from a translog production frontier. The resulting farm-specific technical efficiency scores were regressed on a series of factors that may potentially affect technical efficiency, including the proportion of land under intercropping. Although our analysis is limited to a relatively small region in northwest China, the insights gained from it are likely to be relevant for other regions inside and outside China where (relay) intercropping methods are practiced.

The remainder of the paper is organized as follows. Theoretical considerations regarding the impact of intercropping on technical efficiency are presented in the next section. The econometric methodology is explained in Section 3.3, while the data set and specification of the variables used in the regression model are described in Section 3.4. Section 3.5 presents the results. Section 3.6 summarizes the main findings, discusses their policy implications and presents recommendations for further research. 


\subsection{Technical efficiency and intercropping}

Productivity growth is not only affected by technological innovation (technological change) but also by the efficiency with which available technologies are used (technical efficiency). Efficiency is an important factor in productivity growth, especially in developing agricultural economies (Ali and Chaudhry, 1990). The role of efficient use of scarce resources in fostering agricultural production has long been recognized and has motivated considerable research into the extent and sources of efficiency differentials in peasant farming (Bravo-Ureta and Pinheiro, 1993; Alene et al., 2006). A large number of production frontier studies have proliferated since Farrell (1957) introduced a deterministic frontier approach to the measurement of production efficiency. Schmidt (1985), Battese (1992) and Greene (2008) provide comprehensive reviews of empirical applications of production frontier methods.

The standard approach in studies of technical efficiency in agriculture has been to use singleoutput frontier production functions; various outputs of cropping systems are aggregated, mostly based on their monetary values, to a single measure of crop output in this approach. Most available studies have estimated technical efficiency scores and focus on monocropping systems, i.e. systems with one crop per field at any time (Battese et al., 1996; Seyoum et al., 1998; Wadud and White, 2000). Other studies have examined factors that affect differences in technical efficiency of farms with mono-cropping systems (Coelli and Battese, 1996; Athipanyakul et al., 2014).

The technical efficiency of farms in China and its determinants has also become an important topic in research on Chinese agriculture since the 1990s (Huang and Kalirajan, 1997; Xu and Jeffrey, 1998; Yao and Liu, 1998; Tian and Wan, 2000; Chen et al., 2009). The focus of these studies is also on mono-cropping systems. As far as we know, the technical efficiency of intercropping systems in China has not been examined so far. 
There are several reasons why the technical efficiency of crops grown under intercropping may be different from that of crops grown in monoculture. Systems like relay intercropping may enable a longer total growth duration than a sole crop; associated resources, especially light, are captured over a longer period and tend to increase yields as compared to sole crops (Yu et al., 2016). A second reason is that fact that the temporal spread of activities like planting, weeding and harvesting in intercropping systems often allows farmers to plant, weed and harvest using only, or predominantly, family labor and thereby lower the costs of labor as compared to less diversified systems (Shaxson and Tauer, 1992). Family labor is commonly used in the management of intercrops, because weeding, harvesting and other activities in intercrops call for care and sense of discrimination (Jodha, 1980). A third motivation is that intercropping often reduces production risks (Raseduzzaman and Jensen, 2017). Different crop species respond differently to weather extremes and to pest and disease outbreaks. When the growth of one crop in a field is negatively affected, the available resources may be used more fully by the other crop(s). Mixing species within a field therefore gives a higher assurance that the available growth resources are used and transformed into yield (Matlon and Fafchamps, 1989). Moreover, pests and diseases generally spread more easily in monocropping systems than in intercropping systems (Zhu et al., 2000; Machado, 2009).

Some resources may be used less efficiently in intercropping systems. For instance, Huang et al. (2015) found that labor use in a novel wheat - maize/watermelon intercropping system in the North China Plain is higher than in the traditional wheat - maize double cropping system. The increase in labor is attributed to the fact that the cash crop (watermelon) that is introduced in the system requires much labor, while maize needs to be sown by hand in the intercropping system. Likewise, Mkamilo et al. (2004) found that the estimated labor use of maize/sesame intercropping was much higher (i.e. on average $42 \%$ ) than that of pure stands in the southeast Tanzania. Huang et al. (2015) further found that irrigation water use and nutrient surpluses 
(particularly of $\mathrm{N}$ and $\mathrm{K}$ ) per unit land are significantly larger in the intercropping system than in the double-cropping system, because extra water and fertilizer are given at the watermelon transplanting stage and the watermelon fruit production stage, which co-occurs with the initial maize growth stage.

In conclusion, intercropping may have positive as well as negative effects on the efficiency of use of individual resources and its overall effect on technical efficiency in smallholder farming remains unclear. The overall impact is likely to differ between regions with different agro-ecological and socio-economic conditions. For instance, technical efficiency of intercropping may be relatively high in regions with much surplus labor (Alene et al., 2006) and in regions where the growing season is too short for growing two successive crops in a year, like the region in northwest China where we did our field research.

\subsection{Model specification}

\subsubsection{Technical efficiency and frontier production function}

Technical Efficiency (TE) is conceptualized either (output-oriented) as the ability of a producer to maximize output with given quantities of inputs and a certain technology or (input-oriented) as the ability of a producer to minimize input uses for a given quantity of output. Likewise, technical inefficiency (TIE) reflects either the failure of attaining the highest possible level of output for given inputs and technology, or the failure to use the minimum quantity of inputs for obtaining a certain output level under a given technology.

The stochastic frontier production model that is generally used for estimating technical (in)efficiency incorporates a composed error structure made up of a two-sided symmetric term 
and a one-sided component. The two-sided error captures random effects that are outside the control of the producer, including weather conditions and measurement errors or other statistical noise typical of empirical data, while the one-sided component reflects technical inefficiency, i.e. the distance of farm output from the production frontier.

The general stochastic frontier production model (Battese, 1992) can be expressed as:

$$
y_{i}=f\left(x_{i} ; \beta\right) \exp \left(v_{i}-u_{i}\right), i=1,2, \ldots N
$$

Where $y_{i}$ denotes the output of a single farm $i, x_{i}$ represents a vector of inputs used on the $i$-th farm, $\beta$ is a vector of unknown parameters to be estimated, $v_{i}$ is the two-sided error and $u_{i}$ is the one-sided error. The two-sided error $v_{i}$ is assumed to be independently and identically distributed as $N\left(0, \sigma_{v}^{2}\right)$, while $u_{i}$ is assumed to have a half-normal distribution, i.e. a nonnegative truncation of the $N\left(0, \sigma^{2}\right)$ distribution.

The TE of production for the $i$-th farm, is defined as the ratio of observed production to the maximum feasible production (Battese et al., 1996):

$$
T E_{i}=\frac{f\left(x_{i} ; \beta\right) \exp \left(v_{i}-u_{i}\right)}{f\left(x_{i} ; \beta\right) \exp \left(v_{i}\right)}=\exp \left(-u_{i}\right)
$$

Battese and Coelli (1988) suggest to predict TE by using its conditional expectation, given the composed random error, $v_{i}-u_{i}$, evaluated at the maximum-likelihood estimates of the parameters of the model.

The model used for explaining TIE, as proposed by Battese and Coelli (1996), is:

$$
T I E_{i}=z_{i} \delta+w_{i}
$$

$z$ is a $(1 \times M)$ vector of explanatory variables affecting TIE; $\delta$ is an $(M \times 1)$ vector of unknown parameters to be estimated; and $w_{i}$ are unobservable random errors which are assumed to be independently and identically distributed as $N\left(0, \sigma^{2}\right)$. 


\subsubsection{Empirical model}

We follow earlier studies, e.g. Battese and Broca (1997) and Guilkey et al. (1983), in using a translog specification for the production frontier. A translog function is flexible and can be interpreted as a second-order approximation to any true functional form (Abdulai and Tietje, 2007; Chen et al., 2009; Tan et al., 2010). Another popular specification for (farm) production functions or production frontiers is the Cobb-Douglas function, which is nested within the translog function. We will formally test which functional form is appropriate.

The translog function that we use in our empirical analysis is specified as:

$\ln Q_{i}=\beta_{0}+\beta_{0}^{*} D_{i}+\sum_{j=1}^{6} \beta_{j} \ln X_{i j}+\sum_{j=1}^{6} \sum_{k=1}^{6} \beta_{j k} \ln X_{i j} \ln X_{i k}+\beta_{0}^{* *}$ Fertile $_{i}+v_{i}-u_{i}$

$Q_{i}$ is the total value of all production output on farm $i, X_{j}$ represents the vector of inputs (seed, fertilizer, irrigation water, labor, land, and other inputs) used for growing crops, $D_{i}$ is a dummy variable that equals one when other inputs are used and zero otherwise, Fertile $_{i}$ is the ratio of fertile land to total land on the $i$ th farm; $\beta$ 's are unknown parameters to be estimated, $v_{i}$ are stochastic random errors, and $u_{i}$ are non-negative random errors accounting for technical inefficiency in production. The variable 'other inputs' comprises the (aggregated value of) use of pesticides, rented machinery and film mulch. It has a value of zero for some observations. To deal with this problem, we change these zero values into ones, and add the dummy variable $D_{i}$ to the model (Battese, 1997; Battese and Broca, 1997).

Estimates of TIE obtained by (4) will be used as the dependent variable in the TIE model that we specify as:

$$
T I E_{i}=\delta_{0}+\delta_{1} P_{i}+\delta_{2} A_{i}+\delta_{3} A^{2}{ }_{i}+\delta_{4} E_{1_{i}}+\delta_{5} E_{2 i}+\delta_{6} L_{i}+\delta_{7} L^{2}{ }_{i}+\delta_{8} P L_{i}+\delta_{9} T+\omega_{i}
$$


$P_{i}$ is the proportion of land under intercropping; $A_{i}$ is the age of the household head; $E_{1}$ is a dummy variable that equals one if the maximum education attainment of householder is primary school, zero otherwise; $E_{2}$ is a dummy variable that equals one if the maximum education attainment of householder is middle school or higher, zero otherwise; $L_{i}$ is the size of the cultivated (i.e. contracted plus net rented) land used by the household (in mu); $P L_{i}$ is the number of plots cultivated by the household; and $T$ is a dummy variable that equals one if the interviewed household lives in one of the two townships where we held survey, zero otherwise. The $\delta$ s in Eq. 5 are unknown parameters to be estimated.

Technical efficiency depends on farm management practices, like the timing of seeding, irrigating and harvesting, and the ways in which inputs are applied (Førsund et al., 1980). Farm management decisions in turn are related to a host of variables, like knowledge, experience and education (Gorton and Davidova, 2004; Bravo-Ureta et al., 2007).

The main explanatory variable of our interest is the proportion of the land area under intercropping. As explained in Section 3.2, there is uncertainty whether intercropping has a negative or positive effect on technical (in)efficiency because both arguments for a positive effect as for a negative can be brought forward.

The age of the farmers could either have a positive or a negative effect on TIE. The greater farming experience of older farmers could positively affect their technical efficiency. However, older farmers could also be less willing to adopt new practices and thereby have lower technical efficiency (Coelli and Battese, 1996; Feng, 2008). Labour productivity is likely to increase and then decrease with age (Liu and Zhuang, 2000). Because the optimal balance of skill and productivity may be achieved at an intermediate age, we include also the square of the age of the farmer to test for such nonlinearities. Education is expected to reduce 
TIE as better educated persons are expected to have a higher ability to understand and apply production technology (Coelli and Battese, 1996).

Plant growth, water and nutrient requirements, diseases and pests, crop damage caused by animals or thieves are easier to monitor on small farms as compared to large farms. On the other hand, small farmers are more likely to be engaged in off-farm employment which may negatively affect the time spent on monitoring and the appropriate timing of seeding, weeding, harvesting and other activities. Hence, the impact of farm size on TIE is indeterminate. To examine possible nonlinearities in the impact of land size on TIE, we included also the square of land size as an explanatory variable.

An increase in the number of plots (for a given farm size) could reduce TIE, because variations in agro-climatic conditions at micro-level imply that peaks in the demand for (family) labour and other inputs tend to level off and because diseases and pest are less likely to spread on fragmented farms as compared to farms of the same size with fewer plots. However, efficiency of water management may decrease with the number of plots, because different crops or crop varieties grown on different plots need water at different times and the timing usually needs to be tuned with farmers cultivating neighbouring plots. Moreover, the amount of (unproductive) time spent travelling between the family house and plots will usually be higher when the number of plots is larger, while monitoring of e.g. crop growth takes more effort when the number of plots is larger. Hence, the impact of the number of plots on TIE is indeterminate (Tan et al., 2010).

Finally, a dummy variable for one of the two townships where we held the survey is included in the model to capture the variation in other factors (e.g. information and credit accessibility) that may systematically differ between townships. 


\subsubsection{Estimation method}

The parameters of the stochastic frontier function model were estimated with maximum likelihood using the computer program FRONTIER 4.1 (Coelli, 1996). We adopted the onestep estimation procedure, in which the relationship between technical (in)efficiency and its explanatory variables (Eq. 5) is imposed directly in estimating the frontier production function (Eq. 4) and the farm's (in)efficiency level (Kumbhakar et al., 1991; Battese et al., 1996; Wang and Schmidt, 2002).

The elasticity of each input is calculated from the estimated coefficients and the mean values of the logarithms of dependent and explanatory variables as:

$$
\eta_{i}=\beta_{i}+2 \beta_{i i} \ln x_{i}+\sum_{j \neq i} \beta_{j i} \ln x_{j}
$$

We combined the estimated coefficients and household-specific information to estimate inputoutput elasticities for each household in our sample. The resulting household-specific estimates were used to obtain standard errors and t-ratios of the input-output elasticities.

\subsection{Data set}

\subsubsection{Data collection and sampling}

During the period August 2014 to November 2014, survey teams from Northwest Agricultural and Forestry University, Yangling and the University of Chinese Academy of Sciences, Beijing conducted a survey in the Heihe River basin in Gansu province and Inner-Mongolia. The Heihe River is an inland river that originates in the Qilian Mountains in Qinghai Province, flows northwards through Gansu Province and ends in Juyanhai Lake in the Inner Mongolia Autonomous Region. The main goal of the survey was to assemble information on farm livelihoods and water use in different parts of the river basin. Data were collected on use 
of inputs in agricultural production, agricultural output, consumption and expenditure, and farmers' attitude towards the current water policy.

The data used in this study was obtained from a sub-sample conducted in Zhangye City, Gansu Province. Zhangye City is an oasis located midstream of the Heihe River. The annual precipitation is $89-283 \mathrm{~mm}$, with 70 to $90 \%$ concentrated in the period July to September, while evaporation is about 1,700 mm per year (Zhang, 2007), resulting in a desert climate type. Due to the availability of irrigation water from the Heihe River, the flat and fertile land and abundant sunshine, the area has become a major grain (seed) and vegetable (seed) base in Gansu Province (Luo et al., 2005; Yang and Liu, 2010; Zhang et al., 2013).

The Gaotai County region, located between $98^{\circ} 57^{\prime}-100^{\circ} 06^{\prime} \mathrm{E}, 39^{\circ} 03^{\prime}-39^{\circ} 59^{\prime} \mathrm{N}$, is one of the six administrative counties in Zhangye City (see Figure 3.1). Wheat and maize are the main staple food crops, while beans, cotton, rapeseed and seed crops are grown as cash crops. Wheat intercropped with maize and seed crops (particularly cumin and watermelon) intercropped with maize are important intercropping systems in the region. 


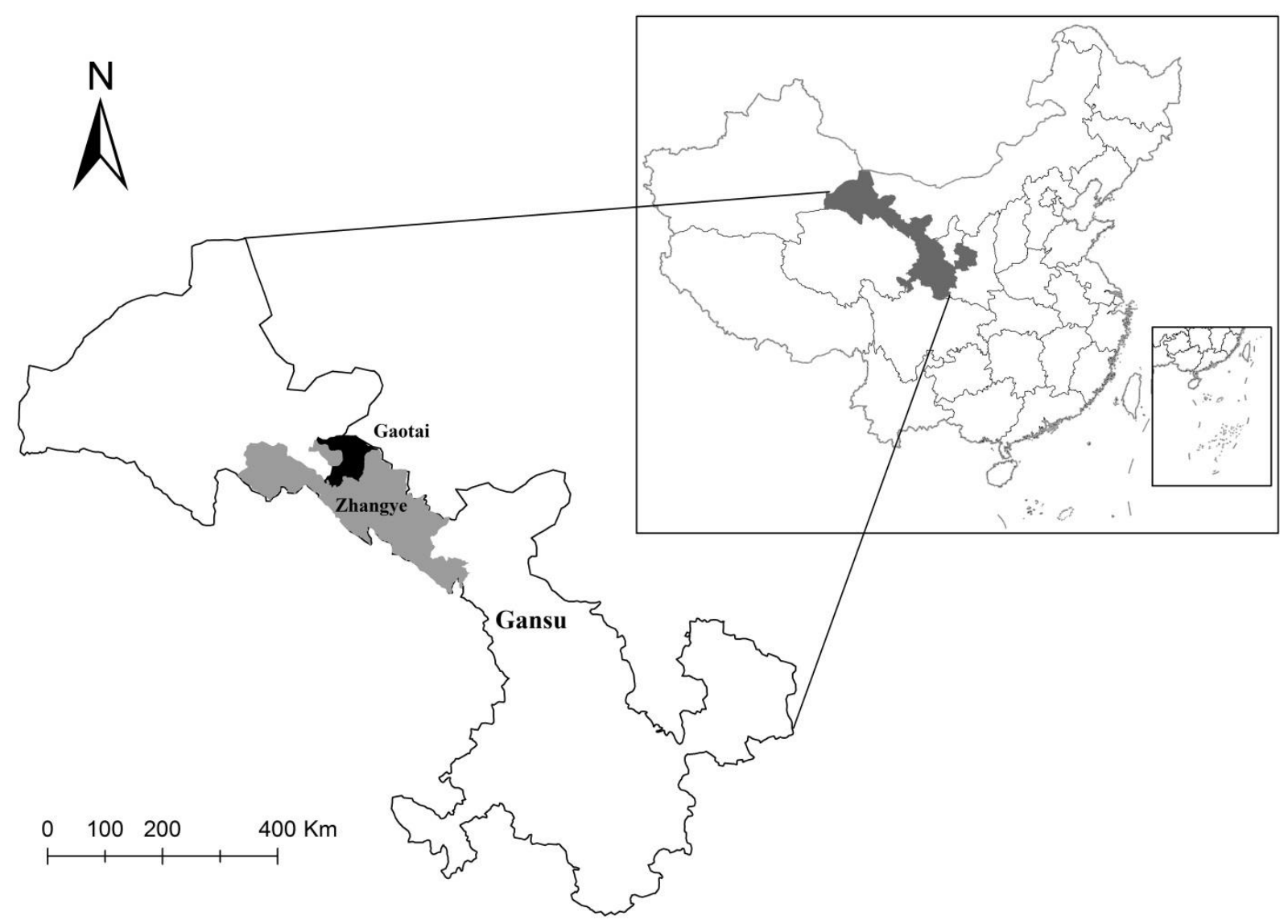

Figure 3.1 Map of study area

Two townships in Gaotai County - Luocheng and Heiquan - were selected for data collection for this specific study. In both townships intercropping systems have historically been popular and are still important. Three villages in Luocheng township and two villages in Heiquan township were randomly selected. Within each village, interviewees were randomly selected among the households that were present in the village at the time of the farm survey. In total, 360 farm householders ${ }^{20}$ were interviewed about their inputs use and outputs during the 2013 agricultural season. Since 129 farmers did not provide complete information on major

\footnotetext{
${ }^{20}$ When householders were absent, we interviewed one of the other members in the family who could provide relevant information.
} 
variables in our analysis, like labor and irrigation water input, they were excluded from the sample. The final sample therefore included 231 households.

\subsubsection{Input and output variables}

Output was measured as the total value of crop output produced at the farm. Values were derived by using (contract or market) prices $^{21}$ received for each crop (in yuan ${ }^{22}$ ). Inputs used in the study include land area under crops $\left(\right.$ in $\mathrm{mu}^{23}$ ), labor employed in cropping (measured in man-days per year), seed expenditures (in yuan), hired machinery (in yuan), film mulch (in yuan), pesticide and fertilizer (in yuan), irrigation water (number of irrigation rounds multiplied by farm area), and fertile land ratio (derived as the share of good quality land in the farm, as assessed by the respondent).

Descriptive statistics of the inputs and output are presented in Table 3.1. The average farm size in the sample equals $11.0 \mathrm{mu}$. It ranges from 1.3 to $38 \mathrm{mu}$. The proportion of the land under intercropping equaled 0.60 in the year 2013. This result confirms that intercropping is common in the study region. The mean number of plots was near 9 , with an observed maximum of 25, indicating a large degree of fragmentation. The average number of labor days worked on a farm in 2013 ranges from 6.4 days to 432 days, with an average of 108 days. Fertilizer is the main cost item, with a mean cost of slightly more than 3,500 Yuan. There is large spread in the data on this input, with costs ranging from only 394 Yuan up until 37,050 Yuan. Seed is another important input cost, with a mean value of more than 1,000 Yuan. High quality seed is commonly used in the study region. Aggregate costs of mulch,

\footnotetext{
${ }^{21}$ Output that was not sold was valued at contract or market prices. In case of missing observations for prices of outputs, we use the average price for sampled households within the same village or, if the number of observations within the same village is less than five, within the same township.

221 yuan equalled ca. 0.16 dollar in 2013 .

231 mu equals $1 / 15$ hectare.
} 
pesticides and hired machinery are also slightly larger than 1,000 Yuan. Some farmers in the sample did not spend any money in 2013 on these other inputs. 
Table 3.1 Descriptive statistics of variables used

Mean S.D. Min. Max. Units Definition

No. of observations $=231$

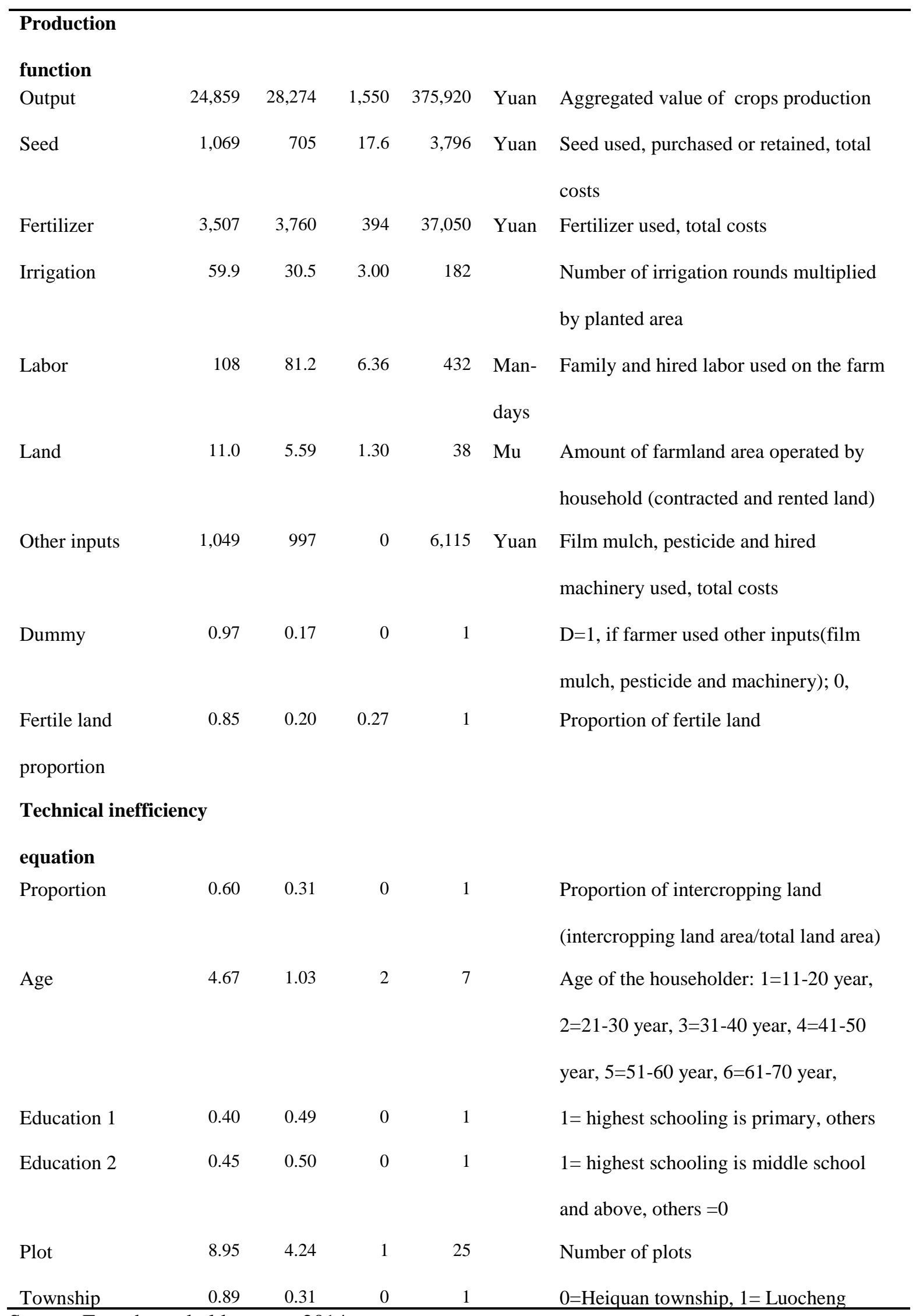

Source: Farm household survey, 2014. 


\subsection{Empirical results and interpretation}

\subsubsection{Production frontier}

As a first step, we tested whether a Cobb-Douglas or a translog functional form is more appropriate for the production frontier. We used the likelihood ratio test to test the hypothesis that the coefficients of the interactions between the inputs are jointly equal to zero $\left(\mathrm{H}_{0}: \beta_{j k}=\right.$ 0 , in the Eq. 4). The test result ${ }^{24}$ indicated that the null hypothesis should be rejected at $10 \%$ level, indicating that the translog has a better support from the data.

The results of the translog production frontier estimation are presented in Table 2 . The value of the generalized likelihood ratio test $(38.14)$ exceeds the critical value $\left(\chi^{2}(11)=24.73\right)$ at $1 \%$ level, hence the null hypothesis that the sampled farms are fully technically efficient should be rejected. This result provides statistical support for the presence of a one-side error component characterizing TIE, and suggests that a conventional production function (i.e. one lacking technical efficiency) is not an adequate representation of the data. The estimated value of 0.38 for the variance parameter, $\gamma$, indicates that $38 \%$ of the variation in residual output can be explained by TIE and $62 \%$ by random disturbances caused e.g. by weather conditions or measurements errors.

\footnotetext{
${ }^{24}$ The likelihood ratio test statistic $\left(\chi^{2}\right)$ is 31.24 , while the critical value of $\chi^{2}$ with degrees of freedom of 21 , and P-value of 0.1 , is 29.62. The null hypothesis is therefore is rejected.
} 
Table 3.2 Estimation results for translog production frontier, maximum likelihood

\begin{tabular}{|c|c|c|c|}
\hline Variables & Coefficient & s.e. & t-ratio \\
\hline Constant & $7.907 * * *$ & 2.575 & 3.071 \\
\hline $\ln ($ seed $)$ & 0.003 & 0.660 & 0.004 \\
\hline $\ln$ (fertilizer) & -0.025 & 0.525 & -0.047 \\
\hline $\ln$ (irrigation) & 0.581 & 0.968 & 0.600 \\
\hline $\ln ($ labor $)$ & -0.497 & 0.566 & -0.879 \\
\hline $\ln$ (land) & -0.421 & 1.272 & -0.331 \\
\hline $\ln$ (other inputs) & 0.482 & 0.376 & 1.283 \\
\hline $\ln (\text { seed })^{2}$ & $-0.047^{*}$ & 0.027 & -1.753 \\
\hline $\ln (\text { fertilizer })^{2}$ & -0.050 & 0.037 & -1.324 \\
\hline $\ln (\text { irrigation })^{2}$ & $-0.209 *$ & 0.112 & -1.865 \\
\hline $\ln (\text { labor })^{2}$ & $0.073 * *$ & 0.034 & 2.147 \\
\hline $\ln (\text { land })^{2}$ & 0.000 & 0.247 & 0.001 \\
\hline $\ln (\text { other inputs })^{2}$ & -0.002 & 0.022 & -0.108 \\
\hline $\ln ($ seed $) * \ln ($ fertilizer $)$ & 0.089 & 0.094 & 0.938 \\
\hline $\ln ($ seed $) * \ln ($ irrigation $)$ & -0.012 & 0.181 & -0.064 \\
\hline $\ln ($ seed $) * \ln ($ labor $)$ & -0.027 & 0.080 & -0.336 \\
\hline $\operatorname{Ln}($ seed $) * \ln ($ land $)$ & 0.005 & 0.222 & 0.024 \\
\hline $\ln ($ seed $) * \ln$ (other inputs) & 0.004 & 0.036 & 0.120 \\
\hline $\ln ($ fertilizer)* $\ln$ (irrigation) & 0.136 & 0.129 & 1.050 \\
\hline $\ln ($ fertilizer)* $\ln$ (labor) & 0.027 & 0.052 & 0.515 \\
\hline $\ln ($ fertilizer $) * \ln ($ land $)$ & -0.184 & 0.154 & -1.199 \\
\hline $\ln ($ fertilizer) $* \ln$ (other inputs) & -0.006 & 0.040 & -0.155 \\
\hline $\ln$ (irrigation)* $\ln ($ labor) & -0.049 & 0.105 & -0.468 \\
\hline $\ln$ (irrigation)* $\ln ($ land) & 0.435 & 0.265 & 1.640 \\
\hline $\ln$ (irrigation)* $\ln$ (other inputs) & -0.131 & 0.089 & -1.467 \\
\hline $\ln ($ labor $) * \ln ($ land $)$ & 0.085 & 0.143 & 0.594 \\
\hline $\ln ($ labor)* $\ln$ (other inputs) & -0.009 & 0.028 & -0.317 \\
\hline $\ln ($ land $) * \ln ($ other inputs) & 0.100 & 0.103 & 0.976 \\
\hline Dummy & -0.375 & 0.963 & -0.390 \\
\hline Fertile land ratio & $0.362 * * *$ & 0.125 & 2.887 \\
\hline$\sigma^{2}=\sigma_{v}^{2}+\sigma_{u}^{2}$ & $0.145^{* * *}$ & 0.019 & 7.780 \\
\hline$\gamma=\sigma_{u}^{2} / \sigma_{v}^{2}+\sigma_{u}^{2}$ & $0.377 * * *$ & 0.110 & 3.439 \\
\hline No. of observation & \multirow{2}{*}{\multicolumn{3}{|c|}{$\begin{array}{c}231 \\
64.08\end{array}$}} \\
\hline Log likelihood function & & & \\
\hline
\end{tabular}

*, ** and $* * *$ indicate statistical significance at $10 \%, 5 \%$ and $1 \%$ levels, respectively. 


\subsubsection{Input-output elasticities}

The estimated input-output elasticities of the variables in the production frontier are reported in Table 3.3. Land is found to have the largest impact on crop production with an elasticity of 0.896. This result indicates that increases in cultivated land areas have a major impact on farm output. Similar large elasticities for land, ranging from 0.625 to 0.945 , have been found for Chinese agriculture by Yao and Liu (1998), Feng et al. (2008), Tan et al. (2010) and Ma et al. (2017). Other inputs (rented machinery, pesticide and film mulch) are also important with an output elasticity of 0.106 . Estimated elasticities for seed, fertilizer, irrigation and labor do not differ significantly from zero.

The sum of estimated input-output elasticities, i.e. the scale elasticity, equals 0.898 . It is slightly smaller than the value of 0.942 found in Sichuan province and the value of 1.054 found in Jiangsu province by Liu and Zhuang (2000), and the value of 1.00 found by Chen et al. (2009) in Shaanxi and Hebei in northern China. Tan et al. (2010), on the other hand, estimated scale elasticities for early, late and single rice in northeast Jiangxi Province that ranged from $0.782-0.927$

Table 3.3 Estimated input-output elasticities

\begin{tabular}{|c|c|c|}
\hline Input & Elasticity & t-ratio \\
\hline Seed & 0.054 & -0.690 \\
\hline Fertilizer & -0.014 & -0.156 \\
\hline Irrigation & -0.146 & -0.640 \\
\hline Labor & 0.110 & 0.822 \\
\hline Land & $0.896 * * *$ & 2.884 \\
\hline Other inputs & $0.106^{* *}$ & 1.946 \\
\hline Scale elasticity & 0.898 & - \\
\hline
\end{tabular}




\subsubsection{Technical efficiency estimates}

TE estimates of individual farms are presented in Figure 3.2. They range from 0.18 to 0.97 , with a mean value of 0.85 and a standard deviation of 0.17 . Eighty percent of the sampled farms has estimated efficiency scores of 0.8 or more. The average TE for our sample is comparable to the value of 0.82 found by Ma et al. (2017) in Minle county, Gansu province in 2010, the value of 0.80 found by Chen et al. (2009) in Shaanxi and Hebei (northern China) over the period 1995-1999, and the values of $0.80-0.91$ estimated by Tan et al. (2010) for rice crops in northwest Jiangxi (central-south China) in 2000.

The estimated TE score means that the value of crop production falls on average $15 \%$ short of the level that can be achieved by the most efficient farmers. This suggests that in the short run (no technological change), there is still considerable room to increase crop yields at the current levels of input use even for the majority of farmers who have above average TE levels.

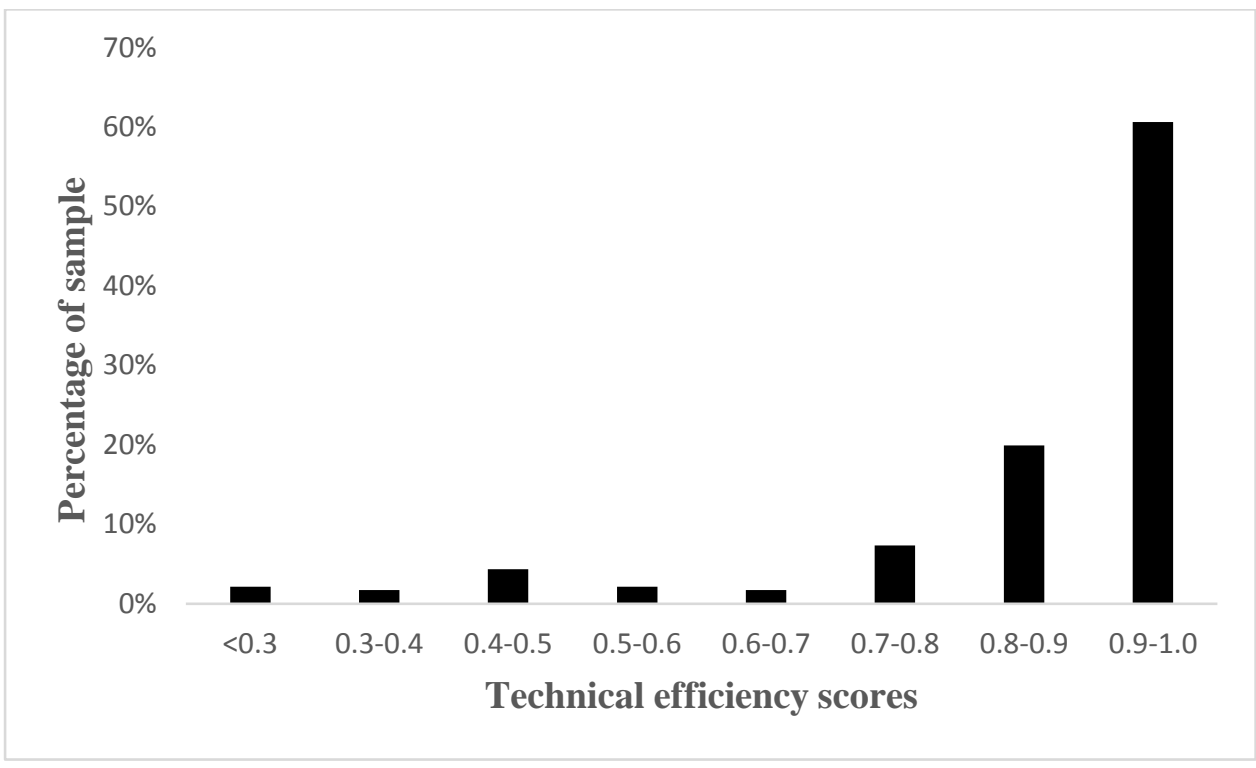

Figure 3.2 Frequency distribution of estimated technical efficiencies 


\subsubsection{Factors influencing technical efficiency}

The dependent variable in the inefficiency function is the estimated TIE. Hence, a positive sign of an estimated coefficient implies that the associated variable has a negative effect on technical efficiency (TE), and a negative sign means that the variable has a positive effect on TE. Estimation results of the TIE equation are shown in Table 3.4. We will focus on their interpretations in terms of TE.

The estimated coefficient of the main variable of our interest, the share of land under intercropping, is negative and highly significant. The corresponding elasticity equals -0.744 . Taking into account the relatively high land use efficiency of intercropping systems observed in many studies, this finding indicates that potential negative effects of intercropping on the productivity of labor, fertilizer, irrigation water or other resources are more than offset by the high land productivity as compared to mono-cropping. The traditional wheat-maize intercropping system, which has been practiced in the Hexi corridor for a long period (nearly 40 years), is still practiced on $23 \%$ of the land in the surveyed villages. It may therefore be assumed that farmers have gained much experience with this particular system, and have used this experience to optimise the overall efficiency of this system as well as other intercropping systems in the course of time.

As regards the control variables, we found that the coefficient for the age of household head is negative and significant, while the square of age is positive and significant. These findings indicate that experience plays an important role in crop production, but that its marginal impact on TE declines with rising age. This result is consistent with the findings of Liu and Zhuang (2000) for Sichuan province in southwest China.

The estimated coefficient of land area is negative and statistically significant, while the coefficient of squared area is also significant but has a positive sign. This finding indicates 
that there exists a non-linear relationship between farm size and TE, with larger land holdings having larger levels of efficiency than smaller land holdings. Maximum TE is achieved at a land size of ca. $22 \mathrm{mu}$, i.e. twice the average size of farms in the sample.

The estimated coefficients for the two education variables do not significantly differ from zero (at the 5 percent level). Although better educated farmers are expected to perform agricultural activities in a more efficient way, they also have a higher probability of being engaged in rural-urban migration (Shi et al., 2007; Wei and Wang, 2011) and therefore may spend less time on monitoring and may have a suboptimal timing in performing on-farm activities. We also found that the number of plots has a significant, positive impact on TE. In other words, the potential positive effects of having more plots on efficiency outweighed the potential negative effects for the farmers in the sample. This finding is consistent with the positive effect of land fragmentation on TE found in studies for Jiangxi province (Tan et al., 2010) and for Gansu province (Ma et al., 2017).

Finally, the significant positive coefficient for the township dummy indicates that farms in Luocheng township have a lower TE than those in Heiquan township, when other factors affecting TE remain constant. Differences in agro-climatic factors and market conditions may explain this finding. 
Table 3.4 Estimation results for technical inefficiency model, maximum likelihood ${ }^{1}$

\begin{tabular}{lrrr}
\hline Variable & Coefficient & \multicolumn{1}{c}{ Elasticity ${ }^{2}$} & t-ratio \\
\hline Constant & $2.978^{* * * *}$ & - & 3.216 \\
Proportion & $-1.054^{* * *}$ & -0.744 & -5.143 \\
Age & $-0.765^{* *}$ & -4.203 & -2.208 \\
Age & & 2.309 & 2.581 \\
Education1 & $0.090^{* *}$ & 0.036 & 0.541 \\
Education2 & 0.077 & -0.106 & -1.171 \\
Land & -0.200 & -1.941 & -3.797 \\
Land & 2 \\
Plot & $-0.150^{* * *}$ & 0.427 & 3.861 \\
Township & $0.003 * * *$ & -0.526 & -1.858 \\
No. of observations & $-0.050^{*}$ & 0.440 & 1.881 \\
Log likelihood function & $0.420^{*}$ & & \\
\hline
\end{tabular}

$*, * *$ and $* * *$ indicate statistical significance at $10 \%, 5 \%$ and $1 \%$ levels respectively.

${ }^{1}$ The dependent variable is technical inefficiency, which is jointly estimated with the frontier function in a one-step procedure using FRONTIER 4.1.

${ }^{2}$ Elasticities are evaluated at mean values. 


\subsection{Conclusion}

This study has examined the technical efficiency (TE) of farms in northwest China and the contribution of intercropping and other factors to the level of TE. To this end, a translog stochastic frontier function and an efficiency equation were estimated from farm input and output data collected among 231 farm household in Gaotai County in the Heihe River Basin in northwestern China. The main finding is that intercropping has a statistically significant positive effect on TE. The estimated elasticity of the proportion of land under intercropping equals 0.79 , indicating that technical efficiency goes up by $0.79 \%$ if the proportion of land under intercropping increases by $1 \%$. The large and significant value of this estimate gives strong support to the view that intercropping is relatively efficient land use system in the case study area.

Our results show that under the current technologies there is still considerable scope for increasing TE in the region that we examined. Increasing the proportion of land under intercropping may play an important role in this respect, given that $60 \%$ of the land in this region was under intercropping in 2013 and that the elasticity of TE to the proportion of land under intercropping is close to 0.8 . The resulting expected increase in TE will contribute to increasing farm output without changing the total land area under cultivation. Previous studies have shown that the productivity of labor, irrigation water and fertilizer may be lower in intercropping systems as compared to mono-cropping. The results of our study suggest that the superior land productivity more than compensates for this in the case of the relay intercropping systems practiced by the farmers in our sample.

Farm size was found to play a key role among the control variables affecting TE. The nonlinear relationship between the area of the cultivated land and TE that we estimated implies that ongoing policies aimed at scale enlargement in agriculture, through the promotion of so- 
called family farms and renting out of land to cooperatives and private companies, may make a positive contribution to the overall efficiency of farming in the region that we examined. TE was estimated to be highest for farms that are twice as large as the average size observed for the farms in our sample.

The TE analysis that we employed in this study takes the available technology at the time of the survey as given. Evidently there is also much scope for productivity gains through the development and introduction of new technologies, in intercropping systems as well as single crop systems. In the case of intercropping systems, this may imply promotion of new varieties to replace the conventional ones in its component crops and the development of specialized machinery for intercropping systems to reduce its large labor demand (see also Huang et al., (2015)). But these are beyond the scope of the current study.

\section{Acknowledgements}

We gratefully acknowledge the time and efforts spent by the survey team of Northwest Agricultural and Forestry University and the University of Chinese Academy of Sciences in collecting the data that we used for this study. The financial support from the China Scholarship Council (CSC, grant number: 201206300117) and the Key Sino-Dutch Joint Research Project of NSFC (Grant number: 31210103906) are gratefully acknowledged. We thank prof. Zhang Fusuo for his encouragement and helpful discussion. 


\section{References}

Abdulai, A., \& Tietje, H. (2007). Estimating Technical Efficiency under Unobserved Heterogeneity with Stochastic Frontier Models: Application to Northern German Dairy Farms. European Review of Agricultural Economics, 34(3), 393-416.

Alene, A.D., Manyong, V.M., \& Gockowski, J. (2006). The Production Efficiency of Intercropping Annual and Perennial Crops in Southern Ethiopia: A Comparison of Distance Functions and Production Frontiers. Agricultural Systems, 91(1-2), 51-70. doi: 10.1016/j.agsy.2006.01.007

Ali, M., \& Chaudhry, M.A. (1990). Inter - Regional Farm Efficiency in Pakistan's Punjab: A Frontier Production Function Study. Journal of Agricultural Economics, 41(1), 62-74. Athipanyakul, T., Jitsaeng, P., Pongkapan, N., \& Pakdee, P. (2014). Key Factors for Improving Technical Efficiency of Upland Rice Production. American Journal of Applied Sciences, 11(2), 266.

Battese, G.E. (1992). Frontier Production Functions and Technical Efficiency: A Survey of Empirical Applications in Agricultural Economics. Agricultural Economics, 7(3), 185208.

Battese, G.E. (1997). A Note on the Estimation of Cobb - Douglas Production Functions When Some Explanatory Variables Have Zero Values. Journal of Agricultural Economics, $48(1-3), 250-252$.

Battese, G.E., \& Broca, S.S. (1997). Functional Forms of Stochastic Frontier Production Functions and Models for Technical Inefficiency Effects: A Comparative Study for Wheat Farmers in Pakistan. Journal of Productivity Analysis, 8(4), 395-414.

Battese, G.E., \& Coelli, T.J. (1988). Prediction of Firm-Level Technical Efficiencies with a Generalized Frontier Production Function and Panel Data. Journal of Econometrics, 38(3), 387-399.

Battese, G.E., Malik, S.J., \& Gill, M.A. (1996). An Investigation of Technical Inefficiencies of Production of Wheat Farmers in Four Districts of Pakistan. Journal of Agricultural Economics, 47(1 - 4), 37-49.

Bravo-Ureta, B.E., \& Pinheiro, A.E. (1993). Efficiency Analysis of Developing Country Agriculture: A Review of the Frontier Function Literature. Agricultural and Resource Economics Review, 22(1), 88-101. 
Bravo-Ureta, B.E., Solís, D., López, V.H.M., Maripani, J.F., Thiam, A., \& Rivas, T. (2007).

Technical Efficiency in Farming: A Meta-Regression Analysis. Journal of Productivity Analysis, 27(1), 57-72.

Chen, Z., Huffman, W.E., \& Rozelle, S. (2009). Farm Technology and Technical Efficiency:

Evidence from Four Regions in China. China Economic Review, 20(2), 153-161.

Coelli, T.J. (1996). A Guide to Frontier Version 4.1: A Computer Program for Stochastic

Frontier Production and Cost Function Estimation: CEPA Working papers.

Coelli, T.J., \& Battese, G.E. (1996). Identification of Factors Which Influence the Technical Inefficiency of Indian Farmers. Australian Journal of Agricultural Economics, 40(2), 103-128.

Dlamini, S.I., Masuku, M.B., \& Rugambisa, J. (2012). Technical Efficiency of Maize Production in Swaziland: A Stochastic Frontier Approach. African Journal of Agricultural Research, 7(42), 5628-5636.

Fan, Z., Chai, Q., Huang, G., Yu, A., Huang, P., Yang, C., et al. (2013). Yield and Water Consumption Characteristics of Wheat/Maize Intercropping with Reduced Tillage in an Oasis Region. European Journal of Agronomy, 45, 52-58.

Farrell, M.J. (1957). The Measurement of Productive Efficiency. Journal of the Royal Statistical Society. Series A (General), 120(3), 253-290.

Feike, T., Doluschitz, R., Chen, Q., Graeff-Hönninger, S., \& Claupein, W. (2012). How to Overcome the Slow Death of Intercropping in the North China Plain. Sustainability, $4(10), 2550-2565$.

Feng, S. (2008). Land Rental, Off-Farm Employment and Technical Efficiency of Farm Households in Jiangxi Province, China. NJAS-Wageningen Journal of Life Sciences, 55(4), 363-378.

Førsund, F.R., Lovell, C.K., \& Schmidt, P. (1980). A Survey of Frontier Production Functions and of Their Relationship to Efficiency Measurement. Journal of Econometrics, 13(1), 5-25.

Francis, C.A. (1986). Multiple Cropping Systems. New York: Macmillan Publishing Company. Godfray, H.C.J., Beddington, J.R., Crute, I.R., Haddad, L., Lawrence, D., Muir, J.F., et al. (2010). Food Security: The Challenge of Feeding 9 Billion People. Science, 327(5967), 812818. 
Gorton, M., \& Davidova, S. (2004). Farm Productivity and Efficiency in the Cee Applicant Countries: A Synthesis of Results. Agricultural Economics, 30(1), 1-16.

Greene, W.H. (2008). The Econometric Approach to Efficiency Analysis The Measurement of Productive Efficiency and Productivity Growth (pp. 92-250). New York: Oxford University Press.

Guilkey, D.K., Lovell, C.K., \& Sickles, R.C. (1983). A Comparison of the Performance of Three Flexible Functional Forms. International Economic Review, 591-616.

Hardwick, T. (2007). The Efficiency of Maize Farming in Malawi: A Bootstrapped Translog Frontier. Cahiers d'Economie et Sociologie Rurales(82-83).

Hong, Y., Heerink, N., Jin, S., Berentsen, P., Zhang, L., \& van der Werf, W. (2017). Intercropping and Agricultural in China-Current State and Trends. Agriculture Ecosystems \& Environment, 244, 52-61.

Huang, C., Liu, Q., Heerink, N., Stomph, T., Li, B., Liu, R., et al. (2015). Economic Performance and Sustainability of a Novel Intercropping System on the North China Plain. PloS One, 10(8), e0135518.

Huang, Y., \& Kalirajan, K.P. (1997). Potential of China's Grain Production: Evidence from the Household Data. Agricultural Economics, 17(2), 191-199.

Jodha, N. (1980). Intercropping in Traditional Farming Systems. The Journal of Development Studies, 16(4), 427-442.

Knörzer, H., Graeff-Hönninger, S., Guo, B., Wang, P., \& Claupein, W. (2009). The Rediscovery of Intercropping in China: A Traditional Cropping System for Future Chinese Agriculture - a Review. In E. Lichtfouse (Ed.), Climate Change, Intercropping, Pest Control and Beneficial, Microorganisms (pp. 13-44). Dordrecht: Springer Netherlands.

Kumbhakar, S.C., Ghosh, S., \& McGuckin, J.T. (1991). A Generalized Production Frontier Approach for Estimating Determinants of Inefficiency in Us Dairy Farms. Journal of Business \& Economic Statistics, 9(3), 279-286.

Kumbhakar, S.C., \& Lovell, C.K. (2003). Stochastic Frontier Analysis. Cambridge: Cambridge University Press.

Li, L., Sun, J., Zhang, F., Guo, T., Bao, X., Smith, F.A., et al. (2006). Root Distribution and Interactions between Intercropped Species. Oecologia, 147(2), 280-290. 
Li, L., Sun, J., Zhang, F., Li, X., Yang, S., \& Rengel, Z. (2001). Wheat/Maize or Wheat/Soybean Strip Intercropping: I. Yield Advantage and Interspecific Interactions on Nutrients. Field Crops Research, 71(2), 123-137.

Li, L., Yang, S., Li, X., Zhang, F., \& Christie, P. (1999). Interspecific Complementary and Competitive Interactions between Intercropped Maize and Faba Bean. Plant and Soil, 212(2), 105-114.

Li, W., Li, L., Sun, J., Guo, T., Zhang, F., Bao, X., et al. (2005). Effects of Intercropping and Nitrogen Application on Nitrate Present in the Profile of an Orthic Anthrosol in Northwest China. Agriculture, Ecosystems \& Environment, 105(3), 483-491.

Lithourgidis, A., Dordas, C., Damalas, C., \& Vlachostergios, D. (2011). Annual Intercrops: An Alternative Pathway for Sustainable Agriculture. Australian journal of crop science, 5(4), 396.

Liu, Z., \& Zhuang, J. (2000). Determinants of Technical Efficiency in Post-Collective Chinese Agriculture: Evidence from Farm-Level Data. Journal of Comparative Economics, 28(3), 545-564.

Luo, F., Qi, S., \& Xiao, H. (2005). Landscape Change and Sandy Desertification in Arid Areas: A Case Study in the Zhangye Region of Gansu Province, China. Environmental Geology, 49(1), 90-97.

Ma, X., Heerink, N., Feng, S., \& Shi, X. (2017). Land Tenure Security and Technical Efficiency: New Insights from a Case Study in Northwest China. Environment and Development Economics, 22(3), 305-327.

Machado, S. (2009). Does Intercropping Have a Role in Modern Agriculture? Journal of Soil and Water Conservation, 64(2), 55A-57A.

Mao, L., Zhang, L., Li, W., van der Werf, W., Sun, J., Spiertz, H., et al. (2012). Yield Advantage and Water Saving in Maize/Pea Intercrop. Field Crops Research, 138, 11-20.

Matlon, P., \& Fafchamps, M. (1989). Crop Budgets in Three Agro-Climatic Zones of Burkina Faso. ICRISAT Progress Report. Hyderabad, India.

Mkamilo, G.S. (2004). Maize-Sesame Intercropping in Southeast Tanzania: Farmers' Practices and Perceptions, and Intercrop Perfromance. (Doctor Thesis), Wageingen University, The Netherlands.

Qu, F., Kuyvenhoven, A., Shi, X., \& Heerink, N. (2011). Sustainable Natural Resource Use in Rural China: Recent Trends and Policies. China Economic Review, 22(4), 444-460. 
Raseduzzaman, M., \& Jensen, E.S. (2017). Does Intercropping Enhance Yield Stability in Arable Crop Production? A Meta-Analysis. European Journal of Agronomy, 91, 25-33. Schmidt, P. (1985). Frontier Production Functions. Econometric Reviews, 4(2), 289-328. Seyoum, E., Battese, G.E., \& Fleming, E. (1998). Technical Efficiency and Productivity of Maize Producers in Eastern Ethiopia: A Study of Farmers within and Outside the SasakawaGlobal 2000 Project. Agricultural Economics, 19(3), 341-348.

Shaxson, L., \& Tauer, L.W. (1992). Intercropping and Diversity: An Economic Analysis of Cropping Patterns on Smallholder Farms in Malawi. Experimental Agriculture, 28(02), 211-228.

Shi, X., Heerink, N., \& Qu, F. (2007). Choices between Different Off-Farm Employment SubCategories: An Empirical Analysis for Jiangxi Province, China. China Economic Review, 18(4), 438-455.

Skinner, M.W., Kuhn, R.G., \& Joseph, A.E. (2001). Agricultural Land Protection in China: A Case Study of Local Governance in Zhejiang Province. Land Use Policy, 18(4), 329340.

Tan, S., Heerink, N., Kuyvenhoven, A., \& Qu, F. (2010). Impact of Land Fragmentation on Rice Producers' Technical Efficiency in South-East China. NJAS-Wageningen Journal of Life Sciences, 57(2), 117-123.

Tchale, H., \& Sauer, J. (2007). The Efficiency of Maize Farming in Malawi: A Bootstrapped Translog Frontier. Cahiers d'économie et sociologie rurales, 82-83.

Tian, W., \& Wan, G.H. (2000). Technical Efficiency and Its Determinants in China's Grain Production. Journal of Productivity Analysis, 13(2), 159-174.

Tong, P. (1994). Achievements and Perspectives of Tillage and Cropping Systems in China. Cropping System and Cultivation Technology, 4, 1-5. (in Chinese).

Vandermeer, J.H. (1989). The Ecology of Intercropping. Cambridge: Cambridge University Press.

Wadud, A., \& White, B. (2000). Farm Household Efficiency in Bangladesh: A Comparison of Stochastic Frontier and Dea Methods. Applied Economics, 32(13), 1665-1673.

Wang, H.-J., \& Schmidt, P. (2002). One-Step and Two-Step Estimation of the Effects of Exogenous Variables on Technical Efficiency Levels. Journal of Productivity Analysis, $18(2), 129-144$. 
Wang, Z., Zhao, X., Wu, P., He, J., Chen, X., Gao, Y., et al. (2015). Radiation Interception and Utilization by Wheat/Maize Strip Intercropping Systems. Agricultural and Forest Meteorology, 204, 58-66. doi: 10.1016/j.agrformet.2015.02.004

Wei, S., \& Wang, X. (2011). Productivity Growth, Technical Efficiency, and Technical Change in Chinas Soybean Production. African Journal of Agricultural Research, 6(25), 56065613.

Xu, X., \& Jeffrey, S.R. (1998). Efficiency and Technical Progress in Traditional and Modern Agriculture: Evidence from Rice Production in China. Agricultural Economics, 18(2), 157-165.

Yang, R., \& Liu, W. (2010). Nitrate Contamination of Groundwater in an Agroecosystem in Zhangye Oasis, Northwest China. Environmental Earth Sciences, 61(1), 123-129.

Yao, S., \& Liu, Z. (1998). Determinants of Grain Production and Technical Efficiency in China. Journal of Agricultural Economics, 49(2), 171-184.

Yu, Y., Makowski, D., Stomph, T.-J., \& van der Werf, W. (2016). Robust Increases of Land Equivalent Ratio with Temporal Niche Differentiation: A Meta-Quantile Regression. Agronomy Journal, 108(6), 2269-2279.

Yu, Y., Stomph, T.-J., Makowski, D., \& van der Werf, W. (2015). Temporal Niche Differentiation Increases the Land Equivalent Ratio of Annual Intercrops: A MetaAnalysis. Field Crops Research, 184, 133-144.

Zhang, F., \& Li, L. (2003). Using Competitive and Facilitative Interactions in Intercropping Systems Enhances Crop Productivity and Nutrient-Use Efficiency. Plant and Soil, 248(1-2), 305-312.

Zhang, J. (2007). Barriers to Water Markets in the Heihe River Basin in Northwest China. Agricultural Water Management, 87(1), 32-40.

Zhang, L., Heerink, N., Dries, L., \& Shi, X. (2013). Water Users Associations and Irrigation Water Productivity in Northern China. Ecological Economics, 95, 128-136.

Zhu, Y., Chen, H., Fan, J., Wang, Y., Li, Y., Chen, J., et al. (2000). Genetic Diversity and Disease Control in Rice. Nature, 406(6797), 718-722. 


$$
\text { Chapter } 4
$$

Socio-economic factors influencing the

$$
\text { adoption of intercropping - Evidence }
$$

\author{
from northwest China
}




\title{
4. Socio-economic factors influencing the adoption of intercropping - Evidence from northwest China ${ }^{25}$
}

\begin{abstract}
Intercropping, i.e. the cultivation of crop species mixtures, can potentially reduce pressure on land resources by generating higher crop yields through exploitation of complementarities between species. Although intercropping is practiced on a non-negligible proportion of China's arable land, little is known about the factors that influence farmers' decisions to use intercropping systems. In this study we examine the impact of farm household assets and household characteristics like risk aversion on the adoption of traditional as well as new types of intercropping, using primary data collected among 299 farmers in Gaotai county, northwest China. We find that natural assets (land and irrigation water) are important determinants of the use of intercropping, while human assets (including labor-land ratios) and financial assets do not have a significant effect. Neither do risk aversion perceptions of farm households play a significant role. Availability of machinery does not negatively affect the area under intercropping, but has a significant positive effect on the adoption of one novel intercrop type (cumin/maize). We conclude by drawing inferences regarding some (often unintended) effects on natural resource use of recent agricultural policies and other major ongoing trends.
\end{abstract}

Keywords: Intercropping, adoption, farm size, machinery, China

\footnotetext{
${ }^{25}$ This chapter has been submitted to the Ecological Economics, as Hong, Y., Heerink, N., and van der Werf, W. 'Socioeconomic factors influencing the adoption of intercropping - Evidence from northwest China'.
} 


\subsection{Introduction}

Intercropping refers to the cultivation of two or more crop species simultaneously in the same field for the whole or a part of their growing period (Vandermeer, 1989). As an ancient and traditional cropping system, intercropping has been practiced worldwide (Francis, 1986; Lithourgidis et al., 2011). It has been shown that intercropping can achieve higher yields per unit land (Zhang and Li, 2003; Lithourgidis et al., 2011; Yu et al., 2015), counteract resource (e.g. soil) degradation and improve soil fertility (e.g. nitrogen fixation in legume intercropping) (Willey, 1979a; Lithourgidis et al., 2011), and is often less risky than monocropping (Clawson, 1985; Horwith, 1985). In addition, intercropping holds the promise of providing benefits to smallholders through increased crop yields and income as well as improved resource use (Himmelstein et al., 2017).

Intercropping has been practiced in China for thousands of years, and is still popular in some regions across the country in present-day agriculture (Knörzer et al., 2009; Hong et al., 2017). Differences in agro-ecological conditions may explain regional variation in intercropping practices across China. Intermediate heat resources are a major reason for use of relay intercropping in parts of Gansu and in northwest Liaoning (Li et al., 2001; Mao et al., 2015; Wang et al., 2015). In relay intercropping, two crop species are sown and harvested at different times with only partial overlap in growing period, allowing use of a greater portion of the growing season and therefore enabling increased yield as compared to sole crops (Mao et al., 2015; Yu et al., 2016). Improvement of soil fertility and suppression of weeds are among the reasons why intercropping systems like wheat/maize/sweet potato and sugarcane/soybean are used in the southwest (Yan et al., 2010; Wang et al., 2015) and south of China (Che et al., 2011; Li et al., 2013). Suppressing rice blast disease and allowing greater fertilizer input in a system with a long straw rice variety are the main incentives for farmers to 
apply rice / rice intercropping (using a mixture of a traditional and modern rice varieties) in southwest China (Zhu et al., 2000; Revilla-Molina et al., 2009; Han et al., 2016).

Socio-economic factors are likely to play an important role as well, but only few researchers have examined their importance. Feike et al. (2009) found that intercropping systems in the North China Plain were encouraged by land fragmentation and the 'Green Belt' policy ${ }^{26}$ and discouraged by rising opportunity costs of rural labor and rapid mechanisation. Shi et al. (2014) found that seed maize and vegetables with a higher profitability replaced the traditional maize / wheat intercrops in the Heihe River Basin in Gansu province since 2000. Huang et al. (2015) found that farmers in Quzhou county in the North China Plain were able to generate incomes that exceed local off-farm incomes by integrating watermelon into the traditional wheat and maize double cropping system, creating a tripartite intercropping system in which watermelon overlaps in growing period with both wheat and maize, while wheat and maize are grown sequentially (Huang et al., 2015). Hong et al. (2017) found that the share of arable land under intercropping in 63 villages in six provinces across China is positively related to the number of family labourers and negatively associated with machinery power owned by the household.

The limited available literature on the role of socio-economic factors in the adoption of intercropping in China and elsewhere is generally of an exploratory nature. It lacks a generally agreed-upon theoretical framework and disregards the fact that some farmers adopt more than one intercropping system. This study is a first step to fill this gap. We develop a theoretical framework for the adoption of intercropping, and use a case study to empirically investigate the factors affecting the adoption of intercropping at farm level. We apply multiple regression

\footnotetext{
26 The 'Green Belt' policy, also named the 'Green Great Wall', is a series of human-planted wind-breaking forest strips (shelterbelts) in northern China, designed to hold back the expansion of the Gobi Desert. In the North China Plain, the policy encourages the establishment of 10 to 50 meter wide strips of trees along major roads and farms. https://en.wikipedia.org/wiki/Three-North_Shelter_Forest_Program (accessed at 18.03.2018)
} 
analysis to examine explanatory factors related to adoption of intercropping as an overarching cropping strategy and also to analyse adoption of particular intercropping systems. The empirical analysis is based on detailed survey data collected among 299 household farms in 2014 in Gaotai County, Zhangye City, Gansu province, China. The main intercropping systems in this region are wheat / maize, cumin / maize and seed watermelon / maize.

\subsection{Theoretical framework}

Based on the available literature, we classify the main socioeconomic factors affecting the adoption of intercropping into four groups: Yield gains, risk reduction, labour costs, and human assets.

\subsubsection{Yield gains}

The main advantage of intercropping is the more efficient utilization of land and other resources, resulting in land equivalent ratios that are generally above one (Willey, 1979a; Li et al., 1999; Lithourgidis et al., 2011; Yu et al., 2015). A land equivalent ratio above one means that it would require additional land to produce the crop yields produced on a unit area of intercrop using sole crops (Mead and Willey, 1980; Yu et al., 2016). Yield gains occur because growth resources such as light, water and nutrients are more completely absorbed by the intercrop over time and space. Dakora (1997) documented that intercropping is a common practice in many areas of Africa faced with declining land size and increasing food needs, because intercropping gives higher yields than the same crops grown as monoculture. Yields gains imply higher profits if the value of a yield gain exceeds the costs of additional inputs used in growing the intercrop. Huang et al. (2015) found that the gross margin per unit area of the wheat / maize / watermelon system exceeds that of wheat / maize double cropping in 
Quzhou county, China. The higher yield and profit per unit of land are likely to be an important incentive for farmers to adopt intercropping.

\subsubsection{Risk reduction}

An important advantage of intercropping is that it can substantially reduce the risk of crop damage or total crop failure as compared to sole cropping (Horwith, 1985; Machado, 2009). Different crop species (or even different varieties of the same species) respond differently to weather extremes and to pest and disease outbreaks. In the case that one species in an intercrop is affected, the resources that become available through the failure of that species can be used by the surviving species (Horwith, 1985; Lithourgidis et al., 2011). In several parts of Africa and south Asia, adverse conditions such as disease, drought or pest attacks frequently cause crop failures. Farmers in these regions tend to reduce the risk of total crop failure by growing more than one crop in their field (Clawson, 1985; Horwith, 1985).

Mkamilo et al. (2004) claims that the risk of crop failure associated with growing sesame in pure stand is an important reason for adding maize to sesame in southeast Tanzania. Kassie et al. (2013) found that in the presence of pests and diseases, farmers in Tanzania tend to adopt technologies and practices that involve smaller cash outlays as well as lower risks (such as legume intercropping). These findings suggest that, even when yields of mono-cropping and multi-cropping would be similar, lower risk involved in intercropping may be an important motivation for the adoption of intercropping. In the case of northwest China, land use studies based on empirical land equivalent ratios from household and farm survey indicate that the use of intercropping results in substantial increases in grain production at the watershed level (Gou et al., 2017). 


\subsubsection{Labour costs}

Intercropping practices are usually more labour-intensive than sole crops, because options for using machinery are usually fewer in intercropping. When wages are rising, famers are therefore less likely to practice intercropping. Household access to alternative sources of employment, and the labor return from it, are likely to negatively influence the adoption of intercropping. Off-farm activities may divert time and effort away from agricultural activities, reducing labor and other inputs. The opportunity costs of rural labor may increase due to rising off-farm wages. However, if the returns to labor used in (inter)cropping activities exceed that of off-farm wages (corrected for transaction costs like the cost of searching an offfarm job), farmers are more likely to spend labor on (inter)cropping activities. Huang et al. (2015) argue that one of the main reasons for farmers in Quzhou county, China for adopting the wheat / maize / watermelon intercropping system is its relatively high return per labor hour as compared to off-farm wages.

\subsubsection{Human assets}

Due to its spatial arrangements of planting, weeding and harvesting, intercropping requires more care and a larger sense of discrimination as compared to sole crops (Jodha, 1980). Usually family workers do better on such criteria than hired workers. So the presence of family labor may have a positive effect on the adoption of intercropping. The age of laborers may play a role as well, because intercropping systems usually require much farming experience. But in the case of relatively new intercropping techniques, older farmers may be less aware of the technology (due to access to information) or less willing to adopt it (due to risk aversion or the relatively large labor requirements). Education often plays an important role in allocative ability, i.e. choosing which crop to plant and assigning which piece of land 
to which crop (Feder et al., 1985). Thus, human assets are likely to play an important role in the decision making on intercropping.

\subsubsection{An integrated framework}

Yield gains, labor costs and risk reduction reflect two important goals of smallholder decision making, i.e. income maximization and risk aversion. In the remainder of this paper we assume that these goals are the main driving forces in decision making on the (dis)adoption of intercropping. Arable farmers have three main options for increasing incomes and reducing risks: Mono-cropping, intercropping, and off-farm employment. Farmers are expected to choose a combination of these three options that gives the highest utility, where utility is a weighted average of (discounted) mean income and its variation over time, given a household's assets and characteristics and prevailing (agricultural and off-farm) market conditions.

Figure 4.1 presents a schematic representation of the analytical framework that we use in this study. It is derived from frameworks used for analysing sustainable livelihood strategies (see e.g. Ellis, 2000; Scoones, 2015), with a focus on economic factors affecting the adoption of intercropping. Agro-ecological conditions as well as relevant policies and institutions that may affect smallholder activity choices, but tend to show little variation within local communities, are omitted for reasons of simplicity. 


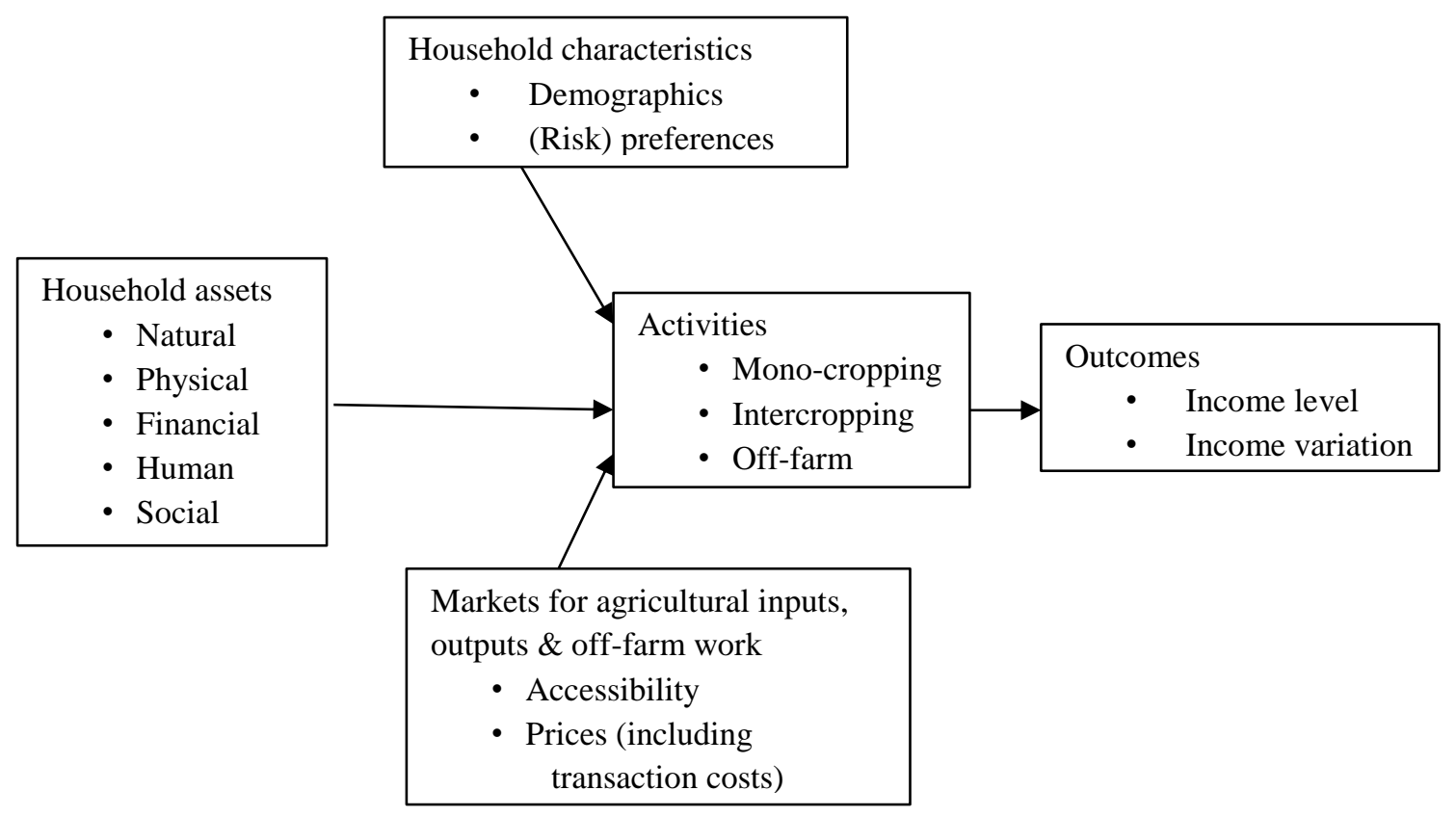

Figure 4.1 Analytical framework of adoption of intercropping

Figure 4.1 shows at the right hand side the household's income level and its variation over time as outputs of the chosen activities (i.e. combination of mono-cropping, intercropping and off-farm work). As in the sustainable livelihoods framework, the five main types of assets that a household possesses, i.e. natural, physical, financial, human and social capital, are assumed to be major determinants of the portfolio of activities that a household employs to maximise its utility derived from income and its variation over time. Household characteristics, including demographic features (like the share of children in a household) and preferences (like risk aversion), may constitute important limiting or facilitating factors. Moreover, a household's access to markets for agricultural inputs and outputs and for off-farm employment, and the prevailing effective prices (taking into account transaction costs) on those markets, affect the income that can be earned from the allocation of household assets to different activities.

The framework presented in Figure 4.1 shows that the yield and income gains and the risk reduction inherent to intercropping, as compared to mono-cropping and off-farm work, drive the adoption/non-adoption decisions of households given (1) their preferences and other 
characteristics, (2) their human and other assets, and (3) levels of access to, and effective prices on, relevant markets. This integrated framework is at the basis of the empirical model that we estimate in this paper. 


\subsection{Model specification and estimation strategy}

\subsubsection{Model specification}

The model that we use for the empirical analysis is specified as:

$$
I C_{i}=c_{0}+\sum_{j=1}^{4} \sum_{k=1}^{n_{j}} c_{j k} A S_{j k i}+\sum_{l=1}^{3} c_{l} H C_{l i}+\sum_{m=1}^{2} c_{m} V D_{m i}+
$$

$\varepsilon_{i}$

where:

$I C_{i}=$ Intercropping indicator for household $i$

$A S_{j k i}=$ Indicator $j$ of $k$-th asset for household $i$

$\mathrm{HC}_{l i}=$ Household characteristic indicator $l$ for household $i$.

$V D_{m i}=$ Dummy variable that equals one if household $i$ lives in village $m$.

$c_{0}, c_{j k}, c_{l}, c_{m}=$ Unknown coefficients

$\varepsilon_{i}=$ Disturbance term with standard properties

We use four different intercropping indicators as dependent variables: The total area planted with intercrops and the areas planted with wheat/maize, cumin/maize and seed watermelon/maize (the three main intercrops in the region), respectively. Thus, we estimate parameter values for four models.

Five different types of assets are distinguished in the analytical framework shown in Figure 4.1: Natural, physical, financial, human and social capital. We use three indicators of natural capital for explaining intercropping: contracted land size, number of plots, and irrigation water. Households with larger farms are more likely to spend more time on arable farming for making a living. As they are relatively limited in using off-farm employment as a risk- 
spreading device, they are more likely to rely on intercropping and related sustainable agricultural practices to spread risk (Ngwira et al., 2014). Farm size consists of contracted land and net rented-in land. Contracted land refers to the land allocated by the village committee to a household. Households have long-term use rights to contracted land, although land reallocations may sporadically take place (see e.g. Ma et al., 2015). Land rentals, on the other hand, usually take place for relatively short periods. Land rental decision may be taken jointly with cropping decision. Hence, we use contracted land size to represent the land size asset. An important other dimension of land assets, besides contracted land size, is the degree of land fragmentation. The number of plots, a commonly used indicator of fragmentation, can have a positive as well as a negative impact on the adoption of intercropping. Scale economies through mono-cropping are more difficult to realize when a farm of a given size consist of a large number of different plots. On the other hand, land fragmentation may serve as a means for risk reduction (Charlesworth, 1983; Ilbery, 1984). When land quality or the micro agro-climate is not homogeneous, the scattering of land plots can reduce the risk of loss from flood, drought, fire, pests, diseases or other threats, and farmers can diversify their crops and crop varieties across different growing conditions. The need for risk reduction through intercropping therefore will be less if farmers use land fragmentation as a risk-spreading device. Availability of irrigation water is anticipated to have a positive impact on the adoption of intercropping. Relay intercropping systems tend to have higher water demand than sole crop systems because of the longer total growth duration. Nevertheless, they can be water use efficient if water use is calculated per unit grain (Yin et al., 2015). In some parts of Gansu province, wheat-maize intercropping is prohibited by the local government because the system uses too much irrigation water (Mao et al., 2012). Availability of irrigation water is measured in this study by the weighted average of the number of irrigation rounds on a farm, using land shares planted with each crop as weights. 
Possession of agricultural machinery is an important element of physical capital that may affect the choice between mono-cropping, intercropping and off-farm employment. Specifically designed machinery for intercropping is almost non-existent, so possession of agricultural machinery is expected to have a negative impact on the adoption of intercropping unless machinery used in mono-crops can also be used in intercrops. On the other hand, it may be argued that rural households possessing more agricultural machinery are more likely to specialize in agriculture and that intercropping may be practiced as a risk spreading device on part of the land by households specializing in agriculture. The survey data set that we use for this study unfortunately contains no information on possession of agricultural machinery or other physical assets. It does have data on expenditures on oil used for agricultural machinery. To minimize potential endogeneity problems, we use a dummy variable that indicates non-zero expenditures on agricultural machinery oil as a proxy variable for the possession of agricultural machinery.

We use debt as an indicator of financial assets. Capital in the form of either accumulated savings or access to capital markets is required to finance the use of variable inputs and make investments in agricultural production (Feder et al., 1985). Household debt, as a rough proxy for capital, can be positively related to the adoption of intercropping. Heavily indebted farmers may be less willing to use technologies from which the benefit is relatively uncertain (Kebede et al., 1990). Given that intercropping has been practiced for decades in the region and its yield tends to be relatively stable (Li et al., 2005), indebted famers are more likely to rely on intercropping when off-farm opportunities are scarce.

We use three indicators of human assets: labor-land ratios, education and age. Labor-land ratio is a proxy for family labor availability. It is expected to affect intercropping adoption positively, as intercropping requires relatively more labor, more care and a larger sense of discrimination as compared to sole crops. Education, proxied by formal schooling of head of 
household, can be either positively or negatively related to the adoption of intercropping. Higher education provides better opportunities to acquire knowledge about intercropping practices and learn from applying such practices. But it also increases the likelihood of finding off-farm work. The effect of age of the farmer on adoption of intercropping can also be either negative or positive. On the one hand, the age of a farmer will have a negative effect on the likelihood of adoption as older farmers may be less aware of new intercropping technologies (e.g. cumin / maize intercropping), and may not be able to provide the extra physical labor required by such technologies (Nkonya et al., 1997; Ouma and De Groote, 2011; Kassie et al., 2013). On the other hand, elder farmers tend to have more experience with traditional intercropping systems and be better able to grasp their yield gains (Bekele and Drake, 2003; Ngwira et al., 2014).

The fifth type of assets distinguished in Figure 4.1 is social capital. Unfortunately, the data set that we use for this study does not contain any suitable indicators of social capital. We therefore focus our analysis on the other four types of household assets.

As regards household characteristics, we use three different indicators: gender, dependency ratio and risk aversion. Gender is measured by the share of males among those in the household who are of working age (between 16 to 65). Some agricultural activities, especially those requiring much carefulness, are typically carried out by females, while other activities are generally carried out by males. Gender may therefore affect the adoption of intercropping, but the direction of its impact is a priori unknown. The involvement of females in intercropping and other agricultural activities may be limited in households with a high dependency ratio, as taking care of dependents is commonly regarded a task for women. When household production decisions are affected by consumption choices, households with high dependency ratios may meet their relatively high food demands by growing a larger land share with maize-based intercrops. Another household characteristic that may play an 
important role in intercropping decisions is its degree of risk aversion. Intercropping is known to reduce the risk of crop failure as compared to sole cropping (see Section 4.2.2). Farmers with a high degree of risk aversion are therefore more likely to grow intercrops, keeping other factors constant.

Biophysical conditions and the market environment (for credit, machinery services, agricultural output, off-farm employment) of farm households usually show little variation within villages. The same holds for agricultural policies, rules and regulations and rural institutions in general. We use village dummies as proxies for these factors that are likely to vary between villages but usually show little intra-village variation.

\subsubsection{Estimation strategy}

The data set that we use contains a substantial number of zero observations for the four dependent variables. Tobit models are an appropriate method to address significant censoring (i.e., large numbers of zeros) in dependent variables. Because linear models ignore this censoring, OLS estimation leads to biased and inconsistent estimates (Tobin, 1958; Greene, 2003). Studies that compared the results of OLS and Tobit, however, found that the conclusions drawn by applying the two methods are very similar (e.g. (Foster and Kalenkoski, 2013). We therefore applied both methods. Because they have a straightforward interpretation, we present OLS results in the main text and the results of Tobit models (as a robustness check) in the Appendix.

The land area planted with crops consist of contracted land and net rented-in land. Contracted land tends to be stable over a longer period, but land rental decision are likely to be endogenous. Farmers with much experience in intercropping may rent additional land for expanding their intercropping activities. Unfortunately, there are no variables in the data set that could be used as instruments for land rentals in an instrumental variable (IV) model. 
Thus, we present regression results with and without land rentals as explanatory variable in order to examine the extent to which the inclusion of this potentially endogenous variable affects the outcomes and the main conclusions.

\subsection{Data and descriptive statistics}

\subsubsection{Data collection}

During the period August - November 2014, survey teams from Northwest Agricultural and Forestry University and the University of Chinese Academy of Sciences conducted a survey in the Heihe River Basin in Gansu province and Inner-Mongolia. The Heihe River is an inland river that originates in the Qilian Mountains in Qinghai Province, flows northwards through Gansu Province and ends in Juyanhai Lake in the Inner Mongolia Autonomous Region. The main goal of the survey was to assemble information on farm livelihoods and water use in different parts of the river basin. Data were collected on use of inputs and outputs in agricultural production, consumption and expenditure, and farmers' attitude towards water policy.

The data that we use in this study were obtained from a sub-sample for Luocheng township in Gaotai County Zhangye City, Gansu Province and an additional survey, conducted by the first author, in the same township. Zhangye City is an oasis located midstream of the Heihe River. The annual precipitation is $89-283 \mathrm{~mm}$, with 70 to $90 \%$ concentrated in the period July to September, while evaporation is about $1700 \mathrm{~mm}$ per year (Zhang, 2007), resulting in a desert climate type. Due to the availability of irrigation water from the Heihe River, the flat and fertile land and abundant sunshine, the area has become a major grain (seed) and vegetable (seed) base in Gansu Province (Luo et al., 2005; Yang and Liu, 2010; Zhang et al., 2013). 
Gaotai county (Figure 4.2), between $98^{\circ} 57^{\prime}-100^{\circ} 06^{\prime} \mathrm{E}, 39^{\circ} 03^{\prime}-39^{\circ} 59^{\prime} \mathrm{N}$, is one of the six administrative counties in Zhangye City. Wheat and maize are the main staple food crops, while soybean, cotton, rapeseed and seed crops (e.g. seed maize and seed melon) are grown as cash crops. Wheat intercropped with maize and cash crops (e.g. cumin and seed watermelon) intercropped with maize are the main intercropping systems in the region. Wheat/maize is the conventional practice that has been used for 40 years (Li et al., 2001), seed watermelon/maize was started in the early 2000s and cumin/maize was introduced in recent years.

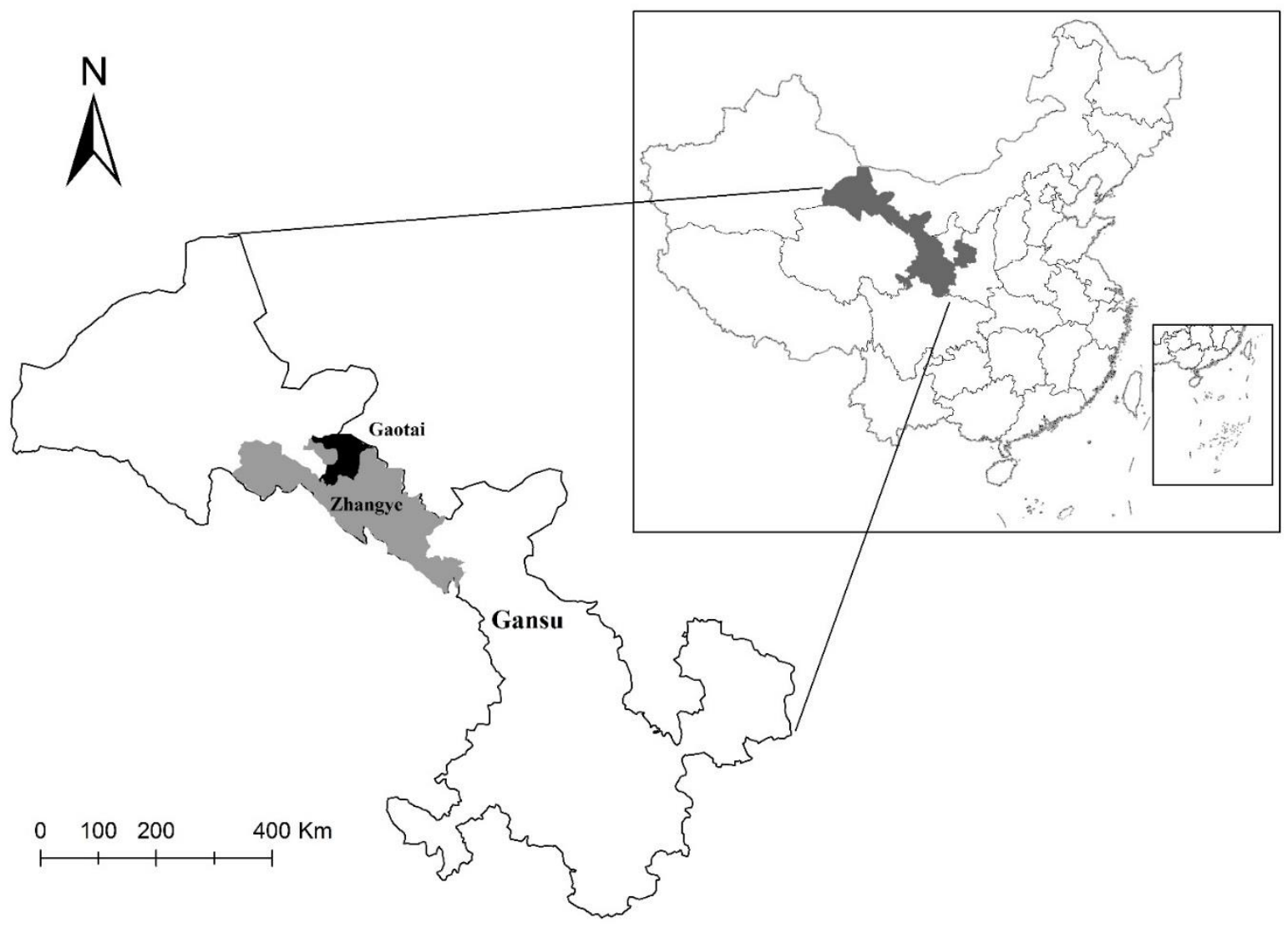

Figure 4.2 Location of Gaotai County, Zhangye City, Gansu Province, China

We selected the Luocheng township to collect additional information. Intercropping has historically been popular in this township and are still important, Three villages in Luocheng township were randomly selected. Within each village, interviewees were randomly selected among the households that were present in the village at the time of the farm survey. In total, 
320 farm households ${ }^{27}$ were interviewed about the 2013 agricultural season. Out of these 320 household heads, 21 farmers did not provide complete information on major variables in our analysis, like irrigation water input. They were excluded from the sample. The sample used for the analysis therefore included 299 households.

\subsubsection{Descriptive statistics}

The definition of the variables used in the regression analysis and their descriptive statistics are presented in Table 4.1. Among the 299 farm households, 277 (92.6\%) used intercropping. On average, farmers allocated $62 \%$ of their land to intercropping. Wheat / maize is the most popular type of intercropping, it was grown on $28 \%$ of the farmland; the share of land planted with cumin / maize intercropping equals $25 \%$ and the share planted with seed watermelon / maize equals $9 \%$ of the total land cultivated by farmers in the sample, on average.

Table 4.1 Variable definitions and descriptive statistics

\begin{tabular}{|c|c|c|c|c|c|c|c|}
\hline & & \multicolumn{4}{|c|}{ All observations } & \multirow{2}{*}{$\begin{array}{l}\text { Adopter } \\
\text { Mean }\end{array}$} & \multirow{2}{*}{$\begin{array}{l}\text { Non- } \\
\text { adopter } \\
\text { Mean }\end{array}$} \\
\hline $\begin{array}{l}\text { Variables } \\
\text { Dependent } \\
\text { variable }\end{array}$ & Description & Mean & S.D. & Min. & Max. & & \\
\hline $\begin{array}{l}\text { Intercropping } \\
\text { area }\end{array}$ & $\begin{array}{l}\text { Cultivated area of intercropping } \\
(\mathrm{mu})\end{array}$ & 6.7 & 4.0 & 0 & 25 & 7.2 & 0 \\
\hline Wheat/maize area & $\begin{array}{l}\text { Cultivated area of wheat/maize } \\
\text { intercropping }(\mathrm{mu})\end{array}$ & 2.7 & 2.4 & 0 & 14 & 2.9 & 0 \\
\hline $\begin{array}{l}\text { Cumin/maize } \\
\text { area }\end{array}$ & $\begin{array}{l}\text { Cultivated area of cumin/maize } \\
\text { intercropping }(\mathrm{mu})\end{array}$ & 3.0 & 3.1 & 0 & 15 & 3.2 & 0 \\
\hline $\begin{array}{l}\text { Seed watermelon } \\
\text { /maize area }\end{array}$ & $\begin{array}{l}\text { Cultivated area of Seed } \\
\text { watermelon/maize area } \\
\text { intercropping }(\mathrm{mu})\end{array}$ & 1.0 & 1.5 & 0 & 10 & 1.1 & 0 \\
\hline Proportion & $\begin{array}{l}\text { Share of cultivated land under } \\
\text { intercropping }\end{array}$ & 0.62 & 0.28 & 0 & 1 & 0.67 & 0 \\
\hline
\end{tabular}

\footnotetext{
${ }^{27}$ For those household heads that were absent during our interview, we interviewed one of the other family members with sufficient knowledge about farming practices.
} 


\begin{tabular}{|c|c|c|c|c|c|c|}
\hline $\begin{array}{l}\text { Wheat/maize } \\
\text { proportion }\end{array}$ & $\begin{array}{l}\text { Share of cultivated land under } \\
\text { wheat/maize intercropping }\end{array}$ & 0.28 & 0.27 & 0 & 1 & 0.31 \\
\hline $\begin{array}{l}\text { Cumin/maize } \\
\text { proportion }\end{array}$ & $\begin{array}{l}\text { Share of cultivated land under } \\
\text { cumin/maize intercropping }\end{array}$ & 0.25 & 0.23 & 0 & 1 & 0.27 \\
\hline $\begin{array}{l}\text { Seed watermelon/ } \\
\text { maize proportion }\end{array}$ & $\begin{array}{l}\text { Share of cultivated land under } \\
\text { seed watermelon/maize } \\
\text { intercropping }\end{array}$ & 0.09 & 0.15 & 0 & 1 & 0.10 \\
\hline
\end{tabular}

\section{Natural assets}

Area of contracted land (mu)

$\begin{array}{lllll}10.7 & 5.6 & 1.5 & 45 & 11.0^{* * * *}\end{array}$

Net rented-in

Area of net rented-in land (mu)

$3.4 \quad-35$

12

0.33

0.23

Number of plots

Total number of land plots

94.1

25

$9^{* * *}$

Irrigation water

Average rounds of irrigation

$\begin{array}{lll}5.2 & 1.9 & 0.52\end{array}$

$11 \quad 5.3^{*}$

Physical assets

Agricultural machinery

Financial assets

Household debt ${ }^{\mathrm{a}}$

Natural logarithm of total household debt

\section{Human assets}

Labor-land ratio

Ratio of family labor to contracted land

Education

Age

\section{Household} characteristics

Gender

Dependency ratio

Risk aversion ${ }^{\mathrm{b}}$ 0 , otherwise school, $3=$ middle school, 4=college year, $7=$ above 70 year
$1=$ expenditure of agricultural machinery oil is larger than zero,

$0.76 \quad 0.43$

0

$10.79^{* * *}$

0.36

Average education attainment of all labor force members in the family; $1=$ illiterate, $2=$ primary Average age of all labor force members in the family; $0=0-10$ year, $1=10-20$ year, $2=20-30$ year, $3=30-40$ year, $4=40-50$ year, $5=50-60$ year, $6=60-70$

$2.2 \quad 0.59$

0.05

1.5

$0.29^{* * *}$

0.41

$5.4 \quad 5.2$

0

13.5

5.5

$4.3 \quad 0.92$

2.3

7.0

$4.3^{* *}$
Share of males among household laborers

Ratio of dependent members (age 0-14 and over 64 ) to household size Answer to statement about technology adoption, $\begin{array}{llllll}0.54 & 0.11 & 0 & 1 & 0.54 & 0.53\end{array}$

$\begin{array}{llllll}0.27 & 0.21 & 0 & 0.67 & 0.27^{*} & 0.19\end{array}$

$\begin{array}{llllll}2.8 & 1.4 & 1 & 5 & 2.8 & 2.6\end{array}$ 
$1=$ totally disagree, $2=$ disagree,

$3=$ no idea, $4=$ agree, $5=$ totally

agree

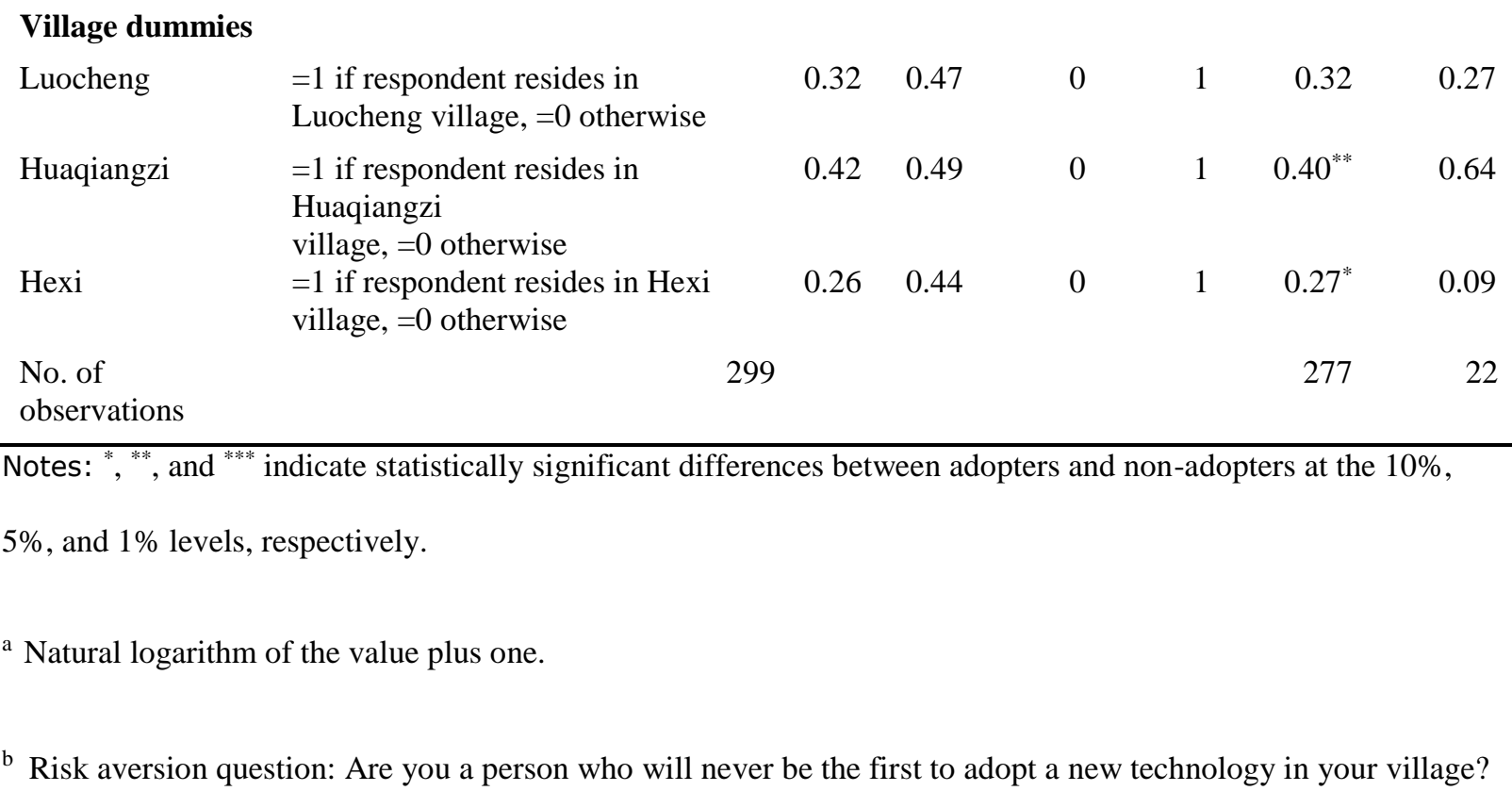

The last two columns of Table 4.1 present mean values for adopters and non-adopters ${ }^{28}$, and show whether these differences are statistically significant. On average, farm households that used intercropping have more contracted land, a larger number of plots, lower labor-land ratios and more irrigation rounds, as compared to households that did not practice intercropping. Moreover, adopters are more likely to use machinery, have a slightly higher level of education, are younger and have a higher dependency ratio than non-adopters. The net rented-in land, household debt, gender ratio and level of risk aversion do not significantly differ between the two groups.

Although the simple comparisons presented in Table 4.1 reveal some significant differences between adopters and non-adopters, they do not provide information on conditional effects for

\footnotetext{
${ }^{28}$ Adopter refers to a household that had at least one plot used intercropping.
} 
given values of other variables affecting adoption. In the following section, we present and discuss such conditional effects based on the model specified in equation (1).

\subsection{Results and discussion}

Model (1) was estimated using OLS with and without net rented-in land as explanatory

variable. Regression results for intercropping as a whole are presented in Table 4.2.

Table 4.2 Regression results for total intercropping area (OLS)

\begin{tabular}{|c|c|c|}
\hline \multirow[t]{3}{*}{ Explanatory variables } & \multicolumn{2}{|l|}{ Dependent variable } \\
\hline & Area of intercropping & \\
\hline & With land rental & Without land rental \\
\hline \multicolumn{3}{|l|}{ Natural assets } \\
\hline Contracted land & $\begin{array}{r}0.430^{* * *} \\
(0.051)\end{array}$ & $\begin{array}{r}0.216^{* * *} \\
(0.044)\end{array}$ \\
\hline Number of plots & $\begin{array}{l}0.128^{* *} \\
(0.055)\end{array}$ & $\begin{array}{c}0.335^{* * * *} \\
(0.049)\end{array}$ \\
\hline Irrigation & $\begin{array}{r}0.410^{* * * *} \\
(0.092)\end{array}$ & $\begin{array}{r}0.365^{* * *} \\
(0.099)\end{array}$ \\
\hline \multicolumn{3}{|l|}{ Physical assets } \\
\hline Machinery & $\begin{array}{l}0.960^{* *} \\
(0.420)\end{array}$ & $\begin{array}{r}1.435^{* * *} \\
(0.447)\end{array}$ \\
\hline \multicolumn{3}{|l|}{ Financial assets } \\
\hline Household debt & $\begin{array}{l}-0.001 \\
(0.032)\end{array}$ & $\begin{array}{r}-0.007 \\
(0.034)\end{array}$ \\
\hline \multicolumn{3}{|l|}{ Human assets } \\
\hline Labor-land ratio & $\begin{array}{l}-1.074 \\
(1.069)\end{array}$ & $\begin{array}{l}-1.636 \\
(1.149)\end{array}$ \\
\hline Education & $\begin{array}{r}-0.101 \\
(0.317)\end{array}$ & $\begin{array}{r}0.100 \\
(0.340)\end{array}$ \\
\hline Age & $\begin{array}{r}-0.139 \\
(0.239)\end{array}$ & $\begin{array}{l}-0.129 \\
(0.258)\end{array}$ \\
\hline \multicolumn{3}{|l|}{$\begin{array}{l}\text { Household } \\
\text { characteristics }\end{array}$} \\
\hline Gender & $\begin{array}{l}-1.231 \\
(1.349)\end{array}$ & $\begin{array}{l}-2.326^{*} \\
(1.443)\end{array}$ \\
\hline Dependency ratio & $\begin{array}{r}-0.878 \\
(0.810)\end{array}$ & $\begin{array}{l}-1.104 \\
(0.872)\end{array}$ \\
\hline Risk aversion & $\begin{array}{r}-0.023 \\
(0.113)\end{array}$ & $\begin{array}{l}-0.084 \\
(0.121)\end{array}$ \\
\hline \multicolumn{3}{|l|}{ Village dummies } \\
\hline Huaqiangzi & $\begin{array}{l}-0.535 \\
(0.397)\end{array}$ & $\begin{array}{l}-0.802^{*} \\
(0.425)\end{array}$ \\
\hline
\end{tabular}




\begin{tabular}{lrr} 
Hexi & $1.149^{* *}$ & $1.207^{* * *}$ \\
& $(0.415)$ & $(0.447)$ \\
Net rented-in land & $0.428^{* * *}$ & \\
& $(0.062)$ & 1.015 \\
Constant & -0.024 & $(2.133)$ \\
No. of observations & $(1.985)$ & 299 \\
$\mathrm{R}^{2}$ & 299 & 0.534 \\
Adjusted $\mathrm{R}^{2}$ & 0.600 & 0.513 \\
\hline
\end{tabular}

${ }^{*},{ }^{* *}$ and ${ }^{* * *}$ indicate statistical significance at $10 \%, 5 \%$ and $1 \%$ levels, respectively.

Standard errors are reported in parentheses.

As expected, contracted land has a significant and positive impact on intercropping. A one mu increase in contracted land is found to increase the land area under intercropping by $0.43 \mathrm{mu}$ on average. This increase is smaller than the average share of land under intercropping, which equalled 0.62 for the farm households in the sample (Table 4.1). As a consequence, contracted land area has a significant negative impact on the share of land under intercropping (see Table A4.1 in the Appendix). Rented-in land is found to have a similar relationship with intercropping, with $0.43 \mathrm{mu}$ of intercropping on average on each additional mu of rented land. The number of plots also has a significant positive effect on the use of intercropping. This finding suggests that scale disadvantages of intercropping as compared to mono-cropping are an important factor in making cropping decisions. As expected, availability of irrigation water has a positive effect on the use of intercropping. One additional round of irrigation is related to a $0.41 \mathrm{mu}$ increase in intercropping area on average. This result is consistent with the high water use in relay intercropping as compared to sole crops.

An important and unexpected finding is that possession of machinery has a significant positive impact on the use of intercropping. We will discuss this finding in more detail when we discuss the results for the individual intercropping systems. 
As regards human assets, we do not find a significant impact of any of the three indicators (education, age and labor-land ratio) on the adoption of intercropping. For knowledge and experience, as proxied by education and age, this finding is in line with those of Min et al. (2017) for southwest China and Ketema and Bauer (2012) for eastern Ethiopia and contrasts with the negative effect of age on the adoption of legume intercropping in Tanzania found by Kassie et al. (2013). Surprisingly, the labor-land ratio does not have a significant effect on the intercropping area. The fact that intercrops usually require more labor input than monocrops therefore does not seem to play an important role in crop choice decisions in the research area. The only financial asset in our model, household debt, is also found to have no significant impact on intercropping.

Demographic characteristics of households and their risk preferences also do not have significant effects on the use of intercropping for the households in the sample. For risk preferences, this result implies that the risk reduction aspects of intercropping may not be as important in household cropping decisions as much of the previous literature suggests (see Section 4.2.2). The regression results for number of plots and debt provide additional support for this conclusion, as we do not find evidence that farmers with few plots or with high debts use prefer the relatively stable yields of intercropping. In their research on the North China Plain, Feike et al. $(2010 ; 2012)$ also concluded that farmers do not consider lower cropping risks as a reason for intercropping. They explain this finding from the reliable supply of farm inputs, like irrigation water, fertilizer and pesticides, which ensure high crop yields.

The last column in Table 4.2 presents the regression results when rented-in land area is dropped from the equation. The adjusted R-square drops from 0.58 to 0.51 , indicating a noticeably lower goodness of fit. The main conclusions with respect to natural, physical, financial and human assets remain unchanged. But some of the estimated coefficients, particularly those for contracted land and number of plots, change considerably in magnitude. 
These results show the importance of including land rentals as a control variable in the model, even though it may be endogenous.

Different types of intercropping may differ in demands for labor and options for use of machinery, water use, crop failure risks, and so on. For example, seed watermelon/maize has relatively high labor demand while cumin/maize has relatively low water demand but higher risk of crop failure. We therefore estimated separate regressions for each of the three main intercrops. The results, with and without rented-in land area as a control variable, are presented in Table 4.3 .

Table 4.3 Regression results for area planted with three main intercrops (OLS)

\begin{tabular}{|c|c|c|c|c|c|c|}
\hline \multirow{3}{*}{$\begin{array}{l}\text { Explanatory } \\
\text { variables }\end{array}$} & \multicolumn{6}{|c|}{ Dependent variable } \\
\hline & \multicolumn{2}{|c|}{$\begin{array}{l}\text { Area of wheat/maize } \\
\text { intercropping }\end{array}$} & \multicolumn{2}{|c|}{$\begin{array}{l}\text { Area of cumin/maize } \\
\text { intercropping }\end{array}$} & \multicolumn{2}{|c|}{$\begin{array}{l}\text { Area of seed watermelon/ } \\
\text { maize intercropping }\end{array}$} \\
\hline & $\begin{array}{l}\text { With } \\
\text { land } \\
\text { rental }\end{array}$ & $\begin{array}{l}\text { Without } \\
\text { land rental }\end{array}$ & $\begin{array}{l}\text { With land } \\
\text { rental }\end{array}$ & $\begin{array}{l}\text { Without } \\
\text { land rental }\end{array}$ & $\begin{array}{l}\text { With land } \\
\text { rental }\end{array}$ & $\begin{array}{l}\text { Without land } \\
\text { rental }\end{array}$ \\
\hline \multicolumn{7}{|l|}{ Natural assets } \\
\hline Contracted land & $\begin{array}{r}0.040 \\
(0.044)\end{array}$ & $\begin{array}{r}0.027 \\
(0.035)\end{array}$ & $\begin{array}{c}0.318^{* * *} \\
(0.046)\end{array}$ & $\begin{array}{r}0.160^{* * *} \\
(0.038)\end{array}$ & $\begin{array}{r}0.072^{* * *} \\
(0.027)\end{array}$ & $\begin{array}{r}0.029 \\
(0.022)\end{array}$ \\
\hline Number of plots & $\begin{array}{r}0.050 \\
(0.047)\end{array}$ & $\begin{array}{r}0.062 \\
(0.039)\end{array}$ & $\begin{array}{r}0.073 \\
(0.049)\end{array}$ & $\begin{array}{r}0.226 \\
(0.043)\end{array}$ & $\begin{array}{r}0.005 \\
(0.029)\end{array}$ & $\begin{array}{l}0.046^{*} \\
(0.025)\end{array}$ \\
\hline Irrigation & $\begin{array}{c}0.363^{* * *} \\
(0.078)\end{array}$ & $\begin{array}{c}0.360^{* * *} \\
(0.078)\end{array}$ & $\begin{array}{r}-0.061 \\
(0.082)\end{array}$ & $\begin{array}{r}-0.094 \\
(0.086)\end{array}$ & $\begin{array}{l}0.108^{* *} \\
(0.049)\end{array}$ & $\begin{array}{r}0.099^{*} \\
(0.050)\end{array}$ \\
\hline \multicolumn{7}{|l|}{ Physical assets } \\
\hline Machinery & $\begin{array}{r}-0.424 \\
(0.359)\end{array}$ & $\begin{array}{r}-0.395 \\
(0.353)\end{array}$ & $\begin{array}{c}1.227^{* * *} \\
(0.374)\end{array}$ & $\begin{array}{l}1.578^{* * *} \\
(0.388)\end{array}$ & $\begin{array}{r}0.157 \\
(0.225)\end{array}$ & $\begin{array}{r}0.252 \\
(0.224)\end{array}$ \\
\hline \multicolumn{7}{|l|}{ Financial assets } \\
\hline Household Debt & $\begin{array}{r}0.035 \\
(0.027)\end{array}$ & $\begin{array}{r}0.035 \\
(0.027)\end{array}$ & $\begin{array}{r}-0.022 \\
(0.028)\end{array}$ & $\begin{array}{r}-0.026 \\
(0.030)\end{array}$ & $\begin{array}{r}-0.015 \\
(0.017)\end{array}$ & $\begin{array}{r}-0.016 \\
(0.017)\end{array}$ \\
\hline \multicolumn{7}{|l|}{ Human assets } \\
\hline Labor-land ratio & $\begin{array}{l}-1.167 \\
(0.912)\end{array}$ & $\begin{array}{r}-1.200 \\
(0.908)\end{array}$ & $\begin{array}{r}0.514 \\
(0.950)\end{array}$ & $\begin{array}{r}0.099 \\
(0.998)\end{array}$ & $\begin{array}{r}-0.422 \\
(0.572)\end{array}$ & $\begin{array}{r}-0.535 \\
(0.575)\end{array}$ \\
\hline Education & $\begin{array}{l}-0.531^{*} \\
(0.270)\end{array}$ & $\begin{array}{l}-0.518^{*} \\
(0.269)\end{array}$ & $\begin{array}{r}0.195 \\
(0.282)\end{array}$ & $\begin{array}{r}0.343 \\
(0.295)\end{array}$ & $\begin{array}{r}0.235 \\
(0.169)\end{array}$ & $\begin{array}{r}0.275 \\
(0.170)\end{array}$ \\
\hline Age & $\begin{array}{r}-0.320 \\
(0.204)\end{array}$ & $\begin{array}{r}-0.319 \\
(0.204)\end{array}$ & $\begin{array}{r}0.344 \\
(0.213)\end{array}$ & $\begin{array}{r}0.351 \\
(0.224)\end{array}$ & $\begin{array}{r}-0.163 \\
(0.128)\end{array}$ & $\begin{array}{r}-0.161 \\
(0.129)\end{array}$ \\
\hline $\begin{array}{l}\text { Household } \\
\text { characteristics }\end{array}$ & & & & & & \\
\hline Gender & $\begin{array}{r}1.633 \\
(1.151)\end{array}$ & $\begin{array}{r}1.56 / \\
(1.141)\end{array}$ & $\begin{array}{r}-3.375 \\
(1.199)\end{array}$ & $\begin{array}{r}-4.183 \\
(1.254)\end{array}$ & $\begin{array}{r}0.511 \\
(0.721)\end{array}$ & $\begin{array}{r}0.291 \\
(0.723)\end{array}$ \\
\hline Dependency ratio & $\begin{array}{r}0.769 \\
(0.691)\end{array}$ & $\begin{array}{r}0.755 \\
(0.689)\end{array}$ & $\begin{array}{c}-1.792^{* *} \\
(0.720)\end{array}$ & $\begin{array}{r}-1.959^{* * *} \\
(0.758)\end{array}$ & $\begin{array}{r}0.145 \\
(0.433)\end{array}$ & $\begin{array}{r}0.099 \\
(0.437)\end{array}$ \\
\hline
\end{tabular}




\begin{tabular}{|c|c|c|c|c|c|c|}
\hline Risk aversion & $\begin{array}{r}0.108 \\
(0.096)\end{array}$ & $\begin{array}{r}0.104 \\
(0.096)\end{array}$ & $\begin{array}{r}-0.135 \\
(0.100)\end{array}$ & $\begin{array}{r}-0.180 \\
(0.105)\end{array}$ & $\begin{array}{r}0.004 \\
(0.060)\end{array}$ & $\begin{array}{r}-0.008 \\
(0.061)\end{array}$ \\
\hline \multicolumn{7}{|l|}{ Village dummies } \\
\hline Huaqiangzi & $\begin{array}{r}0.264 \\
(0.338)\end{array}$ & $\begin{array}{r}0.248 \\
(0.336)\end{array}$ & $\begin{array}{r}-0.824^{* *} \\
(0.352)\end{array}$ & $\begin{array}{r}-1.021^{* * * *} \\
(0.370)\end{array}$ & $\begin{array}{r}0.025 \\
(0.212)\end{array}$ & $\begin{array}{r}-0.029 \\
(0.213)\end{array}$ \\
\hline Hexi & $\begin{array}{c}1.112^{* * * *} \\
(0.354)\end{array}$ & $\begin{array}{c}1.115^{* * *} \\
(0.354)\end{array}$ & $\begin{array}{r}-0.539 \\
(0.369)\end{array}$ & $\begin{array}{r}-0.496 \\
(0.389)\end{array}$ & $\begin{array}{c}0.576^{* * * *} \\
(0.222)\end{array}$ & $\begin{array}{r}0.587^{* * * *} \\
(0.224)\end{array}$ \\
\hline Net rented-in land & $\begin{array}{r}0.026 \\
(0.053)\end{array}$ & - & $\begin{array}{c}0.316^{* * * *} \\
(0.056)\end{array}$ & - & $\begin{array}{l}0.086^{* *} \\
(0.033)\end{array}$ & - \\
\hline Constant & $\begin{array}{r}1.178 \\
(1.694)\end{array}$ & $\begin{array}{r}1.240 \\
(1.687)\end{array}$ & $\begin{array}{r}-0.608 \\
(1.765)\end{array}$ & $\begin{array}{r}0.159 \\
(1.853)\end{array}$ & $\begin{array}{r}-0.594 \\
(1.062)\end{array}$ & $\begin{array}{r}-0.386 \\
(1.069)\end{array}$ \\
\hline $\begin{array}{l}\text { No. of } \\
\text { observations }\end{array}$ & 299 & 299 & 299 & 299 & 299 & 299 \\
\hline $\mathrm{R}^{2}$ & 0.184 & 0.184 & 0.474 & 0.414 & 0.209 & 0.190 \\
\hline Adjusted $\mathrm{R}^{2}$ & 0.144 & 0.146 & 0.448 & 0.387 & 0.170 & 0.153 \\
\hline
\end{tabular}

${ }^{*}{ }^{* *}$ and ${ }^{* * *}$ indicate statistical significance at $10 \%, 5 \%$ and $1 \%$ levels, respectively. Standard errors are reported in parentheses.

Contracted land has a significant positive effect on the areas planted with cumin/maize and seed watermelon/maize, but not on the wheat/maize intercropping area. On average, a one mu increase in contracted land area contributes to a $0.32 \mathrm{mu}$ increase in the area planted with cumin/maize, a $0.07 \mathrm{mu}$ increase in the area planted with seed watermelon/maize, but no significant increase in the area planted with the wheat/maize intercrop. Hence, larger farmers tend to prefer new intercropping types over the traditional wheat/maize intercrop. The estimated coefficients for the land rental variable show similar magnitudes. Regression results for the share of land under each main intercrop (Table A4.1 in the Appendix) show that larger farmers decrease the land shares under the traditional wheat/maize intercrop, but have similar land shares for the two new intercropping types as small farmers have.

None of the three main intercrops areas is significantly affected by the number of contracted plots on a farm. As a significant positive effect was found on the total intercropped area, this result suggests that land fragmentation plays a role especially in the adoption of relatively minor intercropping types. Availability of irrigation water has a significant positive effect on 
wheat/maize and seed watermelon/maize intercrops. It does not affect adoption of the intercrop with the lowest water demand, cumin/maize.

Use of machinery has a significant positive impact on the area planted with cumin/maize, but not on the other two main intercrops. Farmers in the research area use sowing machines that can be used for wheat as well as cumin in the wheat/maize and cumin maize intercrops. Seed watermelon, on the other hand, is planted manually in the seed watermelon/maize system. The regression results indicate that the availability of such sowing machines positively affects the adoption of the new intercrop for which it can be used, cumin/maize, but not of that of the traditional intercrop, wheat/maize.

Results for the financial and human assets variables are similar to those for total intercropping area, except for education in the wheat/maize intercropping equation. The significantly negative coefficient for education shows that households with more education are less likely to grow the wheat/maize intercrop that was been grown in the research area for nearly 40 years. Results for household characteristics, including the insignificant impact of risk aversion, for the three main intercrop types are also consistent with those for total intercropping area. The only exception is the significant negative impact of gender ratio and dependency ratio on the area under cumin/maize intercropping. The latter finding suggests that females with few dependants in the household play an important role in growing cumin/maize. More field research is needed to check this conclusion. The labor-land ratio does not significantly affect any of the three main intercrops. This also holds for seed watermelon/maize, which requires much more labour than the other two intercrops.

The significant positive coefficients for the Hexi village dummy in the wheat/maize and seed watermelon/maize equations indicate that farmers in this village are more likely to adopt these two systems as compared to farmers with similar asset levels and household characteristics in 
the other villages. Differences in agro-climatic factors and market conditions may explain this. Likewise, farmers in Huaqianzi village grow plant significantly less cumin/maize as compared to farmers with similar resources and characteristics in the other two villages.

To check the robustness of our results, we estimated the same regression equations with a Tobit model. The results can be found in Table A4.2 in the Appendix. The main results are very similar, with a few exceptions. Number of plots has a significant positive impact on cumin/maize intercropping area, suggesting that the positive impact of land fragmentation on intercropping (see Table 4.2) is found in particular for this specific intercrop. And age and gender instead of education are found to affect the area used for wheat/maize intercropping, suggesting that older farmers and households with a larger share of female laborers are less likely to adopt this intercrop. But the main conclusions with respect to the impact of contracted land area, irrigation water availability, use of mechanisation, labor-land ratio, and risk aversion remain unchanged. 


\subsection{Conclusion}

Intercropping can potentially reduce pressure on land resources by generating higher crop yields through exploitation of complementarities between species, reducing soil degradation and improving soil fertility. Although intercropping is practiced on a non-negligible part of China's arable land, little is known about the socio-economic factors that influence farmers' decisions to use intercropping systems. In this study we examine the impact of farm household assets and household characteristics like risk aversion on the adoption of traditional as well as new types of intercropping for a region in northwest China where intercropping is relatively popular. We find that natural assets (land and irrigation water) are important determinants of the use of intercropping, while human assets (including labor-land ratios) and financial assets do not have a significant effect. Neither do risk aversion perceptions of farm households play a significant role. Availability of machinery has no negative effect on the area under intercropping, and has a significant positive effect on the adoption of one novel intercrop type (cumin/maize). These findings provide important insights into some (often unintended) effects on natural resource use of recent agricultural policies and other major ongoing trends.

Farm scale enlargement has received much attention in agricultural policy making in China in recent years. Increasing farm sizes up to levels where rural households can make a living by working (almost) full-time on their own farms is considered an important path towards agricultural modernization. In the case study presented in this study, we found that larger farms have smaller land shares under the wheat/maize intercrop that is traditionally grown in the region as compared to small farms. But the land shares grown with two relatively new intercropping types do not significantly differ between large and small farms. Hence, farm scale enlargement in this region is expected to reduce the area grown with the traditional 
intercrop but will probably not have much impact on the land shares grown under the relatively new intercrops.

Measures taken to deal with rapidly growing water scarcity in northern China may become another important factor in the adoption of intercrops and in realising the natural resource use benefits of such systems. Our regression results show that both the traditional wheat/maize intercrop and the novel seed watermelon/maize intercrop become less popular when availability of irrigation declines. Only intercrops requiring relatively little water, like cumin/maize in the research area, are likely to remain unaffected. In the case of cumin/maize, it also happens to be an intercrop that can be planted with available machinery. Although labor availability does not play a significant role in the intercropping adoption decsions of farmers in our sample, the availability of such machinery does. Policies that aim at improving natural resource use efficiencies in agricultural production should therefore consider promoting in particular intercropping systems that have similar low water needs and favorable mechanization potentials as the cumin/maize intercrop in our study.

\section{Acknowledgements}

We gratefully acknowledge helpful discussions with Prof. Fusuo Zhang, Dr. Chaochun Zhang and Dr. Yajun Wang. The financial support from the China Scholarship Council (CSC, grant number: 201206300117) and the Key Sino-Dutch Joint Research Project of NSFC (Grant number: 31210103906) are gratefully acknowledged. 


\section{References}

Bekele, W., \& Drake, L. (2003). Soil and Water Conservation Decision Behavior of Subsistence Farmers in the Eastern Highlands of Ethiopia: A Case Study of the Hunde-Lafto Area. Ecological Economics, 46(3), 437-451.

Charlesworth, N. (1983). The Origins of Fragmentation of Land Holdings in British India: A Comparative Examination. In P. Robb (Ed.), Rural India: Land, Power and Society under British Rule. London: Carson Press.

Che, J., Wu, J., \& Song, H. (2011). A Review on the Researches on Sugarcane-Soybean Intercropping System. Journal of Southern Agriculture, 42(8), 898-900 (in Chinese).

Clawson, D.L. (1985). Harvest Security and Intraspecific Diversity in Traditional Tropical Agriculture. Economic Botany, 39(1), 56-67.

Dakora, F. (1997). Using Indigenous Knowledge to Increase Agricultural Productivity in Africa. In N. Hans, S. Ina, \& C. Morris (Eds.), Indigenous Knowledge and Its Uses in Southern Africa. Pretoria, South Africa: The Human Sciences Research Council.

Ellis, F. (2000). Rural Livelihoods and Diversity in Developing Countries. Oxford, UK: Oxford university press.

Feder, G., Just, R.E., \& Zilberman, D. (1985). Adoption of Agricultural Innovations in Developing Countries: A Survey. Economic Development and Cultural Change, 33(2), 255-298.

Feike, T., Chen, Q., Graeff-Hönninger, S., Pfenning, J., \& Claupein, W. (2010). FarmerDeveloped Vegetable Intercropping Systems in Southern Hebei, China. Renewable Agriculture and Food Systems, 25(04), 272-280.

Feike, T., Chen, Q., Gräff-Hönninger, S., \& Claupein, W. (2009). Influence of Policy Measures and Economic Growth on Intercropping Systems in China. Paper presented the International Research on Food Security, Natural Resource Management and Rural Development, Hamburg.

Feike, T., Doluschitz, R., Chen, Q., Graeff-Hönninger, S., \& Claupein, W. (2012). How to Overcome the Slow Death of Intercropping in the North China Plain. Sustainability, 4(10), 2550-2565.

Foster, G., \& Kalenkoski, C.M. (2013). Tobit or Ols? An Empirical Evaluation under Different Diary Window Lengths. Applied Economics, 45(20), 2994-3010. 
Francis, C.A. (1986). Multiple Cropping Systems. New York: Macmillan Publishing Company. Gou, F., Yin, W., Hong, Y., van der Werf, W., Chai, Q., Heerink, N., et al. (2017). On Yield Gaps and Yield Gains in Intercropping: Opportunities for Increasing Grain Production in Northwest China. Agricultural Systems, 151, 96-105.

Greene, W.H. (2003). Econometric Analysis (fifth ed.). New Jersey: Prentice Hall. Han, G., Jie, L., Yan, S., Wang, Y., Zhu, Y., \& Lu, B. (2016). Intercropping of Rice Varieties Increases the Efficiency of Blast Control through Reduced Disease Occurrence and Variability. Journal of Integrative Agriculture, 15(4), 795-802.

Himmelstein, J., Ares, A., Gallagher, D., \& Myers, J. (2017). A Meta-Analysis of Intercropping in Africa: Impacts on Crop Yield, Farmer Income, and Integrated Pest Management Effects. International Journal of Agricultural Sustainability, 15(1), 1-10.

Hong, Y., Heerink, N., Jin, S., Berentsen, P., Zhang, L., \& van der Werf, W. (2017). Intercropping and Agricultural in China-Current State and Trends. Agriculture Ecosystems \& Environment, 244, 52-61.

Horwith, B. (1985). A Role for Intercropping in Modern Agriculture. Bioscience, 35(5), 286291.

Huang, C., Liu, Q., Heerink, N., Stomph, T., Li, B., Liu, R., et al. (2015). Economic Performance and Sustainability of a Novel Intercropping System on the North China Plain. PloS One, 10(8), e0135518.

Ilbery, B.W. (1984). Farm Fragmentation in the Vale of Evesham. Area, 6(2), 159-165.

Jodha, N. (1980). Intercropping in Traditional Farming Systems. The Journal of Development Studies, 16(4), 427-442.

Kassie, M., Jaleta, M., Shiferaw, B., Mmbando, F., \& Mekuria, M. (2013). Adoption of Interrelated Sustainable Agricultural Practices in Smallholder Systems: Evidence from Rural Tanzania. Technological Forecasting and Social Change, 80(3), 525-540.

Kebede, Y., Gunjal, K., \& Coffin, G. (1990). Adoption of New Technologies in Ethiopian Agriculture: The Case of Tegulet-Bulga District Shoa Province. Agricultural Economics, 4(1), 27-43.

Ketema, M., \& Bauer, S. (2012). Factors Affecting Intercropping and Conservation Tillage Practices in Eeastern Ethiopia. AGRIS on-line Papers in Economics and Informatics, 4(1), 21. 
Knörzer, H., Graeff-Hönninger, S., Guo, B., Wang, P., \& Claupein, W. (2009). The Rediscovery of Intercropping in China: A Traditional Cropping System for Future Chinese Agriculture - a Review. In E. Lichtfouse (Ed.), Climate Change, Intercropping, Pest Control and Beneficial, Microorganisms (pp. 13-44). Dordrecht: Springer Netherlands.

Li, L., Sun, J., Zhang, F., Li, X., Yang, S., \& Rengel, Z. (2001). Wheat/Maize or Wheat/Soybean Strip Intercropping: I. Yield Advantage and Interspecific Interactions on Nutrients. Field Crops Research, 71(2), 123-137.

Li, L., Yang, S., Li, X., Zhang, F., \& Christie, P. (1999). Interspecific Complementary and Competitive Interactions between Intercropped Maize and Faba Bean. Plant and Soil, 212(2), 105-114.

Li, W., Li, L., Sun, J., Guo, T., Zhang, F., Bao, X., et al. (2005). Effects of Intercropping and Nitrogen Application on Nitrate Present in the Profile of an Orthic Anthrosol in Northwest China. Agriculture, Ecosystems \& Environment, 105(3), 483-491.

Li, X., Mu, Y., Cheng, Y., Liu, X., \& Nian, H. (2013). Effects of Intercropping Sugarcane and Soybean on Growth, Rhizosphere Soil Microbes, Nitrogen and Phosphorus Availability. Acta physiologiae plantarum, 35(4), 1113-1119.

Lithourgidis, A., Dordas, C., Damalas, C., \& Vlachostergios, D. (2011). Annual Intercrops: An Alternative Pathway for Sustainable Agriculture. Australian journal of crop science, 5(4), 396.

Luo, F., Qi, S., \& Xiao, H. (2005). Landscape Change and Sandy Desertification in Arid Areas: A Case Study in the Zhangye Region of Gansu Province, China. Environmental Geology, 49(1), 90-97.

Ma, X., Heerink, N., Feng, S., \& Shi, X. (2015). Farmland Tenure in China: Comparing Legal, Actual and Perceived Security. Land Use Policy, 42, 293-306.

Machado, S. (2009). Does Intercropping Have a Role in Modern Agriculture? Journal of Soil and Water Conservation, 64(2), 55A-57A.

Mao, L., Zhang, L., Li, W., van der Werf, W., Sun, J., Spiertz, H., et al. (2012). Yield Advantage and Water Saving in Maize/Pea Intercrop. Field Crops Research, 138, 11-20.

Mao, L., Zhang, L., Zhang, S., Evers, J.B., van der Werf, W., Wang, J., et al. (2015). Resource Use Efficiency, Ecological Intensification and Sustainability of Intercropping Systems. Journal of Integrative Agriculture, 14(8), 1542-1550. 
Mead, R., \& Willey, R. (1980). The Concept of a 'Land Equivalent Ratio'and Advantages in Yields from Intercropping. Experimental Agriculture, 16(3), 217-228.

Min, S., Huang, J., Bai, J., \& Waibel, H. (2017). Adoption of Intercropping among Smallholder Rubber Farmers in Xishuangbanna, China. International Journal of Agricultural Sustainability, 15(3), 223-237.

Mkamilo, G.S. (2004). Maize-Sesame Intercropping in Southeast Tanzania: Farmers' Practices and Perceptions, and Intercrop Perfromance. (Doctor Thesis), Wageingen University, The Netherlands.

Ngwira, A., Johnsen, F.H., Aune, J.B., Mekuria, M., \& Thierfelder, C. (2014). Adoption and Extent of Conservation Agriculture Practices among Smallholder Farmers in Malawi. Journal of Soil and Water Conservation, 69(2), 107-119.

Nkonya, E., Schroeder, T., \& Norman, D. (1997). Factors Affecting Adoption of Improved Maize Seed and Fertiliser in Northern Tanzania. Journal of Agricultural Economics, $48(1-3), 1-12$.

Ouma, J., \& De Groote, H. (2011). Determinants of Improved Maize Seed and Fertilizer Adoption in Kenya. Journal of Development and Agricultural Economics, 3(11), 529536.

Revilla-Molina, I.M., Bastiaans, L., Van Keulen, H., Kropff, M., Hui, F., Castilla, N., et al. (2009). Does Resource Complementarity or Prevention of Lodging Contribute to the Increased Productivity of Rice Varietal Mixtures in Yunnan, China? Field Crops Research, 111(3), 303-307.

Scoones, I. (2015). Sustainable Livelihoods and Rural Development. UK: Practical Action Publishing Rugby.

Shi, M., Wang, X., Yang, H., \& Wang, T. (2014). Pricing or Quota? A Solution to Water Scarcity in Oasis Regions in China: A Case Study in the Heihe River Basin. Sustainability, 6(11), 7601-7620.

Tobin, J. (1958). Estimation of Relationships for Limited Dependent Variables. Econometrica: Journal of the Econometric Society, 24-36.

Vandermeer, J.H. (1989). The Ecology of Intercropping. Cambridge: Cambridge University Press. 
Wang, Z., Bao, X., Li, X., Jin, X., Zhao, J., Sun, J., et al. (2015). Intercropping Maintains Soil Fertility in Terms of Chemical Properties and Enzyme Activities on a Timescale of One Decade. Plant and Soil, 391(1-2), 265-282.

Wang, Z., Zhao, X., Wu, P., He, J., Chen, X., Gao, Y., et al. (2015). Radiation Interception and Utilization by Wheat/Maize Strip Intercropping Systems. Agricultural and Forest Meteorology, 204, 58-66. doi: 10.1016/j.agrformet.2015.02.004

Willey, R. (1979a). Intercropping-Its Importance and Research Needs. Part 1. Competition and Yield Advantages. Field Crop Abstracts, 32.

Yan, Y., Gong, W., Yang, W., Wan, Y., Chen, X., Chen, Z., et al. (2010). Seed Treatment with Uniconazole Powder Improves Soybean Seedling Growth under Shading by Corn in Relay Strip Intercropping System. Plant Production Science, 13(4), 367-374.

Yang, R., \& Liu, W. (2010). Nitrate Contamination of Groundwater in an Agroecosystem in Zhangye Oasis, Northwest China. Environmental Earth Sciences, 61(1), 123-129.

Yin, W., Yu, A., Chai, Q., Hu, F., Feng, F., \& Gan, Y. (2015). Wheat and Maize Relay-Planting with Straw Covering Increases Water Use Efficiency up to 46\%. Agronomy for Sustainable Development, 35(2), 815-825.

Yu, Y., Makowski, D., Stomph, T.-J., \& Van Der Werf, W. (2016). Robust Increases of Land Equivalent Ratio with Temporal Niche Differentiation: A Meta-Quantile Regression. Agronomy Journal, 108(6), 2269-2279.

Yu, Y., Stomph, T.-J., Makowski, D., \& van der Werf, W. (2015). Temporal Niche Differentiation Increases the Land Equivalent Ratio of Annual Intercrops: A MetaAnalysis. Field Crops Research, 184, 133-144.

Zhang, F., \& Li, L. (2003). Using Competitive and Facilitative Interactions in Intercropping Systems Enhances Crop Productivity and Nutrient-Use Efficiency. Plant and Soil, 248(1-2), 305-312.

Zhang, J. (2007). Barriers to Water Markets in the Heihe River Basin in Northwest China. Agricultural Water Management, 87(1), 32-40.

Zhang, L., Heerink, N., Dries, L., \& Shi, X. (2013). Water Users Associations and Irrigation Water Productivity in Northern China. Ecological Economics, 95, 128-136.

Zhu, Y., Chen, H., Fan, J., Wang, Y., Li, Y., Chen, J., et al. (2000). Genetic Diversity and Disease Control in Rice. Nature, 406(6797), 718-722. 


\section{Appendix}

Table A4.1 Regression results for shares of land under intercropping (OLS)

\begin{tabular}{|c|c|c|c|c|c|c|c|c|}
\hline \multirow{3}{*}{$\begin{array}{l}\text { Explanatory } \\
\text { variables } \\
\end{array}$} & \multicolumn{8}{|c|}{ Dependent variable } \\
\hline & \multicolumn{2}{|c|}{$\begin{array}{l}\text { Share of total } \\
\text { intercropping }\end{array}$} & \multicolumn{2}{|c|}{$\begin{array}{l}\text { share of wheat/maize } \\
\text { intercropping }\end{array}$} & \multicolumn{2}{|c|}{$\begin{array}{l}\text { share of cumin/maize } \\
\text { intercropping }\end{array}$} & \multicolumn{2}{|c|}{$\begin{array}{l}\text { share of seed } \\
\text { watermelon/ } \\
\text { maize intercropping }\end{array}$} \\
\hline & $\begin{array}{l}\text { With } \\
\text { land } \\
\text { rental }\end{array}$ & $\begin{array}{l}\text { Without } \\
\text { land } \\
\text { rental }\end{array}$ & $\begin{array}{l}\text { With } \\
\text { land } \\
\text { rental }\end{array}$ & $\begin{array}{l}\text { Without } \\
\text { land } \\
\text { rental }\end{array}$ & $\begin{array}{l}\text { With } \\
\text { land } \\
\text { rental }\end{array}$ & $\begin{array}{l}\text { Without } \\
\text { land } \\
\text { rental }\end{array}$ & $\begin{array}{l}\text { With } \\
\text { land } \\
\text { rental }\end{array}$ & $\begin{array}{l}\text { Without } \\
\text { land } \\
\text { rental }\end{array}$ \\
\hline \multicolumn{9}{|l|}{ Natural assets } \\
\hline Contracted land & $\begin{array}{r}-0.015^{* * *} \\
(0.005)\end{array}$ & $\begin{array}{r}-0.006 \\
(0.004)\end{array}$ & $\begin{array}{r}-0.011^{* *} \\
(0.005)\end{array}$ & $\begin{array}{l}-0.006^{*} \\
(0.004)\end{array}$ & $\begin{array}{r}-0.000 \\
(0.004)\end{array}$ & $\begin{array}{r}0.002 \\
(0.003)\end{array}$ & $\begin{array}{r}-0.003 \\
(0.003)\end{array}$ & $\begin{array}{l}-0.002 \\
(0.002)\end{array}$ \\
\hline Number of plots & $\begin{array}{l}0.011^{* *} \\
(0.005)\end{array}$ & $\begin{array}{r}0.003 \\
(0.004)\end{array}$ & $\begin{array}{r}0.003 \\
(0.005)\end{array}$ & $\begin{array}{r}-0.002 \\
(0.004)\end{array}$ & $\begin{array}{r}0.008^{*} \\
(0.004)\end{array}$ & $\begin{array}{r}0.007^{*} \\
(0.004)\end{array}$ & $\begin{array}{r}-0.000 \\
(0.003)\end{array}$ & $\begin{array}{l}-0.001 \\
(0.003)\end{array}$ \\
\hline Irrigation & $\begin{array}{c}0.056^{* * *} \\
(0.009)\end{array}$ & $\begin{array}{c}0.057^{* * *} \\
(0.009)\end{array}$ & $\begin{array}{c}0.050^{* * *} \\
(0.008)\end{array}$ & $\begin{array}{c}0.051^{* * *} \\
(0.008)\end{array}$ & $\begin{array}{r}-0.008 \\
(0.007)\end{array}$ & $\begin{array}{r}-0.007 \\
(0.007)\end{array}$ & $\begin{array}{l}0.013^{* * *} \\
(0.005)\end{array}$ & $\begin{array}{r}0.014^{* * *} \\
(0.005)\end{array}$ \\
\hline \multicolumn{9}{|l|}{ Physical assets } \\
\hline Machinery & $\begin{array}{l}0.096^{* *} \\
(0.042)\end{array}$ & $\begin{array}{c}0.078^{*} \\
(0.042)\end{array}$ & $\begin{array}{r}-0.061 \\
(0.038)\end{array}$ & $\begin{array}{l}-0.073^{*} \\
(0.037)\end{array}$ & $\begin{array}{r}0.145^{* * *} \\
(0.034)\end{array}$ & $\begin{array}{c}0.141^{* * *} \\
(0.033)\end{array}$ & $\begin{array}{r}0.012 \\
(0.023)\end{array}$ & $\begin{array}{r}0.010 \\
(0.023)\end{array}$ \\
\hline \multicolumn{9}{|l|}{ Financial assets } \\
\hline Household debt & $\begin{array}{r}-0.001 \\
(0.003)\end{array}$ & $\begin{array}{r}-0.001 \\
(0.003)\end{array}$ & $\begin{array}{r}0.003 \\
(0.003)\end{array}$ & $\begin{array}{r}0.004 \\
(0.003)\end{array}$ & $\begin{array}{r}-0.002 \\
(0.003)\end{array}$ & $\begin{array}{r}-0.002 \\
(0.003)\end{array}$ & $\begin{array}{r}-0.003 \\
(0.002)\end{array}$ & $\begin{array}{r}-0.003 \\
(0.002)\end{array}$ \\
\hline \multicolumn{9}{|l|}{ Human assets } \\
\hline Labor-land ratio & $\begin{array}{r}-0.032 \\
(0.107)\end{array}$ & $\begin{array}{r}-0.011 \\
(0.107)\end{array}$ & $\begin{array}{r}0.137 \\
(0.096)\end{array}$ & $\begin{array}{r}0.151 \\
(0.096)\end{array}$ & $\begin{array}{l}-0.117 \\
(0.086)\end{array}$ & $\begin{array}{l}-0.111 \\
(0.086)\end{array}$ & $\begin{array}{r}-0.053 \\
(0.060)\end{array}$ & $\begin{array}{r}-0.050 \\
(0.060)\end{array}$ \\
\hline Education & $\begin{array}{r}0.010 \\
(0.032)\end{array}$ & $\begin{array}{r}0.003 \\
(0.032)\end{array}$ & $\begin{array}{r}-0.033 \\
(0.028)\end{array}$ & $\begin{array}{r}-0.038 \\
(0.028)\end{array}$ & $\begin{array}{r}0.036 \\
(0.025)\end{array}$ & $\begin{array}{r}0.034 \\
(0.025)\end{array}$ & $\begin{array}{r}0.007 \\
(0.018)\end{array}$ & $\begin{array}{r}0.006 \\
(0.018)\end{array}$ \\
\hline Age & $\begin{array}{r}0.002 \\
(0.024)\end{array}$ & $\begin{array}{r}0.002 \\
(0.024)\end{array}$ & $\begin{array}{r}0.007 \\
(0.021)\end{array}$ & $\begin{array}{r}0.007 \\
(0.022)\end{array}$ & $\begin{array}{r}0.028 \\
(0.019)\end{array}$ & $\begin{array}{r}0.034 \\
(0.025)\end{array}$ & $\begin{array}{r}-0.033 * * \\
(0.013)\end{array}$ & $\begin{array}{c}-0.033^{* *} \\
(0.013)\end{array}$ \\
\hline \multicolumn{9}{|l|}{$\begin{array}{l}\text { Household } \\
\text { characteristics }\end{array}$} \\
\hline Gender & $\begin{array}{r}-0.103 \\
(0.134)\end{array}$ & $\begin{array}{r}-0.061 \\
(0.135)\end{array}$ & $\begin{array}{c}0.330^{* * * *} \\
(0.121)\end{array}$ & $\begin{array}{c}0.356^{* * *} \\
(0.120)\end{array}$ & $\begin{array}{r}-0.422^{\text {**** }} \\
(0.108)\end{array}$ & $\begin{array}{r}-0.412^{* * *} \\
(0.107)\end{array}$ & $\begin{array}{r}-0.011 \\
(0.075)\end{array}$ & $\begin{array}{l}-0.005 \\
(0.075)\end{array}$ \\
\hline $\begin{array}{l}\text { Dependency } \\
\text { ratio }\end{array}$ & $\begin{array}{r}-0.049 \\
(0.081)\end{array}$ & $\begin{array}{r}-0.040 \\
(0.081)\end{array}$ & $\begin{array}{l}0.161^{* *} \\
(0.073)\end{array}$ & $\begin{array}{c}0.166^{* * * *} \\
(0.073)\end{array}$ & $\begin{array}{r}-0.200^{* * * *} \\
(0.065)\end{array}$ & $\begin{array}{r}-0.198^{* * * *} \\
(0.065)\end{array}$ & $\begin{array}{r}-0.010 \\
(0.045)\end{array}$ & $\begin{array}{l}-0.008 \\
(0.045)\end{array}$ \\
\hline Risk aversion & $\begin{array}{r}-0.002 \\
(0.011)\end{array}$ & $\begin{array}{r}0.000 \\
(0.011)\end{array}$ & $\begin{array}{r}0.009 \\
(0.010)\end{array}$ & $\begin{array}{r}0.011 \\
(0.010)\end{array}$ & $\begin{array}{r}-0.006 \\
(0.009)\end{array}$ & $\begin{array}{r}-0.005 \\
(0.009)\end{array}$ & $\begin{array}{r}-0.006 \\
(0.006)\end{array}$ & $\begin{array}{r}-0.006 \\
(0.006)\end{array}$ \\
\hline \multicolumn{9}{|l|}{$\begin{array}{l}\text { Village } \\
\text { dummies }\end{array}$} \\
\hline Huaqiangzi & $\begin{array}{c}-0.099^{* *} \\
(0.040)\end{array}$ & $\begin{array}{c}-0.089^{* *} \\
(0.040)\end{array}$ & $\begin{array}{r}-0.010 \\
(0.036)\end{array}$ & $\begin{array}{r}-0.003 \\
(0.035)\end{array}$ & $\begin{array}{r}-0.084^{* * * *} \\
(0.032)\end{array}$ & $\begin{array}{r}-0.082^{* * *} \\
(0.032)\end{array}$ & $\begin{array}{r}-0.005 \\
(0.022)\end{array}$ & $\begin{array}{r}-0.004 \\
(0.022)\end{array}$ \\
\hline Hexi & $\begin{array}{c}0.070^{*} \\
(0.041)\end{array}$ & $\begin{array}{r}0.068 \\
(0.042)\end{array}$ & $\begin{array}{c}0.127^{* * *} \\
(0.037)\end{array}$ & $\begin{array}{r}0.126^{* * * *} \\
(0.037)\end{array}$ & $\begin{array}{r}-0.089^{* * * *} \\
(0.033)\end{array}$ & $\begin{array}{r}-0.089^{* * * *} \\
(0.033)\end{array}$ & $\begin{array}{r}0.032 \\
(0.023)\end{array}$ & $\begin{array}{r}0.031 \\
(0.023)\end{array}$ \\
\hline $\begin{array}{l}\text { Net rented-in } \\
\text { land }\end{array}$ & $\begin{array}{r}-0.017^{* * * *} \\
(0.006)\end{array}$ & - & $\begin{array}{l}-0.010^{*} \\
(0.006)\end{array}$ & - & $\begin{array}{r}-0.004 \\
(0.005)\end{array}$ & - & $\begin{array}{r}-0.002 \\
(0.003)\end{array}$ & - \\
\hline Constant & $\begin{array}{l}0.401^{* *} \\
(0.198)\end{array}$ & $\begin{array}{r}0.360^{*} \\
(0.199)\end{array}$ & $\begin{array}{r}-0.130 \\
(0.178)\end{array}$ & $\begin{array}{r}-0.156 \\
(0.178)\end{array}$ & $\begin{array}{r}0.306^{*} \\
(0.159)\end{array}$ & $\begin{array}{r}0.296^{*} \\
(0.159)\end{array}$ & $\begin{array}{l}0.225^{* *} \\
(0.111)\end{array}$ & $\begin{array}{l}0.220^{* *} \\
(0.111)\end{array}$ \\
\hline $\begin{array}{l}\text { No. of } \\
\text { observations }\end{array}$ & 299 & 299 & 299 & 299 & 299 & 299 & 299 & 299 \\
\hline $\mathrm{R}^{2}$ & 0.181 & 0.161 & 0.300 & 0.291 & 0.211 & 0.209 & 0.071 & 0.070 \\
\hline Adjusted R ${ }^{2}$ & 0.141 & 0.123 & 0.265 & 0.259 & 0.172 & 0.173 & 0.026 & 0.028 \\
\hline
\end{tabular}

${ }^{*},{ }^{* *}$ and ${ }^{* * *}$ indicate statistical significance at $10 \%, 5 \%$ and $1 \%$ levels, respectively. Standard errors are reported

in parentheses. 
Table A4.2 Regression results for area of land planted with intercrops (Tobit)

\begin{tabular}{|c|c|c|c|c|c|c|c|c|}
\hline \multirow{3}{*}{$\begin{array}{l}\text { Explanatory } \\
\text { variables }\end{array}$} & \multicolumn{8}{|c|}{ Dependent variable } \\
\hline & \multicolumn{2}{|c|}{$\begin{array}{l}\text { Area of total } \\
\text { intercropping }\end{array}$} & \multicolumn{2}{|c|}{$\begin{array}{l}\text { Area of } \\
\text { wheat/maize } \\
\text { intercropping }\end{array}$} & \multicolumn{2}{|c|}{$\begin{array}{l}\text { Area of cumin/maize } \\
\text { intercropping }\end{array}$} & \multicolumn{2}{|c|}{$\begin{array}{l}\text { Area of seed } \\
\text { watermelon/ } \\
\text { maize intercropping }\end{array}$} \\
\hline & $\begin{array}{l}\text { With } \\
\text { land } \\
\text { rental }\end{array}$ & $\begin{array}{l}\text { Without } \\
\text { land } \\
\text { rental }\end{array}$ & $\begin{array}{l}\text { With } \\
\text { land } \\
\text { rental }\end{array}$ & $\begin{array}{l}\text { Without } \\
\text { land } \\
\text { rental }\end{array}$ & $\begin{array}{l}\text { With } \\
\text { land } \\
\text { rental }\end{array}$ & $\begin{array}{l}\text { Without } \\
\text { land } \\
\text { rental }\end{array}$ & $\begin{array}{l}\text { With } \\
\text { land } \\
\text { rental }\end{array}$ & $\begin{array}{l}\text { Without } \\
\text { land } \\
\text { rental }\end{array}$ \\
\hline \multicolumn{9}{|l|}{ Natural assets } \\
\hline Contracted land & $\begin{array}{r}0.425^{* * *} \\
(0.054)\end{array}$ & $\begin{array}{r}0.213^{* * *} \\
(0.046)\end{array}$ & $\begin{array}{r}0.022 \\
(0.058)\end{array}$ & $\begin{array}{r}0.011 \\
(0.046)\end{array}$ & $\begin{array}{c}0.323^{* * *} \\
(0.067)\end{array}$ & $\begin{array}{r}0.153^{* * *} \\
(0.056)\end{array}$ & $\begin{array}{c}0.991^{*} \\
(0.057)\end{array}$ & $\begin{array}{r}0.037 \\
(0.046)\end{array}$ \\
\hline $\begin{array}{l}\text { Number of } \\
\text { plots }\end{array}$ & $\begin{array}{l}0.147^{* *} \\
(0.057)\end{array}$ & $\begin{array}{r}0.353^{* * *} \\
(0.051)\end{array}$ & $\begin{array}{r}0.081 \\
(0.061)\end{array}$ & $\begin{array}{l}0.091^{*} \\
(0.051)\end{array}$ & $\begin{array}{l}0.144^{* *} \\
(0.070)\end{array}$ & $\begin{array}{r}0.313^{* * *} \\
(0.062)\end{array}$ & $\begin{array}{r}0.025 \\
(0.061)\end{array}$ & $\begin{array}{r}0.089^{*} \\
(0.052)\end{array}$ \\
\hline Irrigation & $\begin{array}{c}0.459^{* * *} \\
(0.097)\end{array}$ & $\begin{array}{c}0.419^{* * *} \\
(0.104)\end{array}$ & $\begin{array}{r}0.517^{* * * *} \\
(0.105)\end{array}$ & $\begin{array}{c}0.514^{* * *} \\
(0.105)\end{array}$ & $\begin{array}{r}-0.194 \\
(0.127)\end{array}$ & $\begin{array}{l}-0.249^{*} \\
(0.134)\end{array}$ & $\begin{array}{l}0.261^{* *} \\
(0.113)\end{array}$ & $\begin{array}{l}0.244^{* *} \\
(0.114)\end{array}$ \\
\hline \multicolumn{9}{|l|}{ Physical assets } \\
\hline Machinery & $\begin{array}{c}1.145^{* * *} \\
(0.442)\end{array}$ & $\begin{array}{c}1.655^{* * *} \\
(0.470)\end{array}$ & $\begin{array}{r}-0.375 \\
(0.474)\end{array}$ & $\begin{array}{r}-0.349 \\
(0.466)\end{array}$ & $\begin{array}{c}2.252^{* * *} \\
(0.578)\end{array}$ & $\begin{array}{c}2.712^{* * * *} \\
(0.600)\end{array}$ & $\begin{array}{r}0.443 \\
(0.524)\end{array}$ & $\begin{array}{r}0.620 \\
(0.522)\end{array}$ \\
\hline \multicolumn{9}{|l|}{$\begin{array}{l}\text { Financial } \\
\text { assets }\end{array}$} \\
\hline Household debt & $\begin{array}{r}-0.002 \\
(0.033)\end{array}$ & $\begin{array}{r}-0.007 \\
(0.036)\end{array}$ & $\begin{array}{r}0.043 \\
(0.036)\end{array}$ & $\begin{array}{r}0.042 \\
(0.036)\end{array}$ & $\begin{array}{r}-0.033 \\
(0.041)\end{array}$ & $\begin{array}{r}-0.374 \\
(0.044)\end{array}$ & $\begin{array}{r}-0.033 \\
(0.036)\end{array}$ & $\begin{array}{l}-0.034 \\
(0.036)\end{array}$ \\
\hline \multicolumn{9}{|l|}{ Human assets } \\
\hline $\begin{array}{l}\text { Labor-land } \\
\text { ratio }\end{array}$ & $\begin{array}{r}-1.348 \\
(1.126)\end{array}$ & $\begin{array}{r}-1.934 \\
(1.211)\end{array}$ & $\begin{array}{r}-1.627 \\
(1.208)\end{array}$ & $\begin{array}{r}-1.653 \\
(1.206)\end{array}$ & $\begin{array}{r}-2.139 \\
(1.727)\end{array}$ & $\begin{array}{l}-2.942 \\
(1.836)\end{array}$ & $\begin{array}{r}-1.812 \\
(0.130)\end{array}$ & $\begin{array}{l}-1.985 \\
(1.430)\end{array}$ \\
\hline Education & $\begin{array}{r}-0.071 \\
(0.331)\end{array}$ & $\begin{array}{r}0.134 \\
(0.355)\end{array}$ & $\begin{array}{r}-0.547 \\
(0.360)\end{array}$ & $\begin{array}{r}-0.538 \\
(0.359)\end{array}$ & $\begin{array}{r}0.382 \\
(0.414)\end{array}$ & $\begin{array}{r}0.552 \\
(0.435)\end{array}$ & $\begin{array}{r}0.496 \\
(0.373)\end{array}$ & $\begin{array}{r}0.570 \\
(0.376)\end{array}$ \\
\hline Age & $\begin{array}{r}-0.151 \\
(0.250)\end{array}$ & $\begin{array}{r}-0.146 \\
(0.270)\end{array}$ & $\begin{array}{l}-0.453^{*} \\
(0.269)\end{array}$ & $\begin{array}{l}-0.453^{*} \\
(0.269)\end{array}$ & $\begin{array}{r}0.347 \\
(0.319)\end{array}$ & $\begin{array}{r}0.349 \\
(0.336)\end{array}$ & $\begin{array}{r}-0.471 \\
(0.285)\end{array}$ & $\begin{array}{r}-0.463 \\
(0.288)\end{array}$ \\
\hline \multicolumn{9}{|l|}{$\begin{array}{l}\text { Household } \\
\text { characteristics }\end{array}$} \\
\hline Gender & $\begin{array}{l}-1.199 \\
(1.406)\end{array}$ & $\begin{array}{l}-2.266 \\
(1.505)\end{array}$ & $\begin{array}{c}2.756^{*} \\
(1.513)\end{array}$ & $\begin{array}{l}2.694^{*} \\
(1.500)\end{array}$ & $\begin{array}{r}-6.687^{* * *} \\
(1.996)\end{array}$ & $\begin{array}{c}-7.784^{* * *} \\
(2.089)\end{array}$ & $\begin{array}{r}0.477 \\
(1.574)\end{array}$ & $\begin{array}{r}0.147 \\
(1.579)\end{array}$ \\
\hline $\begin{array}{l}\text { Dependency } \\
\text { ratio }\end{array}$ & $\begin{array}{r}-0.901 \\
(0.847)\end{array}$ & $\begin{array}{r}-1.113 \\
(0.912)\end{array}$ & $\begin{array}{r}0.756 \\
(0.910)\end{array}$ & $\begin{array}{r}0.743 \\
(0.909)\end{array}$ & $\begin{array}{r}-3.226^{* * * *} \\
(1.063)\end{array}$ & $\begin{array}{r}-3.534^{* * * *} \\
(1.119)\end{array}$ & $\begin{array}{r}0.076 \\
(0.925)\end{array}$ & $\begin{array}{l}-0.007 \\
(0.935)\end{array}$ \\
\hline Risk aversion & $\begin{array}{r}-0.010 \\
(0.118)\end{array}$ & $\begin{array}{r}-0.073 \\
(0.127)\end{array}$ & $\begin{array}{r}0.111 \\
(0.126)\end{array}$ & $\begin{array}{r}0.108 \\
(0.125)\end{array}$ & $\begin{array}{l}-0.123 \\
(0.148)\end{array}$ & $\begin{array}{r}-0.180 \\
(0.155)\end{array}$ & $\begin{array}{r}-0.018 \\
(0.130)\end{array}$ & $\begin{array}{l}-0.041 \\
(0.131)\end{array}$ \\
\hline \multicolumn{9}{|l|}{$\begin{array}{l}\text { Village } \\
\text { dummies }\end{array}$} \\
\hline Huaqiangzi & $\begin{array}{r}-0.651 \\
(0.415)\end{array}$ & $\begin{array}{c}-0.942^{* *} \\
(0.446)\end{array}$ & $\begin{array}{r}0.317 \\
(0.449)\end{array}$ & $\begin{array}{r}0.303 \\
(0.446)\end{array}$ & $\begin{array}{l}-0.877^{*} \\
(0.519)\end{array}$ & $\begin{array}{r}-1.102^{* *} \\
(0.542)\end{array}$ & $\begin{array}{r}-0.260 \\
(0.477)\end{array}$ & $\begin{array}{r}-0.333 \\
(0.481)\end{array}$ \\
\hline Hexi & $\begin{array}{c}1.175^{* * *} \\
(0.433)\end{array}$ & $\begin{array}{r}1.234^{* * *} \\
(0.467)\end{array}$ & $\begin{array}{r}1.716^{* * * *} \\
(0.465)\end{array}$ & $\begin{array}{r}1.720^{* * * *} \\
(0.466)\end{array}$ & $\begin{array}{r}-0.832 \\
(0.537)\end{array}$ & $\begin{array}{r}-0.803 \\
(0.564)\end{array}$ & $\begin{array}{c}0.803^{*} \\
(0.471)\end{array}$ & $\begin{array}{r}0.826^{*} \\
(0.476)\end{array}$ \\
\hline $\begin{array}{l}\text { Net rented-in } \\
\text { land }\end{array}$ & $\begin{array}{r}0.423^{* * *} \\
(0.065)\end{array}$ & - & $\begin{array}{r}0.022 \\
(0.071)\end{array}$ & - & $\begin{array}{r}0.338^{* * * *} \\
(0.079)\end{array}$ & - & $\begin{array}{r}0.132 \\
(0.071)\end{array}$ & - \\
\hline Constant & $\begin{array}{r}-0.584 \\
(2.076)\end{array}$ & $\begin{array}{r}0.397 \\
(2.232)\end{array}$ & $\begin{array}{r}-0.328 \\
(2.237)\end{array}$ & $\begin{array}{r}-0.271 \\
(2.230)\end{array}$ & $\begin{array}{r}0.282 \\
(2.720)\end{array}$ & $\begin{array}{r}1.338 \\
(2.859)\end{array}$ & $\begin{array}{r}-2.122 \\
(2.360)\end{array}$ & $\begin{array}{r}-1.917 \\
(2.386)\end{array}$ \\
\hline Sigma & 2.688 & 2.897 & 2.791 & 2.792 & 3.135 & 3.294 & 2.590 & 2.621 \\
\hline Log likelihood & -690.971 & -710.438 & $\begin{array}{r}- \\
601.509\end{array}$ & -601.556 & -563.124 & -571.903 & -395.754 & -397.490 \\
\hline LR test & 260.83 & 221.90 & 62.29 & 62.20 & 168.39 & 150.83 & 58.61 & 55.14 \\
\hline Pseudo $\mathrm{R}^{2}$ & 0.159 & 0.135 & 0.049 & 0.049 & 0.130 & 0.117 & 0.069 & 0.065 \\
\hline $\begin{array}{l}\text { No. of } \\
\text { observations }\end{array}$ & 299 & 299 & 299 & 299 & 299 & 299 & 299 & 299 \\
\hline
\end{tabular}




$$
\text { Chapter } 5
$$

The future of intercropping under growing resource scarcity and declining grain prices in China - A model analysis 


\title{
5. The future of intercropping under growing resource scarcity
}

\section{and declining grain prices in China - A model analysis ${ }^{29}$}

\begin{abstract}
Intercropping, i.e. mixed crop species cultivation on a field, can potentially reduce pressure on land and water resources by generating higher resource use efficiencies and crop yields through exploitation of complementarities between species. Intercropping systems in China and elsewhere have come under pressure through labor migration, growing water scarcity, changing crop prices and other factors. However, little hard evidence is available on how these socio-economic factors interplay and affect the prevalence of intercropping systems now and in the near future. The objective of this study is to explore the effect of growing scarcity of (water and labor) resources and declining (maize) grain prices on the share of intercropping in the optimal cropping plan and on associated agricultural income levels in an intercroppingdominated agricultural system in China. To undertake this analysis, we developed a mathematical programming model to simulate crop production for a model village in Gaotai county in the Hexi Corridor in northwest China, for given resources and economic conditions in 2013 and possible changes (scenarios) in the future. In the Hexi Corridor, conventional wheat/maize intercropping contributed greatly to rising food production while cash crops integrated with maize provided important cash income. With the introduction of seed crops and stricter water regulations, intercropping has become less prevalent in this area in recent years. In the absence of water constraints and at price levels and labor availability in 2013, our model results indicate that an optimal land use would entail that all land would be devoted to intercropping. Sole cumin and sole cotton enter the optimal cropping plan when water
\end{abstract}

\footnotetext{
29 This chapter has been submitted to the Agricultural Systems, as Hong, Y., Berentsen, P., Shi, M., Heerink, N., and van der Werf, W. 'The future of intercropping under growing resource scarcity and declining grain prices in China - A model analysis'.
} 
becomes scarce and the maize price declines substantially, while increases in hired labor wages have a strong negative impact on intercropping only when on-farm labor becomes scarce.

Keywords: Intercropping; Water; Labor; Maize price; China 


\subsection{Introduction}

Intercropping is the cultivation of two or more crop species in the same field for the whole or a part of their growing period (Vandermeer, 1989). Intercropping generally produces more yield per unit of land than sole cropping (Zhang and Li, 2003; Yu et al., 2015) and reduces the risk of crop failure (Horwith, 1985; Lithourgidis et al., 2011). These advantages mainly arise from complementary patterns of resource uptake (light, water and nutrients) between crop species, better nutrient cycling, and through suppression of pests, weeds and diseases (Vandermeer, 1989). Intercropping also has the potential to counteract resource degradation (Lichtfouse, 2009; Feike et al., 2012), it can contribute to increases in soil carbon due to increased root biomass input, and it can increase organic soil nitrogen as a result of better nitrogen cycling (Cong et al., 2015).

In China, intercropping has been practiced for thousands of years (Lichtfouse, 2009), and it is nowadays still popular in some areas across the country (Hong et al., 2017). In northwestern China, the thermal time is not sufficient to grow two sequential crops in one growing season as can be done in more southern parts of the country, but the temperature sum is sufficient to grow two species with partially overlapping growing periods as a relay intercrop ( $\mathrm{Li}$ et al., 2006; Mao et al., 2015; Wang et al., 2015). Relay intercropping boosts yields per unit area (Yu et al., 2015) as a result of higher light capture over the season as compared to sole crops (Zhang et al., 2008; Gou et al., 2017)). Northwestern China therefore has a history of widespread usage of intercropping (Li et al., 2005; Hong et al., 2017).

The Hexi Corridor of Gansu province, northwest China, is characterized by low precipitation and high evaporation. Annual precipitation is less than $160 \mathrm{~mm}$, and two-thirds of the rain falls between July and September (Chai et al., 2014; Sun et al., 2016). Wheat/maize intercropping was developed as a highly productive system in the 1960s and contributed to 
growing food production in the last decades in this area (Li et al., 2005; Yang et al., 2010). This cropping system was made possible by the fertile and flat land, and the availability of irrigation water from inland rivers and infrastructure for water distribution.

Zhangye City is an administrative region in the middle reaches of the Heihe river, which crosses the Hexi corridor from south to north. The Heihe River is an inland river that originates in the Qilian Mountains in Qinghai Province, flows northwards through Gansu Province and ends in Juyanhai Lake in the Inner Mongolia Autonomous Region. The Zhangye region covers 42,100 square $\mathrm{km}$ and has a population of 1.2 million (Gansu Bureau of Statistics, 2014). Zhangye consists of six counties: Gaotai, Ganzhou (district), Shandan, Minle, Linze and Sunan Yugur. Zhangye accounts for about $93 \%$ of all water use from the Heihe river, and $90 \%$ of the water use in Zhangye is for agriculture (Wang et al., 2009; Zhang et al., 2014). Water use per capita is $1,350 \mathrm{~m}^{3}$ per year (60\% of the national average) and yearly water use per $\mathrm{mu}^{30}$ of arable land is $530 \mathrm{~m}^{3}$ (30\% of the national average) (Sun et al., 2016). With economic growth and population increase, water demand for non-agricultural uses is increasing, causing pressure on water use in agriculture (Bao and Fang, 2007; Zhang, 2007).

To reduce the use of water, a "water-saving society" pilot project, the first of its kind in China, was implemented in Zhangye in 2002 (Zhang, 2007). Measures taken include cropping systems adjustment, e.g. through a reduction in water demanding grain crops and a transition to crops with low water use but a high value such as vegetables and seed maize (Chen et al., 2005; Zhou et al., 2015). Seed maize as a water-saving crop requires 500-600 $\mathrm{m}^{3} / \mathrm{mu}$ (equivalent to $750-900 \mathrm{~mm}$ ) and was introduced in 2000. The seed maize area in Zhangye expanded from zero to $32 \%$ of the total agricultural land in 2010 (Zhou et al., 2016). In

\footnotetext{
${ }^{30}$ One mu equals $1 / 15$ hectare.
} 
contrast, wheat/maize intercropping, which requires $700-800 \mathrm{~m}^{3} / \mathrm{mu}$ of irrigation water became less prevalent. Its area in Zhangye dropped from $48 \%$ of the agricultural area in 2000 to $24 \%$ by 2010 (Zhou et al., 2016).

The use of intercropping is likely to be affected by socio-economic factors, such as labor availability and crop prices, which changed during the same period. Intercropping is generally more labor-intensive than sole cropping, while specifically-designed mechanization is scarcely available. Diminishing availability of rural labor as a result of rural-urban migration may therefore induce a switch from intercropping to sole crops.

Output prices are another important determinant of cropping decisions. Several price intervention policies such as minimum procurement prices and the Temporary Storage Program (TSP) have sought to enhance and stabilize farmers' income and promote grain crop production since 2004 (Gale, 2013; Huang and Yang, 2017). The associated high grain prices resulted in a strong growth of grain production, in particular of maize, and a huge increase in the domestic maize stock. In order to alleviate the pressure of this stock, the Chinese government announced a new reform ${ }^{31}$ on maize in 2016 that ended the TSP and the price support for maize. As a result, the maize price was $21 \%$ lower during the first three quarters of 2017 as compared to $2013 .{ }^{32}$ Similar reforms are expected in the future for wheat and rice $(\mathrm{Xu}, 2017)$. In Zhangye, the declining price of maize is likely to have important consequences for the prevalence of intercropping in the future as most intercropping systems are based on maize as one of the component crops of the mixture.

While growing scarcity of water and labor resources and declining grain crop prices are likely to have impacted the use of intercropping in Zhangye City and other parts of China, little is

\footnotetext{
${ }^{31}$ This reform, called Jiabu fenli, separates income support from price policy and allows the maize price to be determined by the market (Huang and Yang, 2017).

${ }^{32}$ Source: http://data.stats.gov.cn/english/easyquery.htm?cn=B01
} 
known about the consequences of these developments for land use decisions and income levels of rural households. Given the relatively high yields and resource use efficiencies of intercrops as compared to single crops (Gou et al., 2017), a decline in their prevalence may have negative consequences for rural household welfare and natural resource quality.

Worldwide, farmers are considered to be the primary decision-makers on cropping plans. In many areas in China, however, farmers have to take village requirements into account when making their own decisions. For example, village leaders may sign contracts with private companies to grow certain crops on a proportion of the village land or even the whole village area (Wang et al., 2014). These contracts are usually translated into cropping obligations for individual households. Moreover, availability of irrigation water during certain fixed periods requires that farmers cultivating adjacent plots need to coordinate their cropping decisions with each other. This situation also applies to Zhangye. It is therefore more appropriate to study cropping decisions at the village level than at the single household level.

The objective of this study is to explore the effects of growing resource (water and labor) scarcity and declining (maize) grain prices on the share of intercropping in the optimal cropping plan and associated agricultural income levels in an intercropping-dominated agricultural system in China. To this end, we developed a mathematical programming model at village level to identify the crop practices that will be included in the optimal land use and the consequences for the gross margin at village level of different scenarios for resource constraints and output prices. 


\subsection{Materials and methods}

\subsubsection{Study area and data collection}

From August to November 2014, survey teams from Northwest Agricultural and Forestry University (NWAFU) in Yangling, Shaanxi Province and the University of the Chinese Academy of Sciences (UCAS) in Beijing conducted a survey in the Heihe River Basin in Gansu province and Inner-Mongolia. The main goal of the survey was to assemble information on farm household livelihoods and water use in different parts of the river basin. Data were collected on use of inputs and outputs in agricultural production, consumption and expenditure, and farmers' attitude towards the current water policy.

The data used in this study were obtained from a sub-sample for Luocheng township in Gaotai County Zhangye City, Gansu Province and an additional survey, conducted by the first author, in the same township. Villages in Luocheng township used intercropping in the past and still use it. We randomly selected three out of 13 villages in Luocheng township: Luocheng village, Huaqiangzi village and Hexi village. Within each village, interviewees were randomly selected among the households that were present in the village at the time of the farm survey. In total, 320 farm household heads ${ }^{33}$ (102 in Luocheng, 134 in Huaqiangzi, and 84 in Hexi) were interviewed during the 2013 agricultural season. Out of these 320 household heads, 111 did not provide complete information on major variables in our analysis, like irrigation water or labor inputs. These households were excluded from the sample. The sample used for the analysis therefore includes 209 households.

Additional background information was collected through field visits and talking to local officials and experts. For cross-checking crop yields of intercropping, we consulted experts

\footnotetext{
${ }^{33}$ For those household heads that were absent during our interview, we interviewed one of the other family members with sufficient knowledge about farming practices.
} 
from China Agricultural University, who have experience in the research of intercropping in Gansu province. Besides, one of the authors paid a visit to the surveyed villages in the summer of 2017 to collect further information on e.g. rotation and water requirements of crops. Staff in the Luocheng Water Management Bureau (WMB), the agency responsible for water distribution and management in the district, provided us with information on the methods used for measuring water use in agriculture and on recent price developments.

The model village that we use in this study is derived from the data collected in the three surveyed villages. All household level variables are calculated as an average for the 209 surveyed households in the three villages. Village level variables, such as the total land area, are calculated as the average for the three villages and reflect the total land area per village in Luocheng township.

\subsubsection{Model specification}

The optimization problem is to maximize the gross margin of the whole village subject to a set of constraints:

Maximize $G M=\sum_{i=1}^{8} x_{i}\left(p_{i} y_{i}-c_{i}-w_{i} p_{w}\right)-\sum_{m=1}^{9} L H_{m} p_{l h}$

\section{Subject to}

Irrigation water

$$
\begin{gathered}
\sum_{i=1}^{8} w_{i} x_{i} \leq W \\
W=A Q
\end{gathered}
$$

Labor

$$
\begin{gathered}
L_{m}=L F_{m}-L O_{m} \\
\sum_{i=1}^{8} x_{i} L_{m i} \leq L_{m}+L H_{m}
\end{gathered}
$$

Land

$$
\sum_{i=1}^{8} x_{i} \leq A
$$

Rotation requirements

$$
x_{5}+x_{8} \leq 1 / 3 A
$$




$$
x_{4}+x_{7} \leq 1 / 2 A
$$

Non-negative planting areas $\quad x_{i} \geq 0$ for $\mathrm{i}=1,2, \ldots, 8$

Where

Subscript $i$ is the $i$ th crop type $(\mathrm{i}=1,2, \ldots, 8), m$ is the $m$ th month $(\mathrm{m}=1,2, \ldots, 9)$

$G M$ total gross margin of crop production in the village (CNY)

$x_{1}$ area of cotton $(\mathrm{mu})$

$x_{2}$ area of sole wheat $(\mathrm{mu})$

$x_{3}$ area of sole maize $(\mathrm{mu})$

$x_{4}$ area of sole cumin $(\mathrm{mu})$

$x_{5}$ area of sole seed watermelon $(\mathrm{mu})$

$x_{6}$ area of wheat/maize intercropping (mu)

$x_{7}$ area of cumin/maize intercropping (mu)

$x_{8}$ area of seed watermelon/maize intercropping (mu)

$p_{i}$ output price of $i$ th crop $(\mathrm{CNY} / \mathrm{jin})$

$y_{i}$ yield of $i$ th crop per unit area $(\mathrm{jin} / \mathrm{mu})$

$c_{i}$ production cost of the $i$ th crop per unit, excluding costs of irrigation and hired labor

$w_{i}$ volume of irrigation water for $i$ th crop $\left(\mathrm{m}^{3} / \mathrm{mu}\right)$

$p_{w}$ price of irrigation water $\left(\mathrm{CNY} / \mathrm{m}^{3}\right)$

$L$ total labor input (man day)

$L F_{m}$ family labor availability (man day)

$L H_{m}$ hired labor (man day)

$p_{l h}$ price of hired labor (CNY/man day)

$L O_{m}$ monthly off-farm labor (man day)

$L_{m i}$ labor requirement for the $i$ th crop in $m$ th month (man day)

$L_{m}$ labor availability of the $m$ th month (man day)

$W$ total irrigation quota $\left(\mathrm{m}^{3}\right)$

$Q$ irrigation quota $\left(\mathrm{m}^{3} / \mathrm{mu}\right)$

$A$ total land area $(\mathrm{mu})$ 
Gross margin is defined as the total revenue across the village from sales of crop output minus variable costs. Variable costs are cost of seeds, fertilizers, pesticides, film mulch, hired machinery, irrigation water and hired labor. The constraints include availability of three main resources, irrigation water (Eq. (2) and (3)), labor (Eq. (4) and (5)) and land (Eq. (6)), and rotation requirements of watermelon and cumin (Eq. (7) and Eq. (8)). The output of the model includes the optimal crop production plan and associated gross margin.

The model includes 8 main crop activities: sole cotton, sole maize, sole wheat, sole cumin, sole watermelon (seed), maize/wheat intercropping, maize/cumin intercropping and maize/watermelon intercropping. In the study region, farmers engage also in animal husbandry. Animal husbandry activities are, however, not included in our model as the purpose of this study is to explore the optimal planning of crop activities and not to model the entire farming system. The area under the 8 selected crop activities in the village accounted for over $90 \%$ of its total land area in 2013. Table 5.1 provides information on yields, output prices and variable costs of the selected crop activities while Table 5.2 provides the labour requirement per crop per month. Crop rotation is required to avoid or reduce diseases and insects that are associated with consecutive cultivation of the same crop on the same plot. Local farmers plant sole watermelon and seed watermelon/maize intercropping not more than once every three years in the same plot. Sole cumin and cumin/maize is planted not more than once every two years. These rotation requirements translate into constraints on the maximum area of a certain crop (Eq.(7) and Eq. (8)). 


\subsubsection{Resource availability and requirement}

\section{Irrigation water}

Irrigation is required to produce crops in this desert area. In China, government authorities manage and allocate water resources to users through governmental orders and water quotas. Water quota systems are hierarchically controlled and managed in Zhangye City (Zhang and Zhang, 2008). The Zhangye Municipal Government determines the water quotas for each of the six counties under its jurisdiction. Each county-level government (e.g. Gaotai) distributes its water quota to townships, each township distributes its water quota to villages, and villages allocate their water quota to farm households.

Water agencies manage the water quota and the collection of water fees on behalf of the government (Zhang et al., 2009). For our case, Luocheng Water Management board (WMB) is the water agency that decides when and how much water (total water quota) is allocated to each village. The WMB draws water from the Heihe River between March to November. It provides irrigation water to villages via an agreed number of irrigation rounds. Therefore, water quota can be expressed in terms of the number of irrigation rounds. In this region with very low precipitation, seed watermelon receives $70-80 \mathrm{~m}^{3} / \mathrm{mu}$ per round while other crops receive around $100 \mathrm{~m}^{3} / \mathrm{mu}$ (i.e. $150 \mathrm{~mm}$ ) per round (source: Luocheng WMB and own field visit).

In the model, the availability of water for crop production is the total water quota expressed in Eq. (2). Total water quota is the product of total land area (mu) and water quota per mu $\left(\mathrm{m}^{3} / \mathrm{mu}\right.$ ) (Eq. (3)). The water quota for Gaotai county was $814 \mathrm{~m}^{3} / \mathrm{mu}$ in 2013 (source: Luocheng WMB). The available water quota per mu exceed any crop requirement (Table 5.1). Therefore, the water quota was not binding in 2013. 
Table 5.1 Yield, price, revenue, variable costs, gross margin and water requirement per cropping activity (baseline year 2013)

\begin{tabular}{|c|c|c|c|c|c|c|c|c|c|}
\hline & \multirow[b]{2}{*}{ Unit } & \multicolumn{5}{|c|}{ Sole crops } & \multicolumn{3}{|c|}{ Intercropping } \\
\hline & & Cotton & Maize & Wheat & Cumin & $\begin{array}{l}\text { Seed } \\
\text { water- } \\
\text { melon }\end{array}$ & Maize/wheat & Maize/cumin & $\begin{array}{l}\text { Maize/seed } \\
\text { watermelon }\end{array}$ \\
\hline \multirow[t]{2}{*}{ Yield $^{\mathrm{a}}$} & \multirow{2}{*}{$\begin{array}{l}\mathrm{Jin} / \\
\mathrm{mu}\end{array}$} & 286.2 & 1088 & 774 & 151.4 & 67.5 & 917.3 (maize) & 938 (maize) & 935.2 (maize) \\
\hline & & & & & & & 632.5 (wheat) & $\begin{array}{l}131.9 \\
\text { (cumin) }\end{array}$ & $\begin{array}{l}66.3 \text { (seed } \\
\text { watermelon) }\end{array}$ \\
\hline \multirow[t]{2}{*}{ Price $^{b}$} & \multirow{2}{*}{$\begin{array}{l}\text { CNY/ } \\
\text { jin }\end{array}$} & 4.2 & 1.0 & 1.0 & 8.5 & 58.1 & 1.0 (maize) & 1.0 & 1.0 \\
\hline & & & & & & & 1.0 (wheat) & 8.5 (cumin) & $\begin{array}{l}58.1 \text { (seed } \\
\text { watermelon) }\end{array}$ \\
\hline Revenue & $\begin{array}{l}\mathrm{CNY/} \\
\mathrm{mu}\end{array}$ & 1,191 & 1,066 & 790 & 1,287 & 3,922 & 1,544 & 2,040 & 4,769 \\
\hline $\begin{array}{l}\text { Variable } \\
\text { costs }^{\mathrm{c}}\end{array}$ & $\begin{array}{l}\mathrm{CNY/} \\
\mathrm{mu}\end{array}$ & 647 & 558 & 436 & 236 & 511 & 561 & 521 & 599 \\
\hline $\begin{array}{l}\text { Gross } \\
\text { margin }\end{array}$ & $\begin{array}{l}\mathrm{CNY} / \\
\mathrm{mu}\end{array}$ & 544 & 508 & 354 & 1051 & 3,411 & 984 & 1,519 & 4,170 \\
\hline $\begin{array}{l}\text { Water } \\
\text { require- } \\
\text { ment }^{\mathrm{d}}\end{array}$ & $\begin{array}{l}\mathrm{m}^{3} / \\
\mathrm{mu}\end{array}$ & 311 & 622 & 422 & 43 & 404 & 703 & 530 & 670 \\
\hline
\end{tabular}

Source: Own survey, NWAFU-UCAS survey and expert consultation

a Yield of each crop equals the mean value for land areas planted with the crop collected from the household survey in 2014; yields in the last 3 columns are yields of component crops in intercropping.

b Input and output prices were also collected in the household survey, prices for intercrops are given for each of the component crops.

c Variable costs include costs of seeds, fertilizers, pesticides, film mulch, hired machinery and irrigation water; costs of hired labor are not included.

d Water requirements for each crop were estimated by combining information from the household survey with information obtained from experts from China Agricultural University and through field visits by the authors.

The irrigation water fee consists of a basic water price ${ }^{34}$ and a volumetric cost. The basic water price was between 2-4 CNY/mu in 2014 in Zhangye (Sun et al., 2016). We use an average value of $3 \mathrm{CNY} / \mathrm{mu}$ in our study. The volumetric price was $0.11 \mathrm{CNY} / \mathrm{m}^{3}$ in 2013 in Gaotai county (Zhang and Xue, 2016).

\footnotetext{
${ }^{34}$ This is a fixed cost charge for water management services.
} 


\section{Labor}

Family labor is the dominant source of labor input, while farmers may also hire labor during the peak season. Family labor may be allocated to on-farm crop production and off-farm employment (e.g. in construction work). The monthly availability of labor $\left(L_{m}\right)$ is the difference between the monthly available family labor $\left(L F_{m}\right)$ and the monthly off-farm labor $\left(\mathrm{LO}_{m}\right)$ (Eq. 4). The monthly labor use for crop production is the sum of monthly available labor $\left(L_{m}\right)$ and the monthly hired labor $\left(L H_{m}\right)$ (Eq. 5). The monthly available family labor is measured as the number of family workers times the working days per laborer. We assume that each worker can work 25 days per month. Off-farm labor is the total number of off-farm working days for all workers in the village. We asked the household head to re-count the working days on off-farm employment in each month for each worker in the family. The resulting survey data on available family labor and off-farm labor are given in Table 5.2. 
Table 5.2 Labor requirements of different crop systems and labor availability across the season

\begin{tabular}{|c|c|c|c|c|c|c|c|c|c|c|}
\hline & March & April & May & June & July & August & September & October & November & $\begin{array}{l}\text { Total } \\
\text { labor }\end{array}$ \\
\hline \multicolumn{11}{|l|}{$\begin{array}{l}\text { Labor } \\
\text { requirement } \\
\text { (man days per } \\
\text { mu) }\end{array}$} \\
\hline Cotton & & 1.8 & 1.6 & 1.7 & 0.2 & & 6.5 & 0.7 & & 12.5 \\
\hline Sole maize & & 1.5 & 1.1 & 0.4 & 0.6 & 0.4 & 0.3 & 2.2 & & 6.5 \\
\hline Sole wheat & 1.5 & & 1.1 & 1.0 & 1.7 & & & 0.3 & 0.5 & 6.1 \\
\hline Sole cumin & 1.2 & 0.9 & 1.0 & 2.2 & & & & 1.1 & 0.2 & 6.6 \\
\hline $\begin{array}{r}\text { Sole seed } \\
\text { watermelon }\end{array}$ & & & 3.0 & $34.5^{\mathrm{a}}$ & 1.5 & 3.5 & & 0.27 & 0.3 & 43.1 \\
\hline Wheat/maize & 1.6 & 1.9 & 3.1 & 2.1 & 2.4 & 0.9 & 0.6 & 2.1 & 1.1 & 15.8 \\
\hline Cumin/maize & 1.5 & 2.0 & 1.6 & 0.6 & 2.1 & 0.8 & 1.0 & 1.8 & 1.1 & 12.5 \\
\hline $\begin{array}{r}\text { Seed } \\
\text { watermelon/maize }\end{array}$ & & 3.7 & 1.9 & 34.4 & 1.1 & 2.3 & 0.9 & 2.0 & 0.9 & 47.2 \\
\hline \multicolumn{11}{|l|}{$\begin{array}{l}\text { Labor } \\
\text { availability } \\
\text { (man days) }\end{array}$} \\
\hline $\begin{array}{r}\text { Family labor } \\
\text { availability }\end{array}$ & 4,425 & 4,425 & 4,425 & 4,425 & 4,425 & 4,425 & 4,425 & 4,425 & 4,425 & 39,825 \\
\hline $\begin{array}{r}\text { Off-farm labor } \\
\text { activity }^{\mathrm{c}}\end{array}$ & 957 & 1,127 & 1,147 & 977 & 1,002 & 1,077 & 1,092 & 927 & 733 & 9,039 \\
\hline
\end{tabular}

Source: Author's survey and expert consultation

a The pollination of watermelon is conducted by hand in June. One mu of pollination requires two persons to work 15 to 18 days (source: Luocheng Water Management Bureau, personal communication). We used an average labor requirement of 16.5 man day per mu for pollination.

b Family labor availability is the product of the number of workers in the family and the number of working days per worker (25 days/month).

c Off-farm labor activity is the total number of off-farm working days of all workers in interviewed households in the village. 


\section{Land}

Land is closely associated with irrigation in the study region, because irrigation is crucial for growing crops in the region (Shi et al., 2014). The cultivated land area in the model village is $653.4 \mathrm{mu}(43.6 \mathrm{ha})^{35}$, i.e. $9.4 \mathrm{mu}$ per household.

\subsubsection{Scenarios}

The model objective is to maximize the total gross margin of the village subject to various constraints. The optimal cropping plan of the whole village might change because of changes in the availability of crucial resources and in output prices. We defined 2 scenarios plus 3 sensitivity analyses for the baseline scenario. They are summarised in Table 5.3.

Scenario 1 is the baseline reflecting water quota and pricing of inputs and outputs of 2013. There is no water quota in the scenario 1 . In this case, we aim to identify the optimal crop plan and associated margin when water is not limiting.

In sensitivity analysis 1 , we explore how the optimal crop plan and associated gross margin respond when water becomes more scarce. The prices of inputs and outputs are the same as in the baseline but a water quota constraint is imposed. We do the simulation from a water quota that equals zero, then add $100 \mathrm{~m}^{3}$ for each step until the water quota equals $800 \mathrm{~m}^{3}$. A water quota of $800 \mathrm{~m}^{3}$ exceeds the water requirements of all crops and is consistent with the reference situation of 2013 (Table 5.1).

In sensitivity analysis 2 , we explore how the optimal crop plan and associated gross margin respond when the maize price decreases. In this analysis, the maize price is $10 \%$ to $90 \%$ lower than in the baseline and there is no water quota. In 2013 the maize price was $1.0 \mathrm{CNY} / \mathrm{jin}$ (500 g), so the maize price ranges from $0.1 \mathrm{CNY} / \mathrm{jin}$ to $0.9 \mathrm{CNY} / \mathrm{jin}$.

\footnotetext{
${ }^{35}$ Note that the total area reflects the area of interviewed households only.
} 
In sensitivity analysis 3, we explore whether higher wages and off-farm employment could drive intercropping out of existence. We increase labor wages up to a wage which is five times the 2013 baseline of $96 \mathrm{CNY} / \mathrm{man}$ day, and do this at four levels of off-farm employment representing different levels of availability of on-farm labor for agriculture. Level one represents the 2013 baseline level of off-farm employment. Levels two, three and four represent, respectively, two, three and four times this baseline level of off-farm employment.

In scenario 2, the effects of a combination of changes is analysed to explore the future of intercropping under possible future developments. Based on historic trends, current data and policy documents, we set the water quota at $640 \mathrm{~m}^{3} / \mathrm{mu}$, the maize price is $20 \%$ lower than the baseline, the labor wage twice its baseline value and the off-farm employment is the same as the baseline.

Table 5.3 Overview of scenarios

\begin{tabular}{|c|c|c|c|c|c|c|}
\hline & & \multicolumn{4}{|c|}{ Scenario 1 (S1) } & \multirow{3}{*}{$\begin{array}{l}\text { Scenario } 2 \\
(\mathrm{~S} 2)\end{array}$} \\
\hline & & \multirow{2}{*}{$\begin{array}{c}\text { Baseline } \\
2013\end{array}$} & \multirow{2}{*}{$\begin{array}{l}\text { Sensitivity } \\
\text { analysis } 1\end{array}$} & \multirow{2}{*}{$\begin{array}{l}\text { Sensitivity } \\
\text { analysis } 2\end{array}$} & \multirow{2}{*}{$\begin{array}{l}\text { Sensitivity } \\
\text { analysis } 3\end{array}$} & \\
\hline & & & & & & \\
\hline Water quota & Quantity $\left(\mathrm{m}^{3} / \mathrm{mu}\right)$ & Unlimited & $0-800$ & Unlimited & Unlimited & 640 \\
\hline Output price & Maize (CNY/jin) & 1 & 1 & $0.1-0.9$ & 1 & 0.8 \\
\hline Hired labor & $\mathrm{CNY} / \mathrm{man}$ day & 96 & 96 & 96 & $96-480$ & 192 \\
\hline \multicolumn{7}{|l|}{ wage } \\
\hline Off-farm & Man day/yearly & 9,039 & 9,039 & 9,039 & $9,039-36,156$ & 9,039 \\
\hline employment & & & & & & \\
\hline
\end{tabular}

\subsubsection{Uncertainty analysis on the value of LER}

The land equivalent ratio (LER) is defined as the relative land area required as sole crops to produce the same yields as intercropping; it can be used as index of the relative productivity 
of intercropping systems as compared to sole crops (Mead and Willey, 1980). The values of the LERs for the three intercropping systems that we compare in this study equal 1.66 for wheat/maize, 1.73 for cumin/maize and 1.84 for seed watermelon/maize. These values are calculated from the farm household data that we collected, and are higher than the LERs that are usually obtained from agronomic experiments. A recent meta-analysis of LERs for annual intercrops found that the worldwide average LER equals $1.22 \pm 0.02$ (Yu et al., 2015). A possible explanation for the higher values that we obtained in our survey is that farm households in the region tend to grow intercrops, which tend to require more labor than sole crops, on the best quality land (source: Informal interviews with local farmers and with the Luocheng WMB).

Considering the large difference between the LERs that we found and those reported in the literature, we performed an uncertainty analysis by exploring the effect of different levels of LER on the optimal cropping plan. To do so, we adjust the LERs of the three intercrops by reducing their values of LERs by $5 \%$ to $40 \%$. For example, a reduction of the LER of wheat/maize by $5 \%$ implies an LERs of $1.66 * 0.95=1.577$. The partial yields for both crops were reduced by the same factor. 


\subsection{Results}

\subsubsection{Scenario analysis and sensitivity analysis}

Under the 2013 baseline of scenario 1 (S1), the model allocates all land to intercropping (Table 5.4). Seed watermelon/maize has the highest gross margin and covers one third of the total land area, which is the maximum area it can cover under the rotation constraint for watermelon (1/3). Sole watermelon is not included because it has lower gross margin than the intercrop with maize, and cannot be grown because of the rotation constraint. Cumin/maize provides the third highest gross margin, after the seed watermelon/maize intercrop and sole seed watermelon. The model assigns the largest share (50\%) of total land to this intercrop; this is the maximum area it can cover under the rotation constraint for cumin (1/2). The remainder of the available land is allocated to wheat/maize which has the highest gross margin of the remaining crops (except sole cumin).

In comparison with the actual situation in 2013 , the gross margin in the optimal solution is $20.6 \%$ higher (Table 5.4). More land is allocated in baseline S1 to the most profitable intercrops, seed watermelon/maize and cumin/maize, as compared to the actual situation, while less land is allocated to the traditional wheat/maize intercrop and no land to sole crops.

The labor use distribution of baseline S1 is presented in Figure 5.1. June is the peak season, when the pollination of seed watermelon occurs. The results show that 4,469 man days of hired labour are needed in June. The amount of labor that has to be hired changes the perspective on the gross margin of seed watermelon and seed watermelon/maize. If all labor in June would be assumed hired labor, the labor cost are 3,264 CNY/mu. This would decreases the gross margin of watermelon/maize to $906 \mathrm{CNY} / \mathrm{mu}$, which is much more in line with the gross margins of other crops. 
Table 5.4 Optimal crop plan of baseline S1 and actual situation in 2013

\begin{tabular}{|c|c|c|}
\hline Scenario & $\begin{array}{r}\text { S1 Baseline } \\
2013\end{array}$ & $\begin{array}{r}\text { Actual situation } \\
2013\end{array}$ \\
\hline \multicolumn{3}{|l|}{ Optimal cropping plan (mu) } \\
\hline Cotton & & 96 \\
\hline Sole maize & & 64 \\
\hline Sole wheat & & 40 \\
\hline Sole cumin & & 6 \\
\hline Sole watermelon (seed) & & 25 \\
\hline Wheat/maize intercropping & 109 & 178 \\
\hline Cumin/maize intercropping & 327 & 171 \\
\hline $\begin{array}{l}\text { Seed watermelon/maize } \\
\text { intercropping }\end{array}$ & 218 & 75 \\
\hline Total revenue $(1,000 \mathrm{CNY})$ & 1,873 & 1,295 \\
\hline $\begin{array}{l}\text { Total variable cost }(1,000 \mathrm{CNY}) \text { (without hired } \\
\text { labor) }\end{array}$ & 362 & 363 \\
\hline Hired labor costs $(1,000 \mathrm{CNY})$ & 429 & 34 \\
\hline Total gross margin $(1,000 \mathrm{CNY})$ & 1,082 & 897 \\
\hline Total water use $\left(\mathrm{m}^{3}\right)$ & 395,634 & 362,232 \\
\hline Total hired labor (man day) & 4,469 & \\
\hline
\end{tabular}

Note: Gross margin = Revenue - variable cost (without costs of hired labor) - hired labor costs (see Eq.(1), section 5.2.2)

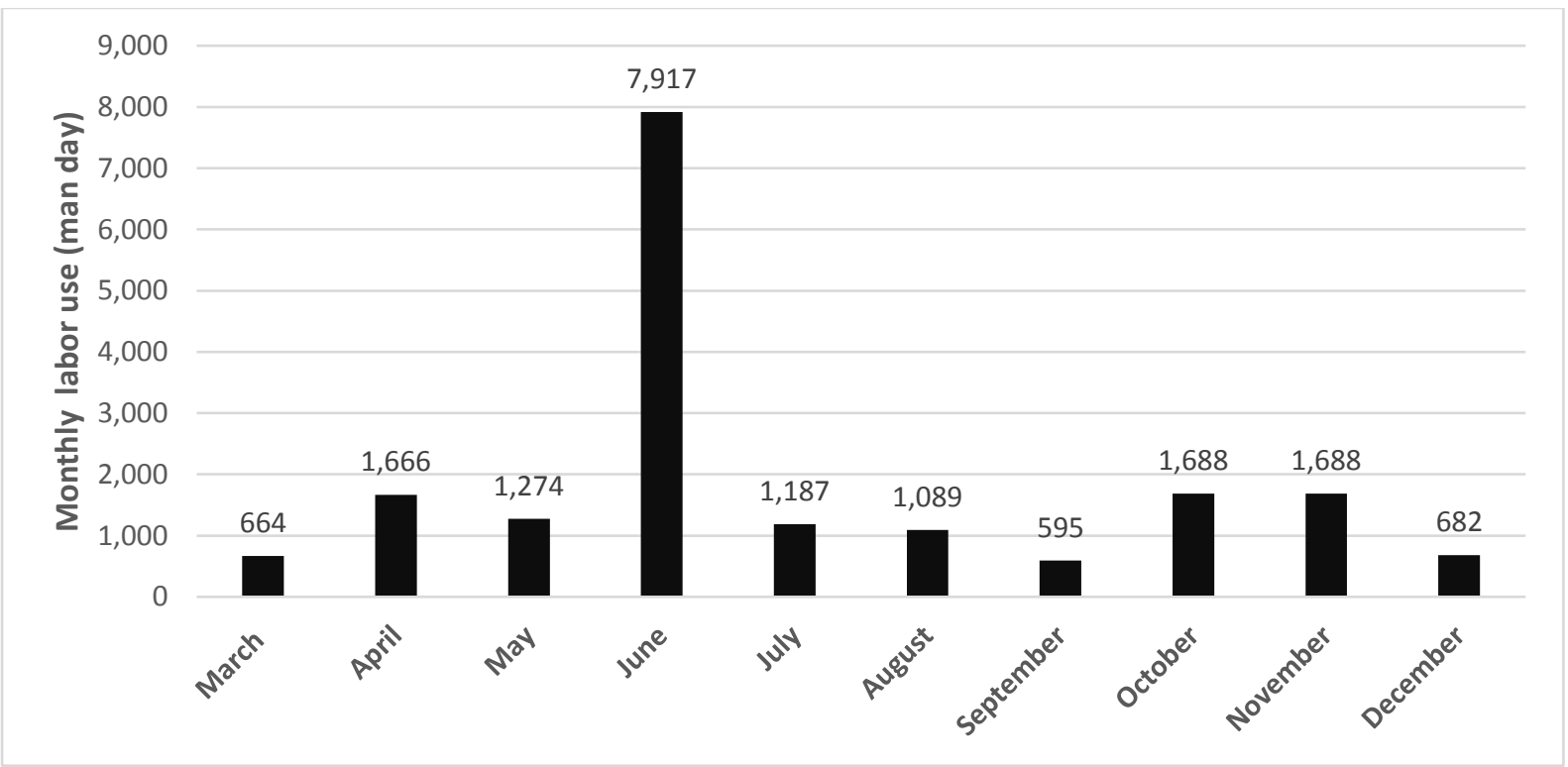

Figure 5.1 Monthly labor use in the baseline scenario.

In sensitivity analysis 1 , the consequences of different levels of water constraint are explored

(Figs 5.2, 5.3). No crop can be planted when there is no irrigation water. When water is very 
scarce, i.e. water quota from 0 to $100 \mathrm{~m}^{3}$ (per mu), 0 to $11.1 \%$ of the land is planted with seed watermelon/maize and 0 to $50 \%$ of the with land sole cumin. When the water quota ranges from $100 \mathrm{~m}^{3}$ to $200 \mathrm{~m}^{3}$, seed watermelon/maize is planted on $11.1 \%$ to $26.6 \%$ of the total land because of its superior profitability. But the drought-tolerant crop, sole cumin, dominates the cropping plan, accounting for $50 \%$ of the total land. The rest of the land remains unused as all the available water is consumed by sole cumin and seed watermelon/maize intercropping when the water quota does not exceed $200 \mathrm{~m}^{3}$. When water availability increases, i.e. water quota is between $200 \mathrm{~m}^{3}$ and $600 \mathrm{~m}^{3}$, the optimal cropping plan becomes more diversified. More seed watermelon/maize and cumin/maize are planted. Sole cumin is gradually replaced by cumin/maize intercropping, which has a higher profitability but also requires much more water (see Table 5.1). Land is still not fully used when the water quota is between $300 \mathrm{~m}^{3}$ and $500 \mathrm{~m}^{3}$; idle land accounts for $16.7 \%$ to $12.9 \%$ of the total land. Finally, when the water quota exceeds $500 \mathrm{~m}^{3}$, wheat/maize intercropping gradually replaces sole cotton and is increasingly planted on idle land. Wheat/maize has a higher profitability than sole cotton, but also has the highest water requirements of all crops (see Table 5.1). When the water quota exceeds 700 $\mathrm{m}^{3}$, the entire land area is planted with intercrops.

The effect of the water quota on the gross margin is shown in Figure 5.2. When the water quota increases from zero to $100 \mathrm{~m}^{3}$ (per mu), the gross margin of the village increases sharply from zero to $669,000 \mathrm{CNY}$. This is almost entirely due to the cultivation of the profitable, drought-resistant crop cumin. When the water quota increases from $100 \mathrm{~m}^{3}$ to 600 $\mathrm{m}^{3}$, the gross margin increases by $61.3 \%$ due to the gradual introduction of intercrops. When the water quota exceeds $600 \mathrm{~m}^{3}$, the gross margin hardly changes anymore as no land is left idle and the crop plan almost does not change. 


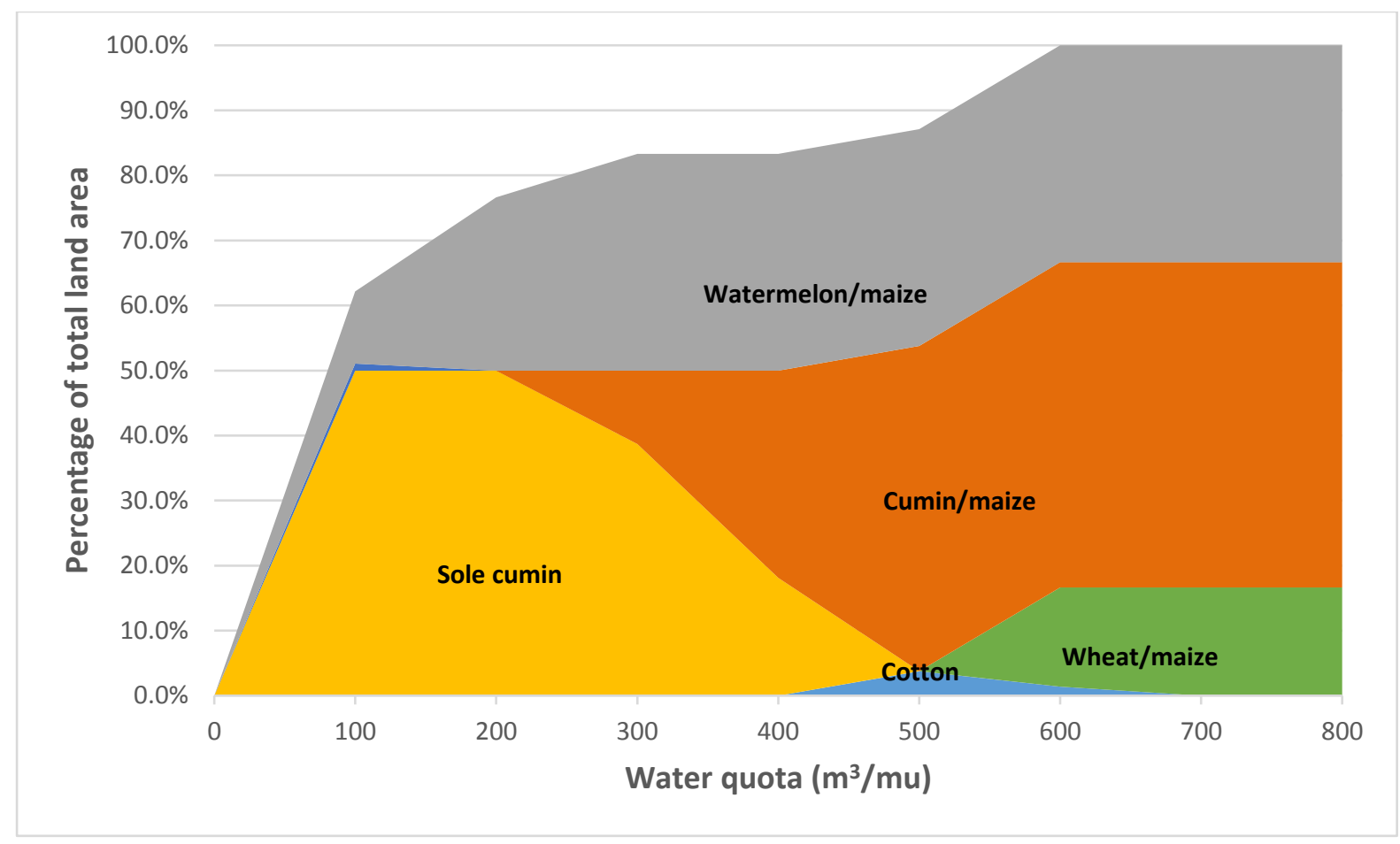

Figure 5.2 Water quota and optimal cropping area (Sensitivity analysis 1)

Note: $100 \mathrm{~m}^{3} / \mathrm{mu}$ is equivalent to $150 \mathrm{~mm}$ irrigation.

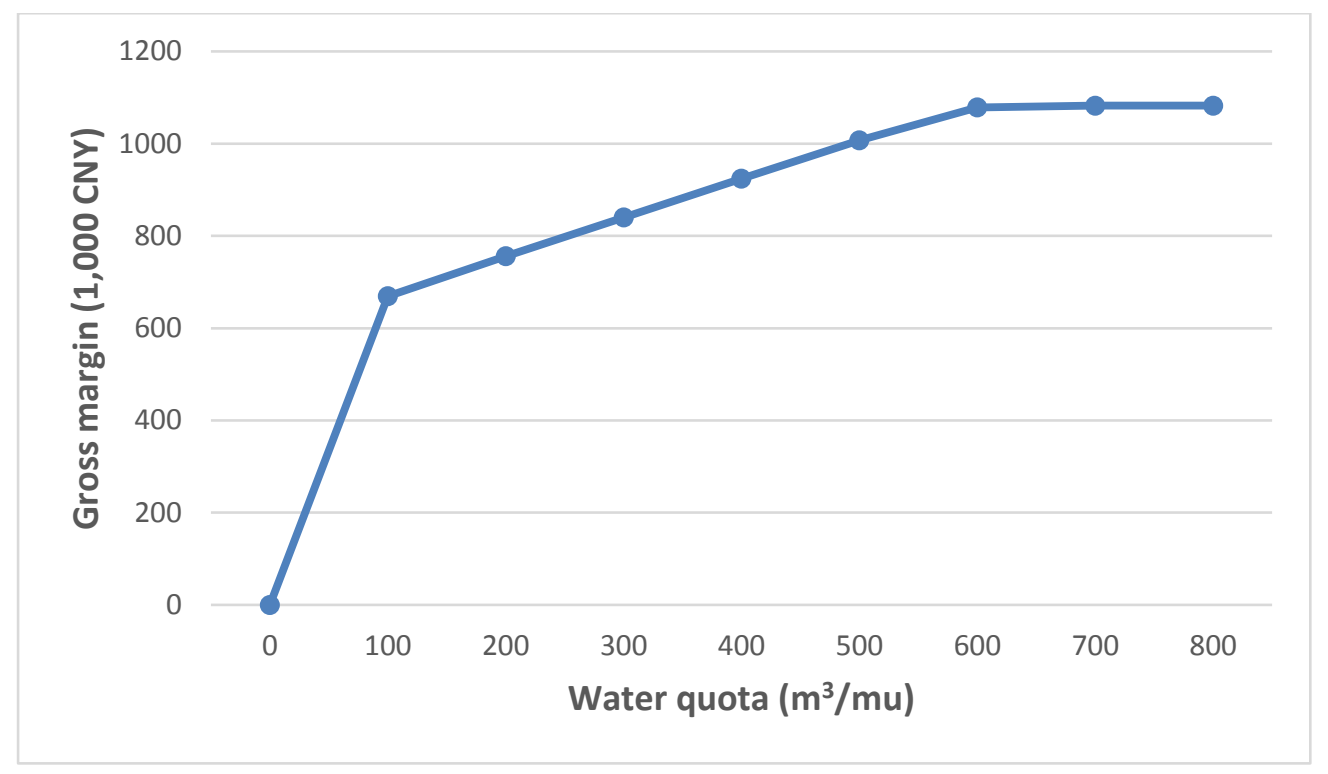

Figure 5.3 Water quota and gross margin (Sensitivity analysis 1) 
Results of sensitivity analysis 2 , declining maize prices, indicate that the maize price plays an important role in the optimal crop plan (Fig. 5.4). Seed watermelon/maize is included in the optimal crop plan, because it is profitable when the maize price ranges between $0.17-1.0$ $\mathrm{CNY} /$ jin. However, at a maize price below $0.5 \mathrm{CNY} / \mathrm{jin}$ the gross margin of watermelon/maize is too low to cover the costs of hired labor in June. Consequently, the cropping plan is changed such that only family labor is used. Seed watermelon/maize is totally replaced by sole watermelon when the maize price is reduced by more than $83 \%$, to a price below $0.17 \mathrm{CNY} / \mathrm{jin}$. The additional costs involved in intercropping seed watermelon with maize exceed the value of the higher yields obtained in the intercropping system for such low maize prices. For similar reasons, cumin/maize is replaced by sole cumin when the maize price is reduced by $70 \%$ or more. Wheat/maize intercropping is more profitable than all sole crops as long as the maize price exceeds $0.5 \mathrm{CNY} / \mathrm{jin}$. When the maize price decreases $50 \%$ or more, it is replaced by sole cotton in the optimal land use plan.

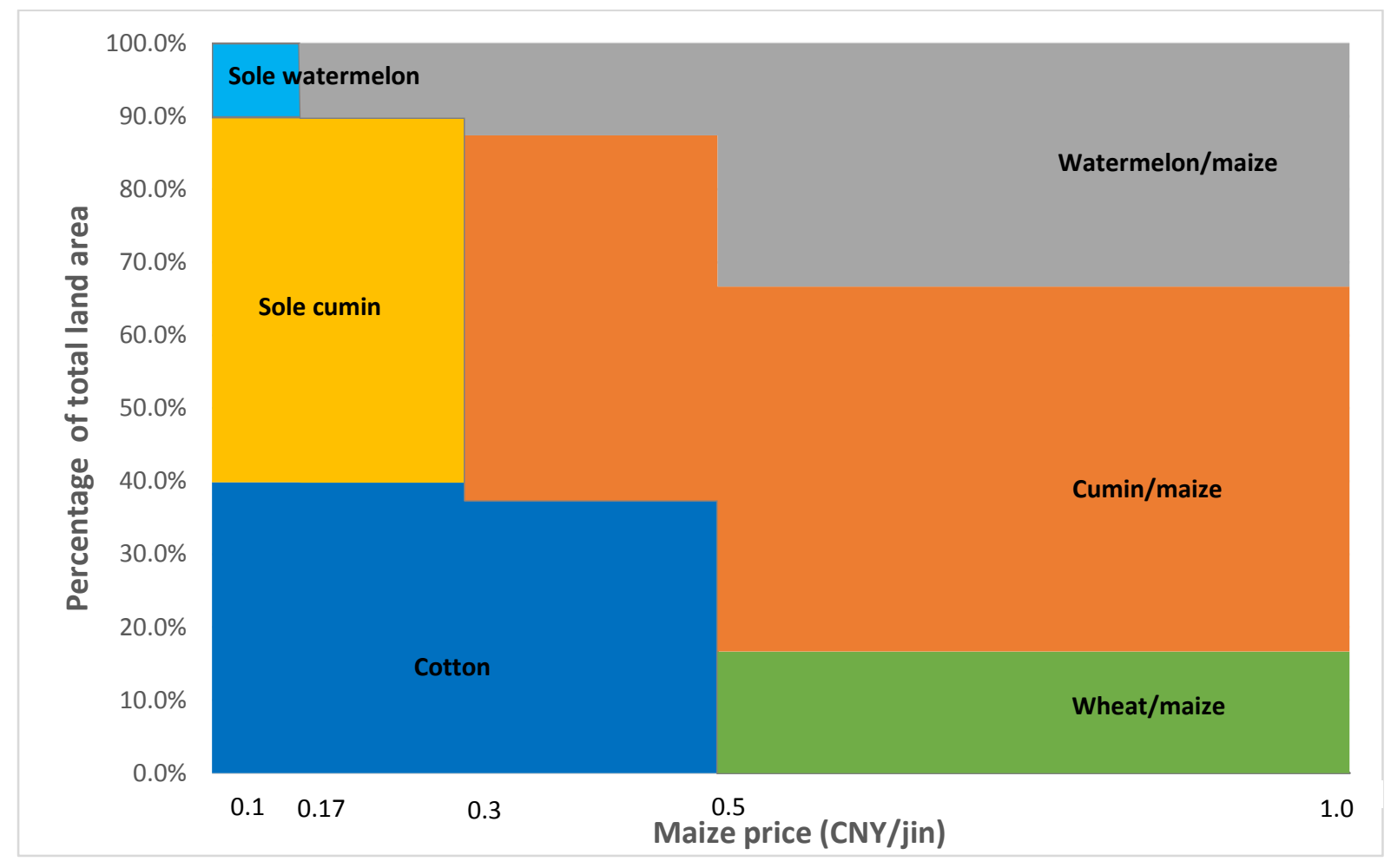

Figure 5.4 Maize price and optimal crop plan (Sensitivity analysis 2) 
Gross margin decreases by $34.3 \%$ when maize price decreases from 1.0 to $0.3 \mathrm{CNY}$ per jin. This is caused by the reduced profitability of maize-based intercrops. Maize-based intercrops are no longer part of the optimal land use plan at a maize price below $0.17 \mathrm{CNY}$ per jin, and the gross margin is therefore not affected by the maize prices below $0.17 \mathrm{CNY}$ per jin.

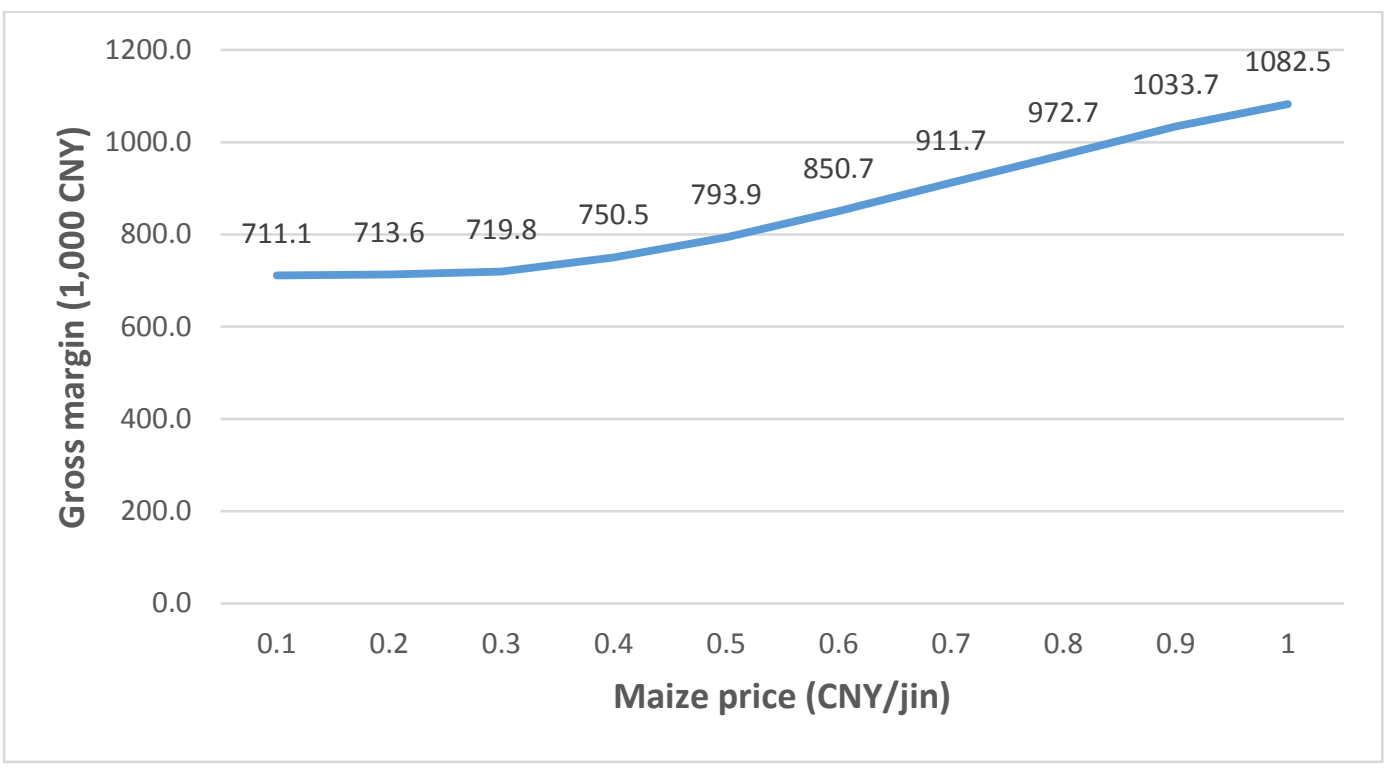

Figure 5.5 Maize price and gross margin (Sensitivity analysis 2)

The effect of rising labor wages was explored at four levels of family labor availability.

Figures 5.6 - 5.9 show the results for off-farm employment levels that equal 1, 2, 3, and 4 times the baseline, respectively. ${ }^{36}$ At each level of off-farm employment, wages ranging from $96 \mathrm{CNY} /$ day (= baseline wage) up to $480 \mathrm{CNY} /$ day (= five times baseline wage) were examined.

\footnotetext{
${ }^{36}$ When off-farm employment by family members equals 4 times the baseline, the on-farm family labor availability (man day) in April and May becomes negative. For these two months we set on-farm availability of family labor equal to zero.
} 


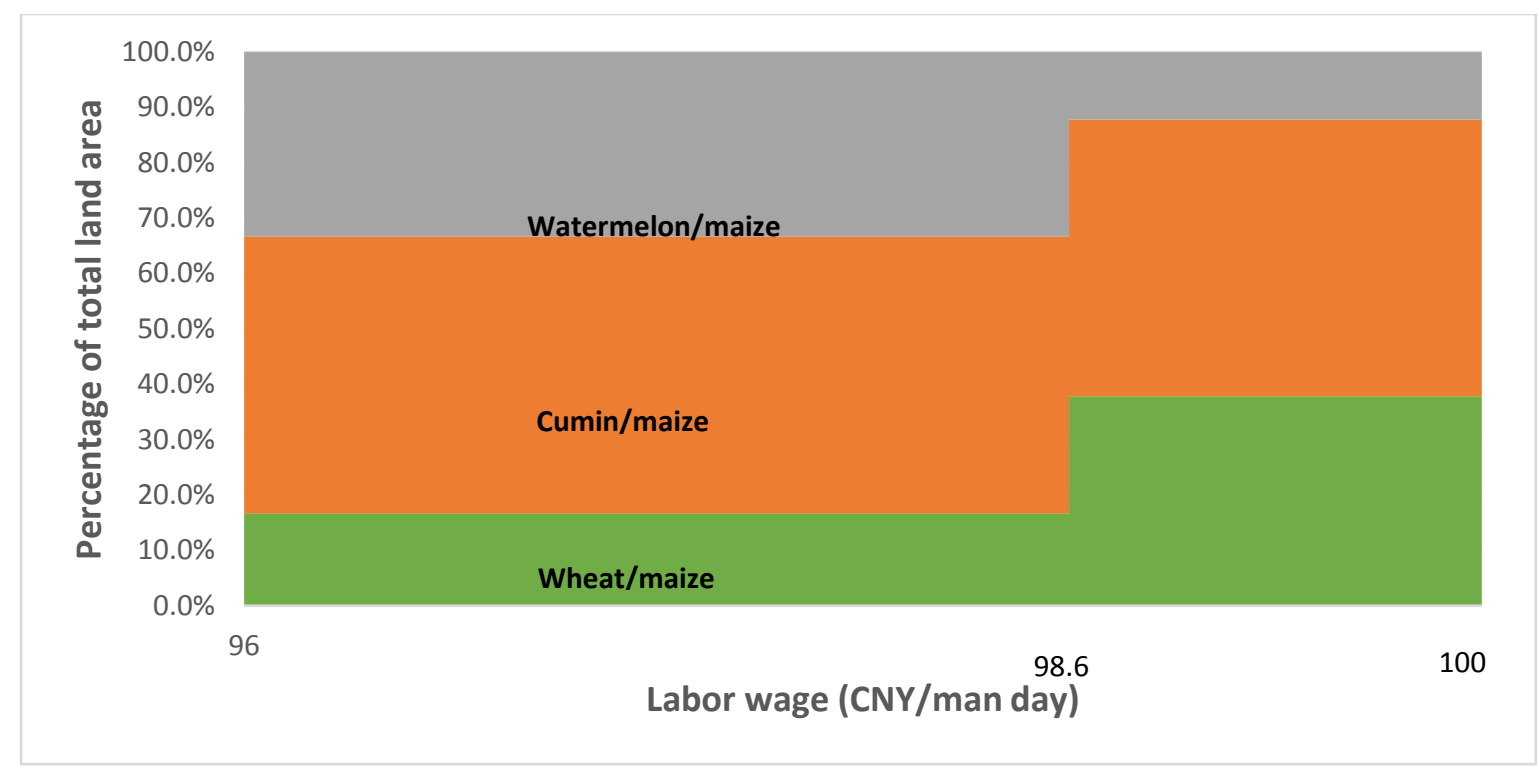

Figure 5.6 Labor wage and optimal crop plan (Sensitivity analysis 3, off-farm employment Level 1).

Note: When the labor wage exceeds $100 \mathrm{CNY} / \mathrm{man}$ day, the optimal crop plan does not change as compared to the plan obtained for $100 \mathrm{CNY} / \mathrm{man}$ day.

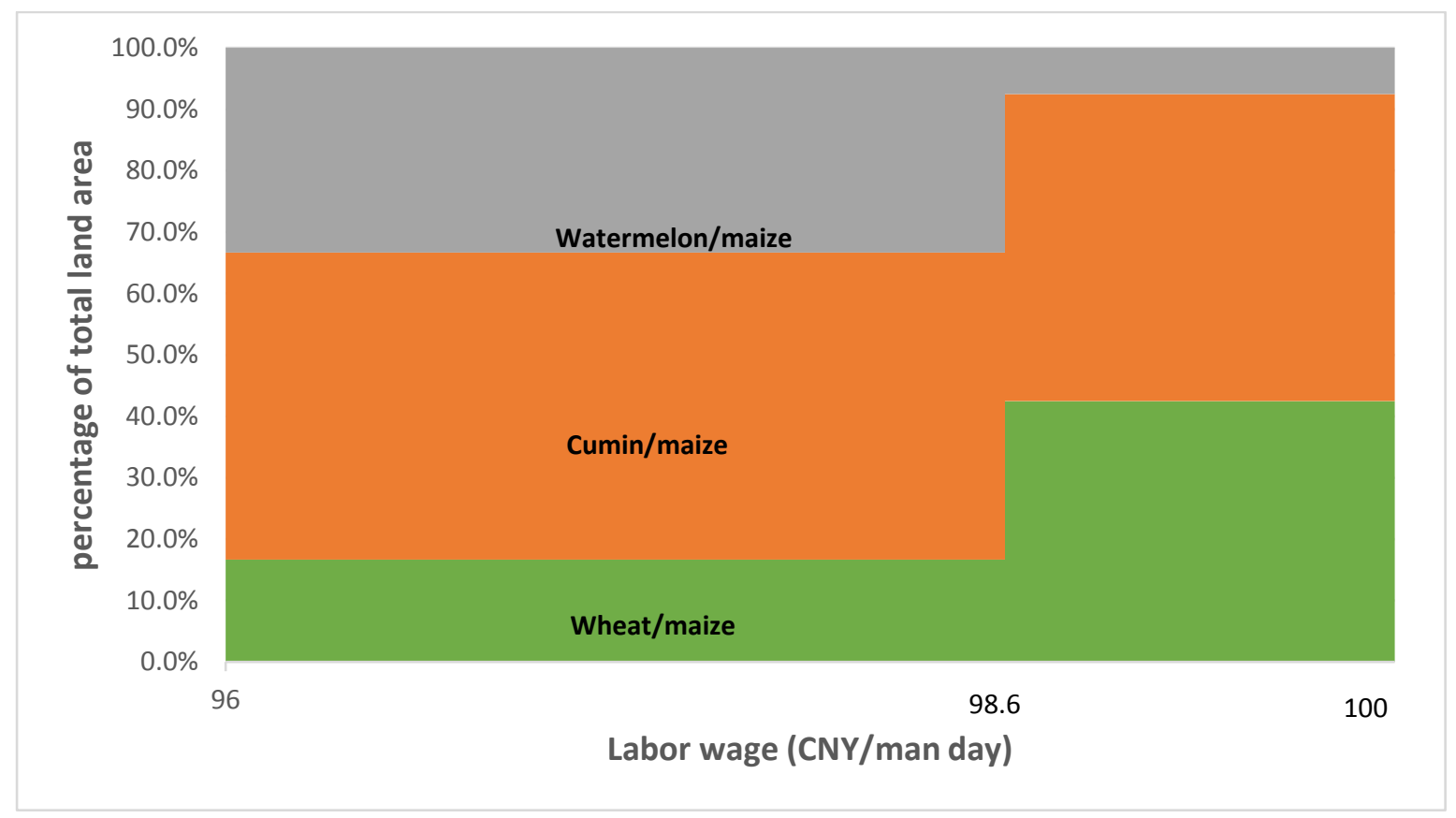

Figure 5.7 Labor wage and optimal crop plan (Sensitivity analysis 3, off-farm employment Level 2).

Note: When the labor wage exceeds $100 \mathrm{CNY} / \mathrm{man}$ day, the optimal crop plan does not change as compared to the plan obtained for $100 \mathrm{CNY} / \mathrm{man}$ day. 
Labor in June is a binding constraint for the optimal crop plan. In off-farm employment levels 1 and 2, wheat/maize becomes more profitable than seed watermelon/maize using hired labor when the wage exceeds 98.6 CNY/day. From this wage onwards no hired labor is used anymore. Part of the land, namely $12.2 \%$ for off-farm employment level 1 and $7.5 \%$ for offfarm employment level 2, can still be used for seed watermelon/maize using only family labor. Cumin/maize generates more profit and requires less labor than wheat/maize, but cannot exceed $50 \%$ of the land due to rotation requirements. Hence, in the optimal solution, wheat/maize replaces the share of the land that was previously planted with seed watermelon/maize.

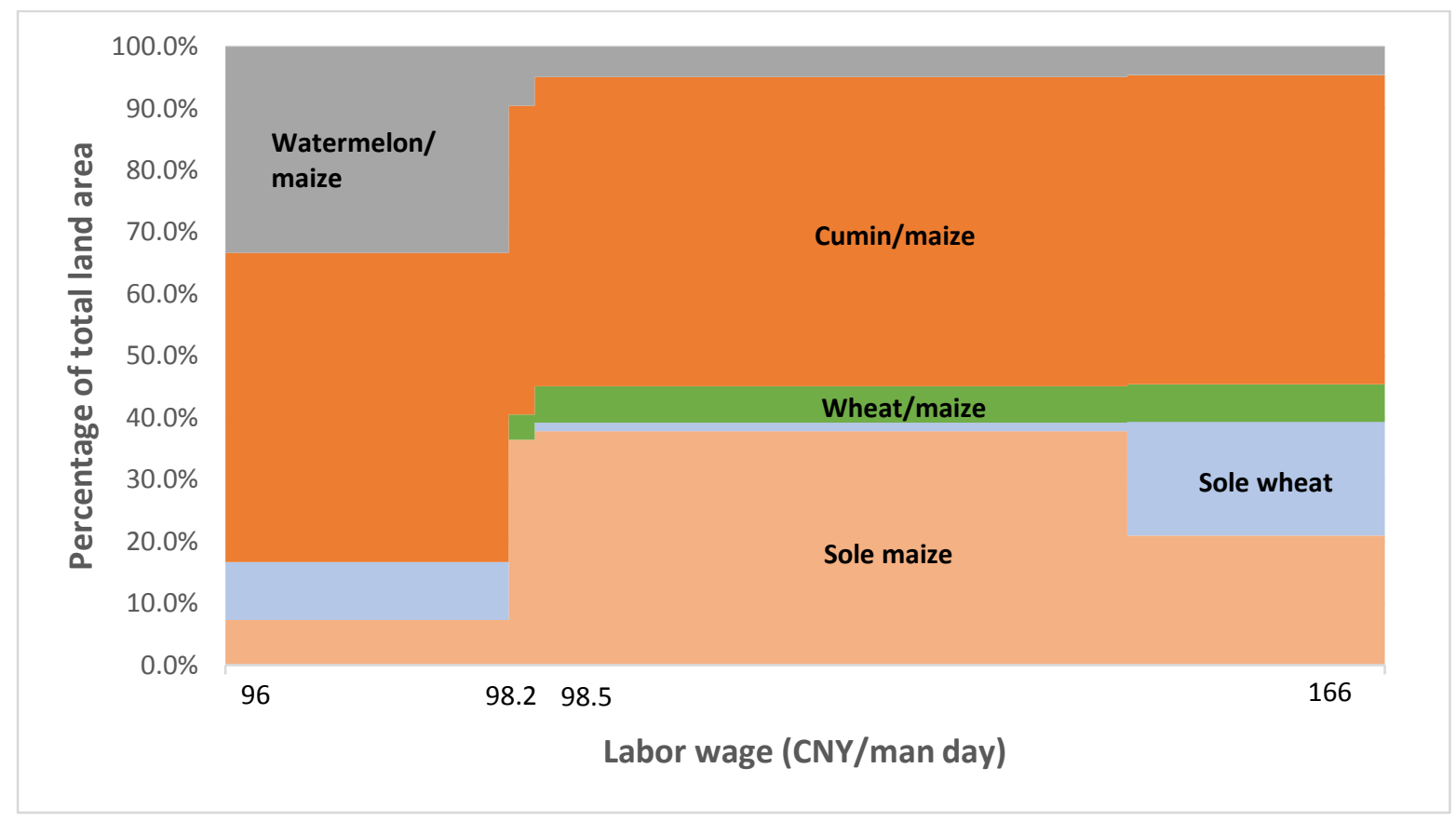

Figure 5.8 Labor wage and optimal crop plan (Sensitivity analysis 3, off-farm employment Level 3)

The optimal crop plan becomes more diversified when family labor availability becomes lower. For off-farm employment level 3, binding constraints hold for labor in April, May and June. As we can see from comparing Figure 5.8 with Figure 5.7, sole wheat replaces 
wheat/maize intercropping for wages between 96 - 98.2 CNY/day when off-farm employment increases from level 2 to 3. Sole wheat requires less labor than wheat/maize intercropping, in particular in April, May and June, and returns from wheat/maize cannot cover the cost of hired labor in these three months under off-farm employment level 3. The use of hired labor in seed watermelon/maize declines when the wage rate exceeds $85.2 \mathrm{CNY} /$ day and becomes zero at a wage rate higher than 98.5 CNY/day. Sole maize and sole wheat are included in the optimal crop plan because these sole crops require less labor. Half of the land is again planted with cumin/maize at all wage rates, because it generates a relatively high profit and requires relatively little labor during the period April - June.

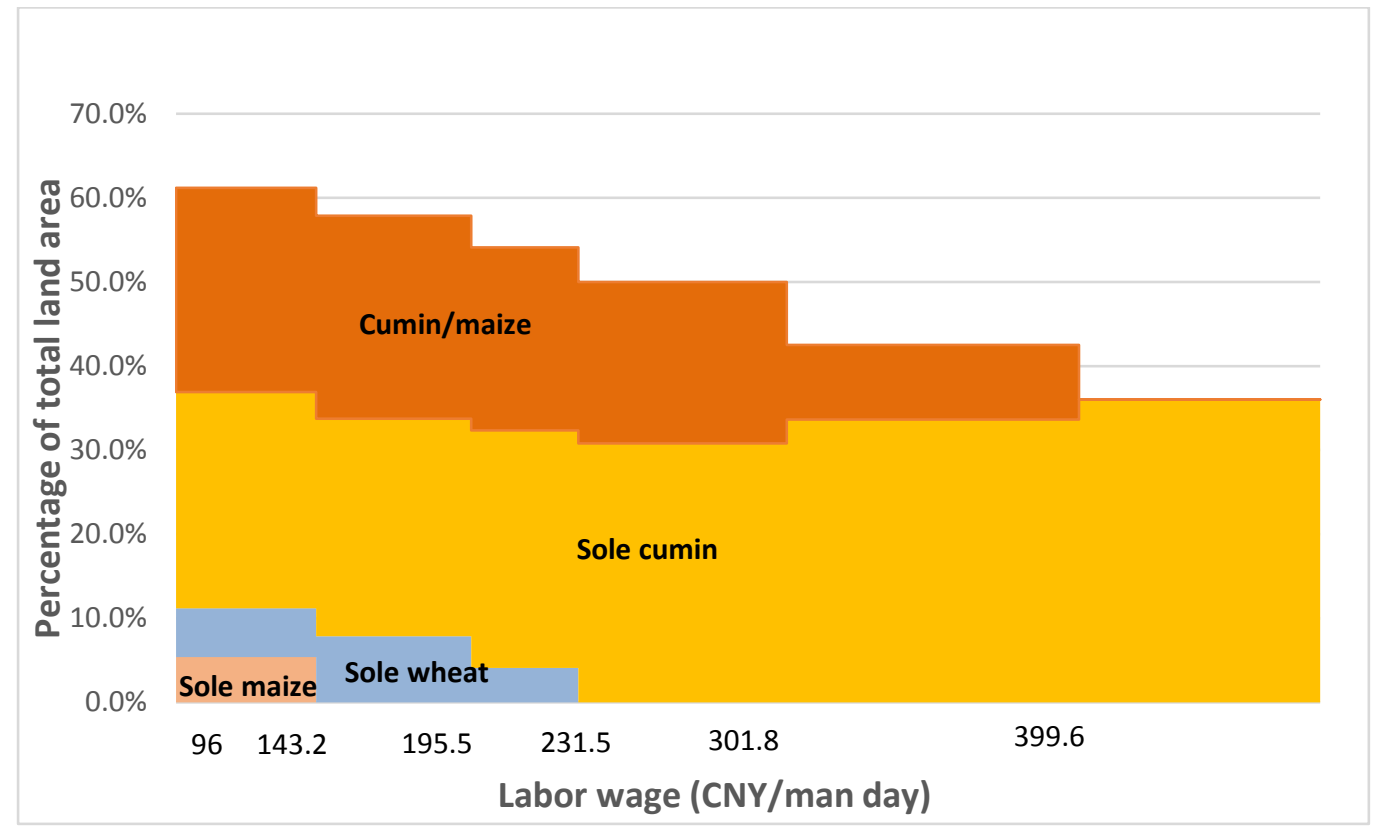

Figure 5.9 Labor wage and optimal crop plan (Sensitivity analysis 3, off-farm employment Level 4)

When off-farm employment equals four times its baseline level, little family labor is left for working on-farm (see two bottom rows in Table 5.2). Hence hired labor needs to be used for almost all on-farm activities. In the optimal solution for the baseline wage level, $50 \%$ of the land is still planted with cumin (see Fig. 5.9). But to save labor costs, more than half of that is 
planted with sole cumin instead of the intercrop. When the wage rate increases, cumin/maize is more and more replaced by sole cumin. The other two intercrops do not enter the optimal land use plan at this off-farm employment level, because their gross margins are negative when little or no family labor can be used. Instead, some small areas are planted with sole wheat and sole maize (up to a wage rate of $231.5 \mathrm{CNY} /$ day). A large share of the land $-40 \%$ at the baseline wage - is left idle due to the high costs of hiring labor. Its share increases with rising labor wages.

It can be concluded from Fig. 5.6 - 5.9 that cumin/maize is less sensitive to changing labor wages than seed watermelon/maize and wheat/maize at different levels of on-farm labor availability, because cumin/maize requires less labor than the other two intercrops. Unless availability of family labor for farming becomes extremely limited, i.e. no labor is available during a few months (April, May and June) in the growing season, intercropping will remain part of the optimal land use plan.

Figure 5.10 shows the gross margins for different wage rates under each of the four off-farm employment levels. At off-farm employment levels 1 and 2, no hired labor is used when the wage rate exceeds 98.6 CNY/day. Hence, the gross margin slightly declines between 96 98.6 CNY/day, and does not change at wage rates exceeding that level. The same holds for a wage rate exceeding 98.2 CNY/day under off-farm employment level 3. When almost all labor used in the village farms consists of hired labor (off-farm level 4), the gross margin shows a rapid decline with increasing wage rates as expected. 


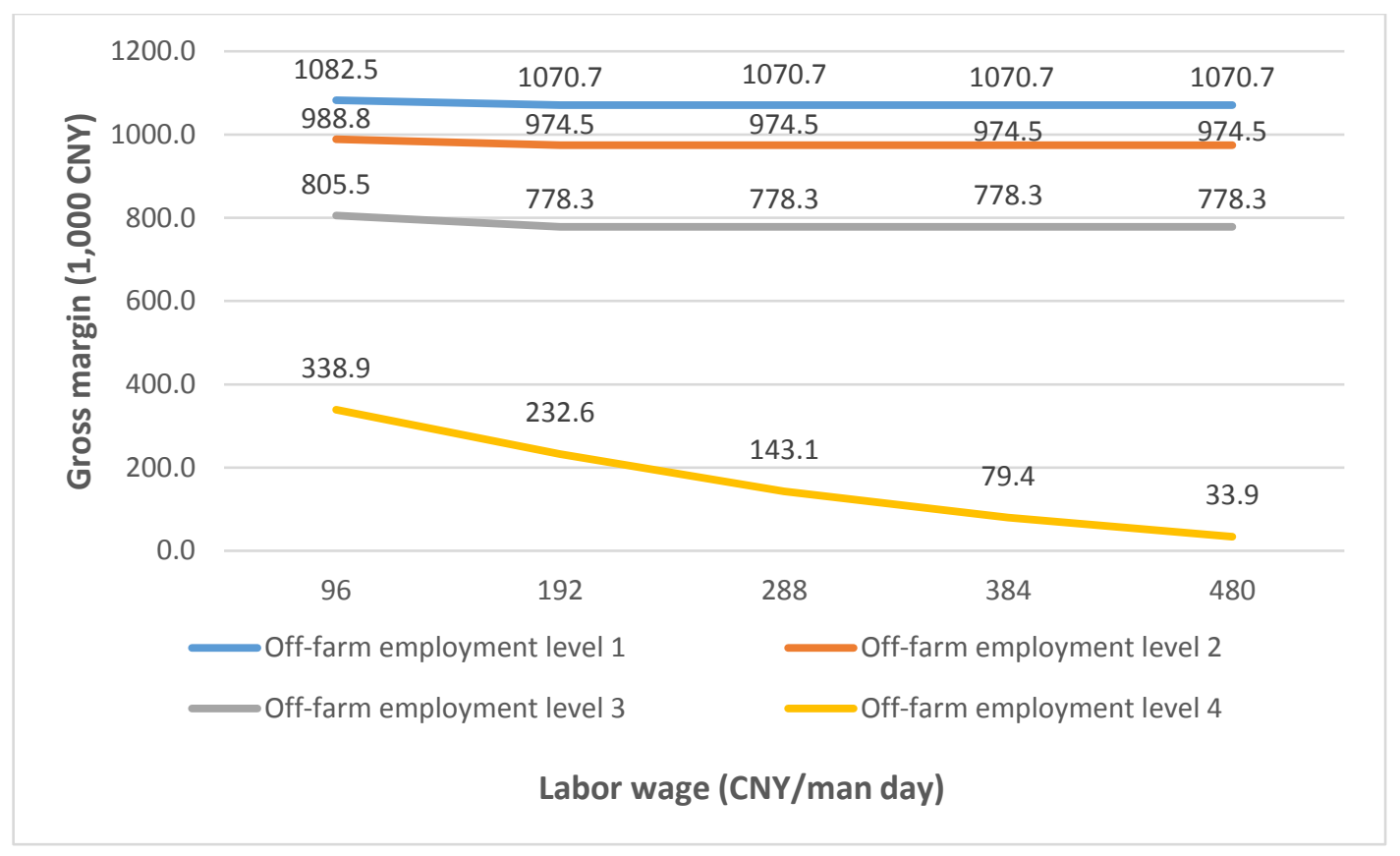

Figure 5.10 Labor wage and gross margin at 4 levels of off-farm employment (Sensitivity analysis 3 )

Scenario 2 intends to explore the future of intercropping under possible future developments, i.e. the water quota set at $640 \mathrm{~m}^{3} / \mathrm{mu}$, the maize price $20 \%$ lower than the baseline, and the labor wage twice its baseline value and off-farm employment is the same at the baseline. The results are presented and compared with Scenario 1 Baseline in Table 5.5. No hired labor is used in the optimal land use plan. Land used for seed watermelon/maize intercropping with hired labor in $\mathrm{S} 1$ is now planted with the wheat/maize intercrop. The gross margin from wheat/maize is still higher than that of sole cotton and sole wheat when the maize price is $20 \%$ lower than the baseline. These results show that in particular the rising labor wage plays an important role in the future use of intercropping. 
Table 5.5 Optimal crop plan of Scenario 2 (and Scenario 1 Baseline)

\begin{tabular}{lrr}
\hline Scenario & S1 Baseline (2013) & S2 \\
\hline Optimal cropping plan (mu) & & \\
$\quad$ Cotton & & \\
Sole maize & & \\
Sole wheat & & 253 \\
Sole cumin & & 327 \\
Sole watermelon (seed) & 109 & 73 \\
Wheat/maize intercropping & 327 & 1,298 \\
Cumin/maize intercropping & 218 & 356 \\
Seed watermelon/maize & & 942 \\
$\quad$ intercropping & 1,873 & 400,399 \\
Total revenue (1,000 CNY) & 791 & 0 \\
Total cost (1,000 CNY) & 1,082 \\
Total gross margin (1,000 CNY) & 395,634 & \\
Total water use (m $\left.{ }^{3}\right)$ & 4,469 & \\
Total hired labor (man day) & & \\
\hline
\end{tabular}




\subsubsection{Uncertainty analysis on the value of LER}

The impact of using lower values of LERs than the ones obtained in our fieldwork are explored in Figure 5.11. All land is used for intercropping until LERs become 18\% lower than the baseline, although a switch from seed watermelon/maize to wheat/maize takes place at $3 \%$ lower levels. Intercropping disappears when the LER is $27 \%$ lower than in baseline scenario (Fig. 5.11). The LER thus strongly affects the optimal crop plan.

The implications of lower LERs for the gross margin are shown in Figure 5.12. Gross margin steadily declines with lower LER values up to $27 \%$ lower LERs. From that point onwards, intercropping is no longer part of the optimal land use plan (and the total gross margin remains at a $46.3 \%$ lower level as compared to the estimated values of the LER).

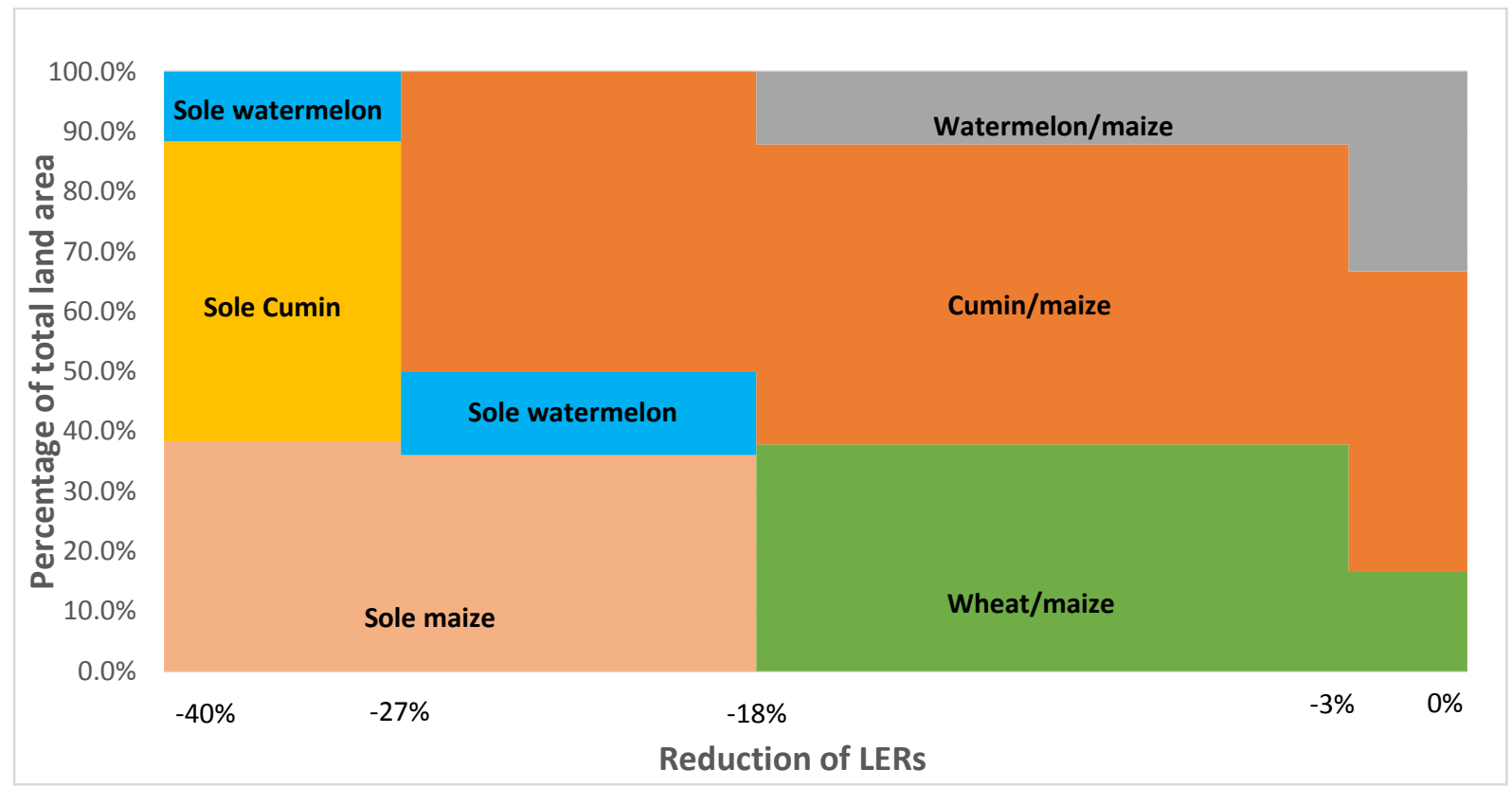

Figure 5.11 Levels of LERs and crop plan 


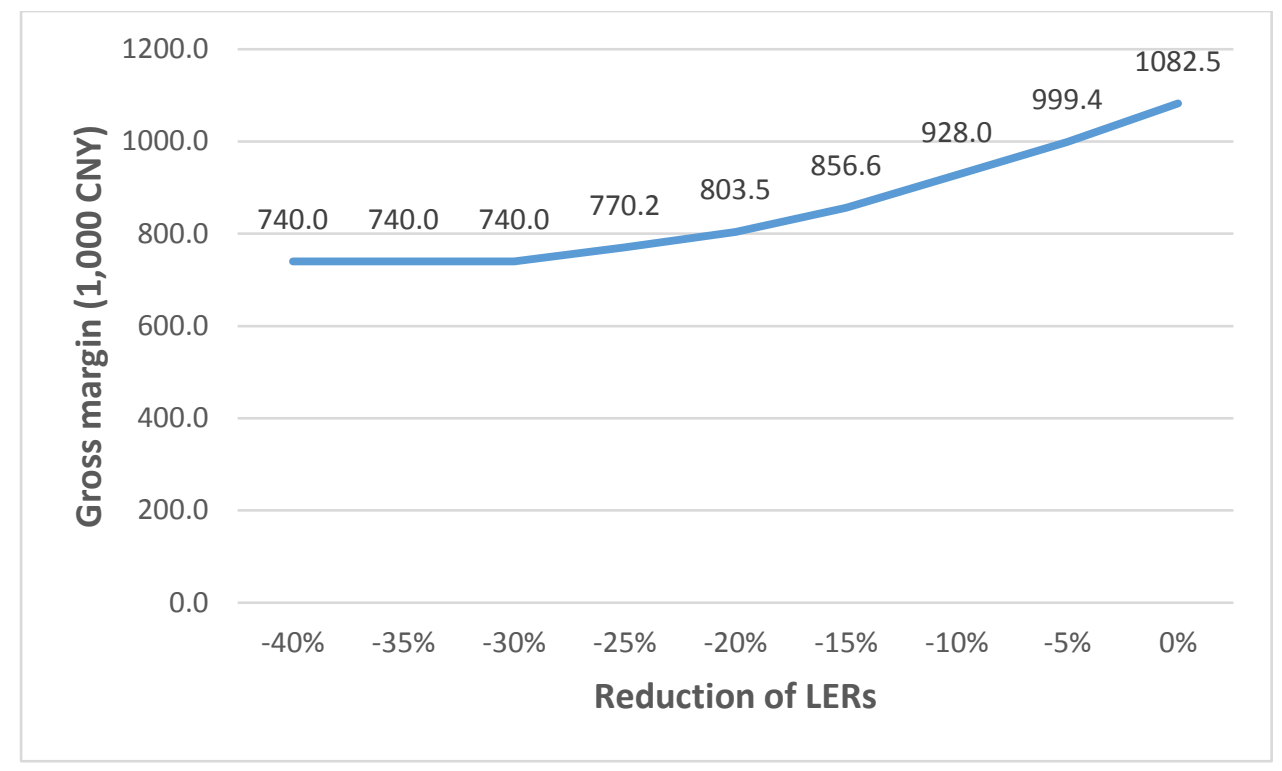

Figure 5.12 Levels of LERs and gross margin

\subsection{Discussion}

This study aimed at exploring the effects of growing water and labor scarcity and declining maize prices on the share of intercropping in the optimal land use system and associated agricultural income levels in a typical irrigated farming system in northwest China.

Firstly, we find that crop choices in baseline scenario ( 3 crops) are less diversified than the actual situation ( 8 crops) in 2013. This discrepancy may be in part due to not accounting for risk attitudes of farmers. The model assumed that the farmers in the typical village have maximization of gross margins as their only objective. In the real world, farmers often try to avoid risk. For instance, cumin is a risky crop because harvest may fail when there is too much rainfall. Even though cumin/maize offer superior returns, farmers may still include crops with stable yield but low or moderate return (e.g. wheat) to hedge against the risks of adverse weather. This is consistent with the findings from Shi et al., (2014), who found that farm households in the Heihe river basin prefer to plant disease-, drought- and cold-resistant 
crops (varieties) instead of crops with higher expected net returns but with larger uncertainties, as farmers seem more sensitive to potential yield and income losses than to potential gains.

Secondly, we find that intercropping is replaced by more drought-resistant sole crops when water quota are reduced, which is line with what happened in practice in Zhangye during the past decade (see introduction) and in Wuwei (another oasis in the Hexi Corridor) since 2000 (Mao et al., 2012).

Thirdly, we find that maize price plays a crucial role in the optimal use of land. A lower price of maize, i.c. $50 \%$ lower than the baseline in 2013 , will drive the conventional intercrop wheat/maize - out of existence; if the maize price declines more, i.c. $70 \%$ lower than the baseline in 2013, cumin/maize will be replaced in the optimal plan by sole cumin. These results are in line with our expectation that the maize price will have an important influence on the popularity of intercropping, because most intercropping systems are based on maize as one of the component crops of the mixture in China (Hong et al., 2017).

Fourthly, we find that the use of intercropping is negatively influenced by rising labor wages in combination with increasing off-farm labor employment. In the calculations we treated labor wage and off-farm labor employment as independent variables. However, in reality labor wages and off-farm labor employment will most probably be strongly related as an increase in the demand for labor in the Chinese economy will at the same time lead to higher labor wages and increasing labor migration away from rural areas.

We further find that the value of LER has a major influence on the inclusion of intercropping in the optimal crop plan. Intercropping dominates the land use when it shows great advantage over sole cropping, but when the mean value of LERs is $27 \%$ points lower than the baseline, the intercropping yield advantage is insufficient to offset the additional costs. This result is 
consistent with findings of Feike et al., (2012) who opined that high land use efficiency is the primary reason for Chinese farmers to use intercropping in the North China Plain. The high levels of LERs used in the baseline may be attributed to farmers using the relatively better parcels to cultivate intercropping as it usually provide them good return (Source: personal communication with local people). If sole crops can be applied in all sorts of quality parcels, the yield of sole crops is expected to increase accordingly. Thus, the income reduction results from switching from intercrops to sole crops may be overestimated.

Finally, we find that agricultural incomes are more sensitive to water scarcity than to maize price. The total agricultural incomes decreases rapidly with water quota less than $600 \mathrm{~m}^{3} / \mathrm{mu}$.

\subsection{Conclusion}

Intercropping is generally considered to contribute to higher yields and higher resource use efficiency, while counteracting resource degradation. This study developed a mathematical programming model at village level to analyze the effects of growing water and labor scarcity and declining maize prices on the share of intercropping in optimal cropping plan and associated agricultural income levels in Gaotai county, Gansu, northwest China.

The results show that the share of land under intercropping in the optimal land use is shrinking with the growing scarcity of water, with a declining maize price, and with increasing off-farm employment in combination with higher labor wages. With regard to the effects on agricultural incomes, increasing water scarcity has more negative impact than declining maize prices, while increases in hired labor wages have a strong negative impact only when on-farm labor become really scarce. 
These crop choice changes may have some important consequences. Firstly, the decreasing use of intercropping may make it difficult to realize the national goals that maintain the selfsufficiency for food through improving land use efficiency (Zuo et al., 2014). Secondly, it also has large negative impact on the agricultural incomes, which may make it more difficult to reach the goals of enhancing farmers' income and narrowing the rural-urban income disparity. These indirect effects of reducing water quota and lowering maize prices, through reduced using of intercropping, are generally overlooked in making decisions on these policies. Thus, policies aiming at water saving need to take into account the possible reduction of agricultural income, because agriculture in this region relies heavily on irrigation.

Agricultural production is an activity that entails risks (Hardaker, 2004), and intercropping is often considered to reduce risk of crop failure and enhance yield stability (Raseduzzaman and Jensen, 2017). Future research in this field may benefit from including the risks in the model, e.g. impose risk indicator in the objective function or regard risk as one of the objectives. 


\section{Acknowledgements}

The authors gratefully acknowledge advice from Lizhen Zhang in China Agricultural University on irrigation water inputs and crop outputs of intercropping systems, and also thank staff in Luocheng Water Management Bureau, Gaotai county, Zhangye city, for providing us information on water policy and prices of inputs. This research was funded by the China Scholarship Council (CSC, grant number: 201206300117) and the Key Sino-Dutch Joint Research Project of NSFC (Grant number: 31210103906). 


\section{References}

Bao, C., \& Fang, C. (2007). Water Resources Constraint Force on Urbanization in Water Deficient Regions: A Case Study of the Hexi Corridor, Arid Area of Nw China. Ecological Economics, 62(3), 508-517.

Chai, Q., Qin, A., Gan, Y., \& Yu, A. (2014). Higher Yield and Lower Carbon Emission by Intercropping Maize with Rape, Pea, and Wheat in Arid Irrigation Areas. Agronomy for Sustainable Development, 34(2), 535-543.

Chen, Y., Zhang, D., Sun, Y., Liu, X., Wang, N., \& Savenije, H.H.G. (2005). Water Demand Management: A Case Study of the Heihe River Basin in China. Physics and Chemistry of the Earth, Parts $A / B / C, 30(6), 408-419$. doi: https://doi.org/10.1016/i.pce.2005.06.019

Cong, W., Hoffland, E., Li, L., Six, J., Sun, J., Bao, X., et al. (2015). Intercropping Enhances Soil Carbon and Nitrogen. Global Change Biology, 21(4), 1715-1726.

Feike, T., Doluschitz, R., Chen, Q., Graeff-Hönninger, S., \& Claupein, W. (2012). How to Overcome the Slow Death of Intercropping in the North China Plain. Sustainability, $4(10), 2550-2565$.

Gale, H.F. (2013). Growth and Evolution in China's Agricultural Support Policies Economic Research Report No. 153. Washington, D.C.: Economic Research Service, U.S. Department of Agriculture

Gansu Bureau of Statistics. (2014). Gansu Statistical Yearbook Beijing: China Statistics Press. Gou, F., van Ittersum, M.K., Simon, E., Leffelaar, P.A., van der Putten, P.E.L., Zhang, L., et al. (2017). Intercropping Wheat and Maize Increases Total Radiation Interception and Wheat Rue but Lowers Maize Rue. European Journal of Agronomy, 84(Supplement C), 125-139. doi: https://doi.org/10.1016/i.eja.2016.10.014

Gou, F., Yin, W., Hong, Y., van der Werf, W., Chai, Q., Heerink, N., et al. (2017). On Yield Gaps and Yield Gains in Intercropping: Opportunities for Increasing Grain Production in Northwest China. Agricultural Systems, 151, 96-105.

Hardaker, J.B. (2004). Coping with Risk in Agriculture. Wallingford, UK: CABI.

Hong, Y., Heerink, N., Jin, S., Berentsen, P., Zhang, L., \& van der Werf, W. (2017). Intercropping and Agricultural in China-Current State and Trends. Agriculture Ecosystems \& Environment, 244, 52-61. 
Horwith, B. (1985). A Role for Intercropping in Modern Agriculture. Bioscience, 35(5), 286291.

Huang, J., \& Yang, G. (2017). Understanding Recent Challenges and New Food Policy in China. Global Food Security, 12(Supplement C), 119-126. doi: https://doi.org/10.1016/i.gfs.2016.10.002

Li, L., Sun, J., Zhang, F., Guo, T., Bao, X., Smith, F.A., et al. (2006). Root Distribution and Interactions between Intercropped Species. Oecologia, 147(2), 280-290.

Li, W., Li, L., Sun, J., Guo, T., Zhang, F., Bao, X., et al. (2005). Effects of Intercropping and Nitrogen Application on Nitrate Present in the Profile of an Orthic Anthrosol in Northwest China. Agriculture, Ecosystems \& Environment, 105(3), 483-491.

Lichtfouse, E. (2009). Sustainable Agriculture Reviews: Climate Change, Intercropping, Pest Control and Beneficial Microorganisms (Vol. 2). Dordrecht Springer Netherlands.

Lithourgidis, A., Dordas, C., Damalas, C., \& Vlachostergios, D. (2011). Annual Intercrops: An Alternative Pathway for Sustainable Agriculture. Australian journal of crop science, 5(4), 396-410.

Mao, L., Zhang, L., Li, W., van der Werf, W., Sun, J., Spiertz, H., et al. (2012). Yield Advantage and Water Saving in Maize/Pea Intercrop. Field Crops Research, 138, 11-20.

Mao, L., Zhang, L., Zhang, S., Evers, J.B., van der Werf, W., Wang, J., et al. (2015). Resource Use Efficiency, Ecological Intensification and Sustainability of Intercropping Systems. Journal of Integrative Agriculture, 14(8), 1542-1550. doi: https://doi.org/10.1016/S2095-3119(15)61039-5

Mead, R., \& Willey, R. (1980). The Concept of a 'Land Equivalent Ratio'and Advantages in Yields from Intercropping. Experimental Agriculture, 16(3), 217-228.

Raseduzzaman, M., \& Jensen, E.S. (2017). Does Intercropping Enhance Yield Stability in Arable Crop Production? A Meta-Analysis. European Journal of Agronomy, 91, 25-33.

Shi, M., Wang, X., Yang, H., \& Wang, T. (2014). Pricing or Quota? A Solution to Water Scarcity in Oasis Regions in China: A Case Study in the Heihe River Basin. Sustainability, 6(11), 7601-7620.

Sun, T., Wang, J., Huang, Q., \& Li, Y. (2016). Assessment of Water Rights and Irrigation Pricing Reforms in Heihe River Basin in China. Water, 8(8), 333.

Vandermeer, J.H. (1989). The Ecology of Intercropping. Cambridge: Cambridge University Press. 
Wang, H.H., Wang, Y., \& Delgado, M.S. (2014). The Transition to Modern Agriculture: Contract Farming in Developing Economies. American Journal of Agricultural Economics, 96(5), 1257-1271.

Wang, Y., Xiao, H.-I., \& Wang, R.-f. (2009). Water Scarcity and Water Use in Economic Systems in Zhangye City, Northwestern China. Water Resources Management, 23(13), 2655-2668.

Wang, Z., Zhao, X., Wu, P., He, J., Chen, X., Gao, Y., et al. (2015). Radiation Interception and Utilization by Wheat/Maize Strip Intercropping Systems. Agricultural and Forest Meteorology, 204, 58-66. doi: 10.1016/j.agrformet.2015.02.004

Xu, W. (2017, 12-1). Country to Expand Corn Ethanol Amid Garin Surplus. China Daily. Yang, C., Chai, Q., \& Huang, G. (2010). Root Distribution and Yield Responses of Wheat/Maize Intercropping to Alternate Irrigation in the Arid Areas of Northwest China. Plant Soil Environ, 56(6), 253-262.

Yu, Y., Stomph, T.-J., Makowski, D., \& van der Werf, W. (2015). Temporal Niche Differentiation Increases the Land Equivalent Ratio of Annual Intercrops: A MetaAnalysis. Field Crops Research, 184, 133-144.

Zhang, F., \& Li, L. (2003). Using Competitive and Facilitative Interactions in Intercropping Systems Enhances Crop Productivity and Nutrient-Use Efficiency. Plant and Soil, 248(1-2), 305-312.

Zhang, J. (2007). Barriers to Water Markets in the Heihe River Basin in Northwest China. Agricultural Water Management, 87(1), 32-40.

Zhang, J., \& Zhang, F. (2008). Mutual Monitoring in a Tradable Water Rights System: A Case Study of Zhangye City in Northwest China. Agricultural Water Management, 95(3), 331-338. doi: https://doi.org/10.1016/i.agwat.2007.10.016

Zhang, J., Zhang, F., Zhang, L., \& Wang, W. (2009). Transaction Costs in Water Markets in the Heihe River Basin in Northwest China. International Journal of Water Resources Development, 25(1), 95-105.

Zhang, L., Van der Werf, W., Bastiaans, L., Zhang, S., Li, B., \& Spiertz, J. (2008). Light Interception and Utilization in Relay Intercrops of Wheat and Cotton. Field Crops Research, 107(1), 29-42. 
Zhang, L., Zhu, X., Heerink, N., \& Shi, X. (2014). Does Output Market Development Affect Irrigation Water Institutions? Insights from a Case Study in Northern China. Agricultural Water Management, 131, 70-78.

Zhang, Y., \& Xue, B. (2016). Research on Impact of Adjustment of Water Price on Agricultural Planting Structure and Water Resources Utilization Efficiency - a Case Study of Water-Saving Society Pilot of Zhangye City. Resource Development \& Market, 32(6), 679-683. (in Chinese).

Zhou, D., Wang, X., \& Shi, M. (2016). Human Driving Forces of Oasis Expansion in Northwestern China During the Last Decade-a Case Study of the Heihe River Basin. Land Degradation \& Development, 28, 412-420.

Zhou, Q., Wu, F., \& Zhang, Q. (2015). Is Irrigation Water Price an Effective Leverage for Water Management? An Empirical Study in the Middle Reaches of the Heihe River Basin. Physics and Chemistry of the Earth, Parts A/B/C, 89-90(Supplement C), 25-32. doi: https://doi.org/10.1016/i.pce.2015.09.002

Zuo, L., Wang, X., Zhang, Z., Zhao, X., Liu, F., Yi, L., et al. (2014). Developing Grain Production Policy in Terms of Multiple Cropping Systems in China. Land Use Policy, 40, 140-146. 


\section{Chapter 6}

\section{Discussion and conclusions}




\section{Discussion and conclusions}

\subsection{Introduction}

China has nearly achieved (grain) self-sufficiency in recent years (NBSC, 2016; Huang and Yang, 2017), but increased food production has come at the expense of the environment and sustainable development (Lu et al., 2015). Agricultural production in China today faces a scarcity of land and water resources, while the costs of food production have increased due to rising rural wages. Intercropping, with its high land-use efficiency and agro-ecological advantages may play an important role in a future agriculture that aims to maintain national food security via sustainable utilization of natural resources. Much research on intercropping has been carried out from an eco-physiological perspective in China in recent decades (Li et al., 2007; Mao et al., 2012; Gou et al., 2017). However, a socio-economic analysis is critically needed to obtain more insight into why farmers adopt intercropping or not and why they shift from one production system to another. This study tries to fill this gap in the existing literature. Its overarching aim is to obtain a better understanding of farmers' decisions on intercropping in China. In order to reach that aim, four separate but related research questions are addressed in four different chapters.

In order to get more insight into the importance of intercropping in China at the moment, this study first estimates the current state and trends of intercropping in China based on data collected in six different provinces. The resulting estimates provide the first systematically collected evidence of the prevalence of intercropping in China. After that this study uses data collected for a specific region in northwest China to investigate the contribution of intercropping to the technical efficiency of small-scale farming, to examine socio-economic factors influencing the adoption of intercropping, and to explore the future of intercropping under changing conditions. Insights obtained from this case study are expected to be relevant 
for ongoing agricultural and natural resource policies in the region, e.g. policies focusing on (irrigation) water-savings and farm scale enlargement. Some of its novel insights may also prove useful for regions with similar agro-climatic and socio-economic conditions that make intercropping a viable option in China and other developing countries.

This chapter aims to present and discuss major findings derived from the research chapters of the thesis and suggests possible policy implications. In addition, the limitations of this study and some suggestions for future research are discussed. The remainder of the chapter is structured as follows. Section 6.2 recaps the findings of the study. Section 6.3 discusses the contribution to the available literature. Section 6.4 presents policy implications. Finally, section 6.5 concludes by presenting limitations of the study and providing some suggestions for further study.

\subsection{Synthesis of findings}

\subsubsection{Intercropping is practiced on a small proportion of the land but has not declined in recent years}

Intercropping has been practiced for thousands of years in China (Knörzer et al., 2009). While it is frequently claimed that intercropping remains popular in Chinese agriculture, there are also reports that it is in decline. Little quantitative evidence is available on the prevalence of intercropping. Based on systematic data collection and analyses, the study finds that intercropping was practiced on approximately three percent of the arable land in a total of 63 surveyed villages in six provinces in China. These estimates are much lower than most 'guesstimates' in previous studies since the 1990s (see chapter 2, Table A2). The study also finds that the use of intercropping did not significantly change between 2009 and 2014. There 
was a large variety of species combinations in intercropping. Another noteworthy finding is that most intercropping systems were based on a cereal (e.g. maize) as one of the component crops of the mixture.

\subsubsection{Intercropping improves the technical efficiency of small-scale farming}

Intercropping generally results in a high efficiency of land use (Yu et al., 2015; Martin-Guay et al., 2018), but it is still an open question as to whether it contributes to a higher efficiency of the full set of inputs that is used to produce agricultural output. Applying technical efficiency analysis to a farm household data set collected in one specific county in northwest China, this study finds that increasing the share of land under intercropping has a significant positive effect on the overall technical efficiency of farming. This finding supports the notion that intercropping is a relatively efficient land-use practice in the case study area.

\subsubsection{Socio-economic factors related to the use of intercropping}

In chapter 4, we use data from the same case study in northwest China to investigate the factors at the farm household level affecting the adoption of the relay intercropping system prevalent in many parts of northwest China. This study finds that farm size and availability of irrigation water are important determinants of the use of intercropping. Larger farms devote absolutely more, but proportionally less, land to intercropping as compared to small farms. Availability of irrigation water affects adoption of relatively water-intensive intercrops, but does not play a significant role in the adoption of intercrops with a higher water use efficiency like cumin/maize. The results further reveal that availability of labor and of agricultural machinery does not negatively affect the area under intercropping, while the presence of small 
sowing machines that can be used for multiple crops has a significant positive effect on the adoption of one novel intercropping - cumin/maize. Risk avoidance, an advantage of intercropping that is often mentioned, does not play a significant role here.

\subsubsection{Water and labor scarcity and maize price stress intercropping and its future}

The explorative analysis of the future of intercropping under changing conditions finds that gross income would be maximized if all land would be assigned to intercropping systems when water constraints are absent and price levels and labor availability of 2013 prevail. Intercropping is replaced by more drought-resistant crops - sole cumin and sole cotton when water becomes scarce and maize price declines substantially. Moreover, increases in hired labor wages have a strong negative impact on intercropping only when on-farm labor becomes scarce.

\subsection{Scientific relevance}

\subsubsection{Does agricultural mechanization reduce the use of intercropping?}

Traditionally, intercropping is regarded as a practice in the developing world where farmers have limited access to agricultural machinery and chemicals (Horwith, 1985). For developed countries, it was reported that intercropping was commonly used in the United States and Europe before 1940 (Kass, 1978; Andersen, 2005). After that, the widespread production and operation of machines, together with the availability of relatively cheap synthetic fertilizers and pesticides discouraged intercropping in modern industrialized agriculture in the US and Europe (Horwith, 1985; Machado, 2009). The reason behind this is that little mechanization for intercropping has been developed, and intercropping therefore remains labor-intensive. 
Large machinery has been designed for monocultures and is widely available on the market and extensively used. Available studies seemed to support this role of mechanization in the decline of intercropping. For instance, Feike et al. (2012) found that the increase in machine use, together with other production factors (labor, land and capital) jointly has had a strong negative influence on the use of intercropping in the last 15 years in the North China Plain.

The explorative village-level empirical analysis in chapter 2, that found a significant negative association between intercropping and agricultural machinery, and the more rigorous household-level intercropping adoption analysis in chapter 4 , that found a significant positive impact of machinery use on intercropping, provide more insights into the role of agricultural machinery in the (dis)adoption of intercropping. It should be noted that chapters 2 and 4 address results obtained in different agro-climatic regions where different intercropping systems are used. Chapter 2 covers results obtained for 63 villages in six different provinces, representing a large diversity of intercropping systems, while chapter 4 focuses on relay strip intercropping in three villages located in one county in semi-arid northwest China. The availability of large machinery designed for monocultures, like combine harvesters, encourage farmers to abandon traditional intercropping systems that cannot make use of those machines. Yet, some intercropping systems with a high land use and technical efficiency, like the relay intercropping systems that we examined in this study, may benefit from the availability of small machinery, like sowing machines, that may be used for both mono- and intercropping systems. Hence, our findings show that access to agricultural machinery does not always drive farmers away from intercropping. Depending on agro-climatic conditions and available machinery types, it may even encourage the adoption of (more modern) intercropping techniques. This finding is consistent with those of studies recommending to promote strip intercropping systems that can make use of standard agricultural machinery in China (Feike et al., 2012; Wu and $\mathrm{Wu}, 2014)$. 


\subsubsection{Is intercropping feasible when farm size increases?}

Intercropping is often practiced by small-scale traditional farmers aiming to sustain food production and diversify income (Lithourgidis et al., 2011; Li et al., 2013; Huang et al., 2015). The findings in chapter 3 reveal that there is a non-linear relation between land size and technical efficiency of farming; small-scale farms can improve technical efficiency through expanding their land size. Given that the land rental market has rapidly developed in contemporary China, smallholders may rent more land to satisfy their demand for expansion. However, we find that technical efficiency decreases after a certain farm size has been reached. In our case it is highest for farms with a size of ca. $22 \mathrm{mu}$ (i.e. 1.5 hectares). In chapter 4, we also find that larger farms have smaller land shares under the wheat/maize intercrop that is traditionally grown in the region as compared to small farms. But the land shares grown with two relatively new intercropping types (cumin/maize and seed watermelon/maize) do not significantly differ between large and small farms. Hence, farm scale enlargement in case study region in northwest China is expected to reduce the area grown with the traditional intercrop but will probably not have much impact on the land shares grown under the relatively new intercrops. In other words, the agro-ecological and economic gains of growing intercrops may still be realised under the current farm scale enlargement policy in China, provided sufficient attention is paid to the development of new intercropping types that are adapted to (ongoing and expected future) changes in resource availability and market conditions. 


\subsubsection{Labor in intercropping}

Intercrops are more complicated to manage than monoculture, and mechanization is often not available for intercrops. Therefore, intercropping is usually labor-intensive (Lithourgidis et al., 2011; Feike et al., 2012). Empirical studies show that labor use is often higher in intercrops than in sole crops (Mkamilo, 2004; Huang et al., 2015). The estimated relationship between labor availability and the use of intercropping varies between chapter 2, chapter 4 and chapter 5. Findings for 63 villages in chapter 2 show that the share of land under intercropping is positively associated with labor availability, while it does not play a significant role in the use of intercropping in three villages in northwest China according to the findings presented in chapter 4. A possible explanation for this discrepancy is that labor is not (yet) a limiting factor in the case study region in northwest China due to a relatively low participation rate in off-farm work (and a relatively high profitability of agricultural work). The fact that intercropping has been partially mechanized in the three villages in northwest China (see previous sub-section) is another factor that may explain the limited role of labor availability in this region.

In chapter 5, the impact of off-farm employment by family members on the use of intercropping was explored for the case study region in northwest China. At current off-farm employment levels (and current wage levels), and even at off-farm employment levels that are twice as large, maximum farm income is obtained by planting all land with intercrops. Only at off-farm employment levels that are $3-4$ times as high as current levels, the share of land planted with intercrops would need to decline in order to generate maximum income. These findings provide further support for the limited impact of (family) labor availability on the use of intercropping in the region where we did the field research. 


\subsection{Policy implications}

Measures taken to deal with the rapidly growing resource scarcity in northwest China may impact the use of intercropping, which in turn affects rural household welfare and natural resource quality. Findings in chapter 4 show that the traditional wheat/maize intercrop and the novel seed watermelon/maize intercrop become less popular when availability of irrigation water declines. Only intercrops requiring relatively little water, like cumin/maize in the research area, are likely to remain unaffected. Findings in chapter 5 further show that the wheat/maize intercrop will be abandoned when water becomes scarce (i.e. less than 500 $\mathrm{m}^{3} / \mathrm{mu}$ ) in the case study region. Moreover, even cumin/maize will be replaced by sole cumin when water becomes even more scarce (i.e. less than $200 \mathrm{~m}^{3} / \mathrm{mu}$ ). Given that seed watermelon/maize and cumin/maize are the most profitable crops, and that wheat/maize intercropping also generates positive income, the decreasing use of these intercrops may make it difficult to realize the goals of enhancing farmers' income and reducing rural-urban income disparities. Thus, policies aimed at saving irrigation water should carefully consider their potential negative effects on reaching other policy goals, including rural poverty reduction and promoting environmental sustainability.

Ensuring national food security and a higher growth of farmers' income are the central goals of China's recent agricultural and food policy (Huang and Yang, 2017). In 2016, the Chinese government announced new reforms that stopped the price support and the Temporary Storage Program (TSP) for maize. Findings from chapter 5 show that intercropping will become less important for optimal land use in the study region when maize prices decline. Maize-based intercrops often have higher profit margins than sole crops. Given that most intercropping systems are based on maize as one of the component crops of the mixture in China, the declining maize prices are expected to have a negative effect on farmers' income, especially for those regions with fewer off-farm employment opportunities. Policies aimed at 
further liberalizing maize markets in China should preferable take these (unintended) sideeffects of the decline in maize-based intercropping systems and its associated effects on farm incomes and natural resource use into account.

Farm scale enlargement has received much attention in agricultural policy making in China in recent years. Increasing farm sizes up to levels where rural households can make a living by working (almost) full-time on their own farms is considered an important path towards agricultural modernization. In chapter 4, we found that larger farms have smaller land shares under the wheat/maize intercrop that is traditionally grown in the region as compared to small farms. But the land shares grown with two relatively new, and most profitable, intercropping types do not significantly differ between large and small farms. Hence, part of the income and environmental benefits of intercropping as compared to monocrops can be maintained under the current farm scale enlargement policy, provided appropriate options for mechanization are either available (as in the case study region) or are being developed.

\subsection{Limitations and recommendations for future study}

The research presented in this thesis is a first attempt to improve the understanding of the use of intercropping and its future in China, from a socio-economic perspective. It may, however, require more research than the four studies presented in this thesis before understanding this practice well. In this section, I will point out a number of limitations of the study and discuss possibilities for future research.

Firstly, the small sample size in chapter 2 . Six out of the 30 provinces is a relatively small sample size as one main purpose of this research is to present an overview of the prevalence of intercropping in China. Some provinces and regions where specific intercropping practices 
are reported to be popular were not included in this study. For future study, data collection on intercropping systems could be integrated into existing data collection systems for rural China, such as the Rural Fixed Observation Point Survey (RFOPS), to obtain a broader regional coverage and thereby further improve the quality of the estimates.

Secondly, the explorative regressions analyses on factors related to the use of intercropping in chapter 2. Data limitations prohibit the inclusion of agro-ecological conditions, and cultural or other factors that may play an important role in household decisions on the adoption of monoculture vs. intercropping systems. Thus, systematic data collection of intercropping systems would allow a more rigorous examination of the socio-economic, agro-ecological and other factors underlying the use of intercropping systems by, for example, clustering the results based on different classes or regions.

Thirdly, the studies presented in chapter 3 to chapter 5 focus on a relatively small region (Gaotai county, Gansu Province, northwest China) where relay (strip) intercropping is an important practice. The results derived from the study may be hard to generalize to the whole of China, while they may be relevant in particular for regions that have similar agro-climatic conditions. Future research may compare different intercropping types, e.g. strip intercropping vs. row intercropping vs. mixed intercropping, to examine if the results presented in the studies still hold. The theoretical framework presented in chapter 4 may still serve as a basis for empirically examining the adoption of other types of intercropping.

Last but not least, in chapter 3, I investigate the contribution of intercropping to the overall technical efficiency of small-scale farming using multiple-factor technical efficiency analysis. An interesting avenue for future research could be to explore the relation between the use of intercropping and single-factor (input) technical efficiency. That is, whether increasing the share of land under intercropping will have a negative or positive effect on single-factor 
technical efficiency of inputs like irrigation water or fertilizer. This may produce useful insights into which factor(s) are responsible for technical efficiency (or inefficiency) of farming, and may also reveal the contribution of intercropping to single-factor use efficiency. 


\section{References}

Andersen, M.K. (2005). Competition and Complementarity in Annual Intercrops-the Role of Plant Available Nutrients. Samfundslitteraur Grafik, Frederiksberg, Copenhagen, Copenhagen, Denmark.

Feike, T., Doluschitz, R., Chen, Q., Graeff-Hönninger, S., \& Claupein, W. (2012). How to Overcome the Slow Death of Intercropping in the North China Plain. Sustainability, 4(10), 2550-2565.

Gou, F., Yin, W., Hong, Y., van der Werf, W., Chai, Q., Heerink, N., et al. (2017). On Yield Gaps and Yield Gains in Intercropping: Opportunities for Increasing Grain Production in Northwest China. Agricultural Systems, 151, 96-105.

Horwith, B. (1985). A Role for Intercropping in Modern Agriculture. Bioscience, 35(5), 286291.

Huang, C., Liu, Q., Heerink, N., Stomph, T., Li, B., Liu, R., et al. (2015). Economic Performance and Sustainability of a Novel Intercropping System on the North China Plain. PloS One, 10(8), e0135518.

Huang, J., \& Yang, G. (2017). Understanding Recent Challenges and New Food Policy in China. Global Food Security, 12(Supplement C), 119-126. doi: https://doi.org/10.1016/i.gfs.2016.10.002

Kass, D., C,L. (1978). Polyculture Cropping Systems : Review and Analysis. Ithaca, US: Cornell University.

Knörzer, H., Graeff-Hönninger, S., Guo, B., Wang, P., \& Claupein, W. (2009). The Rediscovery of Intercropping in China: A Traditional Cropping System for Future Chinese Agriculture - a Review. In E. Lichtfouse (Ed.), Climate Change, Intercropping, Pest Control and Beneficial, Microorganisms (pp. 13-44). Dordrecht: Springer Netherlands.

Li, L., Li, S., Sun, J., Zhou, L., Bao, X., Zhang, H., et al. (2007). Diversity Enhances Agricultural Productivity Via Rhizosphere Phosphorus Facilitation on Phosphorus-Deficient Soils. Proceedings of the National Academy of Sciences, USA, 104(27), 11192-11196.

Li, L., Zhang, L., \& Zhang, F. (2013). Crop Mixtures and the Mechanisms of Overyielding. In S. Levin (Ed.), Encyclopedia of Biodiversity (pp. 382-395). Waltham: Academic Press. 
Lithourgidis, A., Dordas, C., Damalas, C., \& Vlachostergios, D. (2011). Annual Intercrops: An Alternative Pathway for Sustainable Agriculture. Australian journal of crop science, 5(4), 396.

Lu, Y., Jenkins, A., Ferrier, R.C., Bailey, M., Gordon, I.J., Song, S., et al. (2015). Addressing China's Grand Challenge of Achieving Food Security While Ensuring Environmental Sustainability. Science Advances, 1(1), e1400039.

Machado, S. (2009). Does Intercropping Have a Role in Modern Agriculture? Journal of Soil and Water Conservation, 64(2), 55A-57A.

Mao, L., Zhang, L., Li, W., van der Werf, W., Sun, J., Spiertz, H., et al. (2012). Yield Advantage and Water Saving in Maize/Pea Intercrop. Field Crops Research, 138, 11-20.

Martin-Guay, M.-O., Paquette, A., Dupras, J., \& Rivest, D. (2018). The New Green Revolution: Sustainable Intensification of Agriculture by Intercropping. Science of the Total Environment, 615, 767-772.

Mkamilo, G.S. (2004). Maize-Sesame Intercropping in Southeast Tanzania : Farmers' Practices and Perceptions, and Intercrop Performance. Wageningen University [S.I.]. Retrieved from http://edepot.wur.nl/139849

NBSC. (2016). 11.03.2018, from http://www.stats.gov.cn/tjsi/sjid/201603/t20160304 1326842.html (in Chinese)

Wu, K., \& Wu, B. (2014). Potential Environmental Benefits of Intercropping Annual with Leguminous Perennial Crops in Chinese Agriculture. Agriculture, Ecosystems \& Environment, 188, 147-149.

Yu, Y., Stomph, T.-J., Makowski, D., \& van der Werf, W. (2015). Temporal Niche Differentiation Increases the Land Equivalent Ratio of Annual Intercrops: A MetaAnalysis. Field Crops Research, 184, 133-144. 


\section{Summary}

The continuing growth of the world population, together with urbanization and changing dietary preferences, places an increasing pressure on agricultural production. The intense competition for natural resources from other industries and deteriorating quality of land and water resources due to unsustainable use, make matters worse for agriculture. Nowadays, the development of more sustainable practices for intensification with while limited environmental repercussions is a worldwide concern. Intercropping is one of the potential cropping systems that may satisfy these objectives.

Intercropping is the simultaneous cultivation of two or more crop species in the same field. It has been practiced in China for thousands of years. In recent decades, researchers in several disciplines have shown increasing interest in intercropping systems, due to their potential to generate higher yields and counteract resource degradation. Much research on intercropping has been carried out from an eco-physiological perspective in China in recent decades. However, a socio-economic analysis is critically needed to obtain more insight into why farmers adopt intercropping or not and why they shift from one production system to another. This study tries to fill this gap in the existing literature. Its main aim is to obtain a better understanding of farmers' decisions on intercropping in China. In order to reach that aim, four separate but related research questions are formulated and analyzed in four individual research chapters. Firstly, what is the current state of intercropping, and what are the latest major trends of intercropping in China? Secondly, what is the contribution of intercropping to the technical efficiency of small-scale farming in northwest China? Thirdly, what are the socioeconomic factors that affect farmers using (relay) intercropping in northwest China? Lastly, what is the future of intercropping under changing socio-economic conditions in northwest 
China? That is, how will increasing labor and water scarcity and declining grain prices affect the inclusion of intercropping in farmers' land use decisions?

The information used for the empirical analyses comes from two distinct datasets. The first empirical study aims to present an overview of the current prevalence of intercropping, and its recent trends in China. A national survey dataset, namely 'Rural Fixed Observation Points Survey' dataset is used. For the other three empirical research studies (chapters 3, 4 and 5), data collected from a household survey in the Heihe River Basin, northwest China is used. The latter three studies focus on (relay) intercropping in small-scale farming, using a case study on household decision-making in Gaotai County, Gansu Province, northwest China.

Chapter 2 estimates the share of arable land under intercropping in 63 villages in six provinces in China in the years 2009 and 2014, based on systematic data collection. In addition, another mixed cultivation system - agroforestry, and its share of arable land, garden land, and forest land, are estimated. Results show that intercropping was practiced on approximately three percent of the arable land in the surveyed villages, while agroforestry was practiced on approximately one percent of the arable land and one percent of the area of plantation plus forest land. The use of both these systems did not significantly change between 2009 and 2014. An explorative village-level analysis of factors associated with mixed species cultivation practices (intercropping and agroforestry) reveals a significant positive association with labour availability, and a smaller, but mostly significant, negative association with agricultural machinery power. This chapter provides recent, systematically collected evidence on the prevalence of intercropping in China.

Chapter 3 investigates the effect of intercropping on the technical efficiency of farming under current conditions in northwest China. It provides empirical evidence about the contribution of intercropping to the effectiveness with which a given set of inputs is used to produce 
agricultural output. The empirical results show that technical efficiency scores are positively affected by the share of land assigned to intercropping. The results also give strong support to the view that intercropping is a comparatively efficient land use system in the case study area in northwest China.

Chapter 4 examines the impact of farm household assets and household characteristics like risk aversion on the adoption of traditional and new types of intercropping. The results show that natural assets (land and irrigation water) are important determinants of the use of intercropping, while human assets (including labor-land ratios) and financial assets do not have a significant effect. Neither do risk aversion perceptions of farm households play a significant role. Availability of machinery does not negatively affect the area under intercropping, but has a significant positive effect on the adoption of one novel intercrop type (cumin/maize). Findings of this study provide insights into the socio-economic determinants of the use of (relay) intercropping in northwest China. The developed theoretical framework in this chapter may be also applied to examine adoption of other types of intercropping (row intercropping and mixed intercropping) in other regions and countries.

Chapter 5 explores the effect of growing scarcity of water and labor resources and declining (maize) grain prices on the share of intercropping in the optimal cropping plan and on the associated agricultural income levels in an intercropping-dominated agricultural system in China. A mathematical programming model was developed to analyzed crop production for a model village in Gaotai county in the Hexi Corridor in northwest China, for given resources and economic conditions in 2013 and possible changes (scenarios) in the future. The model results indicate that optimal land use would entail that all land would be devoted to intercropping, in the absence of water constraints and at price levels and labor availability in 2013. Further findings show that sole cumin and sole cotton enter the optimal cropping plan when water becomes scarce and the maize price declines substantially, while increases in 
hired labor wages have a strong negative impact on intercropping when on-farm labor becomes scarce. All in all, water and labor scarcity and declining maize prices all affect negatively the potential use of intercropping in the future; among the aforementioned three factors, (rural) labor scarcity has the most negative impact on intercropping.

In chapter 6 I conclude the study by revisiting the key issues addressed in the introduction and discussing the major findings and its possible policy implications. Intercropping is practiced on a small but non-negligible proportion of China's arable land, and has not declined in recent years. Given its relatively high land use efficient, and its relatively high profit in the case study region in northwest China, intercropping will continue to provide pathways for the intensification of agricultural food production and to contribute to the growth of farmers' income in China. 


\section{Acknowledgements}

It is a long road, with joys, hesitations and difficulties, this is my $\mathrm{PhD}$ life. During the journey, many people have helped me in many ways. Here I express my sincere thanks to all of them.

To start with, I would like to thank my daily supervisors - Nico and Wopke, for their great supports, guidance and trusts. Nico and Wopke, you have been helped me in every aspect of my $\mathrm{PhD}$ training. You are always patient to help me to correct my writings, either a report or a manuscript, from the title to the last reference, from punctuations to tense. Also, you realized the different culture and background between Chinese and western students, and encouraged me to speak out my ideas and opinions, even though sometimes these are stupid and naïve. More importantly, you teach me how to think and work independently and manage time. Lizhen, the other member of the supervision team, he helped me a lot to shape my PhD study in the first two years. Also, he taught me how to communicate with my supervisors. I am also grateful to Paul for your suggestions and supports for my research and PhD study.

Then, I would like to thank my colleagues and secretaries. Prossy, Maria, Martha, Fausta and all the other fellow students, thanks for your teamwork for dealing with assignments and for discussions on ideas and models. My office roommates, Yan Wu, Jane, Mark, Yeshimebet and Judith, thanks for your supports and encouragements. I also want to thank Erwin and Maarten for organizing fantastic football matches. I always enjoy the time with all of football teammates and these moments are never forgettable.

Moreover, I was so lucky to meet friends who have contributed to make my PhD life more fruitful. These friends are, Min Liu, Li Meng, Zhao Zhou, Juan Zhang, Lei Chen, Lu Xiong, Keyang Li, Jin Zhang, Tian Yu, Zihan Nie, Chen Qian, Kai Wang, Minjie Chen, Fan Li, Guangcheng Ren, Changkun Guan, Jinghui Hao, Qianqian Shao, Yan Jin, Fang Gou and 
Yang Yu. I would never forget those days, altogether, we did workouts, went swimming and played basketball; and went for travelling, had parties, went for BBQ and picnic. I appreciate the time with all of you very much.

Lastly, I would like to thank my family, for their love and supports. The other special thanks go to my girlfriend, Wenzhao. Thanks so much for your love, understanding, encouragement and endurance. Without you I am afraid I cannot go through my PhD life, especially for those difficult moments. 


\section{Yu Hong}

Wageningen School of Social Sciences (WASS)

Completed Training and Supervision Plan

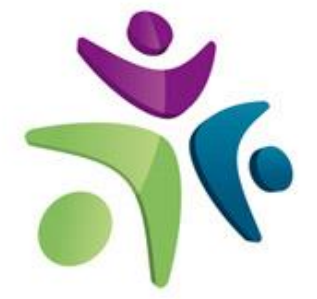

Wageningen School

of Social Sciences

\begin{tabular}{|c|c|c|c|}
\hline Name of the learning activity & Department/Institute & Year & ECTS* \\
\hline \multicolumn{4}{|l|}{ A) Project related competences } \\
\hline Rural Economic Analysis (AEP-31306) & WUR & 2013 & 6 \\
\hline $\begin{array}{l}\text { Advanced Agricultural Business Economics (BEC- } \\
\text { 30306) }\end{array}$ & WUR & 2013 & 6 \\
\hline Advanced Econometrics (AEP-60306) & WUR & 2013 & 6 \\
\hline $\begin{array}{l}\text { Quantitative Analysis of Land Use Systems (QUALUS) } \\
\text { (PPS-30306) }\end{array}$ & WUR & 2014 & 6 \\
\hline \multicolumn{4}{|l|}{ B) General research related competences } \\
\hline Research Methodology: From topic to proposal & WASS & 2013 & 4 \\
\hline WASS Introduction Course for new PhD candidates & WASS & 2013 & 1.2 \\
\hline Writing of the $\mathrm{PhD}$ research proposal & WUR & 2013 & 6 \\
\hline Project and Time Management & WGS & 2014 & 1.5 \\
\hline Techniques for Writing and Presenting a Scientific Paper & WGS & 2016 & 1.2 \\
\hline $\begin{array}{l}\text { 'Intercropping and Agroforestry in China - Current State } \\
\text { and Trends' }\end{array}$ & WASS PhD day & 2016 & 1 \\
\hline Scientific Writing & WGS & 2016 & 1.8 \\
\hline \multicolumn{4}{|c|}{ C) Career related competences/personal development } \\
\hline 'Intercropping in China - current state and trends' & $\begin{array}{l}\text { The International Workshop of } \\
\text { Intercropping, Xi'an, China }\end{array}$ & 2015 & 1 \\
\hline \multirow[t]{2}{*}{$\begin{array}{l}\text { 'The contribution of intercropping to the technical } \\
\text { efficiency of smallholder farming: a case study in } \\
\text { Gaotai, China' }\end{array}$} & $\begin{array}{l}\text { The Chinese Economists } \\
\text { Society (CES), annual meeting, } \\
\text { Shenzhen, China }\end{array}$ & 2016 & 1 \\
\hline & $\begin{array}{l}\text { The Chinese Agricultural } \\
\text { Economics Review (CAER) \& } \\
\text { International Food Policy } \\
\text { Research Institute (IFPRI), } \\
\text { annual meeting, Fuzhou, China }\end{array}$ & 2016 & \\
\hline
\end{tabular}

Total

42.7

*One credit according to ECTS is on average equivalent to 28 hours of study load. 


\section{Funding}

The research described in this thesis was financially supported by the China Scholarship

Council (CSC) and the Key Sino-Dutch Research Project of NSFC (grant number:

31210103906).

Financial support from the Development Economics Group, Wageningen University and the

Stichting Gilles Hondius Foundation for printing this thesis is gratefully acknowledged.

Cover design by Yu Hong

Printed by Proefschriftmaken 